UNIVERSIDADE DE SÃO PAULO

\title{
OS CONSÓRCIOS PÚBLICOS NO DIREITO BRASILEIRO
}

Dissertação de mestrado

Candidato: Ricardo Augusto Negrini

Orientadora: Professora Titular Maria Sylvia Zanella Di Pietro

FACULDADE DE DIREITO

SÃO PAULO

2009 
RICARDO AUGUSTO NEGRINI

\section{OS CONSÓRCIOS PÚBLICOS NO DIREITO BRASILEIRO}

Dissertação apresentada à Faculdade de Direito da Universidade de São Paulo para a obtenção do grau de Mestre em Direito.

Área de concentração: Direito do Estado Orientadora: Professora Titular Maria Sylvia Zanella Di Pietro

\section{SÃO PAULO}




\section{FOLHA DE APROVAÇÃO}

Candidato: Ricardo Augusto Negrini

Título: Os consórcios públicos no direito brasileiro

Dissertação apresentada à Faculdade de Direito da Universidade de São Paulo para obtenção do título de Mestre.

Área de concentração: Direito do Estado

Aprovado em:

Banca examinadora 


\section{AGRADECIMENTOS}

A realização de qualquer trabalho é tarefa tanto menos árdua quanto maiores sejam o apoio, o estímulo e a inspiração obtidos pelo empreendedor. É justamente por isso que se pode dizer, com toda a propriedade, que as pessoas que colaboram direta ou indiretamente para a consecução das nossas tarefas, mesmo que da maneira mais sutil, são verdadeiros co-autores da obra.

Mostra-se, portanto, não apenas conveniente, nem muito menos protocolar, mas indispensável agradecer a todos os que auxiliaram na elaboração desta dissertação de mestrado, nomeadamente a Professora Maria Sylvia Zanella Di Pietro, que, mesmo com os seus afazeres do magistério e da advocacia, encontrou tempo e disposição para oferecer todo o suporte de que um orientando necessita; os Professores Edmir Netto de Araújo e Fernando Dias Menezes de Almeida, pelas bem fundadas críticas e sugestões; Mario Luiz Bonsaglia, pelas lições sobre federalismo e pelo exemplo de acadêmico e procurador da República; minha família, em especial Nilde Maria Rotolo Negrini, minha mãe, que muito contribuiu na revisão, com a experiência de quem lecionou português por toda a vida; meu pai, Osvaldo Negrini Neto, pelo permanente incentivo, mesmo nos momentos mais desanimadores; e minha tia Eliana Rotolo, pelo inestimável auxílio com as complicadíssimas normas da ABNT.

Revela-se igualmente imprescindível agradecer a contribuição dos inúmeros colegas e amigos que, ao longo da empreitada, forneceram subsídios jurídicos, respostas para os mais variados problemas enfrentados, ou mesmo palavras de reconforto e encorajamento. Seria possível, em nome de todos eles, agradecer a Ricardo César Duarte, Rodrigo Octávio de Godoy Bueno Caldas Mesquita, Paulo Fernando Campana Filho, Júlia Prestes Chuffi Barros, Martina Elizabete Lessa Pio dos Santos, Renata Porto Adri, Juliana Bonacorsi de Palma e Camila Fasanella Brito da Cunha, sem prejuízo da homenagem a todos os demais que prestaram seu valioso auxílio.

E acima de tudo, agradeço a Deus. 


\section{RESUMO}

Como uma nova perspectiva da teoria federalista, o federalismo cooperativo opõe-se à clássica abordagem dualista, balanceando a tensão entre a autonomia dos entes federados e o mútuo auxílio. Nesse quadro, os consórcios públicos podem ser considerados o estágio final do processo de cooperação, fornecendo os instrumentos para possibilitar a gestão e a prestação conjunta de serviços públicos. O trabalho busca analisar o desenvolvimento de tais ajustes no direito brasileiro, especialmente após as recentes mudanças operadas no texto constitucional e levadas adiante pela Lei n. ${ }^{\circ}$ 11.107/05 (Lei de Consórcios Públicos), que resultaram no advento de um novo modelo contratual, concretizado numa pessoa jurídica intergovernamental. Os métodos de estudo envolvem as tarefas de indentificação das raízes históricas das formas de cooperação, investigação das atuais possibilidades dos consórcios e seus limites e, finalmente, detalhamento do funcionamento da gestão associada, incluindo a estrutura da pessoa interfederativa, seus poderes e regime jurídico. As conclusões apontam para a importância da utilização planejada dos consórcios públicos de modo a que se alcancem consideráveis ganhos econômicos e sociais, permitindo aos governos locais enfrentar problemas comuns que de outra maneira não seriam resolvidos, em matérias como saúde pública, educação e outros serviços públicos - e apenas serviços públicos, já que a legislação restringe as possíveis metas consorciais a esse específico conceito.

Palavras-chave: Consórcios públicos. Federalismo cooperativo. Gestão associada. Serviços públicos. 


\begin{abstract}
As a new perspective of the federalist theory, cooperative federalism opposes to the classic dualistic approach, balancing the conflict between states autonomy and mutual aid. Under this arrangement, intergovernmental agreements may be considered the final level of the cooperation process, providing the means to allow the joint management and deliver of public services. The paper aims to analyze these agreements development on brazilian law, especially after the recent changes enacted in the constitutional text and carried on by Law 11.107/05, which resulted in a new contractual model, materialized in an intergovernmental corporation. The study methods involve the tasks of identifying historical sources of cooperation forms, inquiring the agreements current possibilities and its limits and, finally, detailing the joint management functioning, including the corporation structure, powers and legal regime. The conclusions points to the importance of planned use of the cooperative agreements in order to reaching considerable economical and social gains, by allowing local governments to face common issues that otherwise would never be solved, in matters such as public health, education and other public services - and only public services, since the legislation restricts the agreements possible goals to this specific concept.
\end{abstract}

Keywords: Intergovernmental agreements. Cooperative federalism. Public service. 


\section{SUMÁRIO}

1. INTRODUÇÃ

2. FEDERALISMO COOPERATIVO …................................................................ 16

2.1. RAÍZES DO FEDERALISMO DE COOPERAÇÃO................................................ 16

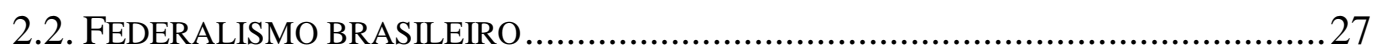

2.3. EVOLUÇÃO HISTÓRICA DO FEDERALISMO COOPERATIVO BRASILEIRO ..............34

3. A REESTRUTURAÇÃO DA ADMINISTRAÇÃO PÚBLICA ....................................50

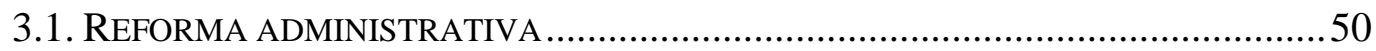

3.2. AdMINISTRAÇÃO PÚBLICA GERENCIAL........................................................ 52

3.3. OS ACORDOS ENTRE ENTES FEDERADOS (ASSOCIAÇÕES DE MUNICÍPIOS, CONVÊNIOS DE DELEGAÇÃO, CONVÊNIOS DE COOPERAÇÃO, CONSÓRCIOS) .........................57

4. DELINEAMENTO HISTÓRICO DOS CONSÓRCIOS PÚBLICOS ...........................66

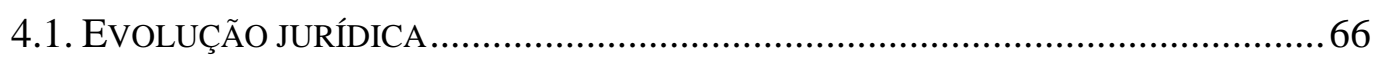

4.2. EXPERIÊNCIA BRASILEIRA DOS CONSÓRCIOS ADMINISTRATIVOS .................... 70

5. ATUAL REGRAMENTO JURÍDICO DOS CONSÓRCIOS PÚBLICOS ....................74

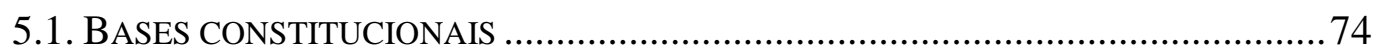

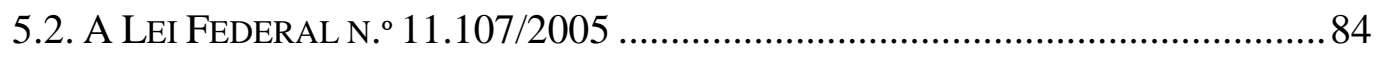

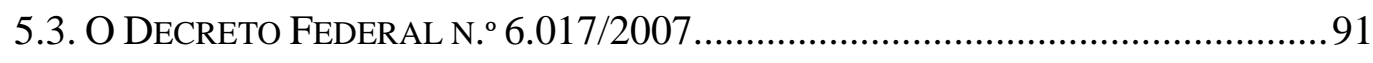

6. CONFIGURAÇÃO ATUAL DOS CONSÓRCIOS PÚBLICOS .................................94

6.1. NOÇÃO DE CONSÓRCIO PÚBLICO NA LEI N. ${ }^{\circ} 11.107 / 2005$............................ 94

6.1.1. Diferentes acepções da expressão “consórcio público”....................... 94

6.1.2. Natureza jurídica do ato de constituição dos consórcios públicos .......95

6.1.3. Natureza jurídica do consórcio público............................................. 106

6.1.3.1. A associação pública............................................................... 109

6.1.3.2. O consórcio com personalidade jurídica de direito privado -

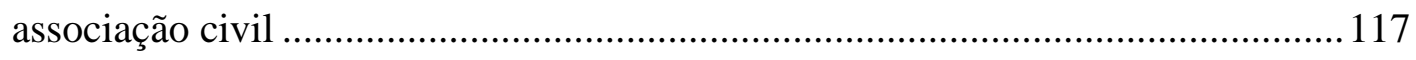

6.2. DiSTINÇÃO ENTRE A NOÇÃO ATUAL E A ANTERIOR DE CONSÓRCIO .................121 
6.3. O CONSÓRCIO PÚBLICO E FIGURAS SIMILARES NO DIREITO COMPARADO ...... 123

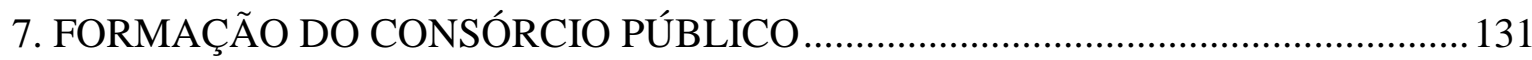

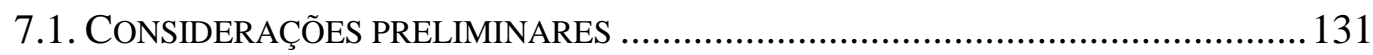

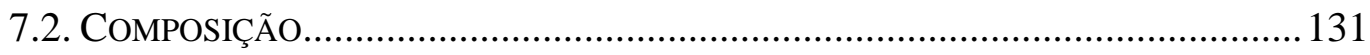

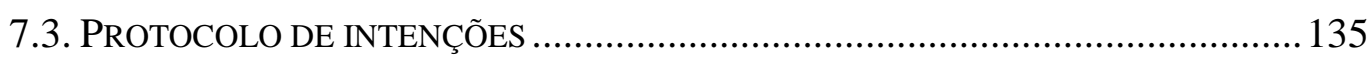

7.4. NECESSIDADE DE RATIFICAÇÃO LEGISLATIVA .......................................... 138

7.5. FORMALIZAÇÃO E PUBLICAÇÃO DO CONTRATO ........................................... 143

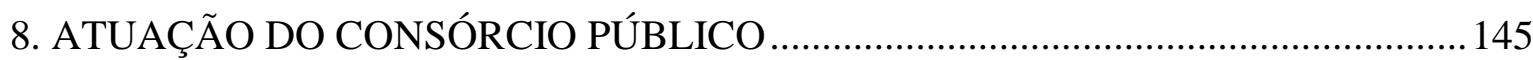

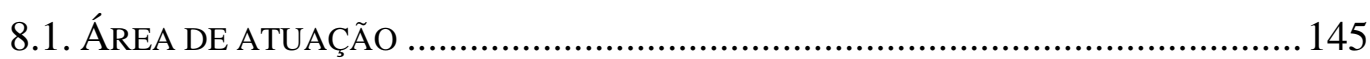

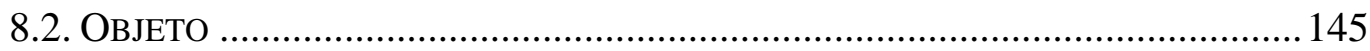

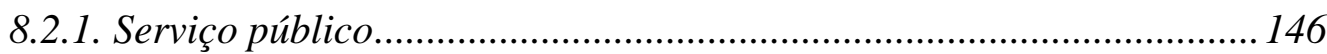

8.2.2. Titularidade e exercício das competências constitucionais................. 156

8.2.3. Possíveis objetivos dos consórcios ..................................................... 158

8.3. FORMAS DE PRESTAÇÃO DE SERVIÇO PÚBLICO ............................................ 162

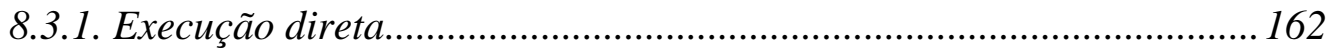

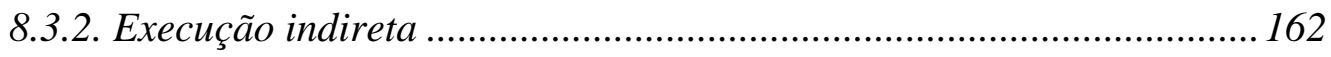

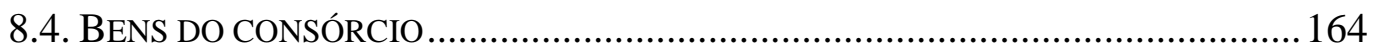

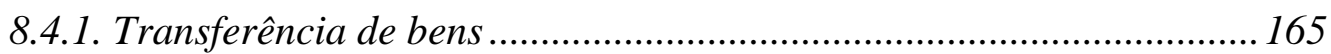

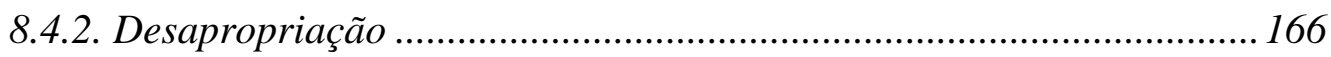

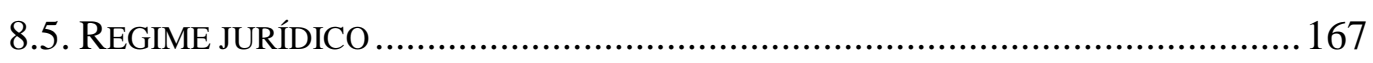

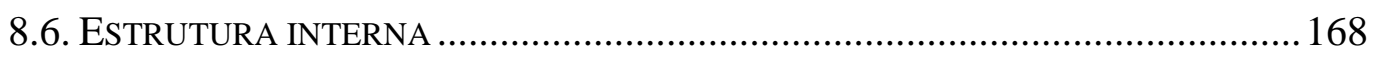

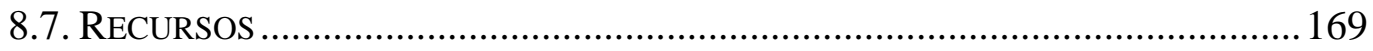

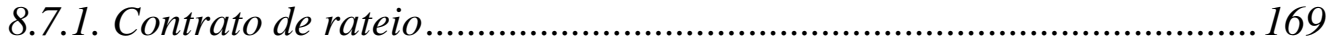

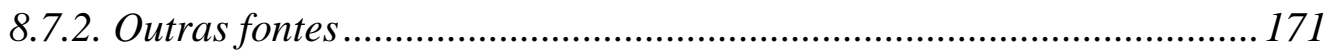

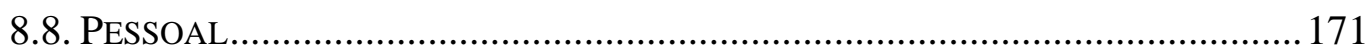

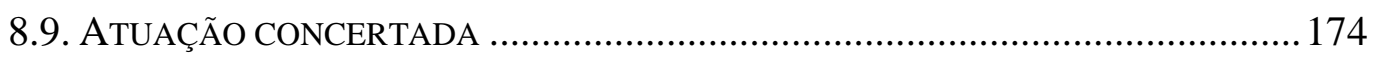

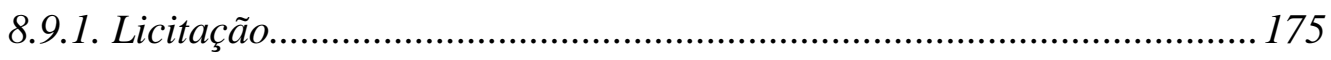

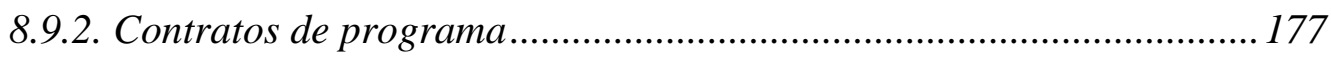

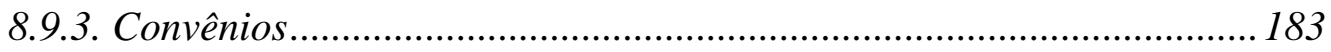

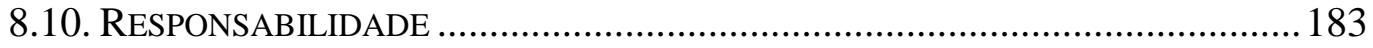

9. ALTERAÇÃO E EXTINÇÃO DO CONSÓRCIO PÚBLICO ....................................190 


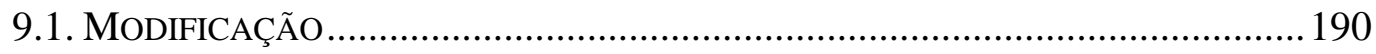

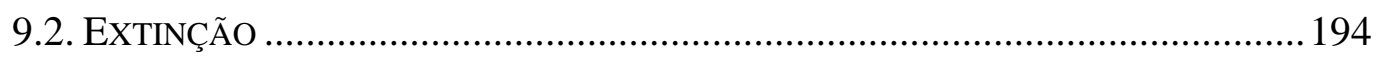

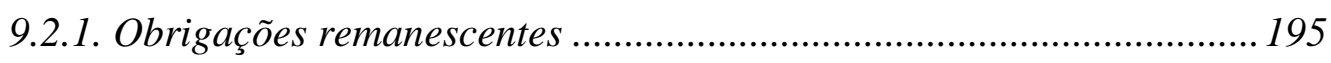

9.2.2. Subsistência dos contratos de programa ............................................. 196

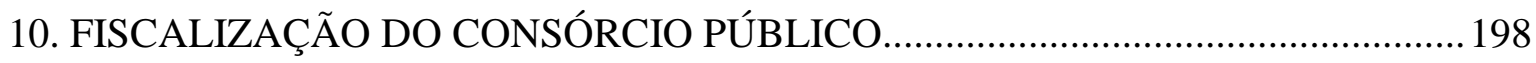

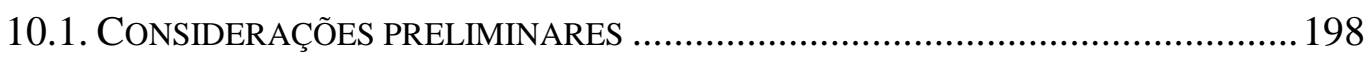

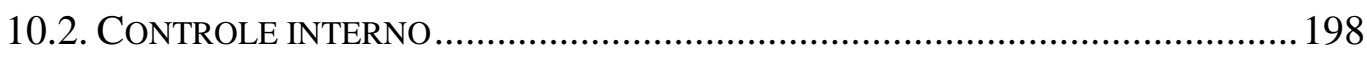

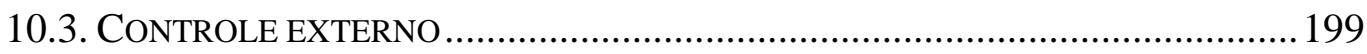

11. OS CONSÓRCIOS NA PRÁTICA DA ADMINISTRAÇÃO BRASILEIRA ............202

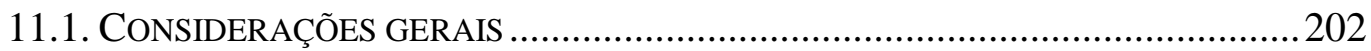

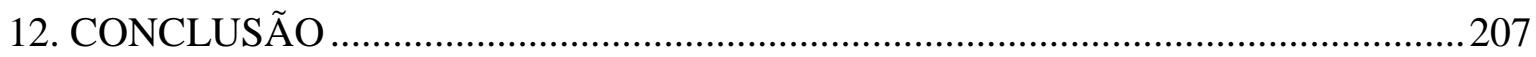

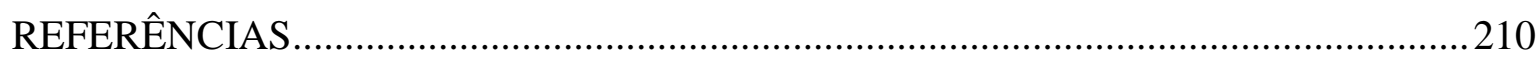




\section{INTRODUÇÃO}

$\mathrm{O}$ modelo de Estado que se vem desenhando nas últimas décadas, aliado às transformações na concepção das funções que o Poder Público deve desempenhar, resultou no retorno da questão dos serviços públicos para o centro das controvérsias em matéria de direito administrativo.

Pode-se verificar que, desde o fenômeno da intensificação do papel do Estado na vida social, ocorrido durante a maior parte do século XX, ganharam envergadura também os debates acerca do planejamento da atuação estatal, através da prestação de serviços públicos, tendo-se destacado, mais recentemente, o tema das políticas públicas.

Com efeito, doutrina e jurisprudência têm discutido, com frequiência incomum, assuntos que vão desde o papel reservado ao Estado na economia até a titularidade da prestação de determinados serviços públicos, o seu modo de execução, e mesmo a identificação de tais ou quais atividades como serviço público ou atividade econômica.

Num contexto federalista, como o brasileiro, não se poderia deixar de lado uma intensa discussão a respeito da incumbência para a prestação de cada serviço, questão ligada à repartição das competências materiais. Ao mesmo tempo, contrapondo-se as concepções de federalismo dual e de federalismo de cooperação, coloca-se o adjacente problema da atuação coordenada dos entes públicos das diferentes esferas - federal, estadual e municipal -, e dos instrumentos por meio dos quais se possibilitaria essa coordenação, com a finalidade de gerir, de modo harmônico, as incumbências comuns a esses entes.

Assim, uma das questões relacionadas ao tema, e que tem sido objeto de preocupação dos administradores públicos em geral, é a do desempenho das tarefas constitucionalmente cometidas ao Poder Público conjuntamente por diversos entes da Federação, ou mesmo em cooperação com entidades da administração indireta de cada um deles. Trata-se do reconhecimento de que somente uma conjugação de esforços pode ser apta a proporcionar a adequada gestão de determinados serviços, mormente no que tange aos pequenos Municípios, que constituem, como é cediço, a esmagadora maioria dos entes políticos no Brasil. 
A Constituição Federal de 1988 não descurou do problema, embora trouxesse, originalmente, apenas previsão genérica, constante do parágrafo único do artigo 23, verbis: “Lei Complementar fixará normas para a cooperação entre a União e os Estados, o Distrito Federal e os Municípios, tendo em vista o equilíbrio do desenvolvimento e do bem-estar em âmbito nacional".

Somente mais tarde, pela Emenda Constitucional no 19/98, veio a lume, na nova redação do artigo 241 da Constituição, a expressa previsão dos instrumentos hábeis a pôr em prática a atuação coordenada das políticas públicas: os consórcios públicos e os convênios de cooperação, a serem regulados por lei.

Nesse contexto, trouxe enorme contribuição às discussões o advento da Lei Federal $\mathrm{n}^{\circ}$ 11.107, de 6 de abril de 2005, conhecida como Lei de Consórcios Públicos. O novo diploma regula exatamente as maneiras de os entes públicos cooperarem uns com os outros no interesse da gestão associada de serviços públicos de sua competência.

Pode-se dizer que, por trás dessas inovações legislativas, revela-se o princípio da cooperação interfederativa como vetor que deve informar todo o sistema.

Evidente que esse tipo de cooperação não apareceu somente agora. De há muito se disseminou entre nós a prática dos consórcios intermunicipais, e mesmo dos convênios e outros ajustes envolvendo Estados-membros. O fato é que, enfim, organizou-se juridicamente a possibilidade de contratação de consórcios públicos, regulou-se sistematicamente o modo de fazê-lo e previram-se formalidades e limites para tanto. Mais que isso, agora há a consagração expressa da possibilidade de instituição de uma pessoa jurídica consorcial, bem como da possibilidade de celebração de consórcios com a participação da União.

Com os consórcios, passa a ser regulado também o contrato de programa, instrumento apto a operacionalizar a implementação da gestão associada de serviços públicos no âmbito de um consórcio ou diretamente entre entes federados - podendo envolver ainda entidades da administração indireta -, e que não se confunde com os contratos de consórcio público em si, a ponto de subsistir à extinção destes.

Também o contrato de rateio aparece como instrumento a merecer estudo específico, por sua relação com as obrigações financeiras dos entes consorciados e, como 
decorrência disso, com todas as regras concernentes à responsabilidade fiscal e à probidade administrativa dos partícipes do acordo.

A nova legislação tem suscitado inúmeras questões, inclusive de ordem constitucional, como não poderia deixar de acontecer com algo dessa envergadura, e justifica, por isso, um exame mais detido de suas conseqüências.

O cerne do estudo a ser desenvolvido é a análise dos consórcios públicos em seu atual contexto no direito brasileiro posto, que tem por marco regulatório a Lei de Consórcios Públicos (Lei n. ${ }^{\circ}$ 11.107/2005).

Pretende-se, destarte, compreender, de modo sistematizado, o funcionamento dos consórcios à luz dos princípios federativos constitucionais e de uma exegese crítica da Lei 11.107/05 e de sua regulamentação, em âmbito federal, consubstanciada no Decreto n. ${ }^{\circ}$ $6.017 / 2007$.

Ora, revela-se imprescindível ao administrador público brasileiro e, também, ao estudioso do direito administrativo, a compreensão desses poderosos instrumentos para a execução de políticas públicas. Se a cooperação entre os entes públicos sempre foi perseguida, mesmo na ausência de parâmetros legais, é lícito vaticinar a tendência de que cresça em frequiência e importância sob a égide das recentes inovações normativas.

Como já foi destacado, o compartilhamento de esforços, recursos, bens e pessoal é muitas vezes fundamental para possibilitar determinadas operações estatais que doutra forma não se permitiriam, principalmente no que se refere a Municípios pouco populosos, de escassos recursos orçamentários. Nesse diapasão, problemas como o da falta de investimentos podem ser atacados eficazmente através do consorciamento dos entes interessados, capaz de conjugar os recursos de cada ente federado em prol da gestão ou prestação de determinados serviços necessários a todos eles.

Natural que se faça sentir ao longo do estudo, portanto, a preocupação de se identificar, sob o ponto de vista da regulamentação brasileira, em que medida poderá essa institucionalização do federalismo regional auxiliar a gestão associada dos serviços e políticas públicas e, conseqüentemente, o próprio desenvolvimento do país.

A proposta, portanto, é empreender uma análise objetiva dos consórcios públicos. Não se pretende detalhar aspectos do direito comparado, senão as explanações essenciais 
para demonstrar a influência de outros ordenamentos na adoção do sistema ora vigente no Brasil. Por outro lado, a breve inserção de uma perspectiva histórica dos institutos parece indispensável apenas para situar o debate, motivo pelo qual se procurou não deixar de lado as contingências históricas que justificam as próprias discussões postas em pauta.

Para se alcançar o objetivo da monografia, pretende-se analisar, notadamente, os seguintes assuntos:

a) o funcionamento do modelo federalista brasileiro, no que diz respeito à coordenação entre os entes políticos, destacando-se o atual estágio da cooperação interfederativa;

b) as inovações recentemente introduzidas no modelo de administração pública;

c) os antecedentes históricos que culminaram com o advento dessas figuras jurídicas;

d) as normas do direito brasileiro que emprestam fundamento de validade à constituição de consórcios públicos;

e) a noção de consórcio público, através da identificação de seus elementos essenciais;

f) a natureza jurídica do consórcio e do ato que o institui;

g) o procedimento de formação do consórcio público;

h) as competências dos consórcios públicos, sempre ligadas à gestão associada de serviços públicos;

i) as possibilidades de modificação e extinção do consórcio;

j) o controle, interno e externo, exercido sobre os consórcios públicos;

k) os demais temas inseridos no objeto principal da dissertação, sobretudo o protocolo de intenções, o contrato de rateio, o contrato de programa, a estrutura interna do consórcio, seu pessoal, a responsabilidade dos partícipes etc.;

1) dados a respeito da efetiva utilização do instituto no Brasil; 
m) as discussões mais polêmicas que se têm travado no tocante ao tema, sobretudo quanto a aspectos ligados à constitucionalidade de certas previsões da Lei $\mathrm{n}^{\mathrm{o}} 11.107 / 05$.

Assim é que o presente estudo sobre os consórcios públicos no direito brasileiro se estrutura em 12 capítulos, nos quais se busca analisar desde a importância do federalismo de cooperação para a gênese do instituto até a atual modelagem dos consórcios públicos, disciplinada em recentes normas federais.

Por fim, observamos que, na redação da dissertação, foi utilizado o português brasileiro anterior ao Acordo Ortográfico da Língua Portuguesa, assinado em Lisboa, em 16 de dezembro de 1990, aprovado pelo Decreto Legislativo n. ${ }^{\text { }}$ 54, de 18 de abril de 1995, do Congresso Nacional, e promulgado pelo Decreto n. ${ }^{\circ}$ 6.583, de 29 de setembro de 2008, conforme autorizado pelo parágrafo único do artigo $2^{\circ}$ deste último diploma normativo, que permite a coexistência das normas ortográficas entre $1^{\circ}$ de janeiro de 2009 e 31 de dezembro de 2012.

A dissertação foi elaborada observando-se a Resolução FD/PÓS 01, de 10 de setembro de 2002, bem como a NBR n. ${ }^{\circ}$ 6023-2002 e demais regras aplicáveis da Associação Brasileira de Normas Técnicas. 


\section{FEDERALISMO COOPERATIVO}

\subsection{Raízes do federalismo de cooperação}

A cooperação é inerente ao federalismo. Raul Machado Horta já chamava a atenção para a etimologia da palavra "federal", que vem do latim "foedus", significando, por sua vez, pacto, ajuste, convenção, tratado. Ou seja, já em sua origem o federalismo traz inserida a idéia de cooperação. ${ }^{1}$

Não faz sentido que algum Estado se organize sob a forma federativa, seja por agregação, seja por segregação - como no Brasil -, sem que haja por trás dessa opção uma idéia de união de esforços. Quando vários Estados se reúnem numa federação, expressam nisso uma evidente escolha pela conjugação de seus povos, territórios, governos e ordens jurídicas em prol de um fím comum. De modo similar, quando um Estado unitário se desmembra em uma federação, persiste o espírito de coesão nacional - caso contrário, darse-ia a secessão.

As características do federalismo variam de Estado para Estado; "não existe um modelo abstrato - único, perfeito e acabado - de federação". ${ }^{2}$ Na verdade, o fenômeno federalista deve ser compreendido em sua dimensão dinâmica, em constante mutação no tempo e no espaço, tendo por substrato fixo apenas a organização de comunidades políticas que institucionalizam uma "unidade na diversidade". 3 Ainda assim, para a mínima sistematização do estudo do tema, demanda-se um breve esboço dos traços que podem ser tidos como indicadores do federalismo em qualquer local e época.

Talvez a principal marca identificável em todo Estado federado seja a constante tensão entre a autonomia das unidades e a necessidade de direção convergente da política

${ }^{1}$ HORTA, Raul Machado. O federalismo no direito constitucional contemporâneo. Revista do Tribunal de Contas do Estado de Minas Gerais, Belo Horizonte, v. 19, 2001. Disponível em: <http://www.tce.mg.gov.br/revista $>$. Acesso em: 10 nov. 2008.

2 JUSTEN FILHO, Marçal. Parecer elaborado sobre a proposta legislativa de criação de consórcios públicos. Revista Eletrônica de Direito do Estado, Salvador: Instituto de Direito Público da Bahia, n. 3, jul./set. 2005. Disponível em: 〈http://www.direitodoestado.com.br〉. Acesso em: 14 nov. 2005.

3 BERCOVICI, Gilberto. Desequilíbrios regionais: uma análise jurídico-institucional. 2000. Tese (Doutorado) - Faculdade de Direito da Universidade de São Paulo, São Paulo, 2000. p. 111. 
nacional. O federalismo busca, de certa forma, conciliar a existência de um Estado único embora não unitário - com a autonomia política de entidades subnacionais.

Embora apenas a Federação goze de soberania, todo ente federado desfruta de autonomia, consubstanciada na assunção de competências próprias, inclusive legislativas, cujo exercício não se subordina a outro poder, e que tem por desdobramento também a possibilidade de escolha do próprio governo. ${ }^{4}$

A ascensão política do federalismo clássico, cuja formatação básica foi concebida nos Estados Unidos, apresentava como correspondente jurídico a duplicidade de ordenamentos, pelo que se passou a falar em "federalismo dual". 5 Desde o seu surgimento, e por décadas a fio, o federalismo dual foi responsável por descrever, explicar e determinar as relações entre nação e Estados, baseadas na autonomia. ${ }^{6}$

Em suma, havia a idéia de que os entes da Federação eram igualmente soberanos, dotados de competências taxativas, não podendo um deles intervir nos assuntos pertinentes aos demais. Tratava-se da afirmação da autonomia como elemento fundamental do Estado federado.

Embora a prática dos Estados federados já começasse a admitir, desde o início do século XX, atenuações ao federalismo puramente dual, foi sobretudo a partir dos estudos do norte-americano Daniel J. Elazar que o enfoque teórico passou a opor às antigas concepções uma idéia de federalismo baseado na cooperação interna. ${ }^{7}$

É certo que, nos períodos mais remotos do federalismo, quando o modelo dual atingiu um nível radical de concreção, a cooperação entre os entes da Federação foi praticamente deixada de lado. Mas se a concepção dualista ainda hoje tem seu papel no federalismo, a história tem mostrado, por outro lado, que o respeito à autonomia dos entes

${ }^{4}$ DALLARI, Dalmo de Abreu. Parecer sobre a proposta legislativa de criação de consórcios público. Disponível em: <http://www.planalto.gov.br/ CCIVIL_03/revista/Rev 72/pareceres/consorcio_DalmoAbreuDallari.pdf>. Acesso em: 14 nov. 2005.

5 ZIMMERMAN, Joseph F. National State relations: cooperative federalism in the twentieth century. Publius: the Journal of Federalism, Easton, v. 31, n. 2, p. 17, 2001.

${ }^{6}$ Para uma abordagem detalhada da história do federalismo nos Estados Unidos, cf. RODRIGUES, Nina Trícia Disconzi. Novos rumos para o federalismo: contribuições para a sua melhoria. 2007. Tese (Doutorado) - Faculdade de Direito da Universidade de São Paulo, São Paulo, 2007. p. 21-69.

${ }^{7}$ ZIMMERMAN, op. cit., p. 18-19. Cf. também KEYNON, Daphne A.; KINCAID, John. Daniel J. Elazar cooperative federalism. Washington, DC: The Urban Institute Press, 1992. p. 73. 
federados deve se compatibilizar, em maior ou menor grau, com a cooperação entre as unidades-membro. Com efeito, nota-se que a evolução do Estado federal se dá no sentido de promover a associação para um fim comum, consubstanciado, em última análise, no bem-estar da sociedade. ${ }^{8}$

Mas a cooperação, mais do que natural no modelo federalista, é inerente aos interesses humanos. Nas palavras de Pedro Durão, "em todas as etapas construtivas e reformistas da vida dos povos, o movimento coletivo de solidariedade assume o papel congregador e consolidador", 9 sendo certo que "a cooperação, dentro de um aspecto geral e como fenômeno social, advém do conflito, ou surge como uma forma de neutralizar seus efeitos". ${ }^{10}$

Assim, a atuação concertada muitas vezes carrega ínsito um princípio de solidariedade com vistas ao equacionamento de conflitos, mas não só: também a persecução de interesses individuais justifica a colaboração entre entes dotados de autonomia de vontade. É comum que diferentes pessoas ou coletividades se auxiliem mutuamente não por motivos puramente altruístas, nem tampouco por mero senso de colaboração, mas pela própria necessidade de obter certas benesses que seriam inalcançáveis de outro modo.

A atuação concertada, portanto, pode ser motivada por fins de interesse comum ou pela busca de interesses individuais. A primeira hipótese, quando aplicada à atuação dos órgãos e entidades públicas, pode ser denominada, de modo amplo, por "coordenação gerencial”, no esteio da lição de Diogo de Figueiredo Moreira Neto. ${ }^{11}$ É desse tipo de cooperação que se originam os convênios e os contratos plurilaterais ou de comunhão de escopo, como os de sociedade. A segunda hipótese dá origem aos demais tipos de acordos, como os contratos bilaterais ou sinalagmáticos. Ao longo deste estudo, sempre que nos referirmos à cooperação na Administração Pública, focalizaremos em primeiro plano o aspecto da coordenação.

\footnotetext{
${ }^{8}$ CARVALHO FILHO, José dos Santos. Consórcios públicos. Rio de Janeiro: Lumen Juris, 2009. p. 5.

${ }^{9}$ DURÃO, Pedro. Convênios e consórcios administrativos: gestão, teoria e prática. Curitiba: Juruá, 2004. p. 29.

${ }^{10}$ Ibid., p. 139.
} 
Sem prejuízo de tais considerações, que têm prestigiado uma acepção ampla do termo "cooperação", caberia registrar outro sentido do termo, mais estrito, que não se confunde com a coordenação propriamente dita. Sob essa ótica, a coordenação seria "um modo de atribuição e exercício conjunto de competências no qual vários integrantes da Federação possuem certo grau de participação", havendo equivalência e liberdade da vontade das partes, que mantêm integralmente suas competências, podendo atuar de maneira isolada ou autônoma. ${ }^{12}$ Já na cooperação, não se viabiliza a atuação em separado dos entes federados, sendo mister que todos eles exerçam suas competências em conjunto. Exemplo da cooperação em sentido estrito seria o art. 23 da Constituição Federal, instituidor das chamadas competências comuns. ${ }^{13}$

Outra característica da cooperação que merece destaque é o fato de esta pressupor vontades próprias, autônomas, emanadas das pessoas que cooperam. ${ }^{14}$ Por isso é que, no âmbito do Estado Federado, a cooperação ganha um significado especial, na medida em que se consubstancia em ajustes firmados entre pessoas dotadas de autonomia política. Ainda que seja admissível falar em "cooperação" entre diversos órgãos administrativos pertencentes a uma mesma pessoa jurídica, não se pode negar a dificuldade de se entrever, nesses casos, um ajuste de vontades, um verdadeiro "consenso". Ora, se os órgãos são desprovidos de personalidade jurídica, não possuem vontade própria, pelo menos não no sentido técnico da expressão. Ao contrário, submetem-se à vontade da pessoa jurídica na qual se inserem, e as relações entre eles obedecem ao princípio da hierarquia administrativa. ${ }^{15}$ Portanto, é nas relações entre diferentes entes políticos, dotados de personalidade jurídica própria - no caso brasileiro, União, Estados, Distrito Federal e

11 MOREIRA NETO, Diogo de Figueiredo. Coordenação gerencial na administração pública. Revista de Direito Administrativo, Rio de Janeiro, n. 214, p. 35-53, out./dez. 1998.

12 BERCOVICI, 2000, p. 123. O autor invoca a propósito o escólio de Enoch Alberti Rovira, em "Federalismo y cooperación en la República Federal Alemana", p 369-370, e de Raul Machado Horta, em “Repartição de competências na Constituição Federal de 1988”, p. 364-366.

${ }^{13}$ Ibid., p. 125.

${ }^{14}$ MOURA, Valdiki. Democracia econômica: introdução à economia cooperativa. São Paulo: Cia. Editora Nacional, 1942. p. 4, apud DURÃO, 2004, p. 28.

15 Nesse mesmo sentido, a doutrina tem repudiado a menção a "contratos" entre órgãos, que não gozam de personalidade jurídica. Cf. DI PIETRO, Maria Sylvia Zanella. Parcerias na administração pública. $6^{\mathrm{a}}$ ed. São Paulo: Atlas, 2008, p. 260/261; SANTIAGO, José Maria Rodríguez de. Los convenios entre administraciones públicas. Madrid: Marcial Pons, 1997, p. 340. 
Municípios -, que se verifica o terreno propício para a cooperação, em sua acepção mais significativa.

Conforme ensina Gilberto Bercovici, a cooperação num Estado federado se dá em "dois momentos de decisão": a determinação, em nível federal - mas com participação das entidades subnacionais -, das medidas a serem adotadas, "uniformizando-se a atuação de todos os poderes estatais competentes em determinada matéria”; e a adaptação, em nível estadual ou municipal, da decisão tomada às características e necessidades de cada ente federado. ${ }^{16}$

No âmbito do Estado federado, a cooperação apresenta-se sob diversos formatos, que vão do planejamento integrado de políticas públicas até o auxílio financeiro, passando pelo compartilhamento de recursos e pela gestão associada de serviços públicos, podendo as ações ser coordenadas a partir de um sistema representativo das unidades subnacionais ou pela participação direta destas. ${ }^{17}$

É a impossibilidade de os Estados-membros agirem isoladamente, adotando perspectivas originárias para orientar sua atuação em meio a um contexto estatal voltado à implementação de políticas públicas, que pavimenta o caminho para a implantação de um federalismo capaz de emprestar tratamento uniforme ou coerente aos problemas nacionais: o federalismo cooperativo. Daí a concepção desse modelo de federalismo como o "adequado ao Estado Social". ${ }^{18}$

Por outro lado, deve-se desvincular da idéia de atuação coordenada das esferas a conotação de centralização, e substituí-la pela de homogeneização, a qual, segundo Gilberto Bercovici, é

baseada na cooperação, pois se trata do processo de redução das desigualdades regionais em favor de uma progressiva igualação das condições sociais de vida em todo o território nacional. A

${ }^{16}$ BERCOVICI, Gilberto. Dilemas do estado federal brasileiro. Porto Alegre: Livraria do Advogado, 2004. p. 60-61.

17 DIAS, Solange Gonçalves. Possibilidades jurídico-institucionais dos consórcios públicos. 2006. Tese (Doutorado) - Faculdade de Direito da Universidade de São Paulo, São Paulo, 2006, p. 74.

${ }^{18}$ BERCOVICI, 2004, p. 56-57. 
homogeneização não é imposta pela União, mas é vontade de todos os membros da Federação,

ao passo que, na centralização, "há a concentração de poderes na esfera federal, debilitando os entes federados em favor do poder central". ${ }^{19}$

De todo modo, fato é que parece existir uma relação de proporção direta entre a opção política de um Estado provedor, intervencionista, e a atribuição de mais competências e responsabilidades à União. Mesmo sem adentrar a experiência concreta dos Estados federados nesse sentido, é possível supor, ao menos em teoria, que a autonomia plena dos Estados, numa conjuntura de desnível econômico preexistente, favorece um desenvolvimento descompassado, potencial causador de desigualdades regionais. De outro lado, um Estado que pretenda reduzir desigualdades é um Estado necessariamente orientado por uma lógica redistributiva, estruturado para possibilitar uma flexível realocação de recursos conforme as prioridades eleitas em escala nacional.

Sob essa ótica, é inevitável constatar que, num contexto federativo, a União assume o papel central na busca pela redução das desigualdades regionais, comandando o planejamento e realizando investimentos essenciais à atenuação das disparidades sociais, permitindo assim a prestação de serviços públicos adequados e equivalentes em âmbito nacional. Em decorrência disso, coloca-se justamente como o grande desafio da cooperação interfederativa a busca por "resultados unitários e uniformizadores sem esvaziar os poderes e competências dos entes federados em relação à União", mas, ao contrário, "ressaltando a sua complementaridade". ${ }^{20}$

Pedro Durão enumera alguns princípios que entende aplicáveis especificamente à cooperação administrativa (entendida esta de modo amplo, como a cooperação no âmbito do Estado). Seriam eles o da cooperação acordada; do ingresso livre e voluntário; do interesse público primário; da vinculação ao ato convenial ou consorcial; e o da responsabilidade de seus partícipes e executores. ${ }^{21}$

\footnotetext{
${ }^{19}$ Ibid., p. 57.

${ }^{20}$ BERCOVICI, 2004, p. 57-59.

${ }^{21}$ DURÃO, 2004, p. 30-33.
} 
Quanto ao primeiro princípio, note-se que, mais que um postulado aplicável à cooperação administrativa, parece ser a própria definição de cooperação, eis que descrito pelo autor como "a colaboração comum entre entes para fins de serviços públicos assegurados pelo Estado". ${ }^{22}$ O segundo princípio pressupõe a autonomia de vontade dos partícipes, implicando a participação espontânea destes no ajuste. Apresenta, como corolário, a impossibilidade de aplicação de penalidade em caso de saída de um dos cooperados. O terceiro princípio, do interesse público primário, erige-se, na verdade, em mandamento fundamental do direito público, na medida em que a ação administrativa sempre deve, em última análise, persegui-lo. Pelo quarto postulado pressupõe-se, de um lado, a forma escrita do instrumento de regência, e, de outro, a clareza e o detalhamento de suas cláusulas, que devem ser devidamente cumpridas, em atenção à manifestação de vontade autônoma. Talvez seja possível enxergar aí a máxima romana do pacta sunt servanda, e, considerando-se que o instrumento consorcial necessita de aprovação legislativa, também uma decorrência lógica do princípio da legalidade. Em relação ao último princípio enumerado, cumpre anotar que, como é cediço, o Estado se responsabiliza por eventuais danos decorrentes da sua atuação, independentemente da forma como esta se dê. Além disso, seria até desnecessário acrescentar que os agentes públicos, bem como os particulares que prestam serviços públicos, podem ser também responsabilizados, inclusive por ato de improbidade administrativa. De qualquer forma, trata-se de princípio aplicável à atuação estatal como um todo, a teor do art. $37, \S 6 .^{\circ}$, da Constituição Federal, não se restringindo à disciplina da cooperação administrativa.

A rigor, o fundamental é ter em conta que toda forma de cooperação intra-estatal se estrutura sob os princípios do direito público, especialmente nos ramos do direito constitucional, do direito administrativo e do direito financeiro.

No mundo cada vez mais globalizado em que vivemos hoje, salta aos olhos a gradativa aproximação não só entre as diversas comunidades locais de um mesmo país, mas também, e ainda mais visivelmente, entre as diferentes nações, fenômeno que se faz sentir sobretudo nos blocos continentais como a Europa, cuja união já situa a comunidade entre uma ordem constitucional cooperativa e um verdadeiro pacto federativo. No Velho Continente, os trabalhos para elaboração de um projeto de Constituição cogitaram a adoção

${ }^{22}$ Ibid., p. 30. 
do princípio federal - posteriormente abandonado -, e consagraram o movimento dialético entre as lógicas internacional e interna. ${ }^{23}$

Se no mundo todo a cooperação tem estado em pauta, com ainda mais razão podese dizer que, em todos os Estados federados, encontram-se atualmente nítidos sinais do modelo cooperativo. ${ }^{24}$

Nos Estados Unidos, malgrado se encontrem atualmente críticas à capacidade da teoria do federalismo cooperativo para explicar as relações freqüentemente "coercivas" entre os entes federados, ${ }^{25}$ doutrina e jurisprudência parecem ter se pacificado em torno dos postulados básicos que explicam a natureza das relações cooperativas entre Nação e Estados:

1 - Each plane of government possesses certain autonomous powers that may be exercised cooperatively, with such cooperation initiated by either plane.

2 - One plane of government does not coerce the other plane of government.

3 - The roles of Congress in terms of national-state relations facilitating and leadership ones.

4 - Congress uses its power to regulate interstate commerce to assist states by prohibiting use such commerce in violation of state laws.

5 - Cooperation is negotiated. ${ }^{26}$

23 BLANQUER, Jean-Michel. Le projet de Constitution européenne: entre pacte fédératif et ordre constitutionnel coopératif. Revue du Droit Public et de la Science Politique en France et à l'Étranger, Paris, n. 5, p. 1275-1279, sept./oct., 2003.

24 Mais especificamente quanto aos institutos estrangeiros similares aos consórcios interfederativos brasileiros, cf. o item 6.3 infra.

${ }^{25}$ ZIMMERMAN, 2001, p. 27.

${ }^{26}$ ZIMMERMAN, 2001, p. 19-20. Em tradução livre:

1 - Cada esfera de governo possui certos poderes autônomos que podem ser exercitados cooperativamente, sendo tal cooperação iniciada por qualquer das esferas.

2 - Uma esfera de governo não coage a outra.

3 - Papel do Congresso na liderança e facilitação das relações entre Nação e Estados. 
Na Alemanha, o art. 35, 1, da Constituição prevê expressamente a colaboração administrativa entre os diversos entes públicos:

1. Todas as autoridades federais e estaduais prestar-se-ão mutuamente assistência judicial e administrativa.

Nos itens 2 e 3 do mesmo artigo, a atuação cooperativa é viabilizada de forma específica para a área da segurança e ordem públicas:

2. Com vista a manter ou restabelecer a segurança ou a ordem pública, um Estado poderá, em casos particularmente graves, recorrer às forças e equipamentos da Polícia Federal de Fronteiras para atender às necessidades da sua polícia, caso esse apoio seja absolutamente imprescindível para o cumprimento de determinada missão, ou quando a falta desse apoio implicar sérias dificuldades. Para enfrentar catástrofe natural ou sinistro particularmente grave, um Estado poderá recorrer à ajuda de forças policiais de outros Estados, forças e equipamentos de outras autoridades administrativas, da Polícia Federal de Fronteiras e das Forças Armadas.

3. Se catástrofe natural ou sinistro ameaçar o território de mais de um Estado, o Governo Federal poderá, desde que indispensável para um combate eficaz, instruir os governos estaduais a emprestarem forças policiais a outros Estados, bem como mobilizar unidades da Polícia Federal de Fronteiras e das Forças Armadas para apoiar as forças policiais. Medidas tomadas pelo Governo Federal nas circunstâncias previstas na primeira frase deste parágrafo poderão ser canceladas, a qualquer tempo, a pedido do Conselho Federal, e, obrigatoriamente, tão logo afastado o perigo.

4 - O Congresso usa seu poder para regular o comércio interestadual de auxílio aos Estados proibindo o uso de tal comércio em violação às leis estaduais. 
Também na Austrália o princípio constitucional implícito do federalismo cooperativo determina que as diferentes esferas de governo trabalhem conjuntamente para obter resultados que de outra forma não poderiam ser atingidos, lançando-se mão, para tanto, de meios que sejam compatíveis e não contrariem a Constituição. ${ }^{27}$

Tais meios, conquanto variados, tendem a ser interpretados restritivamente, naquele país. Com efeito, ao tratar da possibilidade de cooperação legislativa entre os diferentes parlamentos à luz de uma decisão da Suprema Corte australiana no caso The Queen vs. Hughes, o autor Alex de Costa conclui que o princípio implícito do federalismo cooperativo não vai ao ponto de permitir todo meio de cooperação que não esteja expressamente vedado pela Constituição, sendo limitado de acordo com a competência de cada Legislativo. ${ }^{28}$ Assim, o princípio implícito do federalismo cooperativo, ao menos em matéria legislativa, teria perdido muito de seu conteúdo em face das conclusões da High Court australiana no referido caso, em que se restringiu a interpretação acerca das possibilidades de cooperação legislativa em desfavor da Commonwealth (União), que, no caso, buscava fiscalizar a aplicação da Corporations Law. $^{29}$

Mais próximo da estrutura do federalismo brasileiro - reconhecendo, por exemplo, o Município como entidade autônoma -, o federalismo argentino distancia-se do nosso em sua origem, mais intensamente ligada a um substrato histórico e cultural residente na preexistência de províncias que, após reunidas, conservaram todo o poder que não delegaram expressamente à Nação. ${ }^{30}$

A Constituição argentina faculta às províncias a criação de regiões, que em hipótese alguma podem constituir um novo governo. Naquele país, fala-se na regionalização em três níveis: supraordenação (regionalismo verticalista, emergente do poder central); coordenação (regionalismo concertado, entre os poderes provinciais e central); e

5 - A cooperação é negociada.

${ }^{27}$ COSTA, Alex de. The corporations law and cooperative federalism after the Queen v Hughes. The Sydney Law Review, Sydney, v. 22, n. 3, p. 465, Sept. 2000.

${ }^{28}$ Ibid., loc. cit.

${ }^{29}$ Ibid., p. 466.

${ }^{30}$ DROMI, José Roberto. Derecho administrativo. 5. ed. Buenos Aires: Ediciones Ciudad Argentina, 1996. p. 137. 
subordinação (regionalismo horizontal, por iniciativa e faculdade dos Estados-membros), sendo o regionalismo concertado, para Roberto Dromi, "el que más eficientemente compatibiliza los intereses de la unidad nacional com la diversidad local". ${ }^{31}$ Nesse sentido, o "tratado regional" viabiliza a homogeneização do país, favorecendo a solidariedade entre as províncias através dos arranjos cooperativos, e possibilitando o fomento do desenvolvimento econômico e social. ${ }^{32}$ Para o cumprimento de tais acordos regionais, abre-se às províncias a faculdade de criarem os órgãos administrativos hábeis a levar a cabo a efetiva implementação dessa alternativa de gestão "para un federalismo eficiente". ${ }^{33}$

A Argentina conta ainda com outros instrumentos do federalismo cooperativo, a exemplo da lei-convênio, a qual, no campo da divisão das receitas tributárias, é definida como "um verdadero contrato entre las provincias y la Nación sobre el reparto impositivo", e a celebração de tratados interprovinciais, responsáveis pela criação de direito interno. ${ }^{34}$

Logo se vê que o grau de complexidade do federalismo cooperativo na Argentina revela-se consideravelmente avançado, mormente quando se tem em conta que, aos supracitados institutos, soma-se a possibilidade de se instituírem "empresas interprovinciais" ou "entes regionais", estruturados em administrações especiais supraprovinciais ou interprovinciais encarregadas de promover uma ou mais atividades específicas e comuns a duas ou mais províncias, e de empresas ou associações intermunicipais, com o objetivo de prestação de serviços de interesse comum dos municípios integrantes nas mais variadas áreas. ${ }^{35}$

Em suma, parece claro que os Estados federados, de modo geral, têm atentado para as vantagens da união interna rumo ao desenvolvimento nacional, atraídos certamente, como se verá mais adiante, por indicadores como a economia de gastos e o intercâmbio de experiências administrativas, além de, acima de tudo, “a possibilidade de implementar

\footnotetext{
${ }^{31}$ DROMI, 1996, p. 138, 183. Em tradução livre, “o que mais eficientemente compatibiliza os interesses da unidade nacional com a diversidade local".

${ }^{32}$ Ibid., p. 183.

${ }^{33}$ Ibid., loc. cit..

${ }^{34}$ Ibid, p. 182-184.

${ }^{35}$ Ibid., p. 464-465.
} 
políticas públicas, que, como processo de formação do interesse público, devem ser vistas como escolha de prioridades regionais". ${ }^{36}$

\subsection{Federalismo brasileiro}

No Brasil, o federalismo, como não podia deixar de ser, ostenta configuração singular, inconfundível com qualquer outra formatação de Estado federado. O Estado brasileiro, instalando-se sobre três níveis federativos igualmente autônomos (União, Estados/Distrito Federal e Municípios), consagrou uma complexa divisão de competências federativas, cujo exame, ainda que perfunctório, faz-se imprescindível para a plena compreensão do tema a ser tratado ao longo desta monografia, uma vez que o consórcio público não é senão uma entidade interfederativa dotada de competências transferidas de seus partícipes.

Inicialmente, deve-se advertir para a diferença entre as competências de índole legislativa e as de natureza material. Aquelas, que autorizam a edição de leis sobre determinados assuntos, dividem-se em exclusivas (ou privativas) de cada ente e concorrentes, afetas a todos eles. As competências materiais, que representam a atribuição, conferida constitucionalmente, para a realização de determinada atividade políticoadministrativa - prestação de um serviço público, edição de um ato de efeitos concretos, promoção de determinado fim considerado relevante - são comumente separadas em privativas (ou exclusivas), que só podem ser exercidas pelo ente a quem foram cometidas, e comuns, exercitáveis simultaneamente por todos os componentes da Federação.

Importa aqui traçar breve consideração terminológica: não obstante as competências de titularidade de somente um dos entes federados sejam tratadas pela maior parte da doutrina, indistintamente, por competências privativas ou exclusivas, cabe registrar a posição dos autores que, apoiados em José Afonso da Silva, ${ }^{37}$ consideram como

${ }^{36}$ CAMPOS, Lílian Maria Salvador Guimarães. Consórcios públicos na administração pública brasileira: em busca de uma administração pública consensual. 2006. Dissertação (Mestrado) - Universidade Federal do Paraná, Curitiba, 2006. p. 114.

${ }^{37}$ SILVA, José Afonso da. Curso de direito constitucional positivo. 25. ed. São Paulo: Malheiros Editores, 2005. p. 457. 
privativas apenas aquelas competências que podem ser delegadas, sendo exclusivas as demais. A separação entre competências delegáveis e indelegáveis repercute, notadamente, no estudo da atribuição de competências ao consórcio público. ${ }^{38}$

Sob outro ponto de vista, vislumbram-se duas técnicas de repartição das competências: a horizontal, na qual as competências (legislativas ou materiais) são delimitadas por assunto em cada esfera federativa, de modo que um ente não possa exercer a competência atribuída ao outro; e a vertical, segundo a qual a competência (legislativa ou material) sobre um determinado assunto é conferida a União, Estados e Distrito Federal. Em se tratando de competência legislativa, essa distribuição se dá em diferentes graus, ou seja, à União cabe editar normas gerais, e aos Estados e Distrito Federal cabe suplementar a legislação federal.

As competências exclusivas ou privativas da União e dos Municípios encontram-se enumeradas no texto constitucional. $\mathrm{O}$ art. 21 estabelece as competências materiais da União, e o art. 22, as legislativas. No art. 30 encontra-se o rol das competências materiais e legislativas dos Municípios, cabendo aos Estados exercer a competência dita remanescente $\left(\operatorname{art.} 25, \S 1^{\mathrm{o}}\right)$.

Em regra, temos portanto que a Constituição estabelece as competências de cada um dos entes federados, que as exercerão separada e independentemente, ficando tais competências, em princípio, vedadas aos demais, salvo previsão expressa de atuação concorrente. $^{39}$

Quanto aos municípios, importa assinalar a imprecisão do conceito de "interesse local", erigido pelo constituinte como determinante da competência privativa municipal. A vagueza do termo gera dificuldades diante de situações ambíguas, mas, por outro lado, "garante uma elasticidade que dá margem a uma evolução da compreensão do texto constitucional, diante da mutação por que passam algumas atividades e serviços, em

${ }^{38}$ Cf. item 8.2.2 infra.

${ }^{39}$ ALMEIDA, Fernanda Dias Menezes de. Competências na Constituição de 1988. 3. ed. São Paulo: Atlas, 2005. p. 84-85; e BERCOVICI, 2004, p. 61. 
especial quando se consideram as alterações tecnológicas, sócio-econômicas e institucionais". 40

As competências materiais comuns, constantes do art. 23 da Lei Maior, também chamadas cumulativas ou paralelas, são aquelas que cabem, simultaneamente, a todos os entes federativos. Para muitos autores, tais atribuições trazem consigo também a necessidade de que, para serem efetivadas, sejam editadas leis sobre o assunto, donde se falar em competência legislativa imprópria ou secundária, já que não está expressamente prevista como tal. $^{41}$

As competências concorrentes (art. 24), por sua vez, consistem em modo de partilha vertical inspirado no art. 10 da Constituição alemã de 1919, a Constituição de Weimar, cuja idéia é que a União tome as decisões políticas de abrangência geral, deixando aos entes menores (Estados) a possibilidade de adequar as normas em que se consubstanciam tais decisões a suas peculiaridades, traçando pormenores sobre o mesmo assunto, ou mesmo editando as normas gerais, caso a União não o faça.

Assim é que, não obstante a pouca precisão dos textos constitucionais que se sucederam em nossa história republicana, os quais ora falavam em competência complementar, ora em competência supletiva, parece ter a doutrina finalmente firmado o entendimento, sob a égide da Constituição de 1988, de que o que lá está tratado como competência suplementar dos Estados-membros envolve dois tipos de poder: o de adaptar as normas gerais às necessidades dos Estados, que poderão portanto editar leis especiais a respeito do assunto (competência complementar); ${ }^{42}$ e o de editar, além das normas especiais, também as gerais, apenas na hipótese de inércia do governo federal em fazê-lo (competência supletiva).

${ }^{40}$ GROTTI, Dinorá Adelaide Musetti. O serviço público e a Constituição Brasileira de 1988. São Paulo: Malheiros Editores, 2003. p. 94.

41 Nesse sentido, ARAÚJO, Luiz Alberto David; NUNES JÚNIOR, Vidal Serrano. Curso de direito constitucional. 4. ed. São Paulo: Saraiva, 2001. p. 211-212; e ALMEIDA, 2005, p. 150.

42 É de se questionar, contudo, a prevalência de norma estadual, editada com base na competência complementar, sobre norma federal de caráter geral que lhe seja contrária. O que parece advir do texto constitucional é a possibilidade de se adicionarem pormenores à lei federal, e não de inovar contra ela. 
Diante da previsão do art. 30, II da Constituição Federal, que fala em competência suplementar dos Municípios, tem-se questionado se estes também se enquadrariam no sistema de repartição vertical de competências.

A doutrina oferece diferentes soluções a essa indagação, tendo todas elas em comum a exigência de que a edição de leis municipais, mesmo quando admitida em sede de competência concorrente, deve sempre ter em vista o "interesse local". Para autores como Luiz Albert David Araujo e Vidal Serrano Nunes Júnior, os Municípios exercem a competência suplementar nos mesmos moldes da concedida aos Estados, como se tivessem figurado no caput do art. 24. ${ }^{43}$ Assim, poderiam os Municípios detalhar as leis federais e estaduais para atender a interesses locais, e inclusive suprir suas lacunas.

José Afonso da Silva concorda com a existência de competência suplementar, podendo os Municípios legislar sobre as matérias arroladas no art. 24 da Constituição - e não somente sobre as matérias expressamente afetas a sua competência - desde que se evidencie o interesse específico da comuna, como por exemplo "educação, cultura, ensino e saúde no que tange à prestação desses serviços no âmbito local". ${ }^{4}$

Para Ubirajara Custódio Filho, fica afastada a possibilidade de o Município se valer de competências reservadas à União ou aos Estados, e se impõe, ao lado da necessidade de efetiva constatação do interesse local, a compatibilização das normas editadas com base nessa competência quanto à legislação federal e estadual. ${ }^{45}$ André Ramos Tavares segue a mesma linha de raciocínio, destacando a expressão "no que couber", utilizada no inciso II do art. 30, para concluir que a competência municipal a que alude o dispositivo deve atender à existência de interesse local e se coadunar com a legislação da União e do Estado - em cujo território se encontra - sobre a matéria. ${ }^{46}$

Manoel Gonçalves Ferreira Filho, ${ }^{47}$ adotando entendimento bastante semelhante, observa que, se o legislador constituinte silenciou a respeito dos Municípios ao tratar da

43 ARAÚJO; NUNES JÚNIOR, 2001, p. 204.

44 SILVA, 2005, p. 643.

${ }^{45}$ CUSTÓDIO FILHO, Ubirajara. As competências do Município na Constituição Federal de 1988. São Paulo: Celso Bastos Editor, 2000. p. 86.

46 TAVARES, André Ramos. Curso de direito constitucional. 2. ed.. São Paulo: Saraiva, 2003. p. 841.

${ }^{47}$ FERREIRA FILHO, Manoel Gonçalves. Comentários à Constituição brasileira de 1988. São Paulo: Saraiva, 1990. v. 1, p. 219. 
competência concorrente, é porque não quis conceder-lhes a possibilidade de suplementar a legislação federal ou estadual. A competência a que se refere o art. 30, II, teria, assim, natureza verdadeiramente administrativa, de regulamentação das leis mais abrangentes, desde que haja interesse local a justificá-la, isto é, desde que seja preciso "ajustar sua execução a peculiaridades locais".

No mesmo sentido parece caminhar a lição de Alexandre de Moraes, para quem os Municípios, embora possam suprir omissões e lacunas da legislação federal e estadual, não podem contrariar essa legislação, limitando-se a regulamentá-la, sempre atentos à presença de interesse local. ${ }^{48}$

Com efeito, é de se notar que a Constituição Federal de 1988 não inclui o Município dentre os titulares de competência concorrente, e isso não pode passar despercebido. Os dispositivos constitucionais devem ser interpretados da maneira que melhor favoreça a sua harmonização, descartando-se, de plano, a possibilidade de que um deles seja aplicado em detrimento de outro.

Se o art. 24 parece apontar para a total exclusão das atribuições legislativas dos Municípios no tocante às matérias ali enumeradas, por outro lado o art. 30, II, dá a entender que eles gozam da mesma competência que os Estados - a palavra utilizada é idêntica: suplementar. Mas não há antinomia. Ambos os dispositivos devem ser aplicados. E isso mediante a interpretação que permita sua coexistência: a de que a competência suplementar dos Municípios de fato existe, mas com alcance reduzido em comparação à concedida aos Estados, pois só é possível "no que couber", ou seja, quando houver interesse local e, ao mesmo tempo, significar mera regulamentação, detalhamento, das normas já existentes sobre a matéria, nos âmbitos federal e estadual.

Isso, evidentemente, não afasta as competências exclusivas do Município, e nem tampouco, para alguns autores, sua competência concorrente imprópria, ou seja, a possibilidade de editar leis sobre as matérias referidas no art. 23 da Constituição, que, apesar de se revestirem de natureza material, podem necessitar, para sua implementação, de base legislativa.

${ }^{48}$ MORAES, Alexandre de. Direito constitucional. 12. ed. São Paulo: Atlas, 2002. p. 303. 
Traçadas as linhas mestras da distribuição de competências legislativas, pode-se concluir que a ordem jurídica total, estabelecida na Constituição Federal, decompõe-se em uma ordem jurídica parcial central, emanada da União, e ordens jurídicas parciais locais, dos Estados-membros e Municípios. ${ }^{49}$

Fica claro também, da análise da repartição constitucional de competências, que, entre nós, é a União que detém a maior parte das atribuições legislativas e materiais, o que tem levado alguns autores a registrar a impressão generalizada de que o federalismo brasileiro encontrar-se-ia, no atual estágio de evolução, severamente prejudicado pela concentração de poderes da União, tornando Estados e Municípios meros "súditos" do poder central. $^{50}$

Não bastasse a concentração de competências da União, parte da doutrina denuncia ainda a ausência de cooperação e solidariedade entre os entes da Federação, capazes de entrar em conflito por verbas federais, ou mesmo de se envolver em intermináveis guerras fiscais, caracterizadas pelo oferecimento de incentivos tributários para a instalação de sedes e fábricas de empresas em seus territórios, ${ }^{51}$ instaurando um verdadeiro federalismo "predatório". 52

Embora seja evidente a desproporção de competências nas mãos da União, assim como a existência de tensões federativas em busca de recursos, as críticas engendradas ao modelo federativo atualmente vigente soam algo exacerbadas quando se tem em vista que a nova ordem constitucional operou uma descentralização significativa em relação ao que se construíra sob o anterior ordenamento ditatorial. Além disso, como se verá a seguir, ${ }^{53} \mathrm{o}$ federalismo brasileiro é resultante de um processo histórico desenvolvimentista que naturalmente reforçou as competências federais, mesmo em períodos democráticos.

\footnotetext{
${ }^{49}$ CAMPOS, 2006, p. 71.

${ }^{50}$ Ibid., p. 77.

${ }^{51}$ LOVATO, Luiz Gustavo. Federalismo e federalismo fiscal: controvérsias sobre o sistema brasileiro de desenvolvimento regional. Jus Navigandi, Teresina, 31 mar. 2006. Disponível em: <http://jus2.uol.com.br/doutrina/textoasp?id=8179>. Acesso em: 15 out. 2007.

52 CARVALHO, André Regis. Reengenharia federativa: a questão dos consórcios intermunicipais, in FIGUEIREDO, Carlos Maurício; NÓBREGA, Marcos. Administração pública: direito administrativo, financeiro e gestão pública - prática, inovações e polêmicas, São Paulo: RT, 2002, p. 82.

${ }^{53}$ Cf. item 2.3 infra.
} 
Com efeito, além da devolução de parte do poder dos Estados, a descentralização empreendida a partir de 1988 inseriu definitivamente o Município no quadro federativo brasileiro, aumentando sua importância e sua capacidade de intervenção nos problemas locais. 54

Mas ao mesmo tempo em que essa emancipação municipal se revelava como a maior inovação do federalismo brasileiro contemporâneo, talvez tenha sido justamente esse o principal problema gerado pelo novo sistema constitucional: a ampliação das competências municipais na Constituição de 1988 não se fez acompanhar da necessária distribuição de receitas para fazer frente às novas responsabilidades. ${ }^{55}$

Sob esse quadro, foram criados inúmeros novos Municípios, atraídos pelo novo estatuto constitucional a eles dedicado. Tal ordenamento tem garantido, além da sobredita maior autonomia, consideráveis aportes financeiros oriundos dos fundos de participação cuja função é eminentemente redistributiva, compensando-se as localidades menos favorecidas pela arrecadação com repasses financeiros mais vultosos. ${ }^{56}$ Grande parte dos Municípios nascidos debaixo dessas condições, entretanto, viram-se desprovidos da mínima viabilidade econômico-fiscal. ${ }^{57}$

Ante tais constatações, Nina Trícia Disconzi Rodrigues chega a sugerir, como alternativa para viabilizar o federalismo cooperativo, o abandono da padronização jurídica dos municípios (haja vista a substancial diferença real existente entre as localidades), e, com isso, a quebra da simetria federalista brasileira quanto ao municipalismo, com a superação do critério de interesse local sobre o qual se erige a autonomia municipal. Como consequiência, resultaria mais fácil o planejamento de políticas públicas descentralizadas que concretizariam o federalismo cooperativo. Mais que isso, defende a proposta de criação, via emenda constitucional, de "uma regra de revisão periódica da emancipação dos

\footnotetext{
${ }^{54}$ CARVALHO, André Regis. Ob. cit., p. 89.

${ }^{55}$ CAMPOS, Lílian Maria Salvador Guimarães. Ob. cit., p. 85.

${ }^{56}$ LOVATO, Luiz Gustavo. Ob. cit.

${ }^{57}$ CARVALHO, André Regis. Ob. cit., p. 89.
} 
Municípios, revertendo-a conforme não sejam atingidos determinados indicadores econômicos e sociais", indicando ainda a "possibilidade de fusão de municípios". 58

Em uma abordagem menos radical, será explorada mais adiante a solução consistente na constituição de consórcios públicos ou administrativos entre os Municípios. ${ }^{59}$

\subsection{Evolução histórica do federalismo cooperativo brasileiro}

Como se sabe, o federalismo brasileiro constituiu-se pela segregação de um Estado unitário, ao contrário do norte-americano, que, paradoxalmente, servira-nos de modelo, inspirando inclusive a opção por reservar as competências residuais aos Estados-membros - o que, diga-se de passagem, faz mais sentido quando todas as competências eram originalmente titularizadas por cada um destes. Não por acaso, o Estado brasileiro sempre relutou em admitir o grau de descentralização política e fiscal encontrado em outras federações.

Quando o Decreto n. ${ }^{\circ}$ 1, de 15 de novembro de 1889, instituiu a República Federativa no Brasil, não se tinha um quadro político e econômico muito diferente do que sustentara a centralização do período imperial (e particularmente do Segundo Reinado), garantidora do poderio das elites agroexportadoras, especialmente as do Sudeste, que se beneficiavam da ascensão da cultura cafeeira.

Foram essas mesmas elites, inicialmente interessadas na centralização estabilizadora, que acabariam contribuindo decisivamente para a implantação do sistema federativo, pondo em colapso o governo central sob as demandas por uma descentralização que concedesse às oligarquias estaduais maior autonomia. ${ }^{60}$

\footnotetext{
${ }^{58}$ RODRIGUES, Nina Trícia Disconzi. Novos rumos para o federalismo: contribuições para a sua melhoria. 2007. Tese (Doutorado) - Faculdade de Direito da Universidade de São Paulo, São Paulo, 2007. p. 238240.

${ }^{59}$ Cf. Capítulo 4 infra.

${ }^{60}$ CARVALHO, 2002, p. 81-82.
} 
A partir de então, a história política brasileira seria marcada por duas características: o movimento pendular de oscilação entre o federalismo centrípeto, que por vezes praticamente promoveu o retorno ao Estado unitário, e o federalismo centrífugo, mais aproximado do modelo dualista; ${ }^{61}$ e a consagração, já desde a Constituição de 1891 , de um terceiro nível de autonomia federativa, que seria mantido em todos os textos posteriores: o Município.

A primeira fase da Federação brasileira manteve-se essencialmente calcada no federalismo dualista clássico, praticamente ignorando a cooperação entre os entes federados. ${ }^{62}$ A Constituição de 1891 apenas permitia aos Estados "celebrar entre si ajustes e convenções sem caráter político", ou seja, de caráter administrativo, sujeitas à aprovação do Presidente da República (art. 65, n. ${ }^{\circ}$ 1, c/c art. 48, n. ${ }^{\circ}$ 16). Já a União só podia prestar auxílio aos Estados em situações excepcionais, a teor do art. $5^{\circ}$ da Lei Maior, que assim dispunha:

Art. $5^{\circ}$. Incumbe a cada Estado prover, a expensas próprias, às necessidades de seu governo e administração; a União, porém, prestará socorros ao Estado que, em caso de calamidade pública, os solicitar.

Se durante a Primeira República a força das oligarquias paulista e mineira afirmaram a dualidade da Federação, assegurando autonomia ao menos para os Estados mais abastados, após a Revolução de 1930, o enfraquecimento das elites do café-com-leite, que entravam em rota de colisão, dá ensejo a um impacto de autoritarismo, passando-se à fase do "federalismo pátrio". A centralização da capacidade de investimento e direção econômica ocasiona a disputa estadual e local por prestígio junto ao governo central, com vistas aos auxílios financeiros, ao mesmo tempo que solapa a autonomia constitucional e federativa das entidades subnacionais. ${ }^{63}$

\footnotetext{
${ }^{61}$ HORTA, Raul Machado. Tendências atuais da federação brasileira. Cadernos de Direito Constitucional e Ciência Política, São Paulo, v. 4, n. 16, p. 8, jul./set. 1996; DIAS, 2006, p. 56; e CAMPOS, 2006, p. 77.

${ }^{62}$ BERCOVICI, 2000, p. 119.

${ }^{63}$ CAMPOS, 2006, p. 76.
} 
Mas a derrocada do federalismo dual, antes mesmo de pavimentar os caminhos para a ascensão do autoritarismo, correspondeu a um fortalecimento da idéia de que os Estadosmembros precisavam atuar em um concerto harmônico, em prol da sobrevivência mesma do Estado federado. ${ }^{64}$

Nesse contexto, o advento da Constituição de 1934 introduziu o federalismo cooperativo, prevendo, em seu art. $9^{\circ}$, a faculdade de União e Estados "celebrarem acordos para a melhor coordenação e desenvolvimento dos respectivos serviços, e, especialmente, para a uniformização de leis, regras ou práticas, arrecadação de impostos, prevenção e repressão da criminalidade e permuta de informações". ${ }^{65}$

De outra parte, o art. 5,$\S 1^{\circ}$, da Constituição Federal de 1934 previa que "os atos, decisões e serviços federais serão executados em todo o País por funcionários da União, ou, em casos especiais, pelos dos Estados, mediante acordo com os respectivos Governos", enquanto o art. $7^{\circ}$, parágrafo único, estatuía poderem “os Estados, mediante acordo com o Governo da União, incumbir funcionários federais de executar leis e serviços estaduais e atos ou decisões das suas autoridades".

Os artigos 140 e 177 da Constituição de 1934 concretizavam a cooperação interfederativa, prevendo a competência da União para organizar o serviço nacional de combate às endemias, "cabendo-lhe o custeio, a direção técnica e administrativa nas zonas onde a execução do mesmo exceder as possibilidades dos governos locais". 66

No âmbito da distribuição de competências, o texto de 1934 deu também mais um passo em direção à efetivação da autonomia municipal, especificando, em seu artigo 13, o conteúdo dessa autonomia, desdobrada em autogoverno, prestação de serviços privativos e obtenção de rendas próprias. ${ }^{67}$ Já o art. 10 inaugurava a técnica de repartição que, como visto, ${ }^{68}$ tornar-se-ia marcante no federalismo brasileiro: a delimitação das competências legislativas concorrentes.

\footnotetext{
${ }^{64}$ BERCOVICI, 2000, p. 117-118.

${ }^{65}$ BERCOVICI, 2004, p. 39-40.

${ }^{66}$ BERCOVICI, 2000, p. 119-120.

${ }^{67}$ DIAS, 2006, p. 63.

${ }^{68}$ Cf. item 2.2 supra.
} 
No entanto, como é sabido, o sopro democrático da Constituição de 1934 teve efêmera vigência. A instalação do Estado Novo, em 10 de novembro de 1937, significou a quase supressão das autonomias federativas, decretando-se a intervenção federal em todos os Estados. ${ }^{69}$

Atinge-se nesse ponto o mais elevado grau de centralização que o federalismo brasileiro já conheceu, por meio de um controle econômico e militar, bem como de um sistema de administração única baseado no Departamento Administrativo do Serviço Público (DASP), responsável pela forte ingerência da União nos assuntos estaduais e locais.

A Carta de 1937 retirou a hipótese - prevista no art. $5^{\circ}, \S 1^{\circ}$, da Constituição Federal anterior - pela qual se permitia a execução de atos, serviços e decisões federais por agentes estaduais, estabelecendo apenas que "mediante acordo com o Governo federal, poderão os Estados delegar a funcionários da União a competência para a execução, de leis, serviços, atos ou decisões do seu governo" (art. 22). Sem dúvida nota-se aí uma opção política centralizadora, impedindo a delegação de atribuições federais a servidores estaduais, mas não o contrário.

O movimento centrípeto operado no Brasil por força da Constituição de 1937 teria representado, para diversos autores, o verdadeiro desaparecimento da Federação, tendo a carta ditatorial mantido o sistema apenas nominalmente, ${ }^{70}$ uma vez que, "durante todo o Estado Novo, não sobrou nenhuma esfera legislativa para que os Estados atuassem sem a permissão do Poder Central". ${ }^{71}$

A Constituição de 1946 reafirmou o federalismo cooperativo, que passou a ser enfocado sob uma nova perspectiva: a da redução das desigualdades regionais, mediante o planejamento e a coordenação de ações de alcance nacional. Surgia assim a busca oficial, a que se deu continuidade nas Constituições seguintes, pela "superação das desigualdades regionais", com a "harmonização interna do desenvolvimento nacional". 72

\footnotetext{
${ }^{69}$ BERCOVICI, 2004, p. 39-40.

${ }^{70}$ DIAS, 2006, p. 63.

${ }^{71}$ BERCOVICI, 2004, p. 42.

${ }^{72}$ Ibid., p. 43.
} 
Conforme discorremos há pouco, ${ }^{73}$ parece perfeitamente razoável afirmar a existência de uma relação proporcional entre a orientação política inspirada no Estado do Bem-Estar Social - sobretudo quando voltada, como no Brasil, para a superação de desigualdades regionais num território de dimensões continentais - e a percepção, por parte do Governo Central, de maior quantidade de competências, de modo a que este exerça um papel planejador e redistributivo no tocante à alocação de recursos e demarcação de prioridades. Sob a égide da ordem constitucional de 1946, parece ter sido precisamente esta a situação que se delineou.

Naquele período, como corolários da aludida preocupação com o desenvolvimento homogêneo do país, adotaram-se medidas como a transferência da capital brasileira para o Centro-Oeste e a criação de órgãos administrativos cujo objetivo era o de trabalhar para o progresso de determinadas regiões menos favorecidas, possibilitando sua integração nacional.

Segundo Raul Machado Horta,

o primeiro momento dessa tendência de desenvolvimento regional pode ser localizado na previsão contida no Ato das Disposições Constitucionais Transitórias da Constituição Federal de 1946, que impunha ao Governo Federal a obrigação de traçar e executar um plano de aproveitamento total das possibilidades econômicas do Rio São Francisco e seus afluentes. $^{74}$

Para o cumprimento não só desse preceito, como do princípio implícito de atuação cooperativa em prol da supressão dos desequilíbrios regionais, atuariam diversos órgãos federais criados a partir de então.

Com efeito, o traço mais marcante do federalismo cooperativo brasileiro nas décadas que se seguiram foi a institucionalização desses órgãos regionais destinados a promover o desenvolvimento de regiões consideradas problemáticas - assim entendidas

\footnotetext{
${ }^{73}$ Cf. item 2.1 supra.

${ }^{74}$ HORTA, 1996, p. 10.
} 
como as regiões desniveladas do restante do país em termos sociais e econômicos -, tornando concreta a cooperação interfederativa preconizada na teoria. Pode-se citar como principais exemplos desses órgãos a SUDENE (Superintendência do Desenvolvimento do Nordeste, criada pela Lei n. 3.692 , de 15.12.1959); a Comissão do Vale do Rio São Francisco (criada pela Lei n. ${ }^{\circ}$ 541, de 15.12.1948); a SUDAM (Lei n. ${ }^{\circ} 5.173$ - de 27.10.1966), criada sob o Plano de Valorização Econômica da Amazônia; a Superintendência do Vale do Rio São Francisco (Decreto-Lei n. ${ }^{\circ} 292$, de 28.02.1967); e a Companhia de Desenvolvimento do Vale São Francisco (Lei n. ${ }^{\circ} 6.088$, de 16.07.1974).

As aludidas entidades possuíam natureza autárquica, fazendo parte, todas elas, da administração indireta da União. As políticas de desenvolvimento regional não foram, assim, capitaneadas por entes territoriais autônomos, de âmbito regional, como se dera em países como a Espanha e a Itália, mas sim por órgãos federais, a exemplo do que ocorria também nos Estados Unidos. ${ }^{75}$ Sob esse aspecto, razão assiste a Gilberto Bercovici quando conclui que, "mesmo com a criação dos órgãos de desenvolvimento regional, a competência de planejar e implementar uma política de desenvolvimento regional é do Governo Federal", 76

Nessa altura, pelas circunstâncias expostas, o federalismo cooperativo brasileiro se colocava ante o debate a respeito da possibilidade ou não de que as políticas estaduais e municipais fossem coordenadas por entes federais. ${ }^{77}$ Haveria aí uma desmedida intrusão da União na recém-(re)conquistada autonomia dos Estados-membros e Municípios? A resposta não chegou a ser obtida. Tão logo a SUDENE pôs em prática uma fórmula para atenuar a intervenção federal - a representação estadual no Conselho Federativo da entidade -, o Golpe de 1964 jogou por terra, mais uma vez, o federalismo brasileiro. ${ }^{78}$

Mas a contribuição da ordem de 1946 para a cooperação federativa não se resumiu à criação dos órgãos de desenvolvimento regional, que, em grande parte, se perpetuariam mesmo na ditadura militar, mas também pelo estabelecimento de uma repartição de receitas tributárias relativamente benéfico a Estados e Municípios, aquinhoados com

\footnotetext{
${ }^{75}$ BERCOVICI, 2000, p. 224.

${ }^{76}$ Ibid., p. 225.

${ }^{77}$ Ibid., p. 225-226.

${ }^{78}$ Ibid., loc. cit..
} 
percentuais da arrecadação dos impostos que se tornaram objeto da repartição - técnica essa que inspiraria o constituinte de $1988 .^{79}$

De mais a mais, foi a Constituição de 1946 responsável pelo restabelecimento, ao menos em parte, da força administrativa dos Estados-membros, devolvendo, por meio do art. $18, \S 3^{\circ}$, a possibilidade de estes celebrarem acordo com a União para a execução de leis, serviços, atos e decisões federais.

Já a Carta de 1967, refletindo a recomposição das forças políticas da época, e seguindo à risca o movimento pendular que caracteriza nosso federalismo, representou novo retorno à centralização, avalizando um "federalismo puramente nominal e aparente". 80

$\mathrm{Na}$ época, instalou-se um quadro de profunda ingerência da União nos assuntos municipais, por meio de institutos como a Comissão Nacional de Política Urbana e o Fundo Nacional de Desenvolvimento Urbano, que significavam o enfraquecimento da autonomia municipal na exata medida em que garantiam a lógica federativa do modelo autoritário, calcado na realização do desenvolvimento com o controle das bases políticas, "ampliando o espaço de intervenção federal, limitando o raio de ação dos governos subnacionais". 81

Persistiram, nesse período, o intervencionismo e o dirigismo estatal que já se haviam consolidado sob a ordem anterior, concentrando na União o poder de direção nacional da economia, o qual aumentou ainda mais, após 1967, com a nova enumeração constitucional das competências privativas. ${ }^{82}$

Por um lado, a autonomia estadual pouco resistia frente à ditadura que se instaurava. Inúmeras normas de organização da União passaram a ser de observância

79 HORTA, 1996, p.16; RAMOS, Dircêo Torrecillas. O federalismo assimétrico. 2. ed. Rio de Janeiro: Forense, 2000. p. 52.

${ }^{80}$ HORTA, Raul Machado. Reconstrução do federalismo brasileiro. Revista de Direito Público, São Paulo, n. 64, p. 16, out./dez. 1982.

81 ABRÚCIO, Fernando Luiz; SOARES, Márcia Miranda. Redes federativas no Brasil: cooperação intermunicipal no Grande ABC. São Paulo: Fundação Konrad Adenauer, 2001. p. 101. (Série Pesquisas, n. 24).

${ }^{82}$ Ibid., p. 19. 
obrigatória pelos Estados-membros, que se limitavam a repeti-las, em suas Constituições meramente formais. ${ }^{83}$

De outro lado, o texto da Constituição, alterado pela Emenda n. ${ }^{\circ} 1 / 69$, retirava das capitais estaduais, estâncias hidrominerais e Municípios declarados de interesse da segurança nacional a prerrogativa de autogoverno, determinando a nomeação dos respectivos prefeitos pelo poder central. ${ }^{84}$

Do ponto de vista do federalismo cooperativo, conquanto o próprio federalismo estivesse em vias de extinção, verificaram-se aparentes avanços jurídicos que, no entanto, mal serviam para disfarçar a onipotência da União sobre todos os assuntos que tivessem alguma relevância para a política e a administração nacionais. A Carta de 1967 dispunha, genericamente, que:

Art. 13.

$[\ldots]$

$\S 3^{\circ}$ A União, os Estados e Municípios poderão celebrar convênios para execução de suas leis, serviços ou decisões, por intermédio de funcionários federais, estaduais ou municipais.

Já o art. 16, $\S 4^{\circ}$, dessa mesma Constituição, que seria eliminado pela Emenda Constitucional n. ${ }^{\circ} 1 / 69$, continha norma sobre cooperação entre municípios:

$\S 4^{\circ}$. Os Municípios poderão celebrar convênios para a realização de obras ou exploração de serviços públicos de interesse comum, cuja execução ficará dependendo de aprovação das respectivas Câmaras Municipais.

\footnotetext{
${ }^{83}$ HORTA, 1982, p. 21.

${ }^{84}$ DIAS, 2006, p. 64.
} 
Mesmo com a supressão desse último dispositivo, a ordem constitucional de 1967/69 favoreceu, sob os auspícios do supracitado art. 13, § 3º, a cooperação entre Municípios vizinhos, que, nos dizeres de Marcelo Caetano, dava-se com vistas à "realização de obras ou prestação de serviços de interesse comum". ${ }^{85}$

Mais que isso, o art. 164 da Constituição de 1967/69 já permitia que a União, por meio de lei complementar, e visando à "realização de serviços comuns", estabelecesse "regiões metropolitanas, constituídas por Municípios que, independentemente de sua vinculação administrativa, façam parte da mesma comunidade sócio-econômica". Tanto assim que a Lei Complementar n. ${ }^{\circ}$ 14/73 criou as regiões metropolitanas de São Paulo, Belo Horizonte, Porto Alegre, Recife, Salvador, Curitiba, Belém e Fortaleza, e a Lei Complementar n. ${ }^{\text {2 } 20 / 74}$ acrescentou a região metropolitana do Rio de Janeiro. Tais regiões, contudo, careciam de maior autonomia, uma vez que seu conselho deliberativo era presidido pelo Governador do Estado, sendo apenas o conselho consultivo composto pelos representantes municipais, tudo nos termos de lei estadual. ${ }^{86}$

Um novo estágio do federalismo brasileiro - e, particularmente, do nosso federalismo de cooperação - se iniciou com a promulgação da Constituição Federal de 1988.

A atual Lei Fundamental reafirmou o princípio federativo como postulado fundante e cláusula pétrea de nosso arranjo institucional, devolvendo aos entes federados os atributos inerentes à autonomia que os identifica como tais, e assinalando, de forma mais precisa do que se fazia até então, o espectro de competência, material e legislativa, de cada um deles. ${ }^{87}$ Além disso, a cooperação arquitetada pelo constituinte de 1988 representou ainda a intensificação da ajuda federal aos Estados, na forma de programas nacionais implementados principalmente por meio de convênios. ${ }^{88}$

No tocante aos Municípios, uma vez mais, na história do federalismo no Brasil, a evolução constitucional coloca em destaque seu estatuto jurídico e político, agora alçandoos inequivocamente ao patamar de componentes da estrutura federativa (art. $1^{\mathrm{o}}$, caput, e

\footnotetext{
${ }^{85}$ CAETANO, Marcelo. Direito constitucional. Rio de Janeiro: Forense, 1977. v. 2, p. 629.

${ }^{86}$ CAETANO, 1977, v. 2, p. 629-630.

${ }^{87}$ DALLARI, 2005.
} 
art. 18 da Constituição), dotados de auto-organização, ${ }^{89}$ embora seja digna de registro a resistência, por parte de alguns doutrinadores, a tal qualificação, pelo que continuam a reputar o Município como simples divisão territorial do Estado. ${ }^{90}$

Ademais, atinge-se, na atual ordem constitucional, um certo equilíbrio entre o dualismo da Federação, expresso na autonomia de União, Estados, Distrito Federal e Municípios, cada qual figurando como núcleo emissor de um ordenamento jurídico parcial, e a integração política nacional, representada pelo sistema de atribuição de competências comuns e concorrentes.

Diante do contexto descentralizador desenhado pela Constituição de 1988, era fundamental que não se permitisse o afastamento e a desarticulação dos entes federados, o que somente seria possível pela institucionalização de mecanismos aptos a emprestar a necessária coesão para a formulação das políticas públicas nos diferentes níveis. Nesse sentido, vislumbra-se particularmente nas competências comuns estipuladas no art. 23 a reafirmação, entre nós, desse necessário federalismo de cooperação, na medida em que a execução das tarefas lá enumeradas deve ser levada a efeito por todos os entes da Federação, indistintamente.

Coerente com o federalismo apresentado no caput, o parágrafo único do art. 23 é um dos dispositivos originários da Constituição de 1988 que mais claramente delineiam a possibilidade genérica de coordenação nacional das ações estatais, em prol do exercício das competências comuns enumeradas no mesmo artigo.

Há quem visualize no referido dispositivo um viés centralizador, sob o manto literal da previsão de cooperação interfederativa. Isso porque tal cooperação, a ser regida por lei complementar federal, não teria como não se submeter à observância das regras constitucionais de repartição de competências, particularmente as legislativas, que inegavelmente carregam certa preponderância da União. Assim, diversas tarefas a serem exercidas em cooperação, previstas entre as competências comuns dos entes federados,

\footnotetext{
${ }^{88}$ RAMOS, 2000, p. 49.

${ }^{89}$ BERCOVICI, 2004, p. 55-56; DIAS, 2006, p. 64.

${ }^{90}$ Entre outros, PINTO FERREIRA. Comentários à Constituição Brasileira. São Paulo: Saraiva, 1989. v. 1. p. 375, apud CARVALHO FILHO, José dos Santos. Consórcios públicos. Rio de Janeiro: Lumen Juris, 2009. p. 4.
} 
observarão normas gerais ou mesmo específicas editadas pela União, dada a competência legislativa concorrente ou, em alguns casos, privativa prevista para a matéria em questão. ${ }^{91}$

Fato é que o federalismo brasileiro, como visto, ${ }^{92}$ alcançou uma formatação contemporânea preponderantemente centralizadora. Nesse diapasão, qualquer tentativa de coordenação entre as diversas esferas de poder político passa necessariamente pela atuação eminente da União e o conseqüente enfrentamento do risco de desequilíbrio proveniente da própria opção constituinte. Em outras palavras, diante das normas de competência postas, não há como se promover uma integração nacional totalmente livre de reflexos na autonomia de Estados e Municípios. No entanto, deve-se enfatizar que isso não significa que a lei complementar mencionada no parágrafo único do art. 23 possa tolher ou restringir a titularidade das competências comuns por parte dos entes federados. ${ }^{93}$

Em uma perspectiva diametralmente oposta, Gilberto Bercovici nos dá notícia de que o movimento descentralizador operado pela Constituição ora em vigor chegou a ser visto por parte da doutrina como

um ressurgimento do 'federalismo estadualista', sem, no entanto, a
formação de um núcleo hegemônico de Estados como na Primeira
República. Este federalismo estadualista se caracterizaria pelo controle
das bancadas de deputados federais pelos Governadores e pela
competição predatória entre os Estados por mais recursos, por meio da $_{\text {guerra fiscal. }^{94}}$

No entanto, assim como o professor da Universidade de São Paulo, rechaçamos essa avaliação, uma vez que a autonomia reconquistada não se confunde necessariamente com um regresso à hegemonia dos poderes estaduais. Ao invés disso, a análise até aqui realizada, se permitiu extrair alguma conclusão sobre a preponderância de determinado

\footnotetext{
${ }^{91}$ ALMEIDA, 2005, p. 133.

${ }^{92}$ Cf. item 2.2 supra.

${ }^{93}$ BERCOVICI, 2004, p. 61.

${ }^{94}$ BERCOVICI, 2000, p. 121-122.
} 
nível federado na estrutura política brasileira, apontou para os resquícios de supremacia da União.

Quanto a outros aspectos do federalismo de cooperação, nota-se que a Constituição Federal de 1988, ao contrário de suas antecessoras, não mais previu a expressa autorização para a execução de leis e serviços de uma esfera federativa por funcionários de outra. Assim, se antes um acordo entre os entes federados podia proporcionar a execução de serviços de um deles por funcionários de outro, agora tal possibilidade não mais decorria de direta autorização constitucional. Em vez disso, passava a depender de normatização contida na lei complementar federal a que faz referência o art. 23, parágrafo único, da Lei Maior, ao menos em relação às competências comuns dos entes federados. No entanto, quanto às competências materiais privativas, já se defendia na doutrina a possibilidade de se celebrarem convênios permitindo a execução das leis e serviços políticos de um ente por outro, alternativa essa que, além de não ter sido vedada pela Constituição, ainda se amoldaria ao espírito dela. ${ }^{95}$

De qualquer forma, veio para aclarar as dúvidas sobre a existência ou não de uma previsão implícita da possibilidade de execução recíproca de leis e serviços a Emenda Constitucional n. ${ }^{\circ}$ 19/98, que retornou à orientação das constituições anteriores, ao dar ao art. 241 sua redação atual, como se verá mais adiante. ${ }^{96}$

No mais, é de se registrar que a Constituição brasileira traz, em várias passagens, claros sinais de receptividade ao federalismo cooperativo. Exemplo disso é o sistema educacional moldado pelos artigos $30, \mathrm{VI} ; 211$, caput e $\S \S 1^{\circ}$ e $4^{\mathrm{o}}$; e 214 , do texto constitucional:

Art. 30. Compete aos Municípios:

$[\ldots]$

VI - manter, com a cooperação técnica e financeira da União e do Estado, programas de educação infantil e de ensino fundamental;

$[\ldots]$

${ }^{95}$ ALMEIDA, 2005, p. 135-136. 
Art. 211. A União, os Estados, o Distrito Federal e os Municípios organizarão em regime de colaboração seus sistemas de ensino.

$\S 1^{\circ}$ A União organizará o sistema federal de ensino e o dos Territórios, financiará as instituições de ensino públicas federais e exercerá, em matéria educacional, função redistributiva e supletiva, de forma a garantir equalização de oportunidades educacionais e padrão mínimo de qualidade do ensino mediante assistência técnica e financeira aos Estados, ao Distrito Federal e aos Municípios;

$[\ldots]$

$\S 4^{\circ} \mathrm{Na}$ organização de seus sistemas de ensino, os Estados e os Municípios definirão formas de colaboração, de modo a assegurar a universalização do ensino obrigatório.

$[\ldots]$

Art. 214. A lei estabelecerá o plano nacional de educação, de duração plurianual, visando à articulação e ao desenvolvimento do ensino em seus diversos níveis e à integração das ações do Poder Público que conduzam à:

I - erradicação do analfabetismo;

II - universalização do atendimento escolar;

III - melhoria da qualidade do ensino;

IV - formação para o trabalho;

V - promoção humanística, científica e tecnológica do País.

O financiamento desse sistema integrado de ensino se dá igualmente sob a lógica do federalismo de cooperação, nos termos do art. 60 do Ato das Disposições Constitucionais Transitórias.

O federalismo cooperativo fica patente também no disposto no art. $39, \S 2^{\circ}$, da Constituição, com a redação dada pela Emenda Constitucional n. ${ }^{\circ}$ 19/98, segundo o qual:

\footnotetext{
${ }^{96}$ Cf. item 5.1 infra.
} 
Art. 39. A União, os Estados, o Distrito Federal e os Municípios instituirão, no âmbito de sua competência, regime jurídico único e planos de carreira para os servidores da administração pública direta, das autarquias e das fundações públicas.

\section{$[\ldots]$}

$\S 2^{\circ}$ A União, os Estados e o Distrito Federal manterão escolas de governo para a formação e o aperfeiçoamento dos servidores públicos, constituindo-se a participação nos cursos um dos requisitos para a promoção na carreira, facultada, para isso, a celebração de convênios ou contratos entre os entes federados.

Nota-se nessa passagem uma das poucas menções constitucionais expressas à contratação no âmbito interno da administração pública, e talvez a única à contratação entre entes federados. ${ }^{97}$

De outra parte, o art. 43 menciona as regiões, como sendo complexos geoeconômicos e sociais nos quais se pode articular o planejamento administrativo sob a responsabilidade da União, enquanto o art. $25, \S 3^{\circ}$, refere-se a regiões metropolitanas, aglomerações urbanas e microrregiões, a serem instituídas por lei complementar dos Estados.

Dinorá Adelaide Musetti Grotti noticia a polêmica, que já persiste há algumas décadas, no sentido de que o Estado, ao instituir tais regiões metropolitanas, aglomerações urbanas ou microrregiões, mediante lei complementar, "estaria usurpando competências municipais". Exemplo disso seria a Lei Complementar n. ${ }^{\circ}$ 87/97, do Estado do Rio de Janeiro. $^{98}$

A questão é de difícil solução, e seu desenlace refoge ao âmbito do presente estudo. De todo modo, pode-se considerar desde já a crítica como procedente sempre que a instituição de regiões, por meio de lei complementar estadual, faça-se acompanhar de um

\footnotetext{
${ }^{97}$ Cf. item 3.3 infra.
} 
planejamento unilateral, sem a participação de todos os entes envolvidos, ou mesmo de ações excessivamente interventivas em relação à autonomia administrativa municipal.

Mas as regiões metropolitanas, aglomerações urbanas, microrregiões e regiões de desenvolvimento integrado previstas nos artigos $25, \S 3^{\circ}$, e 43 da Constituição Federal não são as mais antigas, nem muito menos as únicas formas possíveis de coordenação regional no Brasil, consoante nos mostra a rica experiência prática dos Municípios brasileiros.

Fato é que, desde a implantação do federalismo no Brasil, notou-se a necessidade de um aparato administrativo que permitisse a efetivação das decisões tomadas em grau legislativo e de planejamento, sendo certo que, com a evolução do modelo de Estado, este

ampliou consideravelmente sua participação nas atividades sociais, estas se tornaram mais complexas, a evolução da tecnologia e o desenvolvimento das relações internacionais criaram novas possibilidades e acarretaram também novas necessidades, ou geraram situações absolutamente novas. ${ }^{99}$

Sob essa conjuntura formaram-se, ao longo dos anos, quase que espontaneamente, inúmeros convênios e consórcios administrativos, só recentemente consagrados no ordenamento posto sob as figuras do convênio de cooperação e do consórcio público.

O avanço da cooperação por intermédio da difusão do consorciamento intermunicipal vinha sendo apontado, mesmo antes da Lei n. ${ }^{\circ} 11.107 / 05$, que lhe concedeu tratamento jurídico sistematizado, como o próximo passo para a evolução do federalismo cooperativo, representando verdadeira expressão de uma "reengenharia federativa", hábil a fornecer novos meios para a prestação de serviços públicos. 100

Os consórcios públicos, ao lado de outras modalidades de cooperação entre entes da Federação, bem como, no dizer de Diogo de Figueiredo Moreira Neto, da noção de "leis

98 GROTTI, 2003, p. 92-93. Cf., sobre o assunto, a Ação Direta de Inconstitucionalidade n. ${ }^{\circ}$ 1.841-RJ, julgada em 18.06.1998.

${ }^{99}$ DALLARI, 2005.

${ }^{100}$ CARVALHO, 2002, p. 82, 95. 
federais nacionais" e "leis federais de aplicação restrita à União" e do conceito de "normas gerais", representam expressão do que se convencionou chamar neofederalismo brasileiro: um federalismo de cooperação distribuído em três graus. ${ }^{101}$

Impende analisar, a partir daqui, se a atual formatação jurídica dos consórcios públicos compatibiliza-se com o modelo federal adotado no Brasil, em especial no tocante ao equilíbrio e à harmonia entre as unidades federadas, diretrizes essenciais não só à estrutura do Estado brasileiro, mas à de qualquer Estado que se pretenda uma Federação.

${ }^{101}$ MOREIRA NETO, Diogo de Figueiredo. Curso de direito administrativo. 12. ed. Rio de Janeiro: Forense, 2001a. p. 30. 


\section{A REESTRUTURAÇÃo DA ADMINISTRAÇÃo PÚBLICA}

\subsection{Reforma administrativa}

Tem-se falado muito, nos últimos anos, de um movimento de redimensionamento da Administração Pública, cujo cerne seria, basicamente, a "contratualização da gestão pública". Com efeito, há décadas que se verifica, no direito administrativo ocidental, uma gradativa sucumbência do modo imperativo de agir da Administração, que se vai substituindo por uma atuação cada vez mais aberta à participação do administrado.

Nesse contexto, seria possível questionar a validade da velha contraposição entre o direito público, informado por normas cogentes, e, portanto, indisponíveis, e o direito privado, constituído por normas de caráter dispositivo, passíveis de flexibilização mediante o livre acordo das partes.

Se, de um lado, é certo que o século XX marcou o influxo de normas de ordem pública no direito privado, de outro pode-se identificar, atualmente, um movimento contrário, de migração de normas dispositivas para o direito público. Fato é que se assiste a uma interpenetração dos "direitos" público e privado, ramos esses que, longe de representarem compartimentos estanques da ciência jurídica, começam a confluir, exigindo do intérprete um esforço cada vez maior para distinguir os princípios aplicáveis aos casos concretos.

O mesmo movimento que tem levado o Estado a se abrir para uma administração participativa tem também acarretado uma reestruturação interna do modelo tradicional de administração. Como é sabido, nosso país, a exemplo do que sucedera em diversos outros no mundo ocidental, passou recentemente por uma assim chamada "reforma administrativa", consubstanciada na Emenda Constitucional n. ${ }^{\circ}$ 19/98, que, nos dizeres de muitos autores, marcou a transição - já ocorrente desde a segunda metade do século $\mathrm{XX}^{102}$ - da administração burocrática para a administração gerencial.

${ }^{102}$ DI PIETRO, 2008, p. 31. 
Da mesma forma que acontecera séculos antes, na transição do absolutismo para a administração burocrática, quando o foco de interesse da gestão pública passou do príncipe para o Estado, aos poucos as atenções da administração têm passado do Estado para o cidadão. ${ }^{103}$

Essa mudança foi motivada pela crítica que se fazia ao modelo anterior, crítica essa que mirava, em primeiro plano, o tamanho do Estado e sua excessiva burocracia: a hipertrofia da máquina administrativa, aliada ao exagero das formalidades exigidas por lei para a atuação estatal, causava sua própria ineficiência.

Não foi por outro motivo que se inseriu o princípio da eficiência ao lado dos demais princípios aplicáveis à administração pública, no caput do art. 37 da Constituição Federal. A impressão é que se quis deixar claro que a eficiência da administração agora é tão importante quanto a legalidade ou a moralidade. Tal constatação, levada ao extremo, permitiria concluir que, em certas hipóteses, quando houvesse conflito entre uma medida legal, mas não tão eficaz, e outra eficiente, embora ilegal, seria possível, ao menos em tese, que se prestigiasse esta em detrimento daquela. Esse é o raciocínio a que nos leva a teoria mais moderna dos princípios jurídicos, segundo a qual a solução de um conflito entre princípios constitucionais igualmente positivados se dá apenas no caso concreto, pela ponderação dos valores envolvidos; abstratamente, contudo, não se pode afirmar que um princípio prevaleça sobre o outro. ${ }^{104}$

Luiz Carlos Bresser Pereira, teórico que pode ser considerado um dos principais responsáveis pela implementação da reforma do Estado no Brasil, tendo-a conduzido na condição de titular do Ministério da Administração Federal e Reforma do Estado, identifica os seguintes aspectos no novo modelo de Administração: (1) a descentralização política, com a transferência de recursos e atribuições para as esferas políticas regionais e locais; (2) a descentralização administrativa, com a delegação de atribuições e concessão de maior autonomia para os administradores públicos; (3) redução dos níveis de hierarquia nas organizações públicas; (4) aumento da flexibilidade na administração pública, permitindo-se a multiplicidade e a competição administrada; (5) substituição da desconfiança total pela idéia de confiança limitada; (6) controle de resultados, e não passo

${ }^{103}$ CAMPOS, 2006, p. 41. 
a passo dos atos e procedimentos administrativos; (7) mudança do foco de atenção da administração, que deixa de ser o próprio Estado e passa a ser o cidadão. ${ }^{105}$

Assim é que, em nome da eficiência, a reforma do Estado brasileiro implantou, entre outras coisas, mecanismos de ampliação da autonomia dos entes públicos, rumo ao que já se denominou, conforme expusemos, ${ }^{106}$ de coordenação gerencial da administração pública.

\subsection{Administração Pública Gerencial}

A necessidade de coordenação das atividades administrativas é inerente à própria tarefa de administrar, e a preocupação com ela não representa novidade em nosso ordenamento. O Decreto-lei n. ${ }^{\circ}$ 200/67 dedica o Capítulo II do Título II a esse tema, referindo-se à Administração Federal. Mas a coordenação gerencial de que se trata agora alcança contornos mais amplos, envolvendo órgãos e entidades de todas as esferas de poder, além de particulares, e representa uma nova maneira de se entender a função administrativa do Estado, centrada antes na finalidade pública que na forma legal.

Assim é que essa nova perspectiva logrou intensificar a coordenação entre órgãos estatais e entre estes e órgãos não-estatais, de modo que novos institutos vêm sendo criados "com vistas ao aperfeiçoamento da eficiência e da ética na gestão dos interesses públicos". ${ }^{107}$ Para Diogo de Figueiredo Moreira Neto, derrubou-se a "mística da competência”, afastando-se a idéia de que a negociação de um pacto cooperativo implica renúncia a exercício da competência ou transferência de poder indelegável. ${ }^{108}$

\footnotetext{
${ }^{104}$ CANOTILHO, José Joaquim Gomes. Direito constitucional. 6. ed. Coimbra: Almedina, 1993. p. 456.

${ }^{105}$ PEREIRA, Luiz Carlos Bresser. Exposição no Senado sobre a reforma da Administração. Cadernos MARE da Reforma do Estado, Brasília: Ministério da Administração Federal e Reforma do Estado, v. 3, 1997.

${ }^{106}$ Cf. item 2.1 supra.

${ }^{107}$ MOREIRA NETO, Diogo de Figueiredo. Mutações do direito administrativo. 2. ed. Rio de Janeiro: Renovar, 2001b. p. 30, grifo do autor.

108 Ibid., loc. cit.
} 
Segundo o autor, a aludida coordenação se instala, então, nos âmbitos interno (cooperação) e externo (colaboração). Neste, apresenta como nota característica a gestão pública em parceria com os particulares. Naquele, destacam-se a autonomia gerencial e a gestão associada de atividades. ${ }^{109}$

A coordenação interna (cooperação) baseia-se, entre outras medidas, na descentralização de competências, dos órgãos centrais para os locais, da administração direta para a indireta. ${ }^{110}$

Sob o ponto de vista jurídico, o novo perfil da administração pública, menos imperativo e mais aberto ao consenso, fez reduzir o papel do ato administrativo, deixando que o conceito de atividade passasse a protagonista do direito administrativo, haja vista a modificação das funções públicas, cada vez menos compatíveis com a atuação pontual e unilateral do Estado, e cada vez mais exigentes da adoção de políticas públicas continuadas e participativas. $^{111}$

No direito administrativo, o fenômeno descrito se faz sentir principalmente na adoção de institutos como as parcerias público-privadas, os contratos de gestão, os termos de parceria, os termos de ajustamento de conduta celebrados pelo Poder Público, os convênios (sejam eles de delegação, cooperação ou colaboração) e, especificamente quanto à cooperação interna, os contratos de gestão previstos no art. $37, \S 8^{\circ}$, da Constituição, e os consórcios públicos. Pode-se afirmar que os consórcios são, nesse contexto, expoentes da cooperação administrativa no âmbito da coordenação gerencial da administração pública.

Mais que isso, nas palavras de Lílian Maria Salvador Guimarães Campos,

os consórcios públicos são instrumentos de relações intergovernamentais cooperativas, com potencial para superar assimetrias de capacidades e permitir o exercício das novas responsabilidades dos entes governamentais. ${ }^{112}$

\footnotetext{
${ }^{109}$ MOREIRA NETO, 1998, p. 42.

${ }^{110}$ CAMPOS, 2006, p. 45, 65.

${ }^{111}$ DIAS, 2006, p. 51.

${ }^{112}$ CAMPOS, 2006, p. 4.
} 
A guinada da filosofia administrativa pública rumo à adoção de conceitos e instrumentos gerenciais anteriormente mais afetos à iniciativa privada pode ser considerada uma reação ideológica ao modelo de Estado desenhado desde as Constituições mexicana de 1917 e alemã de 1919, esta conhecida como a Constituição de Weimar. Como é sabido, instauravam-se à época as diretrizes do Welfare State, ou Estado do Bem-Estar Social, preocupado em garantir aos seus cidadãos os direitos humanos de segunda geração - os direitos sociais, atendidos não mais pela simples abstenção do Poder Público, como se dava no período de confirmação dos direitos individuais (de primeira geração), mas pela efetiva atuação estatal.

As teorias que serviram de suporte à busca pela redução do papel do Estado, inspiradas nos estudos do austríaco Friedrich Von Hayek, e que acabariam inserindo na pauta das reformas a necessidade de se transportar para a máquina governamental as técnicas de gestão de que temos tratado neste tópico, tinham em comum a característica de acusarem a exaustão do sistema anterior, baseado na burocracia, o qual teria sido responsável pela concepção de um Estado inflado, exageradamente interventor, cuja manutenção representava um peso para o orçamento público e para o desenvolvimento econômico.

De fato, nota-se desde algumas décadas a crescente dificuldade - previsível, diga-se - por que passa o Estado para sustentar um regime eminentemente assistencialista, pautado na prestação universal das benesses vitais mínimas à população, não raro sem a contrapartida de um mecanismo contributivo que permitisse equilibrar as finanças frente às enormes despesas originadas da adoção desse modelo político. De outra parte, os agentes econômicos visivelmente ressentiam-se de um Estado mais ágil, mais eficiente, menos atuante no domínio econômico e mais concentrado em fornecer unicamente as bases regulamentares para o livre exercício das atividades de mercado pelos particulares, inclusive daquelas atividades que ficaram sob exclusiva responsabilidade do Poder Público na maior parte do século XX. 
Assim é que as modificações trazidas pelo chamado neoliberalismo redefiniram "o papel do Estado brasileiro e adotaram a descentralização como estratégia [...]". ${ }^{113}$ Nesse sentido, de acordo com Pedro Durão, o fortalecimento do chamado modelo de "Estado Mínimo" teria favorecido a integração regional e a cooperação administrativa. ${ }^{114}$

Segundo Diogo de Figueiredo Moreira Neto, com a derrocada do modelo socialista e do Estado do Bem-Estar Social ascende o "Estado Pluriclasse" como organização política dominante, trazendo à participação política não mais meramente o cidadão, mas a coletividade organizada em segmentos - daí o termo "pluriclasse". ${ }^{115}$ A sociedade pluralista, que decorre do cenário de mobilidades (social, financeira, da produção e da informação) identificado pelo autor, é "uma constelação de módulos de interesses diversificados em torno dos quais gravitam e se agregam, em câmbio permanente, os indivíduos e as entidades de sua criação". ${ }^{116}$

Surgem, sob o influxo da sociedade pluralista, novas diretrizes para as políticas públicas, tais como a subsidiariedade, a coordenação, a privatização, a publicização e a consensualidade. Esta última passa a ocupar o lugar da imperatividade, manifestando-se, ainda de acordo com Diogo de Figueiredo Moreira Neto, nos campos da produção das normas, da administração dos interesses públicos (pela cooperação e colaboração) e da solução de conflitos (pelas formas alternativas de composição). ${ }^{117}$

Daí a importância de se compreender tais reformas para se assimilar o contexto em que ganham força, em nosso ordenamento jurídico, os convênios e os consórcios públicos, institutos que, embora não sejam novos, têm recebido recentemente a tarefa de instrumentalizar, ao lado de outros mecanismos, a implementação das reformas apontadas.

Pouco se sabe, até aqui, se as privatizações e, de modo geral, o neoliberalismo conseguirão confirmar sua assim proclamada vocação de panacéia para todos os males do Estado. O que se tem de concreto é que, em muitos casos, o abandono do modelo

\footnotetext{
${ }^{113}$ HARGER, Marcelo. Consórcios públicos na Lei n. ${ }^{\circ}$ 11.107/05. Belo Horizonte: Fórum, 2007. p. 64.

${ }^{114}$ DURÃO, 2004, p. 35-47.

${ }^{115}$ MOREIRA NETO, 1998, p. 38-40.

${ }^{116}$ Ibid., p. 38.

${ }^{117}$ MOREIRA NETO, 2001b, p. 40-41. Para uma análise histórica das transformações por que passou o Estado, com a descrição mais precisa dos alicerces da Administração Pública Consensual, cf. CAMPOS, 2006, p. 3-4.
} 
burocrático tem significado um convite ao desvio da legalidade, supostamente em prol da corrida pela eficiência. Também parece conclusivo que a total ausência de intervenção estatal na economia é absolutamente inviável - vide a recém-deflagrada crise econômica que se faz sentir em todo o mundo capitalista, provocada, em grande parte, pela abstenção e permissividade estatais no sistema de crédito imobiliário norte-americano.

Acrescente-se a isso a observação de que parece um tanto simplista crer na implementação de técnicas empresariais como solução única para imprimir maior eficiência ao setor público, ainda mais quando isso possa implicar um pretexto para se escapar ao controle da lei. Ora, se de um lado é verdade que as estruturas empresariais tradicionalmente possibilitam o alcance de significativos resultados, freqüentemente com grande rapidez e qualidade, de outro lado não se pode afirmar que os procedimentos privados sejam sempre um modelo de probidade e transparência. Ao contrário, como nos mostram os recentes escândalos envolvendo gigantes multinacionais como a Enron, nos EUA, e a Parmalat, na Itália, a sujeição a auditorias privadas não é sinônimo de segurança e moralidade. E isso, em se tratando de dinheiro público, é sem dúvida preocupante.

Fato é que de nada adianta renovarem-se as técnicas de gerenciamento da administração pública se não se renova também o cuidado com que os agentes responsáveis pela implantação desses novos instrumentos agirão. Em outras palavras, afigura-se importante endossar o alerta feito por Diogo de Figueiredo Moreira Neto, de modo elogiável e quiçá inovador na literatura do direito administrativo brasileiro, no sentido de que, além de se promoverem alterações de estrutura e funcionamento do direito administrativo, é necessário, mais que isso, mudar a mentalidade dos administradores e dos usuários do serviço público. ${ }^{118}$ Vale dizer, a concepção finalística da administração não pode assumir o significado de que os fins justificam os meios.

É não apenas conveniente, mas fundamental, portanto, desenvolver os institutos de participação administrativa, tanto na tomada de decisão quanto na sua execução e controle. Isto porque o direito deve continuar progredindo sem, contudo, prejudicar as valiosas conquistas no sentido do que o autor denomina "aperfeiçoamento ético das relações humanas":

${ }^{118}$ MOREIRA NETO, 2001b, p. 34. 
sob tais premissas, não devem jamais, legisladores e administradores, deixarem-se seduzir pela promessa de algum tipo de êxito estatístico ou de atraente realização conjuntural em detrimento de um rigoroso travejamento jurídico, pois só pelo Direito se alcançarão vitórias duradouras sobre a insegurança e sobre a injustiça. ${ }^{119}$

Por fim, cumpre registrar que, ao contrário do que sustenta boa parte da doutrina, ${ }^{120}$ não enxergamos os consórcios públicos como manifestação da administração pública consensual, uma vez que não há sentido em se propor o consenso entre órgãos e entidades pertencentes ao Estado - seja porque os órgãos estatais têm uma vontade única, sob o ponto de vista jurídico, seja porque a necessidade de atuação conjunta e simétrica entre diferentes pessoas de um mesmo corpo político (o Estado brasileiro) decorre naturalmente da própria existência da Federação -, mas apenas entre este e particulares. De todo modo, é inegável que os consórcios frutificam num contexto de revisão do papel do Estado, inserindo-se definitivamente entre os instrumentos e técnicas da novel administração pública gerencial, que projetou as bases da administração consensual, mas com esta não se confunde.

3.3. Os acordos entre entes federados (associações de municípios, convênios de delegação, convênios de cooperação, consórcios)

O federalismo cooperativo brasileiro, otimizado pelos novos paradigmas da administração pública gerencial, tem propiciado os mais diversos arranjos entre os entes federados, que variam das tradicionais associações de municípios aos recentes consórcios públicos dotados de personalidade jurídica própria.

${ }^{119}$ MOREIRA NETO, 2001b, p. 35. Grifo do autor.

${ }^{120}$ Como o próprio MOREIRA NETO, 2001b, p. 42, além de HARGER, 2007, p. 28, e MEDAUAR, Odete; OLIVEIRA, Gustavo Justino de. Consórcios públicos: comentários à Lei 11.107/2005. São Paulo: RT, 2006, p. 33. No mesmo sentido, CAMPOS, 2006, p. 61 e 115, ressalta que "o consenso apresenta 
As associações de municípios destinam-se a representar os interesses das comunas junto às instituições em geral, como por exemplo o Congresso Nacional, da mesma forma que qualquer outra associação que congregue pessoas jurídicas de uma mesma categoria. Nesse sentido, não se confundem com instrumentos para a gestão associada de serviços públicos.

Os convênios são instrumentos destinados a auxiliar o Estado, notadamente, em dois importantes setores da atuação administrativa: o fomento e a prestação de serviços públicos. Quando celebrados com particulares, trata-se necessariamente de modalidade fomento, e nunca de delegação de serviços públicos, que não se pode dar por essa forma. ${ }^{121}$ E quando envolve entes públicos, converte-se em instrumento fundamental para a prestação de serviços públicos, seja por viabilizar o repasse de recursos materiais e financeiros à entidade incumbida de prestá-los, seja por permitir a gestão conjunta de tais serviços.

Numa acepção ampla, tem-se entendido que o

convênio de cooperação é um ato administrativo complexo, modalidade pública do gênero acordo, pelo qual entidades públicas ou privadas cooperam para a satisfação de um interesse público mútuo, (...) cujo resultado será, obrigatoriamente, comum. ${ }^{122}$

Embora seja esse, de fato, o conceito larga e indistintamente empregado na prática administrativa, e antes de adentrarmos na discussão sobre a natureza jurídica de tais ajustes, ${ }^{123}$ caberia traçar, aqui, uma classificação mais específica dos convênios, que permita a melhor compreensão do assunto. Já se disse que o Estado pode coordenar suas atividades interna e externamente, ou seja, a coordenação gerencial pode ser dividida, respectivamente, em cooperação e colaboração. Considerando-se que os convênios são,

condições de ser amplamente adotado, principalmente em contratos, convênios e consórcios”, sendo estes últimos, portanto, verdadeiros instrumentos da administração pública consensual.

${ }^{121}$ DI PIETRO, Maria Sylvia Zanella. Direito administrativo, 18. ed. São Paulo: Atlas, 2005b. p. 298.

122 DURÃO, 2004, p. 141.

${ }^{123}$ Cf. item 6.1.2 infra. 
provavelmente, a ferramenta mais utilizada para se empreender essa coordenação, seja com os particulares, seja com outros entes públicos, é natural que falemos, no primeiro caso, em convênios de colaboração, e, no segundo, em convênios de cooperação.

Sob outra perspectiva, pode-se identificar os convênios que têm por escopo transferir determinada atividade cujo exercício caberia, em princípio, ao ente que a transfere, e aqueles que objetivam a execução compartilhada de atribuições que competem a todos os conveniados. Naquela hipótese, trata-se de convênio de delegação. Nesta, poderíamos denominar por convênio de cooperação em sentido estrito.

O Decreto-lei n. ${ }^{\circ}$ 200/67, ao tratar da coordenação na Administração Federal, estabelece para esta a prioridade de firmar convênios com órgãos estaduais e municipais que exerçam as mesmas atividades (art. $9 .^{\circ}$, parágrafo único). Mais adiante, o convênio é previsto como instrumento de descentralização das atividades federais para os outros entes políticos (art. 10, $\S 1 .^{\circ}, b$ ). Além disso, o Decreto-lei determina que, em regra, "a execução de programas federais de caráter nitidamente local deverá ser delegada, mediante convênio, aos órgãos estaduais ou municipais incumbidos de serviços correspondentes" (art. 10, § 5..$^{\circ}$. O mesmo diploma legislativo prevê ainda a preferência pela celebração de convênios com entidades públicas e privadas para prestação de assistência médica (art. $\left.156, \S 2 .^{\circ}\right)$.

Conforme visto, ${ }^{124}$ a própria Constituição de 1967, desde sua redação original, que neste ponto se manteve com a Emenda Constitucional n. $.^{\circ} 1 / 69$, previa, em seu art. $13, \S 3^{\circ}$ - dando continuidade à tradição constitucional iniciada em 1934 -, a possibilidade de os entes federados celebrarem convênios "para execução de suas leis, serviços ou decisões, por intermédio de funcionários federais, estaduais ou municipais".

A Constituição Federal de 1988, ao omitir regra semelhante, deu ensejo a dúvidas quanto à possibilidade de os entes políticos conveniarem-se visando à execução recíproca das respectivas leis, serviços e decisões, dúvidas essas que só seriam definitivamente superadas com o advento da Emenda Constitucional n. ${ }^{\circ} 19 / 98 .^{125}$

\footnotetext{
${ }^{124}$ Cf. item 2.3 supra.

${ }^{125}$ Cf. item 2.3 supra.
} 
Antes mesmo dessa emenda, a regulação dos convênios contava com referências legislativas esparsas, como as presentes no ainda vigente Decreto-lei n. ${ }^{\circ}$ 200/67, já referido.

Até hoje, um dos dispositivos legais mais importantes em matéria de convênios é o art. 116 da Lei n. ${ }^{\circ}$ 8.666/93 (Lei de Licitações e Contratos Administrativos). ${ }^{126}$ Em contraponto à pormenorizada disciplina dos contratos administrativos, que ocupa a maior parte da lei, encontra-se no art. 116 a isolada menção aos convênios:

Art. 116. Aplicam-se as disposições desta Lei, no que couber, aos convênios, acordos, ajustes e outros instrumentos congêneres celebrados por órgãos e entidades da Administração.

Os parágrafos desse artigo tratam das formalidades e procedimentos exigidos para a celebração e execução de um convênio, quais sejam: a prévia aprovação de um plano de trabalho $\left(\S 1^{\circ}\right)$; a ciência a ser dada ao Poder Legislativo $\left(\S 2^{\circ}\right)$; as condições para liberação das parcelas do convênio $\left(\S 3^{\circ}\right)$; a utilização dos saldos de convênio $\left(\S 4^{\circ}\right)$; o aproveitamento das receitas auferidas com essa utilização dos saldos ( $\left.\S 5^{\circ}\right)$; e a devolução dos saldos financeiros à entidade ou órgão repassador dos recursos em caso de conclusão, denúncia, rescisão ou extinção do convênio $\left(\S 6^{\circ}\right)$.

A Lei n. ${ }^{\circ}$ 9.074/95 reporta-se aos convênios de cooperação em seu art. 36, autorizando o emprego de tais instrumentos para o credenciamento, por parte do poder concedente de determinados serviços, de Estados e Distrito Federal, a fim de que estes realizem "atividades complementares de fiscalização e controle dos serviços prestados nos respectivos territórios".

Já na Lei n. ${ }^{\circ}$ 9.277/96 encontra-se um exemplo bastante claro de convênio de delegação, tendo por objeto a transferência, da União para os demais entes federados, da

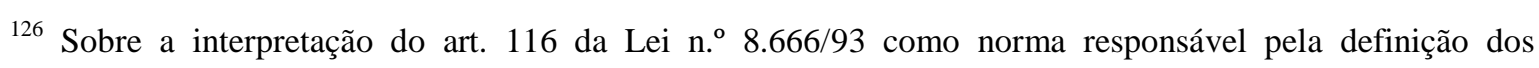
convênios em nosso ordenamento, distinguindo-os dos contratos, cf. item 6.1.2 infra. 
administração e exploração de rodovias e portos federais. Nos termos do art. $3 .^{\circ}$ dessa lei, “a delegação será formalizada mediante convênio". 127

Mais recentemente, a Lei n. ${ }^{\circ} 11.107 / 2005$ referiu-se, ainda que vagamente, aos convênios de cooperação, nos $\S \S 4 .^{\circ}$ e $5 .^{\circ}$ do art. 13 , ao tratar dos contratos de programa. ${ }^{128}$

Diversas outras leis federais mencionam, ainda que en passant, os convênios, tais como o Código Tributário Nacional (art. 83, parágrafo único; art. 100, IV; art. 102; art. 103, III; art. 199; art. 213; art. 214), a Consolidação das Leis do Trabalho (art. 14, caput e parágrafo único; art. 159), os Códigos de Pesca (art. 82), de Mineração (art. 1. ${ }^{\circ}, \S \S 1^{\circ}$ e $2^{\circ}$ ) e Florestal (art. 22) e a Lei criadora da Agência Nacional de Energia Elétrica (Lei n. ${ }^{\circ}$ $9.427 / 96$, art. $3^{\circ}$, IV)..$^{129}$

Também as constituições dos Estados brasileiros cuidaram de prever os convênios como instrumentos de gestão, tanto sob o aspecto da cooperação, quanto - e talvez mais freqüentemente - no campo da colaboração com o particular, em especial na área de saúde, em que se sobressai o fomento à atividade particular de interesse social. ${ }^{130}$

Em caráter ainda mais específico, pode-se registrar que, no âmbito do Estado de São Paulo, o Decreto n. ${ }^{\circ}$ 40.722, de 20 de março de 1996, com as alterações ditadas pelos Decretos n. ${ }^{\circ}$ 51.663, de 15 de março de 2007, e 52.245, de 9 de outubro do mesmo ano, dispõe sobre os requisitos para que o Governador autorize a celebração de convênios por parte dos órgãos a ele vinculados, bem como a estrutura formal que deve revestir o instrumento do ajuste. Além desse Decreto, pode-se mencionar outros que estipulam normas a respeito de convênios em assuntos específicos, como por exemplo o Decreto n. ${ }^{\circ}$ 93.872, de 23 de dezembro de 1986, que trata de aspectos financeiros dos convênios, e o Decreto n. ${ }^{\circ} 51.778$, de 26 de abril de 2007, que estabelece diretrizes para a celebração de convênios, pela Secretaria de Segurança Pública, “com Entidades Públicas ou Privadas

${ }^{127}$ Cf. também, sobre o assunto, a Instrução Normativa n. ${ }^{\circ}$ 46/2004 (art. 2. ${ }^{\circ}$, III), da Secretaria do Tesouro Nacional, sobre "convênios de delegação", bem como a Instrução Normativa n. 1/97, do mesmo órgão, sobre convênios em geral.

${ }^{128}$ Cf. item 8.9.2 infra.

${ }^{129}$ DURÃO, 2004, p. 73-75, com referência a diversas outras leis contendo normas sobre convênios.

${ }^{130}$ Para detalhes sobre o tratamento dos convênios nas constituições estaduais, cf. DURÃO, 2004, p. 67-71. 
para realização de objetivos de interesse comum, mediante mútua cooperação em atividades de segurança pública".

Já em relação aos consórcios, pouquíssimas são as referências normativas existentes antes de 2005, ano da promulgação da Lei de Consórcios Públicos. Elas serão examinadas no próximo capítulo.

Finalmente, no âmbito das relações cooperativas entre entes federados, caberia lembrar também a possibilidade, conhecida porém pouco estudada pela doutrina brasileira, de celebração de verdadeiros contratos entre entes federados, como os de concessão para exploração de determinados serviços públicos, além de inúmeros outros ajustes nos quais, pelo fato de os entes federados se colocarem em posição jurídica de igualdade, mais adequadamente incidem as regras de direito civil que as de direito administrativo. Um dos poucos exemplos desse tipo de contrato na nossa Constituição seria o do já mencionado art. $39, \S 2^{\circ}$, a respeito das escolas de governo para formação e aperfeiçoamento dos servidores públicos. ${ }^{131}$

Inversamente ao que aqui se dá, a contratação interadministrativa tem sido fartamente enfocada pela legislação e doutrina estrangeiras.

Na Espanha, parte da doutrina chegou a concluir que nas relações entre sujeitos públicos encontra-se terreno ainda mais propício para o fenômeno contratual que nas relações travadas entre o Poder Público e particulares, uma vez que a desigualdade jurídica existente nas relações público-privadas favoreceriam, em princípio, a edição de atos administrativos unilaterais. ${ }^{132}$

Quanto a tais contratos envolvendo entidades administrativas, enfatiza o autor espanhol Fernando Garrido Falla não se tratarem, necessariamente, de contratos administrativos, uma vez que a classificação deve ter em vista o objeto da avença, sendo assim "evidente la posibilidad de contratos civiles entre dos entes públicos". Tal hipótese inclusive encontraria acolhida na jurisprudência do Tribunal Supremo espanhol - sendo exemplo disso uma decisão de 7 de janeiro de 1936, na qual se declarara o caráter civil de

\footnotetext{
${ }^{131}$ Cf. item 2.3 supra.

${ }^{132}$ RODRÍGUEZ de SANTIAGO, 1997, p. 341.
} 
um contrato de arrendamento de um bem municipal ao Estado. ${ }^{133}$ Conquanto essa jurisprudência tenha sofrido revisão nos últimos anos, segundo noticia José María Rodriguez de Santiago, ${ }^{134}$ não haveria motivos - na opinião deste último autor - para se negar a possibilidade de sujeitos públicos celebrarem contratos privados, desde que estes se apresentem totalmente desconectados das suas competências administrativas, algo que só ocorre excepcionalmente.

Naquele país, já se enfrentou a problemática da aplicação da teoria dos contratos administrativos aos acordos celebrados entre entes federados, conforme estes detenham ou não a mesma titularidade sobre o serviço objeto de prestação associada. Ora, se no contrato administrativo incide o regime excepcional pelo qual uma das partes conserva suas prerrogativas sobre o serviço público, essa situação de privilégio não se justifica no ajuste em que as entidades contratantes ostentam a mesma titularidade sobre o serviço. ${ }^{135}$ Por isso, Rafael Entrena Cuesta traça a distinção entre contrato de colaboração e contrato de cooperação, sendo que, naquele, apenas uma das partes é titular do serviço público, verificando-se assim a desigualdade a justificar um regime exorbitante, e, neste, ambos os contratantes têm competência sobre o serviço, estando em situação de igualdade, de modo que não se recomenda usar a expressão "contrato administrativo", mas "contrato público". ${ }^{136}$ É sob essa perspectiva que a lei de contratações administrativas espanhola prevê expressamente o contrato de concessão de obra pública entre sujeitos públicos ${ }^{137}$ hipótese essa que, no mais, é conhecida também na prática brasileira.

Na Argentina, José Roberto Dromi define a relação jurídica interadministrativa como sendo "aquella que vincula a dos o más personas jurídicas públicas estatales (Nación, provincia, municipio, entidades autárquicas, empresas del Estado, sociedades del

${ }^{133}$ GARRIDO FALLA, Fernando. Tratado de derecho administrativo. 10. ed..Madrid: Tecnos, 1989. v. 2, p. 53-54.

${ }^{134}$ RODRÍGUEZ de SANTIAGO, op. cit., p. 360.

${ }^{135}$ GARRIDO FALLA, op. cit., p. 54.

136 ENTRENA CUESTA, Rafael. Consideraciones sobre la teoría general de los contratos de la administración. Revista de Administración Pública, Madrid, n. 24, p. 72, 1957. Note-se que a distinção feita pelo autor entre "contrato de cooperação" e "contrato de colaboração" não se confunde com a que viemos de fazer neste mesmo item entre convênios de cooperação e convênios de colaboração, nem com a diferenciação assinalada no item 3.2 supra entre a cooperação e a colaboração na atividade administrativa coordenada.

${ }^{137}$ RODRÍGUEZ de SANTIAGO, 1997, p. 364-365. 
Estado, etc.) o no estatales (cuerpos intermedios, corporaciones públicas, etcétera)" ${ }^{138}$ As relações podem envolver entes da mesma esfera de governo (nacional, provincial ou municipal) ou de distintas esferas (Nação e província, Nação e município, província e município).

Entre nós, diferentemente do que se passou na Espanha e na Argentina, nunca contamos com a expressa previsão legal de um contrato interadministrativo envolvendo a prestação associada de serviços públicos, ao menos até o advento da Lei n. ${ }^{\circ} 11.107 / 05$. Até então, os instrumentos tradicionalmente utilizados eram os convênios e consórcios administrativos.

Ainda assim, encontram-se, na doutrina pátria, menções ao contrato de direito público interno, que

\begin{abstract}
se caracteriza principalmente pelo contrato administrativo, subdividido em diversos tipos, tais como: (contrato de concessão de serviço público, contrato de obras públicas, contrato de prestação de serviços de fornecimento, contrato de empréstimos públicos), e, ainda, os convênios e consórcios [...]. ${ }^{139}$
\end{abstract}

Hoje em dia, os convênios de cooperação, assim como os consórcios públicos, prestam-se a operacionalizar a gestão de serviços públicos em associação entre entes federados. No entanto, os primeiros se apresentam como institutos muito menos sólidos e complexos que os consórcios.

A uma, porque a formalização dos consórcios públicos passou, com o advento da Lei Federal n. ${ }^{\circ} 11.107 / 05$, a ser substancialmente mais intrincada que a dos convênios. A duas, porque a celebração de um consórcio público, ao contrário da de um convênio, implica a constituição de uma pessoa jurídica. E em terceiro lugar, porque os consórcios

\footnotetext{
${ }^{138}$ DROMI, 1996, p. 498.

139 DEO, Marta Luiza Reimão de. Contratos, convênios e consórcios na prática da administração pública brasileira: paralelo. EDP: Estudos de Direito Público, São Paulo, v. 5, n. 9, p. 71-72, jul./dez. 1986.
} 
aproximaram-se muito mais da roupagem de contratos, na mesma proporção em que se distanciaram do modelo convenial de ajuste.

Assim, os convênios de delegação e de cooperação revelam-se uma forma simplificada, todavia menos estável, de transferência e gestão associada de serviços públicos. $^{140}$

Odete Medauar e Gustavo Justino de Oliveira observam que a menor estabilidade conferida pelo tratamento normativo dos convênios parece contrastar com o fato de a Lei n. ${ }^{\circ} 11.107 / 05$ ter tornado ato de improbidade administrativa celebrar contrato "ou outro instrumento que tenha por objeto a prestação de serviços públicos por meio da gestão associada sem observar as formalidades previstas na lei" (art. 18, que acrescentou um inciso ao art. 10 da Lei n. ${ }^{\circ}$ 8.429/92). ${ }^{141}$ No entanto, temos que tal dispositivo, interpretado sistematicamente, só pode se referir, em primeiro plano, às formalidades previstas naquela mesma lei para a concretização dos consórcios públicos e contratos de programa, e apenas mediatamente àquelas previstas no ordenamento para a formalização de "outros instrumentos" - como os convênios de cooperação -, as quais, embora sejam menos complexas, nem por isso podem ser desprezadas (vide, por exemplo, o art. 116 da Lei n. ${ }^{\circ}$ $8.666 / 93)$.

${ }^{140}$ O Supremo Tribunal Federal já decidiu que "pela sua precariedade, os beneficiários do convênio administrativo não têm direito à sua manutenção, nem muito menos direito adquirido a ela." (RE 119.256SP, rel. Min. Moreira Alves, DJ 29/05/1992).

141 MEDAUAR, Odete; OLIVEIRA, Gustavo Justino de. Consórcios públicos: comentários à Lei 11.107/2005. São Paulo: RT, 2006. p. 110. 


\section{DELINEAMENTO HISTÓRICO DOS CONSÓRCIOS PÚBLICOS}

\subsection{Evolução jurídica}

A análise do surgimento e evolução dos consórcios no Brasil pode ser enfocada, sob determinados aspectos, à luz da história recente dos modos de prestação de serviços públicos. Isso porque o instituto consorcial sempre teve, entre nós, a conotação de instrumento alternativo para a prestação de serviços públicos, conotação esta que se reforçou com as inovações operadas nos últimos anos no ordenamento jurídico brasileiro. $^{142}$

Como é cediço, os modos pelos quais o Estado presta serviço público passaram por inúmeras modificações desde fins do século XIX. Em brevíssima síntese, seria possível dizer que o Estado passou de prestador direto dos serviços a concedente, delegando a execução, num primeiro momento, a particulares, e, posteriormente, descentralizando a prestação para entidades que criava no interior de sua estrutura administrativa, entidades essas que ora ostentavam personalidade jurídica de direito público, ora de direito privado.

Num terceiro momento, o Estado volta a repassar a execução dos serviços à iniciativa privada, seja alienando o controle das empresas estatais, seja atuando em parceria com os particulares - fala-se aí na "privatização", em sentido amplo. ${ }^{143}$

Hoje a doutrina brasileira enumera quatro diferentes maneiras pelas quais o Estado se desincumbe da prestação de serviços públicos: a prestação direta; a prestação por meio das entidades estatais descentralizadas; a prestação por meio de delegação a particulares; e a gestão associada de serviços públicos, modalidade esta que mais nos interessa para o escopo deste trabalho. ${ }^{144}$

\footnotetext{
${ }^{142} \mathrm{O}$ conceito de serviço público será mais detidamente examinado no item 8.2.1 infra. Para os objetivos deste capítulo, basta recorrermos à noção de serviço público como atividade prestacional da Administração Pública submetida a regime jurídico preponderante de direito público.

${ }^{143}$ DI PIETRO, 2008, p. 57-58.

${ }^{144}$ HARGER, 2007, p. 65; MEDAUAR; OLIVEIRA, 2006, p. 62-63.
} 
No Brasil, a evolução dos modos de prestação de serviços públicos acompanhou as progressivas mudanças do federalismo, o qual conheceu, já na década de 1930, a concretização de sua versão cooperativa - antes mesmo, portanto, da sistematização teórica do federalismo de cooperação -, por meio da gradual institucionalização dos consórcios administrativos.

O assunto foi inaugurado na legislação brasileira em 16 de dezembro de 1935, com a promulgação da Lei n. ${ }^{\circ} 2.484$, do Estado de São Paulo. ${ }^{145}$

A Carta de 1937 traz a primeira menção constitucional expressa a consórcios intermunicipais, inclusive reconhecendo-lhes personalidade jurídica:

Art 29. Os Municípios da mesma região podem agrupar-se para a instalação, exploração e administração de serviços públicos comuns. O agrupamento, assim constituído, será dotado de personalidade jurídica limitada a seus fins.

Parágrafo único. Caberá aos Estados regular as condições em que tais agrupamentos poderão constituir-se, bem como a forma, de sua administração.

As Constituições de 1946 e 1967/69 omitiram o termo "consórcio", embora contivessem, como visto, ${ }^{146}$ preceitos reveladores da adoção do federalismo cooperativo.

José Cretella Júnior faz um apanhado da legislação vigente sob o ordenamento de 1967/69, destacando o art. 16, § 4º da Carta de 1967, que facultava aos Municípios celebrarem convênios "para a realização de obra ou exploração de serviços públicos de interesse comum". ${ }^{147}$ Tal previsão foi suprimida pela Emenda Constitucional n. ${ }^{\circ} 1$, de 17 de outubro de 1969, mas não se podia dizer que os convênios e consórcios intermunicipais

\footnotetext{
${ }^{145}$ CRETELLA JÚNIOR, José. Direito administrativo municipal. 2. ed. Rio de Janeiro: Forense, 1981. p. 87.

${ }^{146} \mathrm{Cf}$. item 2.3 supra.

${ }^{147}$ Ibid., p. 87.
} 
estivessem banidos do ordenamento: ao contrário, os institutos já se encontravam definitivamente integrados "no sistema constitucional e administrativo brasileiro". ${ }^{148}$

No Estado de São Paulo, a Constituição de 1969 falava expressamente, em seu art. 104, na possibilidade de os Municípios se associarem em consórcios, nos seguintes termos: ${ }^{149}$

Os Municípios poderão realizar obras, serviços e atividades de interesse comum, mediante convênios com entidades públicas ou particulares, bem como através de consórcios municipais, utilizando-se dos meios e instrumentos adequados à sua execução.

De outra parte, as Leis Orgânicas dos Municípios paulistas invariavelmente contemplaram os consórcios intermunicipais, desde a Lei n. ${ }^{\circ}$ 9.205/65, cujo art. 51 permitia o consorciamento para a realização de obras e serviços de interesse comum, dispositivo esse repetido na Lei n. ${ }^{\circ}$ 9.842/67 (art. 54) e no Decreto-lei Complementar n. ${ }^{\circ}$ 9/69 (art. 70). ${ }^{150}$

Também sob o ordenamento de 1967/69, a Lei Orgânica dos Municípios do Espírito Santo previa expressamente, em seu art. 126, § $1^{\circ}$, os consórcios intermunicipais, que por sua vez eram chamados de "uniões de Municípios" pela Lei Orgânica vigente no Estado do Pará. ${ }^{151}$

A Constituição de 1988 não previa, em sua redação original, os consórcios, que somente seriam contemplados com o advento da Emenda Constitucional n. ${ }^{\circ} 19$, de 04 de junho de 1998.

Dentre as normas federais infraconstitucionais existentes a respeito do tema, as principais talvez sejam as constantes da Lei n. ${ }^{\circ} 8.080 / 90$, cujo art. 10 , caput e $\S 1^{\circ}$,

\footnotetext{
${ }^{148}$ CRETELLA JÚNIOR, 1981, p. 87-88.

${ }^{149}$ Ibid., p. 88.

${ }^{150}$ Ibid., loc. cit.

${ }^{151}$ CAETANO, 1977, v. 2, p. 629.
} 
merecem transcrição, haja vista sua relevância como raro norte regulatório da prática consorcial até 2005:

Art. 10. Os municípios poderão constituir consórcios para desenvolver em conjunto as ações e os serviços de saúde que lhes correspondam.

$\S 1^{\circ}$ Aplica-se aos consórcios administrativos intermunicipais o princípio da direção única, e os respectivos atos constitutivos disporão sobre sua observância.

A Lei n. ${ }^{\circ}$ 9.277/96, por sua vez, permite que a delegação da administração e exploração de rodovias ou a exploração de portos federais, a ser concretizada mediante convênio, tenha como destinatário um consórcio (art. $1^{\circ}$ ).

De outra banda, e em alguns casos já sob influência da Emenda Constitucional n. ${ }^{\text {o }}$ 19/98, que insere o tema no art. 241 da Constituição Federal, ${ }^{152}$ vários Estados preocuparam-se em dedicar dispositivos de suas constituições aos consórcios. Com efeito, a expressão "consórcio" é utilizada em dezesseis constituições estaduais, dentre as quais as da Bahia (art. 10), Espírito Santo (art. 276) e Pernambuco (art. 97, § 2º , que mencionam especificamente o "consórcio público", inclusive consignando a finalidade de gestão associada de serviços públicos. As constituições de Amapá, Bahia, Ceará, Espírito Santo, Goiás, Mato Grosso, Mato Grosso do Sul, Rio de Janeiro, Rondônia, Santa Catarina, São Paulo e Tocantins prevêem o consórcio intermunicipal ou interestadual, e as cartas de Minas Gerais, Paraná e Sergipe simplesmente utilizam o termo "consórcio". ${ }^{153}$

No Município de São Paulo, a atual Lei Orgânica prevê os consórcios em seu art. 13, XV, ao tratar da competência da Câmara para autorizar sua instituição. ${ }^{154}$

\footnotetext{
${ }^{152}$ Cf. item 5.1 infra.

${ }^{153}$ DURÃO, 2004, p. 71.

${ }^{154}$ Sobre a necessidade de autorização legislativa para a formalização de consórcios, cf. item 7.4 infra.
} 


\subsection{Experiência brasileira dos consórcios administrativos}

Os consórcios intermunicipais, entendidos em sentido amplo como pactos de cooperação celebrados entre dois ou mais Municípios, já se vêm proliferando há décadas. Sob a égide da Lei Estadual n. ${ }^{\circ}$ 2.484/35, tem-se notícia de que diversas municipalidades da região de Araraquara conjugaram esforços constituindo o "Consórcio da Alta Araraquarense". 155

Similarmente, vários Municípios da baixada santista e do litoral sul do Estado de São Paulo instituíram consórcios administrativos com vistas a enfrentar problemas comuns de saneamento e urbanismo. ${ }^{156}$

Foi, no entanto, a partir da reconquista de autonomia municipal encetada nos anos 80 que o consorciamento intermunicipal ganhou maior relevância na prática da administração pública brasileira, ${ }^{157}$ tendo-se chegado a afirmar que

o marco do desenvolvimento de consórcios públicos repousa na período 1984-1990, quando foi instituído o maior número de aglomerações do gênero, especialmente no Estado de São Paulo. ${ }^{158}$

A proliferação de consórcios teve a ver principalmente com a redemocratização do país, que devolveu aos entes federados grande parte da autonomia que haviam perdido durante o regime militar, tendo resultado num incentivo à maior atuação e articulação das ações em nível local. Além disso, a descentralização empreendida, que concedeu às edilidades não só a liberdade de organização política e administrativa, mas também maior autonomia financeira advinda da partilha obrigatória da arrecadação tributária por meio

\footnotetext{
155 CRETELLA JÚNIOR, 1981, p. 87.

${ }^{156}$ Ibid., loc. cit.

${ }^{157}$ CARVALHO, 2002, p. 91.

158 BARROS, Pedro Motta. Consórcio intermunicipal: ferramenta para o desenvolvimento regional. São Paulo: Alfa-Ômega, 1995, p. 61, apud DIAS, 2006, p. 91.
} 
dos fundos de participação, estimulou, como vimos, ${ }^{159}$ a criação de diversos novos Municípios. ${ }^{160}$ Em consequiência disso, para Solange Gonçalves Dias, o Brasil passa a se distinguir "pela existência de elevado número de pequenas comunas, com reduzida densidade econômica, dependentes de transferências fiscais e sem tradição administrativa e burocrática". 161

As dificuldades enfrentadas pelos Municípios recém-criados, que não apresentavam sequer condições de administrar e exercer as competências que lhes foram constitucionalmente outorgadas, acabariam sendo paulatinamente contornadas, em grande parte, pela "criação de consórcios intermunicipais voltados para a racionalização dos recursos de várias prefeituras localizadas numa mesma área geográfica". ${ }^{162}$

Segundo dados do Instituto Brasileiro de Geografia e Estatística - IBGE, registravam-se, em 2002, cerca de 5.283 declarações de consorciamento administrativo intermunicipal, sendo 2.169 na área da saúde. ${ }^{163} \mathrm{O}$ número impressiona, considerando-se que existem em nosso país, atualmente, 5.560 Municípios.

Nota-se, destarte, que a ausência de regras claras no ordenamento, que emprestassem aos consórcios, por exemplo, maior estabilidade jurídica, não se mostrou um empecilho para a disseminação do instituto, ao menos em nível municipal. ${ }^{164}$ Ao revés, seria de todo lícito asseverar que, antes mesmo do advento de qualquer marco regulatório, criou-se, entre nós, uma tradição de consorciamento, imposta pela necessidade de se buscar uma economia de investimentos, acompanhada de uma otimização da produção e uma redução das perdas. Para se entender a importância da parceria intermunicipal no Brasil, basta lembrar que ainda hoje a grande maioria dos nossos Municípios tem uma população

\footnotetext{
${ }^{159}$ Cf. item 2.2 supra.

${ }^{160}$ DIAS, 2006, p. 68-69.

${ }^{161}$ Ibid., p. 70-71.

${ }^{162}$ CARVALHO, 2002, p. 91.

163 INSTITUTO BRASILEIRO DE GEOGRAFIA E ESTATÍSTICA (IBGE). Pesquisa de informações básicas municipais: MUNIC, 2002. Disponível em: <http://www.rzoconsultoria.com.br/noticias.php?id=47>. Acesso em: 30 dez. 2007. Não há, nesse levantamento, estatísticas a respeito de consórcios interestaduais. Para pesquisa realizada após o advento do novo estatuto consorcial, cf. item 11.1 infra.

164 A respeito do funcionamento, na prática, dos institutos do convênio e do tradicional consórcio administrativo, cf. o detalhado estudo de DURÃO, 2004, p. 107-122.
} 
inferior à de muitos bairros da cidade de São Paulo, dispondo de orçamentos irrisórios e, não raro, administradores inexperientes e tecnicamente mal-preparados. Essas circunstâncias têm levado naturalmente as comunas a unir esforços e compartilhar experiências, conhecimento, tecnologia e recursos de todo tipo, valendo-se do consórcio como ferramenta de maximização da eficiência nas administrações públicas.

Ainda assim, a experiência vinha demonstrando que muitos desses consórcios obtinham resultados aquém do esperado, tendo alguns deles chegado a fracassar em sua missão, por conta de sua fragilidade jurídico-institucional. Tais constatações foram aos poucos levando ao surgimento de demandas por normas jurídicas que assegurassem a todos o conhecimento e domínio das regras do jogo e que, por sua vez, permitissem uma difusão ainda mais acentuada dos consórcios administrativos. ${ }^{165}$

Nesse sentido, pode-se enxergar a principal explicação para a grande quantidade de consórcios na área de saúde na promulgação da Lei n. ${ }^{\circ}$ 8.080/90, cujo art. 10 previa a possibilidade de os municípios constituírem consórcios "para desenvolver em conjunto as ações e os serviços de saúde que lhes correspondam”.

Não se está a afirmar, evidentemente, que antes da normatização do instituto fosse vedado aos entes federados atuarem em consórcio. Tal possibilidade decorria do próprio federalismo cooperativo consagrado pela Constituição, bem como da independência do Poder Executivo para promover as políticas públicas - o que é sua função essencial -, sem depender de expressa permissão legal para tanto. ${ }^{166}$ Ainda assim, é forçoso admitir que os administradores brasileiros parecem ter encontrado maior segurança e, em conseqüência, maior incentivo, para firmarem consórcios a partir da explícita previsão legal.

Após a promulgação da Emenda Constitucional n. ${ }^{\circ}$ 19/98, que introduziu um dispositivo específico sobre consórcios na Constituição Federal (art. 241), foi possível perceber mais um considerável salto na criação de consórcios administrativos, dotados ou não de personalidade jurídica. ${ }^{167}$

\footnotetext{
${ }^{165}$ DIAS, 2006, p. 93-94.

${ }^{166}$ Sobre a inconstitucionalidade da exigência de autorização legislativa para celebração de convênio pelo Executivo, cf. item 7.4 infra.

${ }^{167}$ CAMPOS, 2006, p. 85.
} 
Todavia, só mais recentemente, a Lei Federal n. ${ }^{\circ}$ 11.107, de 06 de abril de 2005, veiculou o que se pode considerar o reclamado marco regulatório dos consórcios públicos, conferindo-lhes formatação jurídica absolutamente nova. Importa perquirir, agora, se a lei tem condições de propiciar a segurança jurídica que se reclamava ou se, ao contrário, presta-se a gerar mais dificuldades do que soluções. 


\section{ATUAL REGRAMENTO JURÍDICO DOS CONSÓRCIOS PÚBLICOS}

\section{$\underline{5.1 . ~ B a s e s ~ c o n s t i t u c i o n a i s ~}$}

A possibilidade de cooperação entre as diversas esferas da Federação decorre naturalmente do modelo de federalismo cooperativo que vem sendo implantado em nosso país. O respeito à autonomia dos entes federados engloba a liberdade dada a estes de se desincumbirem de suas competências da maneira que lhes parecer mais adequada; trata-se de escolhas próprias do campo político.

Nesse sentido, e tendo-se em conta a farta experiência prática dos consórcios no Brasil, o Deputado Prisco Viana, relator da Proposta de Emenda Constitucional n. ${ }^{\text {1 }}$ 173/95 na Comissão de Constituição e Justiça (CCJ) da Câmara dos Deputados, manifestou-se

pela desnecessidade da edição de norma constitucional prevendo os consórcios públicos. ${ }^{168}$

Em princípio, para a concretização da coordenação interfederativa, basta que se conte com preceitos constitucionais genéricos a demonstrarem a opção pela cooperação entre os entes federados, donde se pode extrair o alicerce jurídico para o exercício associado das referidas competências.

Expressão desse federalismo cooperativo é o art. 23 da Constituição Federal, cujo parágrafo único dispunha originalmente que "lei complementar fixará normas para a cooperação entre a União e os Estados, o Distrito Federal e os Municípios, tendo em vista o equilíbrio do desenvolvimento e do bem-estar em âmbito nacional”.

Com a Emenda Constitucional n. ${ }^{\circ}$ 53/2006, foi introduzida uma modificação no texto desse dispositivo, substituindo-se o trecho "lei complementar fixará" por "leis complementares fixarão". Difícil entender o motivo da alteração, bem como seu alcance, mormente porque o tema da emenda era a educação, e seu objeto principal, a instituição do Fundo de Manutenção e Desenvolvimento da Educação Básica e de Valorização dos

${ }^{168}$ DIAS, 2006, p. 98. 
Profissionais da Educação, em substituição ao então existente Fundo de Manutenção e Desenvolvimento do Ensino Fundamental e de Valorização do Magistério.

Parece que o constituinte derivado quis aproveitar a oportunidade para deixar claro que não é proibida a edição de mais de uma lei complementar sobre cooperação, tendo em vista a ampla gama de matérias tratadas naquele art. 23. Entretanto, não se afigura razoável entender que o dispositivo se refere à promulgação de lei complementar de cada um dos entes federados sobre o assunto, pois a norma dispõe claramente que as leis que menciona tratarão da cooperação entre "a União e os Estados, o Distrito Federal e os Municípios”, ou seja, entre a União e os demais entes, mas sempre com a participação da União (diferente seria caso se tivesse falado, por exemplo, em cooperação entre "União, Estados, Distrito Federal e Municípios"), de modo que se torna coerente que a lei complementar seja federal.

Dessa forma, o ordenamento jurídico brasileiro já acena desde 1988 - se não antes - para a possibilidade jurídica de integração local e regional com vistas à execução conjunta de competências materiais, sendo certo que a própria estrutura federativa já dava suporte a experiências menos formais nessa trilha.

No entanto, seria difícil prescindir de expressa previsão constitucional autorizando a cooperação quando o exercício coordenado das competências extravasasse das atribuições normais de cada ente, envolvendo, por exemplo, a transferência de competências, a criação de uma pessoa jurídica de direito público com caráter interfederativo ou outros desdobramentos pouco ortodoxos da gestão associada de competências comuns. E esse é o caso dos consórcios públicos, na modelagem que a eles se pretendeu conferir.

É no art. 241 que se encontra a única menção expressa aos consórcios públicos na Constituição Federal. Esse artigo, com a redação dada pela Emenda Constitucional n. ${ }^{\circ}$ 19, de 04 de junho de 1998, ${ }^{169}$ estabelece o seguinte:

${ }^{169}$ A antiga redação tratava da extensão, aos delegados de polícia, da isonomia de vencimentos prevista na redação então vigente do art. $39, \S 1^{\circ}$ - e que fora modificada pela mesma EC 19/98 -, em nada se relacionando com o assunto em tela. 
Art. 241. A União, os Estados, o Distrito Federal e os Municípios disciplinarão por meio de lei os consórcios públicos e os convênios de cooperação entre os entes federados, autorizando a gestão associada de serviços públicos, bem como a transferência total ou parcial de encargos, serviços, pessoal e bens essenciais à continuidade dos serviços transferidos.

Conquanto a doutrina ainda esteja iniciando suas incursões no árido terreno da hermenêutica constitucional dos consórcios públicos, e não obstante ainda se revista de controvérsias e ambigüidades o significado da expressão "transferência total ou parcial de serviços", para os fins do art. 241 da Constituição Federal (com a redação dada pela Emenda Constitucional n. ${ }^{o}$ 19/98), ${ }^{170}$ não se há de negar que as linhas mestras do instituto já foram traçadas.

A Emenda n. ${ }^{\circ}$ 19/98, ao tratar dos consórcios e dos convênios de cooperação, procurou iniciar uma organização na maneira como os serviços públicos podem ser prestados em comunhão de esforços entre dois ou mais entes federados, o que até então ficava a cargo da engenhosidade de cada administrador. Já se viu que as necessidades práticas levaram milhares de Municípios a formarem associações, consórcios e convênios de todos os tipos. Além disso, sabe-se que uma das formas mais utilizadas de transferência de serviços a um ente público é a concessão de serviço público, instrumento inicialmente concebido para o transpasse de serviços públicos a particulares. Com a Emenda n. ${ }^{\circ}$ 19/98, ficou claro que a colaboração entre as pessoas políticas deve se dar por meio de consórcios públicos ou convênios de cooperação. Tanto é assim que seria possível indagar se o contrato de concessão de serviços celebrado entre entes públicos continuaria sendo uma alternativa lícita para tal operação. ${ }^{171}$ De todo modo, o debate sobre a questão depende de

${ }^{170}$ Cf. parecer de Benedicto Porto Neto a respeito do projeto de lei que daria origem à Lei de Consórcios Públicos, disponível em:

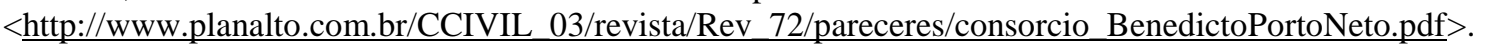

171 PORTO NETO, Benedicto. Parecer sobre a proposta legislativa de criação de consórcios públicos. Disponível <http://www.planalto.com.br/CCIVIL_03/revista/Rev_72/pareceres/consorcio_BenedictoPortoNeto.pdf $>$. Acesso em: 14 nov. 2005. 
um exame mais aprofundado sobre o conteúdo dos consórcios públicos e dos contratos de programa, sendo de toda conveniência reservá-lo, assim, para o tópico próprio. ${ }^{172}$

Com o advento da referida Emenda Constitucional, o governo federal começou a discutir a lei que viria a regulamentar o art. 241 da Constituição, emprestando maior segurança jurídica e administrativa às parcerias entre os entes consorciados. Surgiu assim um grupo de trabalho organizado pela Secretaria de Coordenação Política e Assuntos Institucionais, com a participação de representantes dos ministérios da Casa Civil, Integração Nacional, Cidades, Saúde e Fazenda. Foram incorporadas contribuições dos projetos de lei que tramitavam no Congresso Nacional e de experiências utilizadas em outros países. ${ }^{173}$

O projeto de lei ordinária para regulamentação do art. 241 da Constituição foi encaminhado ao Congresso Nacional em 30 de junho de 2004. Durante a discussão no parlamento, o governo aceitou unir sua proposta ao Projeto de Lei n. ${ }^{\circ} 1.071$, de 1999, do deputado Rafael Guerra, que já estava no Senado. Em março de 2005, foi aprovado pelas Casas Legislativas o projeto consolidado da Lei de Consórcios Públicos, a qual seria sancionada em 06 de abril do mesmo ano.

Verifica-se, portanto, que a Lei $n .^{\circ} 11.107 / 05$, embora tenha origens na Reforma Administrativa de 1998, especialmente por conta da alteração do texto do art. 241 da Constituição Federal, é lei ordinária federal que estabelece normas gerais (ou seja, informadoras de todas as esferas de governo) sobre consórcios públicos, e, sendo assim, não poderia, em tese, encontrar fundamento de validade formal nesse art. 241 , segundo o qual “a União, os Estados, o Distrito Federal e os Municípios disciplinarão por meio de lei os consórcios públicos e os convênios de cooperação entre os entes federados [...]”.

Se o dispositivo refere-se a lei de cada ente, a interpretação que com ele se coaduna não seria, numa primeira leitura, a de que a União pode estabelecer normas gerais sobre consórcios, mas a de que cada um dos entes políticos deve disciplinar por lei a sua própria participação no consórcio. Vale dizer, haveria aí uma exigência de autorização legislativa

\footnotetext{
${ }^{172}$ Cf. item 8.7.2 infra.

${ }^{173}$ Conforme informações disponíveis em: 〈http://www.planalto.gov.br/sri/consorcios/duvidas.htm>. Acesso em: 09 jan. 2008.
} 
(geral ou específica) para a formação de consórcios públicos - e também para a celebração de convênios de cooperação, consoante previsto expressamente.

Para Pedro Durão, da referida norma contida no art. 241 não se extrai a possibilidade de se estabelecer uma ordem geral de regência dos consórcios. ${ }^{174}$ Marcelo Harger também defende que o art. 241 remete à necessidade de lei específica de cada ente federado autorizando a celebração do consórcio público. ${ }^{175}$

Por outro lado, o art. 23, parágrafo único, da Constituição Federal não pode servir como fundamento formal da Lei n. ${ }^{\circ} 11.107 / 05$. Isso porque o dispositivo, embora atribua à União competência para editar normas sobre cooperação entre os entes federados, também exige que isso seja feito por lei complementar, e não ordinária. Além disso, não faz menção à gestão associada de serviços públicos por meio de pessoas jurídicas interfederativas, mas a um vago "equilíbrio do desenvolvimento e do bem-estar em âmbito nacional".

Para Edmir Netto de Araújo, o parágrafo único do art. 23 refere-se a normas para cooperação em nível nacional. ${ }^{176}$ Nesse sentido, não seria possível instituir um consórcio para atuar nacionalmente, com o objetivo de promover "o equilíbrio do desenvolvimento e do bem-estar em âmbito nacional", sem que se editasse a aludida lei complementar. ${ }^{177} \mathrm{~A}$ rigor, interpretando-se o dispositivo em coerência com a cabeça do artigo, que enumera as competências materiais comuns dos entes federados, a conclusão é a de que a lei complementar em questão teria a função de delimitar a participação de cada ente no exercício de tais competências. ${ }^{178}$

Sendo assim, qual o fundamento constitucional da Lei n. ${ }^{\circ} 11.107 / 05$ ?

O legislador procurou deixar claro que a Lei de Consórcios Públicos se alicerçava no art. 22, XXVII, da Constituição Federal, que dispõe competir à União legislar privativamente sobre

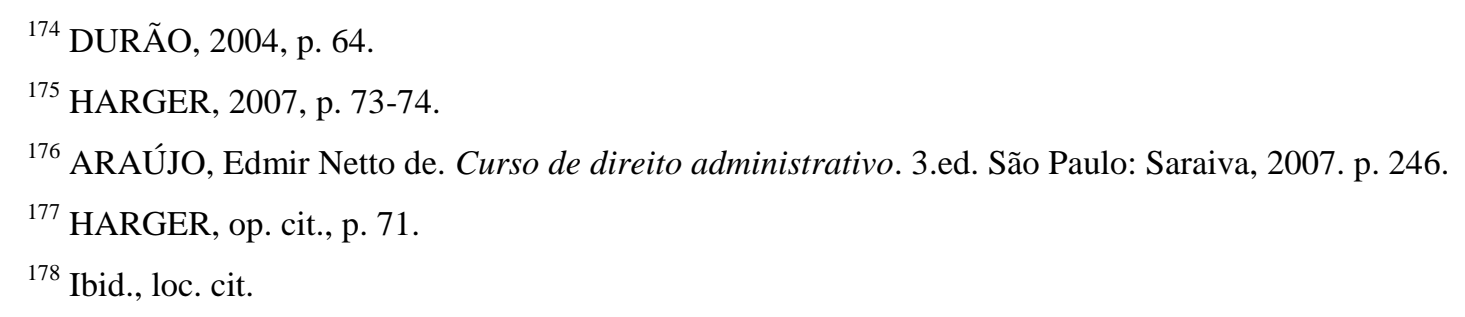


normas gerais de licitação e contratação, em todas as modalidades, para as administrações públicas diretas, autárquicas e fundacionais da União, Estados, Distrito Federal e Municípios, obedecido o disposto no art. 37, XXI, e para as empresas públicas e sociedades de economia mista, nos termos do art. $173, \S 1 .^{\circ}$, III.

A previsão de competência da União para legislar sobre contratação bem poderia constar do art. 24 da Constituição, uma vez que não se trata exatamente de competência privativa, mas sim concorrente. Com efeito, o inciso XXVII do art. 22 deixa expresso que a União só pode editar normas gerais a respeito do tema, cabendo, por conseqüência lógica, aos Estados, Distrito Federal e Municípios minudenciar a matéria por meio de normas específicas no âmbito de suas competências. ${ }^{179}$

Tanto no preâmbulo da Lei n. ${ }^{\circ} 11.107 / 05$ quanto em seu art. $1 .^{\circ}$ encontra-se a referência a "normas gerais" para a contratação de consórcios públicos entre os entes federados. Este seria o objeto da lei.

No entanto, a relação entre o conteúdo da Lei de Consórcios e a competência atribuída à União pelo art. 22, XXVII, da Constituição não é assim tão clara. Enquanto este dispositivo fala em "contratação", aquela lei trata sobretudo da criação de uma pessoa jurídica interfederativa, por meio de um acordo de vontades - cuja natureza contratual será analisada mais adiante. ${ }^{180}$ Maria Sylvia Zanella Di Pietro chega a advertir que

a lei não trata de contratação de consórcios pela União, Estados, Distrito Federal e Municípios, mas de constituição de pessoa jurídica, o que se dá por meio de todo um procedimento, que abrange várias fases (...). $\mathrm{O}$ contrato corresponde a uma das fases do procedimento de construção da entidade. ${ }^{181}$

\footnotetext{
${ }^{179}$ CARVALHO FILHO, José dos Santos. Consórcios públicos. Rio de Janeiro: Lumen Juris, 2009. p. 13-14.

${ }^{180} \mathrm{Cf}$. item 6.1.2 infra.

${ }^{181}$ DI PIETRO, Maria Sylvia Zanella. O consórcio público na Lei $\mathrm{N}^{\circ}$ 11.107, de 6.4.05. Boletim de Direito Administrativo, São Paulo, v. 21, n. 11, p. 1221, nov. 2005a.
} 
Para Diogo de Figueiredo Moreira Neto, o acordo, que define como sendo o ato administrativo complexo que conjuga interesses comuns, buscando um mesmo resultado, atendendo indiretamente ao interesse público (instrumental) e criando deveres de cooperação, não se encaixa na esfera contratual a que se refere o art. 22, XXVII, da Constituição, pois este dispositivo seria uma exceção centralizadora à autonomia das unidades da Federação, devendo ser interpretado restritivamente. ${ }^{182}$

Dessa forma, ao tratar de temas alheios ao da contratação, a União teria extrapolado sua competência, o que macularia a Lei $n .^{\circ} 11.107 / 05$, ou ao menos alguns de seus dispositivos, por vício de inconstitucionalidade formal.

Diversos autores, todavia, contestam esse entendimento. Floriano Azevedo Marques Neto, ${ }^{183}$ Marçal Justen Filho ${ }^{184}$ e Benedicto Porto Neto, ${ }^{185}$ juristas que foram chamados a apresentar um parecer sobre a então proposta de lei sobre consórcios públicos, entenderam que a competência estatuída no art. 22, XXVII, da Constituição Federal possibilita à União editar lei ordinária contendo normas gerais sobre consórcios públicos.

Marçal Justen Filho ressalta ainda que tal competência decorreria também da regra de que todos os temas de interesse de mais de um ente federado devem ser disciplinados por lei nacional, uma vez que, tratando o consórcio da "conjugação de competências, atuação e interesses de entes federados, diversos", verifica-se uma "dimensão de supralocalidade do interesse envolvido", fazendo-se necessária, portanto, a existência de um regramento de cunho nacional. ${ }^{186}$

Dalmo de Abreu Dallari, que também emitiu parecer sobre o projeto de lei, sustentou igualmente a constitucionalidade da lei ordinária federal para disciplinar os

\footnotetext{
${ }^{182}$ MOREIRA NETO, 2001b, p. 46.

${ }^{183}$ MARQUES NETO, Floriano Peixoto de Azevedo. Os consórcios públicos. Revista Eletrônica de Direito do Estado, Salvador: Instituto de Direito Público da Bahia, n. 3, jul./set. 2005a. Disponível em: <http://www.direitodoestado.com.br $>$. Acesso em: 14 nov. 2005.

184 JUSTEN FILHO, Marçal. Parecer elaborado sobre a proposta legislativa de criação de consórcios públicos. Revista Eletrônica de Direito do Estado, Salvador: Instituto de Direito Público da Bahia, n. 3, jul./set. 2005c. Disponível em: 〈http://www.direitodoestado.com.br〉. Acesso em: 14 nov. 2005.

${ }^{185}$ PORTO NETO, 2005.

${ }^{186}$ JUSTEN FILHO, 2005c.
} 
consórcios públicos em todas as esferas, embora não se tenha referido expressamente ao art. 22 da Constituição. ${ }^{187}$

Para Marcelo Harger, a Lei n. ${ }^{\circ}$ 11.107/05 fundamenta-se, de fato, no art. 22, XXVII, da Constituição Federal, dado o caráter contratual dos consórcios. ${ }^{188}$

Com efeito, parece possível a invocação do art. 22, XXVII, da Lei Maior, para legitimar a edição das normas gerais que dizem respeito à formação do acordo de vontades entre os entes federados (por exemplo, o protocolo de intenções, a ratificação por lei de cada ente, o objeto da avença, as hipóteses de dispensa de licitação, o contrato de programa, o contrato de rateio).

Talvez fosse precipitado dizer o mesmo quanto às normas sobre a organização e funcionamento da pessoa jurídica resultante do acordo, eis que o referido dispositivo constitucional fala tão-somente em "normas gerais de licitação e contratação". Dizer que a Lei de Consórcios Públicos trata apenas de regras de contratação equivaleria a dizer, por exemplo, que a Lei n. ${ }^{\circ}$ 6.404/76 (Lei das Sociedades Anônimas) regula unicamente o acordo de vontades formador da sociedade. Ora, ambas as leis dispõem não só sobre a constituição da pessoa jurídica, mas também, e principalmente, sobre sua forma de atuação, seu regime jurídico, sua composição interna, seus poderes, suas limitações, as responsabilidades de seus sócios ou partícipes e outros assuntos atinentes à sua organização como pessoa jurídica.

Por outro lado, afirmar que a União não tem competência para editar normas gerais sobre a pessoa jurídica interfederativa gerada pelo acordo de vontades significaria impedir a criação de tais normas, frustrando, por impraticável, a concretização do art. 241 da Constituição Federal. Ou, pior, significaria deixar a cada ente, com supedâneo nesse artigo, a possibilidade de legislar a respeito, o que instalaria a acefalia e, conseqüentemente, a total incerteza jurídica em nosso federalismo cooperativo, na medida em que concorreriam, para a estruturação de uma mesma pessoa jurídica, diferentes regras, possivelmente conflitantes, emanadas de cada um de seus partícipes.

\footnotetext{
${ }^{187}$ DALLARI, 2005.

${ }^{188}$ HARGER, 2007, p. 72.
} 
Assim é que se mostra razoável a percepção de que os assuntos que afetam mais de um ente da Federação precisam receber tratamento uniforme, sob pena de ameaça ao próprio equilíbrio federativo.

Deve-se enfatizar, nesse sentido, endossando as palavras de Nina Beatriz Stocco Ranieri, que "para o federalismo cooperativo a coordenação das ações é tão essencial quanto a uniformização de certos interesses”, o que significa que

toda matéria que extravase o peculiar interesse de uma unidade periférica porque é comum a todas ou porque, se particularizada num âmbito autônomo, engendraria conflitos ou dificuldades no intercâmbio nacional, constitui matéria principiológica. ${ }^{189}$

Com efeito, sendo imprescindível a coordenação de ações no âmbito da cooperação, inevitável que, para se possibilitar tal coordenação, surja um instrumental jurídico vinculante para todos os envolvidos, enunciador de diretrizes gerais, sem o qual não se concebe a integração de atuações, colocando-se em risco a própria cooperação.

Nesse sentido, somente a União pode editar normas gerais sobre as pessoas jurídicas consorciais.

Sob outro raciocínio, que nos parece reforçar e complementar o aqui exposto, Floriano Azevedo Marques Neto conclui que, exigindo o art. 241 da Constituição a edição de lei por todos os entes federados, encontra-se aí a instituição de uma competência legislativa concorrente, a qual, como se sabe, demanda da União o estabelecimento de normas gerais para regulamentar o tema tratado - no caso, os consórcios públicos e convênios de cooperação. ${ }^{190}$

${ }^{189}$ RANIERI, Nina Beatriz Stocco. Federalismo cooperativo e garantia de padrão de qualidade de ensino: o caso dos estabelecimentos de educação infantil jurisdicionados ao sistema escolar do Estado de São Paulo. Revista da Faculdade de Direito da Universidade de São Paulo, São Paulo, v. 98, p. 363, 2003.

${ }^{190}$ MARQUES NETO, 2005a. 
Dessa forma, justifica-se a competência legislativa da União, mesmo que não se possa subsumir a Lei de Consórcios Públicos ao art. 22, XXVII, da Constituição Federal, por cuidar de temas que não se esgotam na categoria contratual.

Em suma, a Lei de Consórcios Públicos encontra fundamento de validade tanto no art. 22, XXVII, da Constituição Federal - em relação aos dispositivos que efetivamente se referem a matéria contratual - quanto na atribuição, pelo próprio art. 241, de competência legislativa concorrente a todos os envolvidos, bem como no princípio geral de que cabe à União dispor sobre assuntos de interesse de todos os entes federados, o que decorre da própria necessidade de se manter a harmonia federativa.

De todo modo, cumpre anotar que o Congresso Nacional, possivelmente por motivos de ordem prática - haja vista a maior facilidade de aprovar uma lei ordinária -, perdeu excelente oportunidade de regulamentar o art. 23 da Constituição, estabelecendo não só normas sobre consórcios públicos, ${ }^{191}$ mas um estatuto da cooperação no exercício das competências comuns. De mais a mais, é inequívoco que, revestindo a forma de lei complementar, a norma consorcial ficaria convenientemente protegida de maiores críticas quanto à sua constitucionalidade.

Ainda assim, assentada a competência da União para editar normas gerais sobre os consórcios, deve-se ressalvar que isso não significa que a União possa descer a minúcias quanto à normatização dos consórcios públicos - sua atuação deve se restringir à edição de normas gerais, o que, para alguns autores, como Edimur Ferreira de Faria, ${ }^{192}$ não foi o que se deu na Lei n. ${ }^{\circ} 11.107 / 05$.

Entretanto, o conceito de "norma geral" apresenta elevado grau de indeterminação, cabendo à experiência prática, à jurisprudência e à doutrina o árduo trabalho de identificar seus limites nesse caso, a exemplo do que já sucedeu quando dos debates sobre a constitucionalidade da Lei . $^{\circ} 8.666 / 93$, que em muitas passagens cuida de singelos detalhes das licitações e dos contratos administrativos. De qualquer forma, é visível que a

${ }^{191}$ Ainda que o parágrafo único do art. 23 não se refira exatamente à criação de pessoa jurídica integrada por distintos entes da federação, é razoável a assertiva de que o consórcio público não existe senão para promover o "equilíbrio do desenvolvimento e do bem-estar em âmbito nacional" por meio da cooperação entre União, Estados, Distrito Federal e Municípios.

${ }^{192}$ FARIA, Edimur Ferreira de. Curso de direito administrativo positivo. 6. ed. Belo Horizonte: Del Rey, 2007. p. 425. 
Lei . $^{\circ} 11.107 / 05$ se apresenta bem mais comedida que a Lei de Licitações, não dando margem, em princípio, a qualquer afirmação categórica no sentido de que se teria desviado de sua missão de estabelecer apenas as diretrizes gerais dos consórcios públicos no Brasil.

Finalmente, é importante sublinhar que a competência da União para editar normas gerais não retira dos entes estaduais e locais a atribuição de legislarem sobre o mesmo tema, observadas, evidentemente, as diretrizes já estabelecidas pela União. ${ }^{193}$

\subsection{A Lei Federal n. ${ }^{\circ} 11.107 / 2005$}

A Lei n. ${ }^{\circ} 11.107$, de 6 de abril de 2005, pode ser considerada a primeira lei brasileira a tratar especificamente sobre a cooperação federativa. ${ }^{194}$

Pode-se dizer que, na referida lei, os consórcios públicos foram idealizados de molde a, acima de quaisquer outros objetivos, ampliar a abrangência e otimizar a qualidade dos serviços públicos prestados à população.

Ora, como já lecionava, na Argentina, José Roberto Dromi, a idéia subjacente à criação dos consórcios públicos é a de que certas tarefas afetas à competência de diferentes membros da Federação são mais eficientemente cumpridas a partir de um ente comum, centro de imputações coletivas. ${ }^{195}$

Presumivelmente mirando tal escopo, a Lei de Consórcios Públicos veiculou duas inovações fundamentais no sistema de cooperação interfederativa: a concessão de personalidade jurídica aos consórcios públicos e a possibilidade de participação concomitante da União, Estados, Distrito Federal e Municípios em tais arranjos.

Inicialmente, analisada a Lei n. ${ }^{\circ} 11.107 / 05$ sob o ponto de vista das propostas legislativas que lhe deram origem, pode-se dizer que, malgrado se tenha afastado consideravelmente de tais projetos, a lei acabou por confirmar as principais inovações

\footnotetext{
${ }^{193}$ DIAS, 2006, p. 120.

${ }^{194}$ Ibid., p. 133.

${ }^{195}$ DROMI, 1996, p. 491.
} 
neles concebidas, emprestando-lhes, entretanto, uma redação mais concisa. Nesse sentido, observa Cleber Demétrio Oliveira da Silva que a Lei de Consórcios Públicos,

\begin{abstract}
ao dispensar conceituações e detalhamentos demasiados do procedimento consorcial que existiam no projeto de lei, fixou apenas os conceitos indispensáveis ao entendimento do texto legal como, por exemplo, as definições de assembléia geral e contrato de programa. Tal constatação revela que o legislador atuou em conformidade com a doutrina e com a correta técnica legislativa, ao deixar de fora do texto normativo as definições não-essenciais ao regime consorcial, estabelecendo, dessa forma, de fato, regras gerais dos consórcios públicos. ${ }^{196}$
\end{abstract}

Por sua vez, Solange Gonçalves Dias reconhece como maiores contribuições da Lei n. ${ }^{\circ}$ 11.107/05: a possibilidade, nela consagrada, de se constituírem consórcios com personalidade jurídica de direito público, concedendo-se-lhes assim a autoridade necessária para a prática de atividades reservadas ao Poder Público; a conferência de maior estabilidade ao instituto, tendo em vista a previsão de subsistência das obrigações mesmo em caso de retirada de ente ou extinção do consórcio; a atribuição de maior eficácia vinculante ao consórcio, dada a permissão para que os partícipes exijam, uns dos outros, o cumprimento das respectivas obrigações, em particular no que tange aos compromissos financeiros constantes do contrato de rateio. ${ }^{197}$

Trata-se, sem dúvida, de uma ousada reestruturação das relações entre os entes federados, com aspirações capazes de modificar radicalmente a prestação de serviços públicos no Brasil.

Talvez justamente por isso, mal havia sido promulgada, a Lei de Consórcios Públicos já suscitava uma série de questionamentos quanto à sua constitucionalidade. De

196 SILVA, Cleber Demétrio Oliveira da. Lei n. ${ }^{\circ}$ 11.107/05: marco regulatório dos consórcios públicos brasileiros. Jus Navigandi, Teresina, v. 9, n. 705, maio 2005. Disponível em: <http://www1.jus.com.br/doutrina/texto.asp?id=6872 >. Acesso em: 25 nov. 2005.

${ }^{197}$ DIAS, 2006, p. 174. 
fato, além das dúvidas relacionadas à competência da União para estabelecer normas gerais sobre o assunto, ${ }^{198}$ muitas outras surgiram, mirando a inconstitucionalidade material da lei.

Dentre essas dúvidas, encontra-se o delicado tema da delegação de funções entre os entes federados. A Lei . $^{\circ} 11.107 / 05$ deixa expressa a possibilidade de os entes federados delegarem ao consórcio público o exercício de suas competências constitucionais (art. $4 .^{\circ}$, XI, $a$ ). Mas quais seriam os limites dessa delegação? Se a Constituição Federal estabeleceu todo um sistema de repartição de competências materiais, das quais algumas são comuns a todas as pessoas políticas e outras são privativas de cada uma delas, natural que se questione, principalmente, se poderiam tais pessoas transferir o exercício destas últimas a um consórcio integrado por entes que não as detêm.

No atual estágio de desenvolvimento do direito administrativo, não se vê como tal questão possa suscitar maiores embates. Ora, a delegação de funções - especialmente de serviços públicos - é possível e comum no direito brasileiro, e geralmente se opera por meio do instituto da concessão ou permissão, o que não quer dizer, porém, que sejam vedados outros métodos. A única ressalva a ser feita diz respeito às competências ditas nucleares dos entes federativos; nesses casos, a transferência precisaria se respaldar em expressa previsão constitucional. ${ }^{199}$

De outro lado, também suscitou certa polêmica a participação da União nos consórcios, eis que, segundo alguns autores, tal possibilidade introduziria uma medida fortemente centralizadora, contrária ao federalismo. Para Miguel Reale, por exemplo, a intervenção oblíqua (por meio dos consórcios públicos) da União na esfera administrativa dos Estados e Municípios chegaria inclusive a se confrontar "com o disposto, em matéria de intervenção, com os arts. 34 e 35 da Carta Magna". ${ }^{200}$

Nesse sentido, os consórcios com participação da União representariam verdadeiros instrumentos de ingerência central nas questões locais, fora das hipóteses e dos procedimentos previstos nos referidos dispositivos constitucionais.

\footnotetext{
${ }^{198}$ Cf. item 5.1 supra.

${ }^{199}$ MARQUES NETO, 2005a. Cf. também, sobre o tema, o item 8.2.2 infra.

${ }^{200}$ REALE, Miguel. Parecer sobre consórcios públicos. Disponível em: 〈http://www.miguelreale.com.br〉. Acesso em: 22 out. 2005.
} 
A maioria da doutrina, todavia, refuta essa crítica. Embora reconheça a existência de uma "superioridade de fato" da União no federalismo brasileiro, como em muitos outros modelos de federalismo, Dalmo de Abreu Dallari, ao responder exatamente à questão sobre a possível centralização que adviria da promulgação da Lei de Consórcios Públicos - a qual the fora formulada pelos autores do anteprojeto -, afirmou, não sem antes tecer profundas considerações acerca da roupagem atual do federalismo, que "o abuso decorrente da superioridade de poder, se vier a ocorrer, será a expressão de uma situação de fato, contrariando a lei e não autorizada por ela". ${ }^{201}$

Nessa mesma ordem de idéias, Floriano Azevedo Marques Neto entendeu que a previsão de gestão associada de serviços públicos, tal como sistematizada no projeto de lei que lhe fora apresentado, não significava risco de centralização de poderes violadora do princípio federativo constitucional. ${ }^{202}$

Com efeito, é inequívoco que a ascendência da União sobre os demais entes retrata antes uma decorrência do plexo de competências materiais e tributárias a ela atribuídas que uma configuração institucional que favoreça o uso direto ou indireto do mecanismo conhecido por "intervenção federal" - instrumento esse que, diga-se, existe apenas no papel. Ora, já o federalismo norte-americano, desde a década de 30, e durante todo o processo de expansão do intervencionismo econômico, assistiu a um incremento da autoridade da União sobre a dos Estados, até atingir um ponto de tensão, em que a total supremacia daquela restou finalmente preterida em prol de uma cooperação interfederativa, ${ }^{203}$ sendo certo que tais circunstâncias, mesmo em períodos de maior ascendência do poder nacional, jamais chegaram a proporcionar uma ditadura centralizadora.

Em outras palavras, de há muito a União desfruta de competências que lhe colocam, na prática, em situação de precedência sobre os demais entes, precedência essa que não pode, entretanto, traduzir-se em hierarquia jurídica, devendo, por isso mesmo, sofrer constante fiscalização em favor da manutenção do princípio federativo. Nesse diapasão, pretender que a mera possibilidade de associação entre a União e outros entes

\footnotetext{
${ }^{201}$ DALLARI, 2005.

${ }^{202}$ MARQUES NETO, 2005a.

${ }^{203}$ BERCOVICI, 2000, p. 117.
} 
represente uma ameaça ao federalismo é presumir que a União transformará sua vantagem fática em abuso centralizador, o que não parece razoável. Portanto, nada obsta a que a União participe de um consórcio, sendo de todo salutar o controle de sua atuação em vista da autonomia dos entes federados.

Além disso, não se pode olvidar que os Estados e Municípios não são obrigados a integrar um consórcio e, na medida em que optem, no legítimo exercício de sua autonomia, pela adesão, estarão explicitamente aceitando as regras de estruturação e funcionamento sem as quais, como é cediço, não pode funcionar qualquer organização. ${ }^{204}$ Mais que isso, podem também deixar o consórcio a qualquer tempo, devendo apenas honrar as obrigações já assumidas. $^{205}$

Outra dúvida trazida pela Lei de Consórcios dizia respeito à compatibilidade desta com as regiões metropolitanas, aglomerações urbanas, microrregiões e regiões de desenvolvimento integrado previstas nos artigos $25, \S 3^{\circ}$, e 43 da Constituição Federal. Isso porque a Lei Maior já teria disciplinado exaustivamente o modo de integração dos entes federados, de forma que os Municípios, ao participarem de um consórcio público, estariam se esquivando dos mandamentos constitucionais.

O que se pode dizer a respeito é que não há nada na Constituição Federal de 1988 que permita deduzir que a disciplina das modalidades de integração regional seja exaustiva, impedindo o advento de novos institutos - sobretudo se tal advento se dá por emenda constitucional. Todos os mecanismos de integração gozam de igual beneplácito constitucional, servindo cada qual a um intuito distinto, e diferenciando-se todas as modalidades anteriores dos consórcios pela circunstância principal de serem regiões administrativas desprovidas de personalidade jurídica e instituídas por um único ente federado (a União ou o Estado).

De fato, dadas as bases do federalismo de cooperação brasileiro, nada impede que uma emenda constitucional preveja, como fez a Emenda n. ${ }^{\circ}$ 19/98, uma nova forma pela qual se dê tal cooperação. As regiões metropolitanas, aglomerações urbanas, microrregiões e regiões de desenvolvimento integrado coexistem com os consórcios públicos e convênios

\footnotetext{
${ }^{204}$ DALLARI, 2005.

${ }^{205}$ Cf. item 9.1 infra.
} 
de cooperação previstos no art. 241 da Lei Maior, e desse artigo a Lei n. ${ }^{\circ}$ 11.107/05 não é senão um desdobramento necessário.

Dalmo de Abreu Dallari se manifesta pela constitucionalidade da lei também nesse aspecto, esclarecendo que as regiões metropolitanas, aglomerações urbanas e microrregiões representam um incentivo

à conjugação de esforços e de meios para o enfoque amplo, multimunicipal, de questões relacionadas com as funções públicas de todos e de cada um, estando aí compreendidas a racionalização administrativa, a rotina burocrática e qualquer atividade que implique o desempenho de funções públicas e permita ou recomende a conjugação de esforços.

$\mathrm{O}$ autor argumenta ainda que a participação em tais regiões se restringe aos Municípios limítrofes situados no território de um mesmo Estado, o que consubstancia mais um motivo pelo qual se podem diferenciar os consórcios públicos. Estes são integrados pelos mais diversos entes da Federação, e voltam-se à prestação de serviços públicos, podendo ser objeto, inclusive, de transferência dos aludidos serviços, para execução por si ou por outrem, não se limitando, assim, à atuação no campo do planejamento. Desse modo, nada obsta a que um Município faça parte, simultaneamente, de um consórcio público e de uma região metropolitana. ${ }^{206}$

A Lei n. ${ }^{\circ} 11.107 / 05$, diferentemente do que dispunha o Projeto de Lei n. ${ }^{\circ} 3.884 / 04$, não previu a necessidade de os consórcios criados até a sua promulgação se adaptarem a seus preceitos. Ao contrário, a norma consorcial não se aplica aos "convênios de cooperação, contratos de programa para gestão associada de serviços públicos ou instrumentos congêneres que tenham sido celebrados anteriormente a sua vigência" (art. 19).

Diante disso, seria conveniente reservarmos - como já vem fazendo parte da doutrina - a expressão "consórcio público" para designar as entidades constituídas sob a

${ }^{206}$ DALLARI, 2005. 
disciplina da Lei n. ${ }^{\circ} 11.107 / 05$, tratando por “consórcio administrativo" o ajuste celebrado anteriormente a tal diploma legal, que ainda não tenha sido adaptado ao novo regime. ${ }^{207}$

Não são apenas os consórcios administrativos já constituídos que escapam à nova disciplina legal; o art. 19 da Lei n. ${ }^{\circ} 11.107 / 05$ buscou abranger todo tipo de ajuste que tivesse por objeto a gestão associada de serviços públicos, inclusive convênios de cooperação e contratos de programa. Estes últimos, embora tenham sido assim denominados de modo inédito pela própria Lei n. ${ }^{\circ} 11.107 / 05$, de certa forma encontram correspondência, ao menos em alguns de seus traços básicos, com os acordos comumente celebrados entre entes federados e entidades da administração indireta, aos quais Marçal Justen Filho se refere como "concessões-convênios". 208 Por meio desses acordos, freqüentemente Municípios transferem a uma entidade estadual a prestação de um determinado serviço de sua competência, o que se deve, no mais das vezes, à especialização da entidade executora. É bastante usual, por exemplo, que Municípios paulistas firmem ajustes desse tipo com a Companhia de Saneamento Básico de São Paulo - SABESP.

Destarte, todos os acordos anteriores à vigência da Lei n. ${ }^{\circ} 11.107 / 05$ que, de qualquer forma, envolvam gestão conjunta de serviços por diferentes entes públicos, ficam à margem da referida lei, a não ser que se decida por sua adaptação.

A contrario sensu, o disposto na Lei de Consórcios Públicos aplica-se a todo ajuste desse tipo que seja celebrado a partir de 07 de abril de 2005, o que leva à questão, a ser explorada mais adiante, ${ }^{209}$ de saber se, diante da nova regulação do tema, ainda é possível promover a gestão associada de serviços públicos sem a instituição de consórcio público ou a celebração de contrato de programa, que são os instrumentos previstos na Lei n. ${ }^{\circ}$ $11.107 / 05$ para tal fim.

Seja como for, o que parece desde já inquestionável é que a aplicação da lei aos ajustes a ela posteriores não impede a associação precária entre as diversas entidades públicas, na forma de convênios ou mesmo consórcios administrativos despersonalizados,

\footnotetext{
${ }^{207}$ DIAS, 2006, p. 110.

208 JUSTEN FILHO, Marçal. Teoria geral das concessões de serviço público. São Paulo: Dialética, 2003. p. 125.

${ }^{209}$ Cf. item 8.9.2 infra.
} 
sendo certo que a natureza jurídica tradicionalmente atribuída a estes últimos é praticamente idêntica à dos convênios. Dessa forma, fica facultada aos entes federados a opção pela integração rígida do consórcio público ou pelo ajuste tênue dos convênios e consórcios administrativos. $^{210}$

\subsection{O Decreto Federal n. ${ }^{\circ} 6.017 / 2007$}

A lei previu que o Poder Executivo da União deveria ocupar-se de sua regulamentação, disciplinando, inclusive, "as normas gerais de contabilidade pública que serão observadas pelos consórcios públicos para que sua gestão financeira e orçamentária se realize na conformidade dos pressupostos da responsabilidade fiscal" (art. 20). Em outras palavras, o Governo Federal se encarregaria de editar decreto que, regulamentando em minúcias o instituto do consórcio público, seria hábil a consolidar definitivamente o regime jurídico dos consórcios brasileiros.

Mas a regulamentação dos consórcios públicos por meio de decreto federal seria possível, diante de nosso ordenamento jurídico? O problema consiste em saber se norma regulamentar expedida pelo Chefe do Poder Executivo da União poderia ter o condão de vincular os outros entes federados.

A resposta, nesse caso, parece ser afirmativa, ao menos em princípio, por dois motivos. Primeiro, porque, como visto, a edição da lei se inseria na competência da União, de modo que seria natural que sua regulamentação se desse por ato do Executivo federal, no esteio do que dispõe o art. 84, IV, da Constituição da República. Em segundo lugar, porque a própria lei previa, no citado art. 20, a necessidade de sua regulamentação, a ser empreendida pelo "Poder Executivo da União".

No entanto, uma ressalva deve ser feita. Em se tratando da regulamentação de um diploma legal veiculador de "normas gerais", o ato administrativo não pode usufruir de competência que a própria lei não detinha. Desse modo, esvazia-se quase que completamente o sentido do decreto: se, por um lado, um regulamento se justifica para

${ }^{210}$ DIAS, 2006, p. 107. 
detalhar as normas legais, por outro tem-se que o regramento pormenorizado dos consórcios não era concedido à União, muito menos por meio de ato de seu Poder Executivo. A única maneira plausível de se conceber a regulamentação da Lei de Consórcios é entendê-la sob a premissa de que se dê tão-somente para possibilitar a execução dos preceitos legais, que doutra forma restariam ineficazes ou teriam sua implementação prejudicada.

No entanto, a leitura do Decreto n. ${ }^{\circ}$ 6.017, de 17 de janeiro de 2007, editado em obediência ao art. 20 da Lei de Consórcios, permite constatar, em algumas passagens, a inserção de regras que refletem escolhas minuciosas do Executivo federal, não podendo vincular os Estados, Distrito Federal e Municípios. Assim ocorre, por exemplo, com a norma do art. 14, que estabelece a obrigação de o ente consorciado notificar o consórcio sempre que tiver restrições na realização de despesas, empenhos ou movimentação financeira, motivada por normas de direito financeiro, devendo ainda informar ao consórcio "as medidas que tomou para regularizar a situação, de modo a garantir a contribuição prevista no contrato de rateio". Trata-se, à evidência, de norma que não se compatibiliza com o caráter de generalidade que deveria informar a competência da União na espécie.

Além do Decreto n. ${ }^{\circ}$ 6.017/2007, destacam-se outros atos normativos infralegais a conferir apoio para a atuação dos agentes públicos envolvidos com a implementação de políticas públicas em gestão associada. Nesse sentido, pode-se citar o Decreto Federal n. ${ }^{\circ}$ 6.170/2007, que estabelece normas para a transferência de recursos da União mediante convênios, contratos de repasse ou termos de cooperação. No art. $2^{\circ}$, parágrafo único, inciso I, o decreto estimula o consorciamento entre "órgãos e entidades da administração pública direta e indireta [sic] dos Estados, Distrito Federal e Municípios", ${ }^{211}$ na medida em que admite essa integração para que seja alcançado o valor mínimo (R \$ 100.000,00, de acordo com o art. $2^{\circ}$, I) a partir do qual é permitido à União celebrar convênio ou contrato de repasse. Ou seja, caso três Municípios, isoladamente, não possam formalizar um convênio com a União, por envolver o repasse de valor inferior ao mínimo previsto no Decreto, a eles é facultado o consorciamento com vistas a firmar um ajuste de maior valor.

${ }^{211} \mathrm{Na}$ verdade, vimos que não é possível o consórcio público envolver entidades que não sejam pessoas políticas. 
Desnecessário ressalvar, todavia, que o consórcio pressupõe coincidência de objetivos, consistentes necessariamente na gestão associada de determinados serviços públicos.

Finalmente, caberia lembrar a Portaria da Secretaria do Tesouro Nacional n. ${ }^{\circ} 860$, de 12 de dezembro de 2005, que prevê algumas normas financeiras aplicáveis aos consórcios públicos. 


\title{
6. CONFIGURAÇÃO ATUAL DOS CONSÓRCIOS PÚBLICOS
}

\section{$\underline{\text { 6.1. Noção de consórcio público na Lei n. }{ }^{\circ} 11.107 / 2005}$}

A partir dos elementos fornecidos pela Lei n. ${ }^{\circ} 11.107 / 05$, pode-se arriscar uma definição dos consórcios públicos como associações interfederativas encarregadas da gestão associada de serviços públicos, dotadas de personalidade jurídica e criadas por lei de cada um dos entes consorciados.

Alternativamente, pode-se mencionar a conceituação oferecida por Marcelo Harger, para quem os consórcios públicos são

\begin{abstract}
pessoas jurídicas com personalidade de Direito Público ou Privado, formadas exclusivamente por entes federativos, criadas por lei ou por intermédio de autorização legislativa dos entes federados, que desejam associar-se, para, sem objetivar lucro, atender a serviços públicos de interesse comum dos consorciados. ${ }^{212}$
\end{abstract}

Mais importante que definir, no entanto, é identificar os traços característicos do instituto, não sem antes proceder a uma breve consideração sobre os diversos sentidos em que se tem usado o temo "consórcio público".

\subsubsection{Diferentes acepções da expressão "consórcio público”}

A expressão "consórcio público" tem sido usada, no Brasil, com distintos significados. Ora se fala do consórcio no sentido do acordo celebrado, ora se utiliza a mesma expressão para referir o ente criado em decorrência de tal acordo. Encontra-se

\footnotetext{
${ }^{212}$ HARGER, 2007, p. 82.
} 
ainda na literatura jurídica referência ao consórcio público no sentido do que aqui já denominamos "consórcio administrativo". 213

Para fins de possibilitar uma compreensão mais precisa do tema tratado, cumpre estabelecer uma convenção terminológica. Doravante mencionar-se-á "consórcio público" apenas para significar a entidade personalizada formada pela agregação dos entes federados com vistas à gestão associada de serviços públicos, preferindo-se o termo "contrato de consórcio público" ou "ato constitutivo do consórcio público" para referência ao ato por meio do qual se cria e rege o consórcio, e "consórcio administrativo" para indicar aqueles ajustes anteriores à Lei n. ${ }^{\circ} 11.107 / 05$, desprovidos de personalidade jurídica.

A opção terminológica se justifica porque os consórcios públicos, no tratamento da novel legislação, são pessoas jurídicas, constituídas por um ajuste realizado entre entes federados, com vistas à gestão associada de serviços públicos. A tradicional noção de consórcios administrativos como mero acordo de vontades resta superada e, portanto, reservada apenas aos consórcios firmados anteriormente ao advento da nova disciplina, e que a esta não se tenham adaptado. ${ }^{214}$

\subsubsection{Natureza jurídica do ato de constituição dos consórcios públicos}

Os arts. $1^{\circ}, 3^{\circ}$ e $5^{\circ}$, entre outros, da Lei de Consórcios Públicos referem-se ao ato de constituição da entidade como um contrato. É certo que se afigurava útil ao legislador firmar a idéia de que tais ajustes teriam natureza contratual, sobretudo para justificar a competência da União para editar normas gerais sobre consórcios públicos com base no art. 22, XXVII da Constituição. Por outro lado, não menos certo é que a lei não tem o condão de mudar a realidade das coisas; embora possa o legislador submeter determinada situação de fato a um regramento jurídico que, a princípio, não lhe seria aplicável

\footnotetext{
${ }^{213}$ Cf. Capítulo 4 supra.

${ }^{214}$ Em sua obra Direito Administrativo, Maria Sylvia Zanella Di Pietro deixou de tratar do assunto no capítulo referente aos contratos administrativos para abordá-lo no tópico concernente às pessoas da Administração Indireta. Cf. DI PIETRO, Maria Sylvia Zanella. Direito administrativo. 20. ed., São Paulo: Atlas, 2006. p. 318-319.
} 
(mediante o estabelecimento de uma ficção jurídica, por exemplo), descabe a ele determinar a natureza jurídica de determinado instituto, inserindo em uma categoria jurídica objeto que, devido a suas características, a ela não possa pertencer. Não se deve fiar meramente, portanto, na letra da lei para definir a natureza jurídica do ajuste firmado entre entes da Federação com vistas à formação de um consórcio público.

De outra parte, deve-se ter em mente que todo esforço de classificação é simples academicismo, do ponto de vista da ciência do Direito, quando não levar a um resultado prático que permita submeter cada objeto de estudo a um regime jurídico diferente. Já se disse e repetiu à exaustão que as classificações jurídicas não são certas ou erradas, e sim mais ou menos úteis, justificando-se apenas na medida de seu proveito para o aplicador do direito.

Nesse diapasão, verifica-se não ser juridicamente indiferente considerar o ato de constituição de um consórcio público como contrato, convênio, ato complexo, ato coletivo ou mesmo algum acordo de vontades de natureza não contratual. Com efeito, não só está em pauta a competência da União para editar normas gerais sobre "contratação" (art. 22, XXVII, da Constituição Federal), como também a própria aplicação subsidiária do regime jurídico dos contratos administrativos previsto na Lei n. ${ }^{\circ} 8.666 / 93$ e outras, ou do art. 116 da referida lei, ou mesmo do regime aplicável aos atos administrativos, previsto na Lei $n .^{\circ}$ 9.784/99, tudo a justificar a análise sobre a natureza do instituto.

Parte dos doutrinadores, entre os quais Edmir Netto de Araújo, ${ }^{215}$ Diogo de Figueiredo Moreira Neto ${ }^{216}$ e Pedro Durão, ${ }^{217}$ entendiam os consórcios, diante do anterior ordenamento jurídico, como atos administrativos complexos em sentido amplo, tal como concebidos por Vicente Ráo, ${ }^{218}$ adotando, nesse ponto, o conceito estruturado na doutrina ítalo-alemã do ato complexo. Isso porque as várias manifestações de vontade de diferentes pessoas jurídicas, embora tornem o ato bilateral ou multilateral, são paralelas. No caso, a complexidade do ato não é interna a uma pessoa jurídica (o que produziria uma vontade unitária, portanto um ato unilateral), mas externa.

\footnotetext{
${ }^{215}$ ARAÚJO, Edmir Netto de. Do negócio jurídico administrativo. São Paulo: Ltr, 1999. p. 109, 145.

${ }^{216}$ MOREIRA NETO, 1998, p. 46.

${ }^{217}$ DURÃO, 2004, p. 88.
} 
Tito Prates da Fonseca define ato complexo como o ato administrativo para cuja concretização deve haver a manifestação, concomitante ou sucessiva, de mais de um órgão do Estado, singular ou coletivo. ${ }^{219}$

A noção de ato complexo é originária da doutrina alemã, que, no início do século $\mathrm{XX}$, concluía que a figura do contrato era insuficiente para descrever hipóteses nas quais, embora houvesse concurso de manifestações, não tinha lugar o surgimento de obrigações recíprocas para as partes. Foi o alemão Otto Gierke, na obra "Die Genossnchaftstheorie und die Deutsche Rechtsprechung" (A teoria cooperativa e a jurisprudência alemã, Berlim, 1887, p. 133 e ss.), quem primeiro assinalou a categoria jurídica do ato complexo. $^{220}$

O ato complexo, para José Cretella Júnior, não abrange a categoria dos consórcios ou dos acordos, ${ }^{221}$ tampouco se confundindo com o "ato coletivo", que é aquele "que se concretiza pela manifestação da maioria dos membros componentes de um órgão da Administração, constituído por vários titulares". ${ }^{222}$ Nem sempre foi essa a concepção exata de ato coletivo. Georg Jellinek, em "System der subjectiven offentlichen Rechte" (Sistema dos direitos públicos subjetivos, 1892, pp. 193/194), já descrevia o ato coletivo (Vereibarung) como a reunião de atos de vontade produzindo uma única declaração de vontade, fosse de pessoas autônomas, fosse de órgãos de uma coletividade, sempre em vista de um fim comum, em contraposição ao contrato, que busca satisfazer interesses opostos ou não concordantes. ${ }^{223}$ Em certo sentido, o ato formador do consórcio se assemelha mais a essa concepção inicial de ato coletivo que ao conceito atual transcrito acima.

De modo geral, a doutrina brasileira vinha entendendo o ato constitutivo do consórcio administrativo como um acordo de vontades, mas de natureza não-contratual, que seguiria a disciplina jurídica reservada aos convênios. Nesse sentido, Maria Sylvia

\footnotetext{
${ }^{218}$ RÁO, Vicente. Ato jurídico. São Paulo: Saraiva, 1979, p. 56, apud ARAÚJO, op. cit., p. 109.

${ }^{219}$ FONSECA, Tito Prates. Direito administrativo. 1939, p. 371, apud CRETELLA JÚNIOR, José. Dos atos administrativos especiais. 2. ed. Rio de Janeiro: Forense, 1998. p. 147.

${ }^{220}$ CRETELLA JÚNIOR, 1998, p. 140-141.

${ }^{221}$ Ibid., p. 149.

${ }^{222}$ Ibid., p. 139.

${ }^{223}$ Ibid., p. 142.
} 
Zanella Di Pietro, ${ }^{224}$ Hely Lopes Meirelles ${ }^{225}$ e Diógenes Gasparini, ${ }^{226}$ dentre muitos outros, sublinhavam a quase identidade dos consórcios com os convênios, com a peculiaridade de que aqueles eram celebrados entre pessoas da mesma esfera política (entre Estados ou entre Municípios), e estes envolviam todas as espécies de entes federados, ou até mesmo órgãos públicos, entidades da administração indireta e particulares. Não haveria, assim, distinção substancial entre convênios e consórcios, e tanto uns quanto outros não se confundiriam com os contratos.

Neste passo, alcançamos uma das questões mais intrincadas e debatidas do direito administrativo brasileiro: qual seria, exatamente, a diferença entre convênios e contratos?

Os autores até aqui citados - aos quais se poderia somar Leon Frejda Szklarowsky, ${ }^{227}$ e, em seu favor, a jurisprudência do Supremo Tribunal Federal (RTJ 141/619) -, são uníssonos em afirmar que os convênios não apresentam natureza jurídica contratual. Para essa corrente majoritária, os convênios têm por característica principal o fato de aliarem interesses comuns, em busca de um resultado comum, enquanto os contratos envolvem interesses contrapostos, com vistas a resultados diferentes.

Contudo, tal ponto de vista não é pacífico. Celso Antônio Bandeira de Mello ${ }^{228}$ entende que convênios e consórcios são contratos tais como os de sociedade. Edmir Netto de Araújo vê o consórcio como contrato de escopo, de comunhão de objetivos, em oposição aos contratos sinalagmáticos. ${ }^{229}$ Odete Medauar $^{230}$ e Marcelo Harger ${ }^{231}$ também $^{2}$ questionam a diferenciação entre convênios/consórcios e contratos. Este último autor denuncia, por exemplo, que os contratos também podem ter interesses comuns e voltados a

${ }^{224}$ DI PIETRO, 2006, p. 442.

${ }^{225}$ MEIRELLES, Hely Lopes. Direito administrativo brasileiro. 28. ed. São Paulo: Malheiros Editores, 2003. p. 388.

${ }^{226}$ GASPARINI, Diógenes. Direito administrativo. 11. ed. São Paulo: Saraiva, 2006. p. 733.

227 SZKLAROWSKY, Leon Frejda. Os convênios administrativos, convênio, consórcio administrativo, Constituição Federal, Dec-lei 2.300/86 e legislação permanente. Revista dos Tribunais, São Paulo, v. 80, n. 669, p. 39, jul. 1991.

${ }^{228}$ MELLO, Celso Antônio Bandeira de. Curso de direito administrativo. 21. ed. São Paulo: Malheiros Editores, 2006. p. 635.

${ }^{229}$ ARAÚJO, 2007, p. 246.

${ }^{230}$ MEDAUAR, Odete. Direito administrativo moderno. 5. ed. São Paulo: Revista dos Tribunais, 2001. p. 273.

${ }^{231}$ HARGER, 2007, p. 68-69. 
um mesmo objetivo, sendo que, por outro lado, os convênios e consórcios também geram obrigações recíprocas. ${ }^{232}$ Já Marta Luiza Reimão de Deo entende que, encontrando-se os convênios e os consórcios relacionados à prestação de serviços públicos, seriam contratos tais como os de concessão, "visto que sua utilização, antes de mais nada, é sugerida para a execução de serviços e decisões administrativas". ${ }^{233}$

Mesmo autores que defendem a clássica distinção entre os institutos, como Hely Lopes Meirelles, ao mesmo tempo que apontam nos convênios a característica da ausência de vinculação contratual, revelam certa dificuldade em afastar totalmente a idéia de que tais ajustes também envolvem obrigações, afirmando que o partícipe pode se retirar, "só ficando responsável pelas obrigações e auferindo as vantagens do tempo em que participou voluntariamente do acordo". ${ }^{234}$ Ora, a menos que tais obrigações sejam entendidas como aquelas assumidas não pela celebração do convênio em si, mas junto a terceiros na execução do objeto da avença, seria lícito extrair do ensinamento do autor que também o convênio gera obrigações.

Na Espanha, José María Rodríguez de Santiago, que advoga o caráter contratual dos convênios realizados entre as administrações públicas, rebate dois argumentos comumente assinalados pela doutrina mais ortodoxa para negar tal caráter: o de que não se pode admitir a vinculação contratual do exercício de competências públicas e o de que não existem meios processuais para exigir judicialmente o cumprimento das obrigações assumidas. No primeiro caso, utilizando-se do exemplo do convênio de competências instituto do direito espanhol pelo qual os órgãos públicos locais transferem competências reciprocamente, destacando-se mais ainda a polêmica em tela -, o autor pondera que, "si las partes que celebran un convenio podrían, con plena libertad e independencia, elegir cualquier forma (conforme a Derecho) de ejercicio de las competencias de las que son titulares", não se pode impedir que se comprometam, por convênio, a exercê-las de uma forma determinada. Isso não significaria renúncia às próprias competências, mas uma maneira de exercício das mesmas. De outro lado, quanto à ausência de meios processuais

\footnotetext{
${ }^{232}$ HARGER, 2007, p. 68-69.

${ }^{233}$ DEO, Marta Luiza Reimão de. Contratos, convênios e consórcios na prática da administração pública brasileira: paralelo. EDP: Estudos de Direito Público, São Paulo, v. 5, n. 9, p. 82, jul./dez.1986.

${ }^{234}$ MEIRELLES, Hely Lopes. Direito municipal brasileiro. 14. ed. São Paulo: Malheiros, 2006. p. $422-423$.
} 
para cobrar as obrigações, assevera que não se pode classificar as categorias do direito substantivo a partir do direito adjetivo, sendo certo que a previsão de vias processuais de execução forçada das obrigações não determina a natureza do ajuste, mas apenas torna o contrato mais eficaz. ${ }^{235}$

Pode-se concluir das críticas dirigidas à tradicional distinção entre contratos e convênios, tida por insuficiente para abrigar as novas práticas utilizadas pela Administração Pública, ${ }^{236}$ que, a rigor, os convênios apresentam as mesmas notas básicas de todo contrato, gerando obrigações para as partes, e apenas se sujeitando a regime jurídico próprio por desconhecerem a contraposição de interesses, não produzindo benefícios econômicos para nenhum dos partícipes. ${ }^{237} \mathrm{Na}$ verdade, a informação-chave para se considerar um convênio como vinculante seria a intenção das partes de se vincularem juridicamente. ${ }^{238}$

Floriano Azevedo Marques Neto aponta outros fatores que serviriam para afastar a tradicional acepção restritiva dos contratos. Para o autor, um contrato não precisa necessariamente ser bilateral, pois na concessão de serviço público, reconhecida pacificamente como o contrato administrativo por excelência, verifica-se uma relação jurídica "trilateral", envolvendo concedente, concessionário e usuário do serviço público. ${ }^{239}$ Por outro lado, seria possível enxergar no contrato de concessão também uma comunhão de escopo "entre as duas partes explicitamente contratantes", que concorrem para viabilizar a oferta de um serviço público a terceiros. ${ }^{240}$ Também as parcerias públicoprivadas seriam exemplo disso.

Com a máxima vênia à posição do eminente professor da Universidade de São Paulo, e sem embargo das considerações a serem adiante expendidas sobre a procedência da tese que identifica parcialmente os convênios com os contratos, não nos parece que o contrato de concessão seja em tudo similar a um convênio. Ambos são acordos de vontade,

\footnotetext{
${ }^{235}$ RODRÍGUEZ de SANTIAGO, 1997, p. 343-344.

${ }^{236}$ DIAS, 2006, p. 117; MARQUES NETO, 2005a.

${ }^{237}$ JUSTEN FILHO, Marçal. Curso de direito administrativo. São Paulo: Saraiva, 2005b. p. 293. No mesmo sentido, HARGER, 2007, p. 77.

${ }^{238}$ RODRÍGUEZ de SANTIAGO, op. cit., p. 347.

${ }^{239}$ MARQUES NETO, 2005a.

${ }^{240}$ Ibid.
} 
capazes de produzir obrigações recíprocas - disso não se tem dúvida. Mas o contrato de concessão tem sempre caráter bilateral, celebrado entre concedente e concessionário, pois é somente a estes que se atribuem direitos e obrigações, figurando os usuários do serviço como terceiros quanto à relação jurídica de concessão. Estes serão partes de cada um dos contratos que vierem a celebrar, por vontade própria, com o concessionário, e não do contrato de concessão. De outra parte, não se vislumbra na concessão maior comunhão de escopo do que aquela que poderia se entrever num típico contrato de compra e venda, no qual uma das partes almeja o preço e a outra quer a coisa objeto da negociação. No contrato de concessão de serviço público, o concedente pretende, pelos mais diversos motivos, transferir a execução de um serviço público a outrem, geralmente um particular. Este, por sua vez, está diretamente interessado na contraprestação pecuniária que perceberá pela exploração do serviço, e apenas mediatamente - se estiver - no acesso dos usuários ao serviço proporcionado. A comunhão de interesses na concessão é, assim, tão incidental quanto o benefício gerado à economia pelos contratos de compra e venda.

Diogo de Figueiredo Moreira Neto, utilizando-se de terminologia diversa da maioria da doutrina, diferencia o acordo (em sentido estrito, supõe-se) do contrato, sendo que aquele conjuga interesses comuns, buscando um mesmo resultado, atendendo indiretamente o interesse público (instrumental) e criando deveres de cooperação, enquanto este reúne interesses contrapostos, buscando mais de um resultado, atendendo diretamente ao interesse público (finalístico) e criando obrigações recíprocas. Assim, o acordo seria um ato administrativo complexo, não se confundindo nem com contratos, nem com outros tipos de ato administrativo. ${ }^{241}$

Deve-se reconhecer que a solução para o problema enunciado, consistente em perquirir se, em essência, contratos e convênios (ou acordos em sentido estrito) têm a mesma natureza, depende, na verdade, da amplitude do conceito de contrato que se adote. Para que se possa debater a questão, faz-se imprescindível estabelecer essa premissa, sem a qual a discussão corre o risco de perder o caráter científico.

A milenar tradição do direito civil, profundamente arraigada em nossa cultura jurídica, evoluiu a uma concepção contemporânea do contrato como acordo de vontades

${ }^{241}$ MOREIRA NETO, 2001b, p. 46. 
que também pode reunir interesses convergentes, conjugando-os. A rigor, o contrato é uma "composição consensual de interesses" cujo ponto de coincidência atrai as partes pela livre expressão de sua vontade. ${ }^{242}$ Mais do que isso, a idéia de "obrigação", sob o ponto de vista romanístico, é ampla a ponto de alcançar os ônus de cada partícipe de um convênio donde a dificuldade de se negar a existência de obrigações recíprocas também nesse tipo de ajuste, a exemplo do que se dá nos contratos. Mas seria possível, ou mesmo conveniente, aproveitar no direito administrativo os conceitos talhados pela teoria geral do direito?

Para José María Rodríguez de Santiago, o conceito amplo de contrato ora exposto é um "supraconceito", o qual se acomoda em todos os ramos do direito com a mesma estrutura e conteúdo essencial. O autor ressalva, entretanto, que "la aceptación de la figura del contrato en cada una de esas ramas del Derecho impone singularidades de régimen jurídico $[\ldots] " .243$

A Constituição Federal parece ter recepcionado a acepção genérica de contrato consagrada no direito privado, ao menos do que se depreende do inciso XXVII do art. 22, que menciona outras "modalidades" de contratação, sobre as quais pode a União igualmente legislar. ${ }^{244}$ Seria possível entender, portanto, que nosso ordenamento reconhece a categoria contratual como gênero, cujas espécies, naturalmente, apresentam suas peculiaridades.

Sendo assim, a primeira conclusão que se pode obter é a de que convênios e contratos, na condição de acordos de vontade por meio dos quais as partes estipulam obrigações recíprocas, entendidas estas em seu sentido lato, são espécies da categoria contratual. Isso não significa, no entanto, que os institutos sejam idênticos. Ao revés, se convênios e contratos têm tratamento diverso no direito administrativo, então, sob o ponto de vista jurídico, eles ostentam natureza também diversa. Deve-se lembrar, neste passo, que a sistematização científica do direito só pode partir do direito posto, e nunca o contrário. Vale dizer, se os autores administrativistas, em sua maioria, esforçam-se para

\footnotetext{
${ }^{242}$ MELLO, Celso Antônio Bandeira de. Interesse público primário e secundário: convênio entre União e Estado - dever de indenização (parecer). Revista de Direito Público, São Paulo, n. 75, p. 56, jul./set. 1985.

${ }^{243}$ RODRÍGUEZ de SANTIAGO, 1997, p. 341.

${ }^{244}$ DIAS, 2006, p. 118.
} 
diferenciar convênios de contratos, por outra razão não o fazem senão para interpretar a legislação administrativa existente, que de fato reconhece tal distinção.

Com efeito, não se pode ignorar que a Lei $\mathrm{n}^{\circ}$ 8.666/93 concede tratamento inconfundível aos contratos e aos "convênios, acordos, ajustes e outros instrumentos congêneres celebrados por órgãos e entidades da Administração" (art. 116), na medida em que estes se submetem ao regime daquele diploma legal apenas "no que couber". ${ }^{245}$ Ora, se o legislador quisesse igualar todos esses instrumentos, não teria redigido o mencionado art. 116. Mas não só o dispositivo se encontra em vigor, como é inequívoco afirmar que, embora possa haver pontos coincidentes, a disciplina jurídica aplicável aos convênios, no Brasil, não se confunde com aquela incidente sobre os contratos, a começar, por exemplo, pela exigência de licitação, que atinge apenas os últimos. Aliás, quanto a esse específico ponto, anote-se que a constatação, na doutrina e jurisprudência brasileiras - talvez mais que na legislação -, do dogma da inexigibilidade de licitação para a celebração de convênios faz assumir ainda maior importância a tarefa de se demarcar a distinção entre ambos. Afinal, indesejável se torna que, sob a roupagem de convênio, esconda-se um contrato, apenas para frustrar a realização de licitação. De fato, o convênio dissimulado, ao desobrigar da formalização de certame licitatório, "tanto se caracteriza como conduta criminal e ato de improbidade administrativa, como também uma inobservância frontal ao princípio da igualdade entre os licitantes (...)". 246

Além disso, a própria Lei Maior, ao se referir tanto a "convênios" quanto a "consórcios", obriga o intérprete a achar diferença entre ambos, ${ }^{247}$ dado o princípio segundo o qual a lei não contém palavras inúteis. ${ }^{248}$

Sendo assim, pode-se afirmar que, no direito público brasileiro, os convênios não apresentam a mesma natureza dos contratos. Ainda assim, pode-se classificá-los, em coerência à concepção emprestada da teoria geral do direito, como espécie de contrato lato sensu, eis que preenchem os requisitos do direito civil para tanto. Todavia, destoam de

\footnotetext{
${ }^{245}$ DI PIETRO, 2008, p. 229.

${ }^{246}$ DURÃO, 2004, p. 142.

${ }^{247}$ MARQUES NETO, 2005a.

${ }^{248}$ MAXIMILIANO, Carlos. Hermenêutica e aplicação do direito. 14. ed. Rio de Janeiro: Forense, 1994. p. 166.
} 
outras espécies de contrato (como os contratos da Administração), pelos fundamentos a seguir tratados, submetendo-se, por esse motivo, a regime jurídico diverso.

A diferença entre os convênios e os contratos celebrados pela Administração Pública reside essencialmente na existência ou não de paralelismo entre os interesses contemplados no ajuste. A reunião de esforços em prol de um mesmo objetivo caracteriza os convênios; já o acordo visando a metas distintas para cada uma das partes e complementares entre si, resultando numa terceira vontade, que não se confunde com a das partes, caracteriza o contrato. Além disso, pode-se aduzir que, não sendo lícito aos partícipes exigir uns dos outros a satisfação das obrigações assumidas, e não estando eles sujeitos a sanções pelo inadimplemento dos compromissos pactuados, aquelas obrigações e estes compromissos não podem ser considerados obrigações jurídicas, no sentido estrito do termo.

Além desse traço fundamental, Maria Sylvia Zanella Di Pietro aponta outras características dos convênios que justificam seu regime peculiar, alheio ao contratual: ${ }^{249}$

- $\quad$ identidade de objetivos e competências institucionais entre os entes conveniados - o que, diríamos, confirma o paralelismo de interesses;

- $\quad$ busca de um resultado comum, a ser usufruído por todos os partícipes;

- $\quad$ mútua colaboração (financeira, de pessoal etc.), sem existência de preço ou remuneração;

- não-vinculação contratual, inexigindo-se a permanência dos partícipes, e não se aplicando sanções por inadimplência. ${ }^{250}$

A configuração peculiar do convênio em relação ao contrato faz transformar o próprio tratamento conferido aos integrantes da avença, que, a rigor, são tidos por partícipes, e não partes, pois estas pressupõem a existência de objetivos contrapostos. ${ }^{251}$

${ }^{249}$ DI PIETRO, 2008, p. 230.

${ }^{250}$ ARAÚJO, 1999, p. 146. No mesmo sentido, MEIRELLES, 2003, p. 386. Defendendo a possibilidade de aplicação de sanções aos convenentes, sem que isso desnature o instituto, cf. BRITTO, Alzemeri Martins Ribeiro de. Convênios: legítimos meios de fomento e delegação administrativa ou fossos de irregularidades. Advocacia Pública n. ${ }^{\circ}$ 8, p. 8, apud GROTTI, 2003, p. 209.

${ }^{251}$ MEIRELLES, 2003, p. 386. 
Feitas tais considerações, cumpre verificar se o ato de constituição de um consórcio público configura propriamente um contrato da Administração, conforme quis o legislador. Para tanto, necessário é procurar no regramento da Lei n. ${ }^{\circ} 11.107 / 05$ os aspectos tidos como essenciais a esse tipo de contrato, que o diferenciam de um convênio ou ato coletivo em geral.

É inequívoco, de um lado, que o ajuste consorcial denota a comunhão de objetivos dos seus integrantes. Além disso, a lei manteve a possibilidade de livre denúncia do ente da Federação, na forma previamente disciplinada por lei (art. 11).

Mas, por outro lado, faltam requisitos essenciais à classificação do ato de formação de um consórcio público como convênio. $\mathrm{O}$ art. $4^{\circ}{ }^{\circ}$, XII, da lei estabelece que o partícipe adimplente pode exigir dos outros o cumprimento da avença, no que se nota uma firme concretização da exceptio non adimpleti contractus, sendo certo, também, que as obrigações já constituídas, e inclusive os contratos de programa eventualmente celebrados, subsistem até o pagamento das indenizações devidas (art. $11, \S 2 .^{\circ}$ ).

Marçal Justen Filho sustenta que o ato de constituição do consórcio público, na forma da atual legislação, configura um contrato plurilateral, do mesmo tipo dos contratos que constituem sociedades. ${ }^{252} \mathrm{Na}$ mesma linha de raciocínio, Floriano Azevedo Marques Neto pontifica que o instrumento apto à constituição de um consórcio público é necessariamente um contrato, ainda que haja outras formalidades necessárias, como a autorização legislativa. $^{253}$

Para José dos Santos Carvalho Filho, o ato que constitui o consórcio tem a natureza de "acordo plurilateral de cooperação recíproca". ${ }^{254}$

Sem dúvida, o ajuste criador da pessoa jurídica consorcial se caracteriza não só como um contrato em sentido amplo, mas como um contrato da Administração propriamente dito, na medida em que estabelece obrigações jurídicas afetas a cada um dos partícipes. Ora, qualquer ajuste que contenha a previsão de tais obrigações em sentido

\footnotetext{
252 JUSTEN FILHO, 2005c.

${ }^{253}$ MARQUES NETO, 2005a.

${ }^{254}$ CARVALHO FILHO, 2009, p. 26.
} 
estrito não pode ser considerado um convênio, submetendo-se ao regime jurídico contratual.

Tratando-se de contrato, aplicam-se ao ato constitutivo do consórcio, em regra, todas as características inerentes a essa categoria jurídica, como, por exemplo, o princípio da sua "eficácia relativa", ${ }^{255}$ segundo o qual o contrato de consórcio só produz efeitos entre as partes - o que não implica, todavia, que não possam incidir sobre terceiros "efeitos reflexos" decorrentes do acordo. ${ }^{256}$

Por fim, anote-se que, enquanto o ato de constituição do consórcio reveste-se de natureza contratual, o ato de adesão ao consórcio - ou seja, a manifestação de vontade emanada de cada um dos entes federados no mesmo sentido, de contratar o consórcio - é verdadeiro ato administrativo complexo, eis que integrado por manifestações do Executivo (no protocolo de intenções) e do Legislativo (na ratificação).

\subsubsection{Natureza jurídica do consórcio público}

A falta de personalidade jurídica dos consórcios, segundo grande parte da doutrina, em muito impedia a persecução dos seus objetivos, criando sérias dificuldades ao seu funcionamento, de modo que freqüentemente era sugerida a criação de uma pessoa jurídica de direito privado responsável pela administração do consórcio, a qual responderia por seus direitos e obrigações. ${ }^{257}$ Aliás, tal expediente era sugerido também em relação aos convênios, de modo a viabilizar seu melhor funcionamento. ${ }^{258}$

Mas diversos autores repudiavam essa solução, geralmente por considerarem que carecia de previsão legal. ${ }^{259}$

\footnotetext{
${ }^{255}$ RODRÍGUEZ de SANTIAGO, 1997, p. 349.

${ }^{256}$ Ibid,, p. 354, invocando o conceito de Ihering para "efeitos reflexos".

${ }^{257}$ Cf. MEIRELLES, 2003, p. 388.

${ }^{258}$ Id., 2003b, p. 423.

${ }^{259}$ Cf. DI PIETRO, 2006, p. 440; DURÃO, 2004, p. 104; FARIA, 2007, p. 432; GASPARINI, 2006, p. 731.
} 
Fato é que a Lei n. ${ }^{\circ}$ 11.107/05 refletiu a opção por definir que os consórcios públicos teriam personalidade jurídica, como forma de contornar as dificuldades experimentadas até então na concretização da gestão associada.

A permissão legal para criação de uma pessoa jurídica apta a levar a cabo a gestão associada de serviços públicos, conquanto destoe da tradição administrativa brasileira, não pode ser inquinada de inconstitucional - ao revés, coaduna-se com o disposto no art. 241 da Constituição Federal. Para Marçal Justen Filho, a norma constitucional, ao se reportar aos "consórcios públicos e os convênios de cooperação", deixa claro que tais institutos não se confundem. Logo, não poderiam os consórcios ser meras modalidades de convênio. Nesse sentido, impedir a criação de uma pessoa jurídica consorcial seria ignorar a redação do artigo em comento e, com isso, frustrar a vontade constitucional. ${ }^{260}$ Seria possível acrescentar, ainda, que a possibilidade de criação de uma nova entidade dotada de personalidade de direito público, longe de ofender nosso ordenamento jurídico, já se encontrava prevista no próprio art. $41, \mathrm{~V}$, do Código Civil. ${ }^{261}$

Marcelo Harger ressalta que o legislador pode criar outras pessoas jurídicas de direito público, como se depreende "da menção genérica à existência de sociedades controladas direta ou indiretamente pelo Estado que surge em diversos dispositivos constitucionais como, por exemplo, o inciso XVII do art. 37 e o inciso II do art. 71". Além disso, como o art. 241 fala em transferência total ou parcial de encargos, serviços, pessoal e bens, faz-se fundamental que haja um sujeito de direitos destinatário dessa transferência. $^{262}$

Mas a criação de uma pessoa jurídica consorcial, integrada por diferentes entes políticos tem gerado alguma perplexidade na doutrina, acostumada ao conceito de

\footnotetext{
${ }^{260}$ JUSTEN FILHO, 2005c.

261 “Art. 41. São pessoas jurídicas de direito público interno:

$[\ldots]$

$\mathrm{V}$ - as demais entidades de caráter público criadas por lei."

${ }^{262}$ HARGER, 2007, p. 84.
} 
consórcio consagrado na Lei das Sociedades Anônimas, a qual vedava a constituição de uma pessoa jurídica. ${ }^{263}$

Indagou-se, entre outras coisas, se a pessoa jurídica interfederativa representaria o surgimento de um novo ente da Federação, subvertendo a organização federativa estabelecida na Constituição. Miguel Reale vislumbrou essa ameaça, o que, dentre outros motivos, o levou a opinar pela inconstitucionalidade do então projeto de lei de consórcios públicos:

o Projeto examinado cria, a bem ver, uma associação que vem alterar o sentido de nosso federalismo, o qual se distingue pela existência de três entes com competências distintas, cujo relacionamento recíproco a própria Carta Magna disciplina, representando os projetados 'consórcios públicos' um adendo inadmissível ao que a Constituição dispõe. ${ }^{264}$

A maior parte da doutrina, porém, discorda da idéia de que a lei afetaria a organização federativa brasileira, criando um novo ente federado e tolhendo, com isso, a autonomia e as competências dos entes atuais. Com efeito, Dalmo de Abreu Dallari ${ }^{265}$ e Floriano Azevedo Marques Neto ${ }^{266}$ destacam a impossibilidade de se confundir pessoa jurídica de direito público com ente da Federação, ausentes, no consórcio público, as características que permitiriam inseri-lo nesta última categoria. Marçal Justen Filho, por sua vez, lembra que as competências do consórcio são delegadas por ato de vontade dos próprios entes consorciados, não havendo falar em ingerência na autonomia constitucionalmente consagrada. Sob essa perspectiva, "a estrutura federativa do Estado não pode importar a vedação à integração e à associação entre os entes federados". ${ }^{267}$

\footnotetext{
${ }^{263}$ Como é evidente, tais consórcios, firmados entre sociedades empresárias, nada têm a ver com os de que trata a Lei n. ${ }^{\circ} 11.107 / 05$. Mesmo se ambas as leis cuidassem do mesmo instituto, é bem de ver que a mais recente teria derrogado a primeira nesse aspecto, não se podendo apontar qualquer incompatibilidade impeditiva do novo regime consorcial. Cf., a respeito, DALLARI, 2005; JUSTEN FILHO, 2005c.

${ }^{264}$ REALE, 2005.

${ }^{265}$ DALLARI, 2005.

${ }^{266}$ MARQUES NETO, 2005a.

${ }^{267}$ JUSTEN FILHO, 2005c.
} 
De fato, como já foi visto, ${ }^{268}$ é inerente ao federalismo a autonomia das unidadesmembro. Sem autonomia, uma pessoa jurídica não pode ser considerada componente da Federação. Maria Sylvia Zanella Di Pietro observa que uma entidade descentralizada detém capacidade de auto-administração, podendo por isso gerir seus próprios negócios, mas não goza do poder de editar leis, ou seja, de criar direito que se subordina apenas à Constituição (autonomia, em sua acepção política). ${ }^{269}$ Da mesma forma, são os consórcios mecanismos da descentralização administrativa, carentes de autonomia, em todos os seus desdobramentos, sobretudo no que tange à titularidade de competências materiais, legislativas e tributárias próprias, e à prerrogativa de se autogovernar.

Assim, não podem os consórcios ser confundidos com entes federativos, representando apenas uma opção de cada um dos partícipes pela descentralização administrativa da gestão de serviços públicos, como ademais já se fazia, na esfera de cada administração, com a criação de pessoas jurídicas de direito público ou privado.

\subsubsection{A associação pública}

Hoje, a teor do art. $6 .^{\circ}$ da Lei n. ${ }^{\circ} 11.107 / 05$, os consórcios podem assumir a forma de entidades com personalidade jurídica de direito público ou privado.

A lei prevê que o consórcio com personalidade jurídica de direito público integrará a administração indireta de todos os entes consorciados (art. 6.,$\S 1 .^{\circ}$ ). Foi criada, portanto, uma nova espécie de entidade da administração indireta, à qual se deu o nome de associação pública, figura essa incluída, por força do art. 16 da Lei n. ${ }^{\circ} 11.107 / 05$, no rol das pessoas jurídicas de direito público interno constante do art. 41 do Código Civil, entre as autarquias (inciso IV). ${ }^{270}$ Assim, a Lei de Consórcios classificou a associação pública

\footnotetext{
${ }^{268}$ Cf. item 2.1 supra.

${ }^{269}$ DI PIETRO, 2008, p. 43-44.

${ }^{270}$ A modificação do Código Civil era desnecessária; bastava que a própria Lei de Consórcios deixasse clara a natureza autárquica das associações públicas para que estas automaticamente se subsumissem ao gênero "autarquia" previsto no art. 41, IV, do Código Civil, sujeitando-se, por conseguinte, ao respectivo regime jurídico.
} 
como uma espécie do gênero autarquia, de modo que a mesma deverá seguir o regramento aplicável a esse tipo de pessoa jurídica.

O conceito de associação pública introduzido no direito brasileiro não se confunde com o existente no direito português, no qual é aquela definida como "ente público corporacional cujo substrato é constituído por uma colectividade ou conjunto de particulares portadores de determinada posição ou interesse específico comum". ${ }^{271} \mathrm{O}$ sentido estrito de associação pública adotado por Vital Moreira não abrange "as corporações territoriais e os entes corporacionais constituídos pela associação dos próprios entes públicos, entre si ou também com entidades privadas (do tipo dos 'consórcios' e figuras semelhantes)", embora o autor reconheça que, numa acepção mais ampla, corrente em Portugal, ficam incluídos também os consórcios públicos. ${ }^{272}$

O consórcio com personalidade de direito público é expressão clara da descentralização decorrente da coordenação de diferentes entes políticos, ${ }^{273}$ consistindo em manifestação intrinsecamente estatal, dotada de competências, funções, prerrogativas e sujeições próprias dessa qualidade. ${ }^{274}$

O surgimento de um novo tipo de entidade pública não desperta grandes dificuldades ao estudioso quando se tem em mente que o modelo de organização administrativa disciplinado no Decreto-lei n. ${ }^{o}$ 200/67 não é imutável, podendo sofrer alteração por qualquer lei ordinária posterior, nos pontos que não foram incorporados à Constituição. ${ }^{275}$ Sendo assim, nada obsta o surgimento de novas modalidades de pessoa jurídica da administração indireta, e menos ainda quando a inovação se subsume, por expressa previsão legal, a uma categoria jurídica previamente existente: a das autarquias.

Edimur Ferreira de Faria enxerga inconstitucionalidade na previsão legal de criação de pessoa jurídica autárquica por meio de contrato, e não de lei, como exige o art. 37, XIX, da Constituição Federal. ${ }^{276}$ No entanto, em que pese a autoridade do argumento, temos que

\footnotetext{
${ }^{271}$ MOREIRA, Vital. Administração autónoma e associações públicas. Coimbra: Coimbra Ed., 1997. p. 382.

${ }^{272}$ MOREIRA, 1997, p. 383 e 393.

${ }^{273}$ JUSTEN FILHO, 2005b, p. 122.

${ }^{274}$ JUSTEN FILHO, 2005c.

275 Ibid.

${ }^{276}$ FARIA, 2007, p. 431. O citado dispositivo constitucional assim estabelece:
} 
a necessidade de autorização legislativa para proceder-se à contratação do consórcio contratação essa que, por sua vez, ensejará a criação da autarquia consorcial -, permitiria concluir pelo cumprimento da exigência constitucional de lei para instituição de autarquia. Nesse sentido é a lição de José dos Santos Carvalho Filho. ${ }^{277}$

Para Odete Medauar e Gustavo Justino de Oliveira, não havia necessidade de se prever o consórcio como autarquia. O legislador poderia simplesmente ter criado outra pessoa jurídica de direito público, com base no art. 41, V, do Código Civil. ${ }^{278}$

Parece-nos, entretanto, que o legislador preferiu valer-se da disciplina jurídica já existente sobre as autarquias, evitando com isso adaptar a redação de todas as normas legais que se referem a essas entidades, e afastando também eventual alegação de que a nova espécie não se compatibilizaria com o elenco de pessoas jurídicas mencionado no referido art. 37, XIX, da Constituição Federal. Além disso, as associações públicas pouco diferem, em sua essência, das autarquias, sendo razoável sua classificação em meio a estas, com ressalva apenas ao seu caráter especial.

Controversa foi a previsão, na Lei . $^{\circ} 11.107 / 05$, de que o consórcio constituído com personalidade jurídica de direito público integra a administração indireta de todos os entes consorciados - daí falar-se em uma autarquia interfederativa. Para Odete Medauar e Gustavo Justino de Oliveira, o consórcio não precisaria fazer parte da administração indireta dos integrantes. $^{279}$

No entanto, com a devida vênia à posição expressada pelos ilustres autores, não se nos afigura aceitável que o Poder Público crie e controle uma entidade que não pertença à sua estrutura administrativa, sobretudo quando esta adota personalidade jurídica de direito

“Art. 37. A administração pública direta e indireta de qualquer dos Poderes da União, dos Estados, do Distrito Federal e dos Municípios obedecerá aos princípios de legalidade, impessoalidade, moralidade, publicidade e eficiência e, também, ao seguinte:

$[\ldots]$

XIX - somente por lei específica poderá ser criada autarquia e autorizada a instituição de empresa pública, de sociedade de economia mista e de fundação, cabendo à lei complementar, neste último caso, definir as áreas de sua atuação;

$[\ldots] "$.

${ }^{277}$ CARVALHO FILHO, 2009, p. 30-31.

${ }^{278}$ MEDAUAR; OLIVEIRA, 2006, p. 78.

${ }^{279}$ Ibid., p. 78. 
público - mas também no caso de constituir pessoa jurídica de direito privado. ${ }^{280}$ Nesse aspecto, concordamos com Maria Sylvia Zanella Di Pietro ${ }^{281}$ e Edimur Ferreira de Faria, ${ }^{282}$ para quem os consórcios, mesmo se constituídos sob a forma de associação civil, alocamse sempre na administração indireta dos entes federados.

O Supremo Tribunal Federal, examinando a natureza do Banco Regional de Desenvolvimento do Extremo Sul, já decidiu pela inviabilidade constitucional da instituição de uma autarquia interestadual. ${ }^{283}$ À época, entendeu-se que

a validade da criação de uma autarquia pressupõe que a sua destinação institucional se compreenda toda na função administrativa da entidade matriz. [...] O objetivo de fomento do desenvolvimento de região composta pelos territórios de três Estados Federados ultrapassa o raio da esfera administrativa de qualquer um deles, isoladamente considerado; só uma norma da Constituição Federal poderia emprestar à manifestação conjunta, mediante convênio, de vontades estatais incompetentes um poder que, individualmente, a todos eles falece. [...] As sucessivas Constituições da República - além de não abrirem explicitamente às unidades federadas a criação de entidades públicas de administração interestadual -, têm reservado à União, expressa e privativamente, as atividades de planejamento e promoção do desenvolvimento regional $[\ldots] .{ }^{284}$

Todavia, a norma constitucional reclamada pela jurisprudência parece ter surgido exatamente com a nova redação dada ao art. 241 da Constituição Federal. ${ }^{285}$

\footnotetext{
${ }^{280}$ Cf. item 6.1.3.2 infra.

${ }^{281}$ DI PIETRO, 2006, p. 442.

${ }^{282}$ FARIA, 2007, p. 428.

283 Cf. acórdãos em RE 120.932-1/210, Rel. Min. Sepúlveda Pertence, DJ 30/04/1992; ACO 503/RS, Rel. Min. Moreira Alves, DJ 05/09/2003; ADI 175/PR, Rel. Min. Octavio Gallotti, DJ 08/10/1993.

${ }^{284}$ RE $120.932-1 / 210$.

${ }^{285}$ Cf. item 5.1 supra. Nesse mesmo sentido, HARGER, 2007, p. 87.
} 
Seja como for, não se pode negar que desperta estranheza a circunstância de uma autarquia (associação pública) não se sujeitar ao Poder Executivo do ente federado ao qual pertence, ou se vincular ao Poder Executivo de mais de um ente simultaneamente. Por esse motivo é que autores como Edimur Ferreira de Faria apontam inconstitucionalidade na previsão de que um mesmo consórcio participe da estrutura administrativa de mais de uma pessoa política, já que, em geral, as entidades autárquicas têm seus dirigentes indicados pelo ente federado ao qual pertencem, o que não poderia ocorrer no caso da autarquia interfederativa. ${ }^{286}$ Para Odete Medauar e Gustavo Justino de Oliveira, o "excessivo 'misturar-se' das entidades federativas" representa afronta ao federalismo, lesionando também a autonomia dos entes envolvidos, especialmente no que tange aos aspectos da auto-organização e da auto-administração. ${ }^{287}$

Seria possível contrapor às críticas formuladas que nada impede que uma pessoa jurídica integre a administração indireta de diversos entes federativos, uma vez que a gestão associada encontra expressa previsão no texto constitucional, do qual decorre também, conforme exposto, ${ }^{288}$ a necessidade de criação de pessoa jurídica, que só se pode vincular à administração de todos os entes partícipes. De resto, a autonomia dos entes federados não é afetada, uma vez que estes têm a prerrogativa de livre ingresso e retirada do consórcio. ${ }^{289}$ Marçal Justen Filho recorda, a propósito, ser "usual que os diversos entes federados participem de uma mesma sociedade de economia mista", e nem por isso levantam-se maiores questionamentos. ${ }^{290}$

Outro aspecto que chama a atenção no novo regime jurídico dos consórcios públicos é a possibilidade, em tese, de constituição de uma autarquia de existência temporária. É que o art. 4. ${ }^{\circ}$, I, da Lei de Consórcios determina que o protocolo de intenções deve prever o prazo de duração do consórcio - o qual, por sua vez, pode materializar-se, como vimos, em pessoa jurídica de direito público, consoante o art. 6. ${ }^{\circ}, \mathrm{I}$, da lei. Assim, o

\footnotetext{
${ }^{286}$ FARIA, 2007, p. 431.

${ }^{287}$ MEDAUAR; OLIVEIRA, 2006, p. 77.

${ }^{288}$ Cf. item 6.1.3 supra.

${ }^{289}$ HARGER, 2007, p. 94-95.

${ }^{290}$ JUSTEN FILHO, 2005 c.
} 
consórcio será, em princípio, uma pessoa jurídica com prazo de duração determinado. ${ }^{291}$ Odete Medauar e Gustavo Justino de Oliveira observam não se ter notícia de caso similar no direito brasileiro. ${ }^{292}$

De todo modo, o fato de ser incomum a previsão de uma entidade com data marcada para se extinguir não acarreta a invalidade da exigência. Outrossim, cremos ser cabível sustentar que o preceito legal restaria atendido mesmo com a previsão, constante do protocolo de intenções, de que o consórcio teria prazo de duração indeterminado, até porque nada impediria que se procedesse a sucessivas alterações do contrato, prorrogandose a vigência do consórcio. Tal possibilidade, aliás, consta expressamente do art. $5^{\circ}$, I, do Decreto Federal n. ${ }^{\circ}$ 6.017/07, que regulamenta a Lei de Consórcios Públicos.

Importa anotar, ainda, que o art. 15 da Lei n. ${ }^{\circ}$ 11.107/05 determina que, no que não contrariar aquela lei, a organização e o funcionamento dos consórcios seguem a disciplina legal das associações civis (arts. 53 a 61 do Código Civil). Aqui, mais uma vez, surge uma forte mescla entre os regimes de direito público e de direito privado. No entanto, a previsão de aplicação das normas civis às associações públicas, que são, como visto, espécie do gênero autarquia, traz ao intérprete a dificuldade quase intransponível de identificar, uma a uma, as regras de "organização e funcionamento" que devem ser buscadas nas leis de direito administrativo e aquelas que podem ser emprestadas do direito civil.

Como já dito, o consórcio constituído sob as normas do direito público recebe atribuições e poderes de natureza estatal, o que os levaria a compartilhar, por regra, "do regime de direito público dos entes administrativos que os compõem (inclusive quanto ao regime de pessoal e quanto ao regime financeiro)". 293

Talvez uma solução seria a de se entender que a própria previsão legal de que o consórcio pode revestir a forma de pessoa jurídica de direito público, configurando verdadeira autarquia (art. $6^{\circ}, \mathrm{I}$ ), entra em confronto com o art. 15 da mesma lei, o qual só se aplica "no que não contrariar" a Lei de Consórcios. Logo, por conflitar com o regime jurídico das autarquias, a disciplina civil prevista no art. 15 não poderia ser aplicada às

\footnotetext{
${ }^{291}$ PAULO, Vicente; ALEXANDRINO, Marcelo. Direito administrativo. 12. ed. Rio de Janeiro: Impetus, 2006. p. 48.

${ }^{292}$ MEDAUAR; OLIVEIRA, op. cit., p. 78.

${ }^{293}$ MOREIRA, Vital, 1997, p. 394.
} 
associações públicas. Esta parece ser a solução que melhor se coaduna com o nosso ordenamento jurídico, já que o regime jurídico de direito público, a par de ser expressamente obrigatório para diversas particularidades de um consórcio (como a admissão de pessoal, a fiscalização contábil etc.), é o que sempre se aplicou às autarquias, exatamente por sua compatibilidade com as funções e objetivos de tais entidades. Ainda assim, não se poderia descartar, em caso de lacuna na legislação de regência das autarquias (mas apenas nesse caso), o recurso às normas do Código Civil sobre associações civis, desde que estas não vão de encontro à disciplina legal específica dos consórcios públicos e do regime jurídico-administrativo em geral.

Assim, seria lícito afirmar, por exemplo, que as associações públicas submetem-se à supervisão prevista no art. 19 e seguintes do Decreto-lei n. ${ }^{\circ}$ 200/67, e não ao princípio da

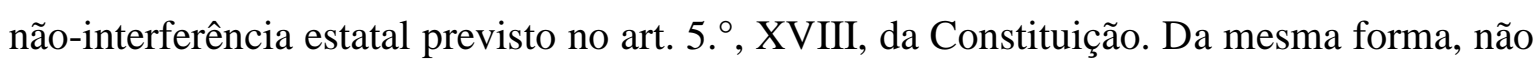
podem invocar a liberdade individual para escapar ao estipulado no art. 28 daquele mesmo diploma legislativo federal. ${ }^{294}$ Enfim, a aplicação das normas dos arts. 53 a 61 do Código Civil deve ser afastada sempre que significar uma fuga do regime publicístico sistematizado para as autarquias.

A conclusão a que chegamos decorre dos princípios do direito público, mais do que da legislação especificamente aplicável aos consórcios públicos brasileiros. Mesmo na Espanha, por exemplo, entende-se aplicável aos convênios interadministrativos, subsidiariamente, a legislação sobre contratos administrativos. ${ }^{295}$ É bem verdade que isso não se pode fazer sem um considerável esforço interpretativo, devendo ser excluídas, por exemplo, as regras de contratação administrativa que pressuponham a existência de uma relação de subordinação entre os sujeitos contratantes. ${ }^{296}$ De todo modo, pode-se afirmar que aos convênios interadministrativos aplicam-se, portanto, suas normas específicas, e,

\footnotetext{
294 “Art. 28. A entidade da Administração Indireta deverá estar habilitada a:

I - prestar contas da sua gestão, pela forma e nos prazos estipulados em cada caso;

II - prestar a qualquer momento, por Intermédio do Ministro de Estado, as informações solicitadas pelo Congresso Nacional;

III - evidenciar os resultados positivos ou negativos de seus trabalhos, ratificando suas causa e justificando as medidas postas em prática ou pela adoção se impuser, no interesse do Serviço Público.”

${ }^{295}$ RODRÍGUEZ de SANTIAGO, 1997, p. 356-357.

${ }^{296}$ Ibid., loc. cit.
} 
em caso de lacuna, as normas de contratação administrativa que não suponham relação de subordinação entre as partes, as normas de direito administrativo e, só então, as normas de direito privado, nessa ordem de preferência. ${ }^{297}$

Embora sejam identificáveis soluções teóricas para a imprecisão legislativa quanto ao regime jurídico aplicável aos consórcios públicos, cumpre reconhecer que, na prática, tal confusão acaba por implicar uma indireta abertura, ao administrador, de uma margem de atuação que representa um verdadeiro leque de justificativas legais para as mais variadas escolhas no tocante às normas a serem seguidas pelo consórcio. Assim, é de se supor que, salvo onde houver clara exigência legal (como, por exemplo, as do art. $6 .^{\circ}, \S$ 2. ${ }^{\circ}$ ), os responsáveis pela gestão do consórcio adotarão, em cada caso, a postura mais conveniente aos seus interesses, esteja ela prevista no direito público ou no privado, valendo-se para tanto da caótica disciplina legal.

Evidentemente, não se está a criticar a existência de discricionariedade - que é natural e salutar - na condução da atividade administrativa, mas a forma como essa margem de liberdade, que não pode ser considerada propriamente discricionariedade, acabou sendo outorgada, nesse caso específico, ao administrador: contra a vontade do legislador. Obviamente, este não quis conceder àquele a possibilidade de optar, a qualquer tempo, entre a aplicação das normas de ordem pública ou privada de gestão do consórcio; ao contrário, procurou oferecer apenas uma escolha inicial quanto à formatação jurídica da entidade (associação pública ou associação civil) e, a partir daí, detalhar - excessivamente, diga-se - a incidência de cada regime. Justamente por isso, gerou uma disciplina tão ambígua que pode levar à produção de uma verdadeira arbitrariedade na execução da lei, não proveniente de um ato de consciente outorga legislativa, mas das dificuldades de interpretação e aplicação das normas pertinentes.

Talvez a ânsia de aplicar as recém-importadas teorias da reforma do Estado tenha levado a uma adoção pouco criteriosa de conceitos públicos e privados, que se misturam ao largo das cautelas necessárias à higidez da técnica jurídica - podendo-se citar como exemplo cabal, além do visitado neste tópico, a sugestão de contratação entre órgãos da

${ }^{297}$ Ibid., p. 359. 
Administração (art. 37, $\S 8^{\circ}$, da Constituição Federal, inserido pela Emenda Constitucional n. $\left.{ }^{\circ} 19 / 98\right)$.

6.1.3.2. O consórcio com personalidade jurídica de direito privado - associação civil

Assim como o consórcio de direito público, o consórcio com personalidade jurídica de direito privado também recebe os poderes necessários à gestão associada de serviços públicos. No entanto, tais poderes limitam-se, como não podia deixar de ser, àqueles mais diretamente ligados à atividade prestacional, à semelhança do que se dá quando da transferência da execução de um serviço público, via concessão, a um particular. Em outras palavras, as prerrogativas inerentes ao poder de Estado, como a regulação do serviço, não podem ser conferidas aos consórcios constituídos sob os moldes do direito privado. ${ }^{298}$

Para Marçal Justen Filho, o repasse das competências ao consórcio pessoa privada depende da celebração de um contrato de programa. ${ }^{299}$ Parece-nos, porém, que, se o instituto consorcial foi criado justamente para que se pudesse, por meio dele, atribuir a um ente personalizado a gestão associada de serviços públicos, inclusive acompanhada da "transferência total ou parcial de encargos, serviços, pessoal e bens essenciais à continuidade dos serviços transferidos" (art. 241 da Constituição Federal), seria redundante a celebração de outro contrato com a mesma finalidade.

Se o consórcio se constituir sob personalidade jurídica de direito privado, ainda assim sofre um grande influxo de normas de ordem pública. ${ }^{300} \mathrm{Com}$ efeito, tais entidades deverão seguir as normas do direito público para licitação, celebração de contratos, prestação de contas e admissão de pessoal, que será regido pela Consolidação das Leis do Trabalho (art. 6. ${ }^{\circ}, \S 2 .^{\circ}$, da Lei de Consórcios Públicos). Além disso, a execução das receitas e despesas do consórcio deve obedecer à legislação financeira aplicável às entidades públicas (art. 9. ${ }^{\circ}$ ). De resto, o regramento a ser seguido nesse caso será o das

\footnotetext{
${ }^{298}$ JUSTEN FILHO, 2005b, p. 132.

${ }^{299}$ Ibid., loc. cit.. Sobre contratos de programa, cf. item 8.9.2 infra.

${ }^{300}$ Como não poderia deixar de ser, eis que o consórcio sempre reúne entes federados.
} 
associações civis (art. 15), não fazendo jus o consórcio, por exemplo, às prerrogativas da Fazenda Pública em juízo.

Para boa parte da doutrina, causa espécie a possibilidade de uma pessoa jurídica formada por entes políticos integrantes da Federação brasileira assumir vestes de direito privado. Floriano Azevedo Marques Neto chegou a asseverar que semelhante previsão seria incompatível com a própria adjetivação constitucional dos consórcios, referidos expressamente como "consórcios públicos", aos quais só se poderia cogitar de imprimir regime publicístico, até porque tais entidades não teriam apenas a incumbência de gerir serviços de natureza econômica, mas de administrar serviços públicos em sentido amplo. ${ }^{301}$

Odete Medauar e Gustavo Justino de Oliveira, embora sem acusar explicitamente a inconstitucionalidade da norma, observam que não se justifica a natureza de pessoa jurídica privada aposta aos consórcios, ${ }^{302} \mathrm{e}$, endossando a opinião de Alice González Borges, ${ }^{303}$ ressaltam a incoerência de se transferir a uma associação civil o desempenho de determinadas competências que não se harmonizam com o regime de direito privado. Cleber Demétrio Oliveira da Silva acompanha as críticas, denunciando a "indesejável dupla sujeição do consórcio público em termos de regime jurídico" sem razão plausível que a justificasse. ${ }^{304}$ No mesmo sentido é a opinião de Lílian Maria Salvador Guimarães Campos. $^{305}$

Marcelo Harger também entende criticável a previsão de consórcio com personalidade jurídica de direito privado, mas conclui que este deve ser aceito, da mesma forma que se admite há tempos a existência de fundações com personalidade de direito privado instituídas pelo Poder Público. ${ }^{306}$

\footnotetext{
${ }^{301}$ MARQUES NETO, 2005a.

${ }^{302}$ MEDAUAR; OLIVEIRA, 2006, p. 76.

303 BORGES, Alice González. Os consórcios públicos na sua legislação reguladora. Revista Eletrônica de Direito do Estado, Salvador: Instituto de Direito Público da Bahia, n. 3, jul./set. 2005. Disponível em: <http://www.direitodoestado.com.br >. Acesso em: 20 nov. 2005.

304 SILVA, Cleber Demétrio Oliveira da. Lei n. ${ }^{\circ}$ 11.107/05: marco regulatório dos consórcios públicos brasileiros. Jus Navigandi, Teresina, v. 9, n. 705, 2005a. Disponível em: <http://www1.jus.com.br/doutrina/texto.aspid=6872>. Acesso em: 25 nov. 2005.

305 CAMPOS, 2006, p. 94.

${ }^{306}$ HARGER, 2007, p. 90.
} 
Numa análise puramente jurídica, há que se concluir pela ausência de impedimento legal ou constitucional à instituição de uma pessoa jurídica de direito privado com atribuição de gerir serviços públicos. No entanto, dadas as peculiaridades do consórcio público, que envolvem o exercício de poderes transferidos de diversos entes federados por parte de uma entidade pertencente à estrutura de todos eles, verifica-se não haver vantagem alguma em se criar um consórcio com personalidade de direito privado. ${ }^{307}$ Ao contrário, o consórcio desse tipo terá maiores dificuldades para realizar seus objetivos institucionais, apresentando-se quiçá como alternativa menos eficiente para a gestão de serviços públicos que a prestação direta pelos entes federados.

$\mathrm{O}$ art. $4 .^{\circ}$, IV, da Lei n. ${ }^{\circ} 11.107 / 05$ dispõe que o consórcio estabelecido sob personalidade de direito privado não pode ter fins econômicos. A expressão deve ser entendida em termos hábeis, uma vez que, em um sentido amplo, as atividades de um consórcio público terão sempre conteúdo econômico, na medida em que envolvem "a alocação de recursos materiais para a satisfação de certas necessidades humanas", 308 consubstanciada na prestação de serviços públicos. Mas não é nesse sentido que devemos interpretar a norma, sob pena de impossibilitar sua aplicação. O legislador só pode ter se referido a "fins econômicos" na acepção utilizada no art. 53 do Código Civil, que coincide com a de "fins lucrativos", 309 ou seja, os consórcios constituídos sob regime de direito privado não podem efetivar a distribuição dos lucros eventualmente obtidos.

José dos Santos Carvalho Filho, ${ }^{310}$ Odete Medauar e Gustavo Justino de Oliveira ${ }^{311}$ concluem que a única modelagem possível para um consórcio que opte pela personalidade de direito privado é a de associação civil. Lílian Maria Salvador Guimarães Campos, após

\footnotetext{
${ }^{307}$ CAMPOS, 2006, p. 96.

${ }^{308}$ HARGER, 2007, p. 45.

${ }^{309}$ Assim dispõe o art. 53 do Código Civil:

“Art. 53. Constituem-se as associações pela união de pessoas que se organizem para fins não econômicos."

Para uma exegese do significado do termo "fins econômicos" nesse dispositivo, concluindo-se pela sua coincidência com "fins lucrativos", cf. BERGER, Renato; TOZZINI, Syllas. A finalidade das associações no novo Código Civil. Jus Navigandi, Teresina, v. 7, n. 66, jun. 2003. Disponível em: <http://jus2.uol.com.br/doutrina/texto.asp?id=4126>. Acesso em: 12 jan. 2008.

${ }^{310}$ CARVALHO FILHO, 2009, p. 34.

${ }^{311}$ MEDAUAR; OLIVEIRA, 2006, p. 75-76.
} 
sugerir que os consórcios também poderiam revestir a forma de fundação, acaba por se juntar aos demais autores, concluindo que o art. 15 da Lei n. ${ }^{\circ}$ 11.107/05 só deixa espaço à opção pela associação civil, em se tratando de consórcio com personalidade jurídica de direito privado. ${ }^{312}$

Realmente, não parece haver outra formatação possível para o consórcio de direito privado, dadas as premissas de que este é uma reunião de pessoas - e não de capital ou patrimônio - sem finalidade lucrativa.

Consoante já exposto, ${ }^{313}$ embora a lei não estabeleça de modo expresso, ou mesmo que se possa interpretar que ela, ao contrário, pretendeu excluir o consórcio com personalidade jurídica de direito privado da administração indireta dos partícipes, deve-se entender pela aplicação da mesma regra válida para as associações públicas, eis que não se concebe uma entidade personificada, instituída pelo Poder Público e por ele controlada, que não componha a estrutura administrativa pública. ${ }^{314}$ Mais difícil ainda seria explicar a existência de leis ratificando a participação de um ente federado numa entidade que não faz parte da Administração Pública, nem dele nem de nenhum outro ente. ${ }^{315}$

Fica claro ainda que, mesmo que não se classificassem os consórcios com personalidade jurídica de direito privado na administração indireta dos entes consorciados, seu regime seria equivalente ao das entidades de direito privado que integram essa administração, ${ }^{316}$ ou seja, a questão sobre sua inclusão ou não "deixa de ter conseqüências práticas de maior relevo". 317

Resolvida a questão da inserção dos consórcios de direito privado dentre as pessoas jurídicas da administração indireta, seria possível indagar se eles teriam natureza autárquica, tal como as associações públicas. Desde logo se pode afirmar que a resposta é negativa, de vez que os consórcios modelados sob a forma de associação civil não apresentam as características básicas que identificam o regime publicístico das autarquias,

\footnotetext{
${ }^{312}$ CAMPOS, 2000, p. 95.

${ }^{313}$ Cf. item 6.1.3.1 supra.

${ }^{314}$ DI PIETRO, 2006, p. 442. No mesmo sentido, CARVALHO FILHO, 2009, p. 40.

${ }^{315}$ PAULO; ALEXANDRINO, 2006, p. 49.

${ }^{316}$ HARGER, 2007, p. 95-97; PAULO; ALEXANDRINO, 2006, p. 49.

${ }^{317}$ HARGER, 2007, loc. cit.
} 
sujeitando-se parcialmente ao regime jurídico de direito privado. ${ }^{318}$ Sendo assim, parecem não se subsumir a nenhuma das figuras que tradicionalmente integram a administração indireta dos entes políticos, consistindo tão-somente em associações civis de natureza especial, pela ligação que têm com o Poder Público.

Por fim, vale ressaltar que a existência jurídica do consórcio, quando se opta por sua instituição na forma de associação civil, depende ainda, depois da ratificação legislativa do protocolo de intenções, da inscrição de seu ato constitutivo no registro civil (art. $6^{\circ}$, II, da Lei n. $\left.{ }^{\circ} 11.107 / 05\right)$.

Em suma, cabe destacar como principais diferenças entre o consórcio de direito privado e o de direito público a possibilidade de este receber atribuições tipicamente estatais, como os poderes de regulação e imposição de sanções; a possibilidade que só este tem de se valer de certas prerrogativas típicas do Poder Público, como os prazos processuais dilatados; o fato de aqueles só poderem contar com pessoal regido pela Consolidação das Leis do Trabalho (CLT), de acordo com o disposto no art. $6^{\circ}, \S 2^{\circ}$, da Lei de Consórcios; e o surgimento da personalidade jurídica em momentos distintos: com a edição das leis que ratifiquem o protocolo de intenções, para este, impondo-se, para aquele, além desse requisito, também o cumprimento das formalidades da legislação civil. ${ }^{319}$

\subsection{Distinção entre a noção atual e a anterior de consórcio}

Para a doutrina clássica, ${ }^{320}$ os consórcios eram praticamente idênticos aos convênios, mas só podiam ser celebrados por entidades de mesma natureza e nível de governo, aceitando entre seus partícipes os entes da administração indireta. ${ }^{321}$ Essa característica costumava ser apontada como traço diferenciador dos consórcios em relação aos convênios. Por trás da peculiaridade, encontrava-se o fato de que, quando se fala em

\footnotetext{
${ }^{318}$ Ibid., p. 76.

${ }^{319}$ HARGER, 2007, p. 92.

${ }^{320}$ MEIRELLES, 2003, p. 388. Cf. também GROTTI, 2003, p. 214; GASPARINI, 2006, p. 732-733; e DI PIETRO, 2005b, p. 300.

${ }^{321}$ DI PIETRO, 2005b, p. 300.
} 
entes de mesma natureza e espécie, refere-se de certa forma à identidade de competências constitucionais. Já nos convênios, a cooperação podia significar a execução de atividades de competência de apenas uma das partes.

Diógenes Gasparini menciona ainda outra diferença entre convênios e consórcios administrativos: estes teriam estrutura administrativa diferente, mais complexa em relação à exigida para os convênios, uma vez que diversas leis tratando de consórcios específicos cuidavam da necessidade de se constituírem órgãos como um conselho consultivo, uma autoridade executora e um conselho fiscal. ${ }^{322}$

Ora, tais exigências estruturais decorriam de uma importante distinção quase sempre encontrável entre convênios e consórcios: a instituição destes usualmente refletia uma opção dos governos envolvidos no sentido de uma colaboração permanente, ou ao menos prolongada, com vistas ao equacionamento de um determinado problema comum a dois ou mais entes federados - geralmente Municípios. Por exemplo, criava-se um consórcio para melhorar o atendimento à saúde da população local. Ao longo de sua vigência, o consórcio implantava gradativamente seu planejamento unificado, por meio da contratação de profissionais da área de saúde, da construção de hospitais e postos de saúde suficientemente equipados para prestar serviços a diversos Municípios circunvizinhos, e de outras providências que se fossem descobrindo necessárias à medida que se geriam os serviços públicos.

Já os convênios seriam mais indicados para resolver questões pontuais, tais como, por exemplo, a reforma de um hospital municipal, caso em que uma entidade repassava recursos, mediante prestação de contas, para que o Município interessado procedesse à reforma. Sendo assim, justificável que as leis existentes exigissem dos consórcios, de regra, que contassem com estrutura apta a levar a efeito a constante persecução das metas mais genéricas - que costumavam ter.

De qualquer forma, deve-se reconhecer que as diferenças apontadas pela doutrina não chegavam a adentrar a essência dos institutos, limitando-se a aspectos acidentais como a composição ou a usual existência de órgãos administrativos. Por esse motivo é que José dos Santos Carvalho Filho entendia, diante do anterior ordenamento jurídico,

${ }^{322}$ GASPARINI, 2006, p. 733. 
“desnecessária e inconveniente fazer a distinção entre os institutos, isso sem contar a circunstância de que não havia norma de direito positivo que lhe desse suporte". ${ }^{323}$

Se antes da Lei n. ${ }^{\circ}$ 11.107/05 os consórcios tinham exatamente a mesma natureza dos convênios, atualmente verifica-se o total distanciamento entre as figuras, tendo o consórcio ganho personalidade jurídica, e seu ato de constituição recebido contornos contratuais. Ademais, os consórcios não se dão mais necessariamente entre entes públicos de mesma espécie e natureza, e não podem mais envolver entidades da administração indireta.

\subsection{O consórcio público e figuras similares no direito comparado}

Inspirados no direito alienígena, notadamente no italiano, os consórcios públicos brasileiros apresentam algumas semelhanças e diversas diferenças em relação a figuras previstas em outros ordenamentos. ${ }^{324}$

Como já procuramos expor, ${ }^{325}$ a colaboração interfederativa é há décadas uma tendência mundial, que só recentemente ganhou, entre nós, os instrumentos que permitem sua elevação a um grau máximo: os consórcios públicos dotados de personalidade jurídica. Como não podia ser diferente, o avançado grau de desenvolvimento da coordenação administrativa em outros países produziu uma complexa gama de ajustes a que se pretende fazer aqui uma breve menção, apenas com o escopo de melhor se entender a lógica inspiradora da cooperação que buscou o legislador brasileiro desde a aprovação da Emenda Constitucional n. ${ }^{\circ} 19 / 98$.

O país em que todas as federações se basearam são os Estados Unidos. Nesse país, no entanto, registram-se críticas dos juristas sobre o estágio de evolução do federalismo cooperativo, que se encontraria ainda incipiente, especialmente quando comparado ao de

\footnotetext{
${ }^{323}$ CARVALHO FILHO, 2009, p. 8.

${ }^{324}$ Cf. MEDAUAR; OLIVEIRA, 2006, p. 101-105.

${ }^{325}$ Cf. item 2.1 supra.
} 
países como a Alemanha. ${ }^{326}$ Quando se contrasta tal avaliação com a notícia de que, já em 1834, dois Estados norte-americanos (Nova Iorque e Nova Jérsei) firmaram possivelmente o primeiro convênio interestadual da história, a respeito de águas comuns, ${ }^{327}$ pode-se deduzir que a caminhada do federalismo norte-americano rumo à mitigação do dogma dualista tem sido bastante lenta.

Talvez a razão disso seja a exigência, contida no n. 3 da Seção 10 da Constituição, de aprovação do Congresso para o aperfeiçoamento dos "tratados" celebrados entre Estados, mesmo com as atenuações que a cláusula tem recebido - como a interpretação jurisprudencial de que o consentimento parlamentar pode ser implícito. ${ }^{328}$

Ainda assim, é possível encontrar nos Estados Unidos vários tipos de acordos intergovernamentais, que vão desde verdadeiros contratos onerosos de prestação de serviços, passando pelos ajustes que têm por objeto precípuo o oferecimento gratuito de um serviço, até a associação para planejamento, financiamento e prestação conjunta de serviços públicos de atribuição comum a duas ou mais jurisdições. Tais acordos podem envolver uma vasta gama de assuntos, como segurança pública, presídios, serviços judiciários e fiscalização de construções, podendo autorizar a utilização conjunta de equipamentos, imóveis e pessoal. ${ }^{329}$

As principais espécies de acordos intergovernamentais nos Estados Unidos são o "understood contract", que se trava entre pequenas comunidades circunvizinhas, em caráter informal e que pode, por isso mesmo, ser preterido em face de obrigações previstas em contratos escritos; o "service contract", método mais comum de contratação, que se assemelha a um contrato de prestação de serviços mediante contraprestação pecuniária; e o “joint agreement”, que é o que mais se aproxima dos consórcios brasileiros, pela previsão de um corpo administrativo encarregado de lidar com o compartilhamento

${ }^{326}$ GRESS, Franz. Interstate cooperation and territorial representation in intermestic politics. Publius: the Journal of Federalism, Easton, v. 26, n. 1, p. 57-58, 1996.

${ }^{327}$ FALCÃO, Alcino Pinto. Aspectos da cooperação horizontal no federalismo. Revista de Direito Público, São Paulo, v. 7, n. 33, p. 27, 1974.

${ }^{328}$ FALCÃO, 1974, p. 28.

329 MUNICIPAL cooperation guide: MRSC Report, n. 27, Sept. 1993. Washington: Cooperation Guide Research and Services Center of Washington, Intergovernmental Agreements, 1993. Disponível em: <http://www.mrsc.org/Subjects/Planning/intrgov.aspx >. Acesso em: 22 out. 2007. 
intergovernamental da execução de uma função específica, ou da construção de uma obra. $^{330}$

De outra banda, destaca-se ainda no direito norte-americano a existência de acordos entre entes federativos que extrapolam o território do país, como a associação para cooperação econômica regional integrada por cinco estados do noroeste americano e duas províncias canadenses, e, no sul, a organização de cooperação ambiental composta por dez Estados fronteiriços, sendo quatro americanos e seis mexicanos. ${ }^{331}$

Na Alemanha, a Constituição prevê os agrupamentos de comunas e os "Landkreis", que seriam os "agrupamentos de Municípios de circunscrição rural". 332 Além disso, os acordos entre os "Länder" (Estados-membros da Federação alemã) são também tão comuns quanto antigos, encontrando origem no elevado grau de autonomia mantido pelos Estados que se reuniram para formar a nação alemã. ${ }^{333}$

Ainda mais próximos dos consórcios brasileiros são os consórcios públicos argentinos, definidos por José Roberto Dromi como "entes públicos no estatales, asociativos, de gestión local o regional, que cumplen actividades de realización y/o prestación de obras y servicios". 334

Trata-se de entidades dotadas de personalidade jurídica, cujo regime recebe maior ou menor influxo de normas de ordem pública conforme os fins que perseguem, as prerrogativas de que gozam e a forma de controle a que se sujeitam. ${ }^{335}$ De todo modo, têm sempre caráter público, definido pelas prerrogativas especiais que recebem do Estado. ${ }^{336}$

A principal diferença entre o consórcio público argentino e o brasileiro está nas possibilidades de composição. Enquanto vimos que, no Brasil, o consórcio só pode envolver entes federados, na Argentina a entidade consorcial pode ser integrada por pessoas jurídicas públicas estatais e não-estatais, além de pessoas jurídicas privadas e até

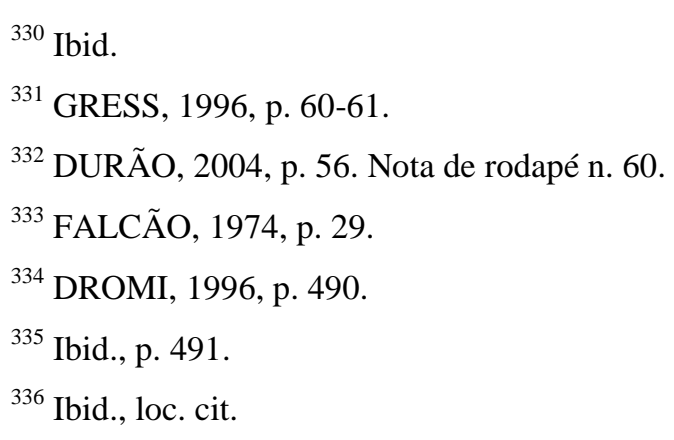


mesmo pessoas físicas (sempre sob regime publicístico, caso contrário estar-se-ia diante de um "consorcio privado"). A forma mais semelhante à brasileira, que reúne entes públicos, é chamada "mancomunidad" - a exemplo das associações de municípios espanhóis. ${ }^{337}$

O consórcio público argentino é criado a partir de uma convenção jurídica plurilateral à qual se aplicam subsidiariamente os princípios da disciplina dos contratos administrativos, e que, de regra, não necessita obter aprovação de lei específica - no caso dos municípios, por exemplo, basta que a associação esteja respaldada por preceitos definidores de competências, contidos nas respectivas leis orgânicas. ${ }^{338}$

Interessante notar como existem Estados que, embora não tenham adotado uma forma federativa - ao menos não nos moldes do federalismo clássico -, são profícuos em normas disciplinando os mais variados mecanismos de coordenação interadministrativa. Tal fato relaciona-se, de certo modo, com a orientação descentralizadora da administração pública no mundo ocidental, responsável por conferir, em maior ou menor grau, autonomia a órgãos e entidades vinculados ao poder central. Uma vez consagrada a autonomia de um ente público, estão lançadas as bases para se discutir a cooperação desse ente para com os demais integrantes dos quadros administrativos, ou seja, o alcance e perfil de sua integração no conjunto de órgãos que compõem o aparato governamental.

Nesse sentido, verifica-se que na Espanha, por exemplo, a Constituição promulgada em 29 de dezembro de 1978 prevê, em seu art. 145:

\section{Artículo 145.}

1. En ningún caso se admitirá la federación de Comunidades Autónomas.

2. Los Estatutos podrán prever los supuestos, requisitos y términos en que las Comunidades Autónomas podrán celebrar convenios entre sí para la gestión y prestación de servicios propios de las mismas, así como el carácter y efectos de la correspondiente comunicación a las Cortes Generales. En los demás supuestos, los acuerdos de cooperación entre las

${ }^{337}$ Ibid., p. 491.

${ }^{338}$ DROMI, 1996, p. 493. 
Comunidades Autónomas necesitarán la autorización de las Cortes Generales. $^{339}$

É justamente na Espanha que se encontra uma das figuras européias mais semelhantes aos nossos consórcios públicos. Trata-se das "mancomunidades", que são associações de municípios das quais se origina uma entidade local personalizada. Essa entidade recebe, por delegação, competências dos municípios, com o objetivo de desempenhar a prestação conjunta de serviços públicos.

A Espanha conta também com corporações formadas pela associação de entes heterogêneos (Estado, Comunidades Autônomas, entes locais etc.), a que se tem denominado genericamente "consorcios", que se tornam verdadeiras "Administraciones Públicas” em sua plenitude. ${ }^{340}$

Naquele país, o princípio de cooperação que rege as relações entre administrações públicas, expressado num "dever geral” de prestação recíproca de informação, assistência técnica e ajuda financeira, entre outras coisas, manifesta-se com ainda maior intensidade e complexidade nos ajustes que a doutrina denomina "convênios de colaboração em sentido estrito", por meio dos quais as partes se obrigam a prestações específicas visando à efetivação do princípio cooperativo. ${ }^{341}$

Dentre tais convênios de cooperação, pode-se distinguir entre os "convênios de cooperação para o exercício de tarefas alheias" e os "convênios para o exercício coordenado pelas partes de suas próprias competências”. Nos primeiros, uma das partes apenas presta auxílio para que outra administração convenente possa exercer suas próprias

${ }^{339}$ Em tradução livre:

Artigo 145.

1. Em nenhum caso se admitirá a federação de Comunidades Autônomas.

2. Os Estatutos poderão prever as hipóteses, requisitos e termos em que as Comunidades Autônomas poderão celebrar convênios entre si para a gestão e prestação de serviços próprios das mesmas, assim como o caráter e efeitos da correspondente comunicação às Cortes Gerais. Nas demais hipóteses, os acordos de cooperação entre as Comunidades Autônomas necessitarão da autorização das Cortes Gerais.

${ }^{340}$ GARCÍA de ENTERRÍA, Eduardo; FERNÁNDEZ, Tomás-Ramón. Curso de derecho administrativo. 8. ed. Madrid: Civitas, 1997. v. 1, p. 388-389.

${ }^{341}$ RODRÍGUEZ de SANTIAGO, 1997, p. 145-147. 
competências. Nos últimos, ambos os partícipes se comprometem a exercer suas competências num determinado sentido, compatibilizando-se. ${ }^{342}$

Tal distinção se assemelha à que se verifica no Brasil entre os convênios, nos quais se estabelece, "uma relação de cooperação em que um ente fornece meios para que o outro exerça suas competências, provendo-o do quanto necessário e transferindo-lhe eventualmente obrigações", e os consórcios administrativos, em que geralmente há uma conjugação de esforços "por meio da qual os entes consorciados, de forma perene, passam a exercer cada qual suas competências através do ente consorcial". 343

Além das modalidades acima mencionadas, conhecem os espanhóis ainda as figuras do "convênio para transferência de serviços administrativos" e do "convênio urbanístico entre administrações públicas". Mas é só por intermédio dos "convênios de competências" - que na verdade possuem caráter normativo, e não contratual - que se admite, naquele país, a transferência ou delegação de competências, excluída esta, portanto, da órbita de atuação dos convênios de colaboração. ${ }^{344}$

De outra banda, muita tradição têm os consórcios administrativos na Itália, talvez o país que maior destaque dê ao assunto. No entanto, lá, o alcance jurídico dos consórcios é significativamente maior do que ostenta entre nós, abrangendo ajustes entre particulares, público-privados, ou entre entes e órgãos estatais.

Historicamente, aliás, o termo "consórcio" tem sido empregado pelos italianos em uma acepção ampla e residual, para indicar uma forma de união que não se confundia com a associação, nem com a sociedade. ${ }^{345}$

Antonio Azara e Ernesto Eula definem os consórcios administrativos italianos como "associazione di persone giuridiche publiche o di proprietari fondiari privati, constituita per provvedere a fini ed interessi di pubblica amministrazione". ${ }^{346}$

\footnotetext{
${ }^{342}$ Ibid., p. 147-148.

${ }^{343}$ MARQUES NETO, 2005a.

${ }^{344}$ RODRÍGUEZ de SANTIAGO, op. cit., p. 149-150, 340.

${ }^{345}$ GIANNINI, Massimo Severo. Diritto amministrativo. 3. ed. Milano: A. Giuffrè, 1993. p. 241.

346 AZARA, Antonio; EULA, Ernesto. Novissimo digesto italiano, v. 4, Roma: Vnione Tipografico - Editrice Torinese, 1978, p. 250, apud DURÃO, 2004, p. 101. Permitimo-nos traduzir o excerto da seguinte forma:
} 
Também a França conta com importantes institutos de coordenação administrativa. Embora não seja Estado federado, como é sabido, a França encontra-se dividida em regiões. Atualmente são 26 regiões, sendo 21 regiões metropolitanas, além da Córsega e de 4 regiões ultramarinas (Guadalupe, Martinica, Guiana Francesa e Reunião). Cada região é dividida em departamentos, havendo hoje em dia 96 departamentos metropolitanos e 4 ultramarinos. Os departamentos constituem tanto uma divisão administrativa como uma coletividade territorial. Eles são divididos, por sua vez, em distritos (arrondissements), e estes em cantões (canton). Finalmente, os cantões são repartidos em municípios (communes).

É entre esses municípios que se estabelece a maior parte das relações que se poderia comparar com as derivadas dos consórcios públicos brasileiros. ${ }^{347}$

As formas de intermunicipalidade (intercommunalité) na França nem sempre dão lugar à criação de estabelecimentos interadministrativos ("établissements publics intercommunaux"), mas é por meio deles que a cooperação é mais bem atingida. Quando envolvem a criação de estabelecimentos públicos de cooperação, os mecanismos de intermunicipalidade se dividem em sindicatos intermunicipais e outros estabelecimentos públicos de cooperação intermunicipal. Os primeiros, que representam uma gradação menos densa e mais ágil de cooperação, não contando com sistema próprio de arrecadação fiscal, subdividem-se em sindicatos de vocação única, de vocação múltipla e sindicatos de aglomerações novas (syndicat d'agglomération nouvelle - SAN). Já a outra categoria de estabelecimentos públicos intermunicipais, que conta com sistema próprio de obtenção de recursos - o que lhes assegura autonomia financeira - e reflete um nível mais coeso de integração, consiste nas coletividades urbanas (communauté urbaine); coletividades de aglomeração (communauté d'agglomération); e coletividades de comunas (communauté de communes).

A coletividade urbana pode ser criada em aglomerações a partir de 50 mil habitantes, podendo ter por objeto tarefas relacionadas ao urbanismo, transporte urbano de

\footnotetext{
“associações de pessoas jurídicas ou de particulares proprietários de terras, constituída para perseguir fins e interesses da Administração Pública".

${ }^{347}$ A breve exposição sobre as formas de coordenação administrativa na França baseia-se em DEVOLVÉ, Pierre; VEDEL, Georges. Droit administratif. 11. ed. Paris: Presses Universitaires de France, 1990. p. 534-546.
} 
passageiros, combate a incêndios, saneamento etc., sendo administrada por um conselho cuja composição varia de acordo com o número de municípios e a sua população.

A coletividade de aglomeração é um estabelecimento público de caráter administrativo que se ocupa principalmente do desenvolvimento econômico e planejamento do espaço comunitário, sendo dirigido por um conselho composto por delegados eleitos pelo sufrágio universal, escolhidos na mesma época e sob os mesmos requisitos das eleições municipais.

As coletividades de comunas são mais recentes, derivadas da conversão dos antigos distritos urbanos, e destinam-se ao planejamento do espaço e ações de desenvolvimento econômico, notadamente no meio rural.

Existem ainda, na França, os estabelecimentos públicos interdepartamentais, com personalidade jurídica civil e autonomia financeira, administrados por um conselho designado pelas assembléias gerais interessadas. Por fim, seria possível destacar a existência de estabelecimentos inter-regionais e de estabelecimentos públicos criados entre coletividades de níveis diferentes, como os sindicatos mistos.

Analisando-se os ricos modelos de cooperação interfederativa e interadministrativa encontrados no direito comparado, é inevitável concluir que os consórcios públicos, ainda recebidos na doutrina pátria com certa perplexidade decorrente de seu "radicalismo" em relação à nossa prática cooperativa, são apenas um primeiro passo rumo à estruturação de um verdadeiro sistema de coordenação administrativa. 


\section{FORMAÇÃO DO CONSÓRCIO PÚBLICO}

\subsection{Considerações preliminares}

A Lei n. ${ }^{\circ} 11.107 / 05$, complementada pelo Decreto Federal n. ${ }^{\circ}$ 6.017/07, disciplinou exaustivamente a construção do consórcio público.

Inicialmente, cabe observar que, em que pese a matiz contratual com que o legislador procurou tingir os consórcios, não há como se exigir licitação para sua constituição, conforme assevera Marçal Justen Filho, ${ }^{348}$ pelo fato de se tratar de uma manifestação de cunho associativo e colaboracional entre pessoas políticas. Para Pedro Durão, a licitação não é dispensável nem inexigível, mas "inaplicável". ${ }^{449}$ Com efeito, mesmo as normas sobre dispensa e inexigibilidade da Lei n. ${ }^{\circ}$ 8.666/93 parecem dirigir-se a situações distintas da de cooperação interadministrativa.

O que se exige, para a formação dos consórcios públicos, é a autorização do Poder Legislativo de cada ente, traduzida na ratificação, por lei, do protocolo de intenções subscrito pelos representantes das pessoas políticas interessadas.

Anote-se que a mudança planejada, mas não aprovada, para o art. 89 da Lei n. ${ }^{\text {o }}$ 8.666/93 introduziria dois tipos penais, relacionados à inobservância das formalidades previstas para subscrição de protocolo de intenções e para a celebração de contrato ou instrumento congênere com o intuito de gestão associada de serviços públicos. Mas o fato de essa alteração ter sido retirada do texto definitivo não significa, obviamente, uma permissão às práticas apontadas, mesmo porque se trata de descumprimento de exigências legais; apenas não podem elas ser, hoje, consideradas crime.

\subsection{Composição}

348 JUSTEN FILHO, Marçal. Comentários à Lei de licitações e contratos administrativos. 11. ed. São Paulo: Dialética, 2005a. p. 270. 
Os consórcios públicos podem ser firmados entre todas as esferas de governo, envolvendo Municípios, Estados, Distrito Federal e União. As entidades da administração indireta não podem fazer parte dos consórcios, mas podem celebrar contratos ou convênios com estes, para cumprimento dos objetivos consorciais, dispensada a licitação (art. $2 .^{\circ}$, III, da Lei n. ${ }^{\circ}$ 11.107/05). Como vimos, a atual configuração do tema em muito se distancia das concepções tradicionais, segundo as quais os consórcios só podiam ser celebrados por entidades de mesma natureza e nível de governo, permitindo-se entre seus partícipes as pessoas da administração indireta. ${ }^{350}$

Hoje em dia, a participação nos consórcios públicos limita-se às pessoas de direito público, mas não a todas elas: somente àquelas dotadas de autonomia política, ou seja, os entes da Federação. ${ }^{351}$

Consoante o art. $1 .^{\circ}, \S 2 .^{\circ}$, da Lei n. ${ }^{\circ} 11.107 / 05$, “a União somente participará de consórcios públicos em que também façam parte todos os Estados em cujos territórios estejam situados os Municípios consorciados". Tudo leva a crer que o legislador se preocupou, aqui, com a eventual interferência excessiva da União nos assuntos dos Municípios, à revelia dos Estados.

Tal temor parece um tanto despropositado: se nosso país fez a opção por um federalismo em três níveis, há que se conceder verdadeira autonomia a todos eles. E não se tem autonomia quando a associação de um ente a outro é condicionada à participação de um terceiro, que não deveria ter qualquer ascendência hierárquica sobre nenhum dos demais, e pode nem apresentar interesse na avença alheia. Severamente criticável, portanto, a opção do legislador. ${ }^{352}$

Curioso notar que, embora o art. $1 .^{\circ}, \S 2 .^{\circ}$, da Lei de Consórcios impeça a formação de um consórcio envolvendo apenas União e Municípios - exigindo a participação dos Estados em cujo território se localizem tais comunas -, e não obstante os incisos III e V do $\S 1 .^{\circ}$ do art. $4 .^{\circ}$, que se referiam à constituição de consórcios envolvendo um ou mais Estados e Municípios, ou um ou mais Estados, Distrito Federal e Municípios, tenham sido

\footnotetext{
${ }^{349}$ DURÃO, 2004, p. 92.

${ }^{350}$ Cf. MEIRELLES, 2003, p. 388, e DI PIETRO, 2005b, p. 300.

${ }^{351}$ CARVALHO FILHO, 2009, p. 20.
} 
vetados - justamente porque não exigiam a participação dos Estados em cujo território se situassem os Municípios consorciados, o que poderia afetar a "paz federativa" -, o art. 4. ${ }^{\text {o, }}$ $\S 1 .^{\circ}$, IV da lei não repete o raciocínio, autorizando o consorciamento entre Distrito Federal e Municípios, sem impor a participação dos Estados onde se situam tais Municípios. Aparentemente inexplicável que se tenha mantido o inciso IV, quando as razões dos vetos aos incisos III e V pareciam servir também a essa hipótese:

(...) por meio de emenda, o Congresso Nacional retirou o requisito que o Município fosse contíguo ao Estado, o que permite - a se manter a redação atual - que um Estado se consorcie com Municípios de outro Estado mesmo que não haja relações de vizinhança que legitime (sic) esse consorciamento. Evidentemente que a manutenção desse dispositivo é perigosa para a paz federativa, uma vez que um Estado poderá interferir nos assuntos municipais de outro Estado sem ter, ao menos, uma relação de vizinhança que legitime a sua ação. $\mathrm{O}$ mesmo raciocínio se aplica à necessidade de veto do inciso $\mathrm{V}$.

A proibição de consórcio envolvendo somente União e Municípios é, todavia, atenuada pela previsão contida no art. 14 da lei, que permite à União celebrar convênio diretamente com um consórcio público, sem excluir a hipótese de que tal consórcio seja composto exclusivamente por Municípios. Referido dispositivo parece, ao menos em princípio, contrastar com a norma do art. $1 .^{\circ}, \S 2 .^{\circ}$, uma vez que, ao contemplar a possibilidade de que a União celebre convênio com consórcios públicos, sem ressalvar os consórcios de Municípios, acaba por fornecer um meio de aquele ente contornar a exigência de que sua participação em um consórcio com municípios se condicione à participação de todos os Estados em cujo território se situam tais comunas. Ora, se no $\S 2$. $^{\circ}$ do art. $1 .^{\circ}$ o legislador preocupou-se com eventual desequilíbrio federativo que poderia advir da associação direta entre União e municípios, qual seria a justificativa para que a mesma preocupação não se fizesse presente no art. 14 ?

${ }^{352}$ Nesse sentido, CARVALHO FILHO, op. cit., p. 21. 
A explicação talvez resida na circunstância de que a união de esforços mediante convênio tem caráter mais precário, ${ }^{353}$ não redundando, por exemplo, na constituição de uma pessoa jurídica, de modo que não representa a mesma ameaça vislumbrada pelo legislador no que tange à celebração de um consórcio público.

Diante do estatuído no art. $1^{\circ}, \S 2^{\circ}$, seria possível questionar se não haveria uma restrição implícita à formação de consórcios entre Municípios e outro Estado sem a participação do Estado onde se situam tais comunas, aplicando-se simetricamente a vedação de que a União contrate consórcios com Municípios sem a participação dos Estados onde se localizam os Municípios em testilha. ${ }^{354}$ Para Odete Medauar e Gustavo Justino de Oliveira, não pode haver consórcio entre Estados e Municípios sediados em outros Estados, ou mesmo entre Municípios de diferentes Estados, por ausência de previsão no art. $4^{\mathrm{o}}, \S 1^{\mathrm{o}}$, do estatuto consorcial. ${ }^{355}$ Vicente Paulo e Marcelo Alexandrino entendem da mesma forma. ${ }^{356}$

Desse entendimento discorda Marcelo Harger, sob o fundamento de que o $\S 1^{\circ}$ do art. $4^{\circ}$ da Lei n. ${ }^{\circ} 11.107 / 05$ não se destina a regular as possibilidades de composição dos consórcios, mas a sua área de atuação. ${ }^{357}$ Com efeito, o dispositivo em questão remete expressamente ao inciso III do art. $4^{\circ}$, que trata da área de atuação do consórcio, e não ao inciso II, que cuida da identificação dos partícipes. Sendo assim, não obstante sirva o aludido parágrafo como importante diretriz para se extraírem as possíveis variações na composição do consórcio, não pode ser considerado como demarcador de rol exaustivo dessas mesmas variações, mas tão-somente das áreas de atuação a serem atribuídas ao consórcio. Não há na lei, portanto, regra delimitadora dos arranjos federativos - exceção feita ao já aludido $\S 2^{\circ}$ do art. $1^{\circ}$, de modo que a interpretação, em princípio, deve prestigiar o máximo leque de possibilidades, autorizadas, genericamente, pelo art. $1^{\text {o }}$, caput, da Lei de Consórcios Públicos, e pela própria estrutura federativa tripartite de nosso Estado.

\footnotetext{
${ }^{353}$ Cf. item 3.3 supra.

${ }^{354}$ HARGER, 2007, p. 97.

${ }^{355}$ MEDAUAR; OLIVEIRA, 2006, p. 27-28.

${ }^{356}$ PAULO; ALEXANDRINO, 2006, p. 45.

${ }^{357}$ HARGER, op. cit., p. 98.
} 
Odete Medauar e Gustavo Justino de Oliveira classificam os consórcios públicos, conforme sua composição, em homogêneos ou horizontais e heterogêneos ou verticais, e também em bilaterais ou multilaterais. ${ }^{358}$ Homogêneos ou horizontais são os consórcios celebrados entre entes da mesma espécie, geralmente Municípios. Consórcios heterogêneos ou verticais envolvem, ao contrário, entes de diferentes níveis da Federação. De outra parte, o consórcio será bilateral ou multilateral conforme reúna, respectivamente, dois ou mais partícipes.

O representante do consórcio é o Chefe do Poder Executivo de qualquer um dos entes da Federação consorciados, eleito pelos integrantes do consórcio, nos termos previstos no protocolo de intenções. Seu mandato poderá se estender por mais de um exercício financeiro, nos termos do previsto no contrato de consórcio, cessando automaticamente se o representante vier a perder a condição de Chefe do Executivo. ${ }^{359}$

\subsection{Protocolo de intenções}

De acordo com o art. $3 .^{\circ}$ da Lei de Consórcios Públicos, a contratação do consórcio depende da prévia subscrição de um protocolo de intenções. A exigência mostra-se razoável, tendo em vista que o ingresso de cada partícipe no consórcio depende de ratificação legislativa (art. 5. ${ }^{\circ}$ ). Assim, natural que o representante do Executivo subscreva um texto preliminar - o protocolo de intenções -, o qual será apreciado pelo Legislativo daquele ente federado, que poderá ratificá-lo com ou sem reservas (art. $5 .^{\circ}, \S 2 .^{\circ}$ ), ou rejeitá-lo.

A doutrina debate a natureza jurídica do protocolo de intenções. Para Edmir Netto de Araújo, não se trata de "instrumento contratual, nem convênio, nem consórcio na acepção tradicional". 360 José dos Santos Carvalho Filho, por sua vez, vislumbra no protocolo de intenções um "acordo plurilateral prévio", em cujo âmbito "são previamente

\footnotetext{
${ }^{358}$ MEDAUAR; OLIVEIRA, 2006, p. 66-67.
}

359 ALVES, Vladimir. Comentários à lei dos consórcios públicos. São Paulo: Universitária de Direito, 2006. p. 94. O autor sustenta, entretanto, que a duração do mandato será definida pelo estatuto, o que, a nosso ver, afrontaria o art. $4^{\circ}$, VIII, da Lei n. $.^{\circ} 11.107 / 05$.

\footnotetext{
${ }^{360}$ ARAÚJO, 2007, p. 247.
} 
definidos direitos e obrigações dos futuros consorciados", não gerando, contudo, obrigação à celebração do contrato de consórcio. ${ }^{361}$

Como o próprio nome diz, o instrumento apenas registra as intenções dos signatários no sentido de criar um consórcio público, delineando seu funcionamento, seus objetivos, suas prerrogativas e deveres, mas sem gerar efeitos jurídicos concretos. Do ponto de vista de cada partícipe, o protocolo assemelha-se a um projeto de lei de iniciativa do Executivo, submetendo-se ao trâmite previsto para o processo legislativo. Sob um enfoque externo, o protocolo seria uma espécie de contrato preliminar, cujo descumprimento não acarreta ônus aos subscritores.

$\mathrm{O}$ art. $4 .^{\circ}$ da lei enumera uma lista de cláusulas que devem obrigatoriamente constar dos protocolos de intenções. Tais cláusulas fornecem as linhas mestras dos consórcios públicos no direito brasileiro, pelo que se faz importante tê-las em vista:

Art. $4^{\circ}$. São cláusulas necessárias do protocolo de intenções as que estabeleçam:

I - a denominação, a finalidade, o prazo de duração e a sede do consórcio;

II - a identificação dos entes da Federação consorciados;

III - a indicação da área de atuação do consórcio;

IV - a previsão de que o consórcio público é associação pública ou pessoa jurídica de direito privado sem fins econômicos;

$\mathrm{V}$ - os critérios para, em assuntos de interesse comum, autorizar o consórcio público a representar os entes da Federação consorciados perante outras esferas de governo;

VI - as normas de convocação e funcionamento da assembléia geral, inclusive para a elaboração, aprovação e modificação dos estatutos do consórcio público;

${ }^{361}$ CARVALHO FILHO, 2009, p. 22, 68, 89. 
VII - a previsão de que a assembléia geral é a instância máxima do consórcio público e o número de votos para as suas deliberações;

VIII - a forma de eleição e a duração do mandato do representante legal do consórcio público que, obrigatoriamente, deverá ser Chefe do Poder Executivo de ente da Federação consorciado;

IX - o número, as formas de provimento e a remuneração dos empregados públicos, bem como os casos de contratação por tempo determinado para atender a necessidade temporária de excepcional interesse público;

$\mathrm{X}$ - as condições para que o consórcio público celebre contrato de gestão ou termo de parceria;

XI - a autorização para a gestão associada de serviços públicos, explicitando:

a) as competências cujo exercício se transferiu ao consórcio público;

b) os serviços públicos objeto da gestão associada e a área em que serão prestados;

c) a autorização para licitar ou outorgar concessão, permissão ou autorização da prestação dos serviços;

d) as condições a que deve obedecer o contrato de programa, no caso de a gestão associada envolver também a prestação de serviços por órgão ou entidade de um dos entes da Federação consorciados;

e) os critérios técnicos para cálculo do valor das tarifas e de outros preços públicos, bem como para seu reajuste ou revisão; e

XII - o direito de qualquer dos contratantes, quando adimplente com suas obrigações, de exigir o pleno cumprimento das cláusulas do contrato de consórcio público.

Para Lílian Maria Salvador Guimarães Campos, outros assuntos também devem constar do protocolo de intenções, como "as formas de alteração e extinção do protocolo" e 
“a possibilidade de suspensão, de retirada por vontade própria ou mesmo de exclusão de entidade consorciada", bem como o "ingresso de novas entidades ao grupo". ${ }^{362}$

O importante é que o protocolo de intenções contenha todas as informações relevantes para que o Poder Legislativo de cada ente compromissado possa deliberar sobre tais escolhas. De outra forma, a exigência de ratificação legislativa restaria inócua, já que seria possível a formalização do compromisso de constituição de consórcio público em termos genéricos, cuja aprovação parlamentar entregaria ao Executivo um cheque em branco.

A teor do art. $4^{\circ}, \S 5^{\circ}$, da Lei de Consórcios Públicos, o protocolo de intenções tem de ser publicado na imprensa oficial. Trata-se de condição de eficácia do negócio. ${ }^{363} \mathrm{~A}$ norma é salutar, na medida em que prestigia o princípio da publicidade na atividade administrativa. $\mathrm{O}$ dispositivo é complementado pelo art. $5^{\circ}, \S 8^{\circ}$, do Decreto Federal n. ${ }^{\circ}$ 6.017/07, que faculta seja a publicação feita de forma resumida, desde que indique o endereço da internet em que se poderá obter o texto integral. Seria desmedido, a nosso sentir, acusar a norma administrativa de ter transbordado os limites da lei, ampliando a liberdade dos responsáveis pelo consórcio. Isso porque a publicação do resumo do protocolo na imprensa oficial já cumpre o objetivo de divulgá-lo, a exemplo do que se faz com os contratos administrativos em geral. Além disso, dada a crescente difusão da rede mundial de computadores, pode-se supor que os eventuais interessados em examinar o conteúdo do contrato preliminar terão facilidade em obtê-lo, isso se o próprio diário oficial já não tiver circulação somente em versão eletrônica, na internet - embora fosse prudente também que a publicação indicasse uma repartição pública onde se poderia conseguir cópia do protocolo.

\subsection{Necessidade de ratificação legislativa}

De acordo com a Lei n. ${ }^{\circ} 11.107 / 05$, a ratificação do protocolo de intenções se dá por lei de cada ente federado. É possível também que, antes mesmo da subscrição do

\footnotetext{
${ }^{362}$ CAMPOS, 2006, p. 101.

${ }^{363}$ Ibid., p. 102.
} 
protocolo de intenções, o ente federado edite uma lei disciplinando sua participação no consórcio público (naquele consórcio específico que se pretende formar, já que a lei utiliza-se do vocábulo "no"). Conclui-se, portanto, que a Lei n. ${ }^{\circ}$ 11.107/05 optou claramente pela necessidade de lei específica para a constituição do consórcio público, seja ela anterior ou posterior ao ato administrativo consistente na subscrição do protocolo de intenções.

A autorização legislativa para celebração de convênios e consórcios já vinha sendo exigida por muitos municípios paulistas, em suas leis orgânicas, até por influência da anterior lei orgânica de todos eles, Decreto-lei Estadual n. ${ }^{\circ}$ 9, de 31 de dezembro de 1969, em seu art. 24, XII. Enquanto alguns autores, como Hely Lopes Meirelles, viam a exigência como adequada, por se referir a "atos gravosos que extravasam dos poderes normais do administrador público", 364 outros, como Maria Sylvia Zanella Di Pietro, apontavam aí uma ingerência indevida do Legislativo em assuntos do Executivo, por alheia aos casos previstos na Constituição - exceto quando houvesse repasse de recursos não previstos no orçamento. ${ }^{365}$ O Supremo Tribunal Federal também enxergou, em diversas oportunidades, essa inconstitucionalidade. ${ }^{366}$

Benedicto Porto Neto sustenta a necessidade de autorização legislativa para a celebração de um consórcio público ou mesmo de um convênio de cooperação, com base na noção de que toda atividade administrativa se submete ao princípio da legalidade. ${ }^{367}$

Em sentido contrário, Dinorá Adelaide Musetti Grotti, diante da então recente promulgação da Emenda Constitucional n. ${ }^{\circ}$ 19/98, que inseriu a menção aos consórcios públicos e convênios de cooperação no art. 241, posicionou-se no sentido de que passara a ser indubitavelmente desnecessária a autorização legislativa para a celebração de cada

\footnotetext{
${ }^{364}$ MEIRELLES, 2003, p. 387.

${ }^{365}$ DI PIETRO, 2005b, p. 302.

${ }^{366}$ RDA 140/68, abr/jun 1980; ADIn n. ${ }^{\circ}$ 342/PR, Rel. Min. Sydney Sanches, DJ 11.04.2003; ADIn n. ${ }^{\circ}$ 770/MG, Rel. Min. Ellen Gracie, DJ 20.09.2002; ADIn n. ${ }^{\circ}$ 462/BA, Rel. Min. Moreira Alves, DJ 18.02.2000; ADIn n. ${ }^{\circ}$ 676/RJ, Rel. Min. Carlos Velloso, DJ 29.11.1996; Representação de Inconstitucionalidade $\mathrm{n} .{ }^{\circ}$ 1.024/GO, Rel. Min. Rafael Mayer, DJ 30.05.1980, Representação de Inconstitucionalidade n..$^{\circ}$ 1.210-7/RJ, Rel. Min. Moreira Alves, DJ 07.06.1985; ADIn n..$^{\circ}$ 177/RS, Rel. Min. Carlos Velloso, DJ 25.10.1996; ADIn n. ${ }^{\circ}$ 165/MG, Rel. Min. Sepúlveda Pertence, DJ 26.09.1997; ADIn n. ${ }^{\circ}$ 1.857/SC, Rel. Min. Moreira Alves, DJ 23.10.1998.

${ }^{367}$ PORTO NETO, 2005.
} 
convênio, bastando a edição de lei que definisse as características da gestão associada de serviços públicos. ${ }^{368}$

É inequívoco que o entendimento jurisprudencial sobre a desnecessidade de permissão legislativa para a pactuação de convênios firmara-se em relação aos convênios e consórcios como acordos de vontade, e não como pessoas jurídicas. De fato, a concepção de um consórcio como pessoa jurídica, criada pelos entes partícipes do ajuste, obriga a novas reflexões sobre a necessidade de autorização legislativa.

Sob a disciplina jurídica atualmente aplicável aos consórcios públicos, parece não haver dúvida de que, em se tratando de consórcio com personalidade jurídica de direito público, a previsão de autorização legislativa, em cada caso, tem razão de ser, diante do art. 37, XIX, da Constituição Federal, que exige lei para a criação de autarquia. ${ }^{369}$ Além disso, o consórcio muitas vezes implica gastos não previstos no orçamento, extrapolando a atuação ordinária do Poder Executivo. ${ }^{370}$

Mesmo quanto aos consórcios com personalidade de direito privado, que não se constituem em autarquia, a polêmica deve ceder, sendo igualmente inaplicável a mencionada jurisprudência do Supremo Tribunal Federal, haja vista que a criação de uma nova pessoa integrante da administração indireta, à qual se transferem competências e, eventualmente, bens e pessoal, não pode ser tida como inerente às prerrogativas do Poder Executivo.

Por outro lado, deve-se afastar a possibilidade de edição de medida provisória para ratificar o protocolo, uma vez que esta evidentemente não se compatibiliza com a natureza de controle parlamentar que tem o ato de ratificação. ${ }^{371}$

O Legislativo pode ratificar o protocolo de intenções com reservas, ou seja, desobrigando o ente federado de respeitar determinadas cláusulas (art. 5., § 2. ${ }^{\circ}$, da Lei n. ${ }^{\circ}$ 11.107/05). Essas ressalvas, por significarem a alteração do inicialmente compromissado, acabam por afetar os demais entes, motivo pelo qual a ratificação parcial depende da

\footnotetext{
${ }^{368}$ GROTTI, 2003, p. 211.

${ }^{369}$ Cf. MEDAUAR; OLIVEIRA, 2006, p. 71.

${ }^{370}$ CAMPOS, 2006, p. 103.

${ }^{371}$ Nesse mesmo sentido, CARVALHO FILHO, 2009, p. 89.
} 
aceitação destes, que se deve dar de modo expresso. O Decreto n. ${ }^{\circ}$ 6.017/07 dispõe que, quando o consórcio tiver mais de um objetivo, o ente federado não precisa consorciar-se em relação a todos eles $\left(\operatorname{art.} 3^{\circ}, \S 1^{\circ}\right)$.

Além do consorciamento parcial, no qual se dá a não-incidência das cláusulas ressalvadas, é também possível o consorciamento condicional, em que se adere a determinada cláusula sob certa condição. ${ }^{372}$

A fim de se evitarem maiores delongas no procedimento de formação do consórcio público, o protocolo de intenções pode desde logo estipular a vedação de determinadas ressalvas. Vale dizer, o próprio texto preliminar já poderia estabelecer, com supedâneo na autonomia de vontade de cada ente, quais as disposições imprescindíveis para o funcionamento do consórcio tal como planejado, já que os entes consorciados precisariam, de todo modo, aceitar as reservas que um deles porventura fizesse.

O ente compromissado não pode ratificar o consórcio a qualquer tempo, conforme sua conveniência. Com efeito, a aprovação tardia do protocolo de intenções, após a realização de investimentos pelos outros entes e a entrada em funcionamento do consórcio, poderia afetar o equilíbrio entre os partícipes, acarretando um benefício desproporcional ao mais recente integrante. Assim, houve por bem o legislador limitar o juízo de oportunidade da ratificação, resolvendo que, passados dois anos da subscrição do protocolo de intenções, a aprovação tardia precisará ser homologada pela assembléia geral do consórcio público (art. 5. ${ }^{\circ}, \S 3 .^{\circ}$, da lei).

Essa observação leva a uma segunda conclusão: uma vez assinado o protocolo de intenções, é necessário que, dentro de dois anos, ao menos dois entes compromissados obtenham a aprovação legislativa e ponham em funcionamento o consórcio. Isso porque, assim não sendo, não há mais como a assembléia geral homologar a ratificação que um dos entes tenha obtido após dois anos de sua subscrição do protocolo de intenções. Ora, se o consórcio, em dois anos, não chegou a se formar, a partir daí torna-se impossível sua constituição, por inexistência de uma assembléia geral que, nos termos do art. $5 .^{\circ}, \S 3 .^{\circ}$, da lei, homologue a ratificação tardia dos interessados.

${ }^{372}$ CARVALHO FILHO, 2009, p. 92. 
Questão interessante se coloca a respeito do momento em que surge a pessoa jurídica consorcial. Para Marcelo Harger, isso se dá quando todas as leis ratificadoras entram em vigor, ou quando o número suficiente de leis entra em vigor, caso o protocolo assim o preveja. ${ }^{373}$

Maria Sylvia Zanella Di Pietro entende que, em tese, a personalidade jurídica surge em momentos diferentes para cada partícipe, conforme ratifiquem o protocolo de intenções. A incongruência poderia resolver-se com o entendimento "de que o consórcio adquire personalidade jurídica com a lei ratificadora, sob condição resolutiva da celebração do contrato de consórcio". 374

José dos Santos Carvalho Filho argumenta que a aquisição de personalidade jurídica em momentos diferentes ofenderia o princípio de que a pessoa jurídica "é uma e só pode ter um momento para início de sua personalidade”. Defende, assim, que a pessoa jurídica tem início "com a vigência da última lei de ratificação do protocolo de intenções". 375

De fato, não parece ser possível a existência "relativa" da pessoa jurídica, apenas para uma entidade e não para outra, conforme o momento de aprovação legislativa. $\mathrm{O}$ art. $6^{\circ}$, I, da Lei de Consórcios Públicos exige para o surgimento da personalidade jurídica a vigência não da lei, mas “das leis de ratificação do protocolo de intenções”. A princípio, portanto, parece necessária a vigência de todas elas. Nada impede, porém, que o próprio protocolo preveja um número suficiente de ratificações para criar a pessoa consorcial, dado o permissivo contido no art. $5^{\circ}, \S 1^{\circ}$, da lei:

$\S 1^{\circ}$. O contrato de consórcio público, caso assim preveja cláusula, pode ser celebrado por apenas 1 (uma) parcela dos entes da Federação que subscreveram o protocolo de intenções.

\footnotetext{
${ }^{373}$ HARGER, 2007, p. 161-162.

374 DI PIETRO, 2008, p. 242-243. Com a devida vênia, entendemos que, na hipótese, cuidar-se-ia de condição suspensiva, eis que os efeitos estariam a princípio sustados e somente se iniciariam em momento posterior, quando da celebração do contrato.

${ }^{375}$ CARVALHO FILHO, 2009, p. 30-31.
} 
Quanto à possibilidade legalmente prevista de dispensa de ratificação, com base na prévia edição de lei que regulamente a participação do ente federado no consórcio, sublinhe-se que não só essa lei deverá referir-se ao consórcio específico ao qual se pretende aderir, como precisará apresentar "conteúdo coincidente com o que venha a constar do contrato de protocolo" a ser subscrito por outros entes, "ajustando-se, inclusive, à detalhada relação de cláusulas necessárias" do ajuste preliminar. ${ }^{376}$ Caso contrário, não se compatibilizará com o consórcio que pretende integrar.

\subsection{Formalização e publicação do contrato}

Após a ratificação legislativa do protocolo de intenções, que, no caso das associações públicas, já origina a pessoa jurídica consorcial - sendo ainda necessário, para os consórcios que almejam personalidade jurídica de direito privado, o registro civil -, mostra-se recomendável, embora a lei silencie a respeito, a formalização de um contrato, cujo extrato ou íntegra seja publicado ou registrado em algum cartório, ${ }^{377}$ de modo a atender-se o princípio da transparência.

Na verdade, o contrato é celebrado com a "ratificação, mediante lei, do protocolo de intenções" (art. $5^{\circ}$ da Lei n. ${ }^{\circ}$ 11.107/05), fazendo surgir, de pleno direito, a personalidade jurídica da associação pública (art. $6^{\circ}$, I). Assim, não parece tecnicamente correto falar-se na celebração do contrato após a ratificação legislativa, como defendem alguns autores, ${ }^{378}$ mas sim na formalização de um termo que reúna todas as condições aprovadas pelo Legislativo de cada partícipe, assim como as ressalvas porventura opostas por um deles e aprovadas pelos demais, consolidando-se desse modo as normas que regerão o consórcio durante toda a sua vigência.

Com efeito, se a ratificação das leis já dá origem às relações jurídicas consubstanciadas no advento da associação pública, nenhum outro direito resta para ser criado por uma ulterior "celebração de contrato" - mas tão-somente atos materiais

\footnotetext{
${ }^{376}$ Ibid., p. 92.

${ }^{377}$ ARAÚJO, 2007, p. 248.

${ }^{378}$ Cf. HARGER, 2007, p. 160-161; CAMPOS, 2006, p. 104.
} 
implementadores da vontade contratual -, e por isso mesmo não faria sentido falar num contrato, a cujo conceito é inerente a instituição de relações jurídicas vinculantes.

Importante anotar a posição de Marcelo Harger, para quem a celebração do contrato teria eficácia similar à dos decretos que, amparados em lei criadora de autarquia, instituem essa mesma autarquia, viabilizando seu funcionamento administrativo, inclusive pela elaboração dos estatutos. ${ }^{379}$ Permitimo-nos ressalvar o entendimento de que, como já dito, não parece apropriado falar-se numa "celebração de contrato" após a ratificação legislativa. De todo modo, é de fato razoável admitir-se que o procedimento de formalização e publicação do contrato funcione como marco a partir do qual se estrutura o consórcio, possibilitando-se a elaboração de seus estatutos, em estrita observância ao definido no contrato (art. $8^{\circ}$ do Decreto n. ${ }^{\circ}$ 6.017/07).

Feita a formalização, o termo de contrato, ou ao menos um extrato dele, deve ser dado a conhecer à sociedade no mínimo por intermédio de publicação na imprensa oficial de cada partícipe, mas de preferência também nos respectivos sítios na internet e em jornal diário de grande circulação na área do consórcio (por aplicação analógica do art. 21, III, da Lei n. ${ }^{\circ} 8.666 / 93$ e dos arts. $5^{\circ}, \S 8^{\circ}$, e $8^{\circ}, \S 4^{\circ}$, do Decreto n. $\left.{ }^{\circ} 6.017 / 07\right)$, tudo em observância ao art. 37, caput, da Constituição Federal, que consagra o princípio da publicidade na administração pública.

${ }^{379}$ HARGER, op. cit., p. 161. 


\section{ATUAÇÃO DO CONSÓRCIO PÚBLICO}

\section{1. Área de atuação}

$\mathrm{O}$ art. $4 .^{\circ}, \S 1 .^{\circ}$, da Lei n. ${ }^{\circ} 11.107 / 05$ define qual será considerada a área de atuação do consórcio público: (i) a soma dos territórios “dos Municípios, quando o consórcio público for constituído somente por Municípios ou por um Estado e Municípios com territórios nele contidos"; (ii) a soma dos territórios "dos Estados ou dos Estados e do Distrito Federal, quando o consórcio público for, respectivamente, constituído por mais de 1 (um) Estado ou por 1 (um) ou mais Estados e o Distrito Federal"; ou (iii) a soma dos territórios “dos Municípios e do Distrito Federal, quando o consórcio for constituído pelo Distrito Federal e os Municípios".

Os dispositivos que previam que a área de atuação do consórcio seria aquela correspondente à totalidade dos territórios dos Municípios e dos Estados, quando o consórcio público fosse integrado por um ou mais Estados e Municípios, e dos Municípios, Distrito Federal e Estados, quando o consórcio fosse formado pelo Distrito Federal, um ou mais Estados e Municípios foram vetados, pelos motivos já vistos, ${ }^{380}$ relacionados à composição do consórcio.

\subsection{Objeto}

Os consórcios públicos podem ter por objeto variadas atividades inseridas no âmbito da administração e prestação de serviços públicos. O art. $1 .^{\circ}$, caput, da Lei de Consórcios fala na "realização de objetivos de interesse comum", o que poderia ser traduzido como a gestão associada de serviços públicos, a teor do art. 241 da Constituição.

\footnotetext{
${ }^{380}$ Cf. item 7.2 supra.
} 
Com efeito, a gama de atividades empreendidas pelo consórcio não pode escapar ao conceito constitucional de "serviço público", haja vista a expressa previsão do art. $241 .{ }^{381}$

Assim é que, no Brasil, diferentemente do que se passa em diversos países, a constituição de pessoas jurídicas para cooperação interadministrativa restringe-se ao campo da gestão associada de serviços públicos, não podendo extravasar para as outras atividades típicas da administração, como, por exemplo, o poder de polícia ou a intervenção no domínio econômico.

Isso porque, conquanto a Lei Maior se reporte a "serviço público" em distintas acepções, ora para designar o próprio aparato estatal, ora "uma espécie de atividade que pode ser prestada diretamente pelo Estado ou por intermédio de delegação a particulares”, ou ainda atividades de responsabilidade do Poder Público que podem, todavia, ser exercidas por particulares independentemente de delegação, ${ }^{382}$ a interpretação sistemática das normas que tratam do serviço público na Constituição de 1988 induz à conclusão de que tal expressão não é utilizada indistintamente, para referir qualquer tipo de atividade exercida pelo Estado. ${ }^{383}$ No mínimo seria possível enxergar com nitidez a intenção de se reservarem certas atividades preferencialmente à iniciativa privada, vale dizer, a "atividade econômica em sentido estrito". 384

Assim, deve o intérprete delimitar, dentro do possível - dada a inviabilidade de uma conceituação precisa e imutável, como se verá -, o alcance do termo "serviço público" para os fins da instituição de um consórcio público.

\subsubsection{Serviço público}

O conceito de serviço público, matéria amplamente debatida na doutrina do direito administrativo, só pode ser compreendido historicamente.

\footnotetext{
${ }^{381}$ Nesse sentido, CAMPOS, 2006, p. 87.

${ }^{382}$ HARGER, 2007, p. 43-44.

383 Defendendo conceito restritivo de serviço público para efeitos do art. 241 da Constituição Federal, cf. HARGER, 2007, p. 100.
} 
Inicialmente, o Poder Público centrava sua atuação no poder de polícia, raramente se comprometendo com a prestação de benesses à coletividade.

Foi principalmente a partir da metade do século XIX que a administração passou a assumir a prestação de serviços públicos, o que, na lição de Fernando Garrido Falla, se dá em três etapas: a administração como prestadora de serviços assistenciais; a administração como titular de serviços de caráter econômico; e a administração como gestora de empresas econômicas. ${ }^{385}$

Na primeira etapa, o Estado passa a assumir atividades de beneficência (aos poucos tomadas da Igreja) e de educação (haja vista o princípio então nascente do ensino geral e obrigatório), assim como os serviços sanitários. Em nenhum caso, todavia, impediu-se a prestação paralela de tais serviços pelos particulares, de forma que não se colocava a figurava da concessão de serviço público, embora desde sempre houvesse significativa interferência do poder de polícia estatal sobre tais atividades. ${ }^{386}$

A segunda etapa trazia a dificuldade de se conceber a exploração de um serviço passível de exploração econômica pelo Estado, o que se resolveu, em parte, pela fórmula da concessão: a exploração empresarial do serviço ficava por conta do particular, ao mesmo tempo que se estabelecia "el dogma de la titularidad administrativa del servicio (a favor de la Administración concedente)", ou seja, a concessão não era apenas uma escolha de gestão, mas um artifício essencial ao sistema. ${ }^{387}$

Note-se que, em países como os Estados Unidos, esse período demarcou um distanciamento em relação à evolução da atuação estatal ocorrida nos países da "civil law", eis que, em vez de se atribuir ao Estado a prestação de serviços públicos econômicos, preferiu-se expandir o poder de polícia para regulamentar intensamente as "public utilities" (empresas privadas de interesse público), a ponto de se colocarem em situação bastante similar à das nossas conhecidas concessionárias de serviços públicos. ${ }^{388}$

\footnotetext{
${ }^{384}$ GRAU, Eros Roberto. A ordem econômica na Constituição de 1988. 7. ed. São Paulo: Malheiros Editores, 2002. p. 140-141.

${ }^{385}$ GARRIDO FALLA, 1989, v. 2, p. 321-325.

${ }^{386}$ Ibid., p. 322.

${ }^{387}$ Ibid., p. 323.

${ }^{388}$ Ibid., loc. cit. Nota de rodapé n. 5.
} 
Mas, segundo o renomado autor espanhol, a maior mudança foi a que adveio da terceira etapa. Já não bastava o reconhecimento da titularidade do Estado sobre determinados serviços econômicos, mas surgia também a consagração da competência para geri-los diretamente, através das empresas públicas. ${ }^{389}$

Nessa época, Gastón Jèze começava a falar da possibilidade de o Parlamento criar “estabelecimentos públicos”, ou seja, entidades personalizadas, com patrimônio próprio afetado à gestão de um serviço público. ${ }^{390}$

No esteio dessas mudanças havidas na concepção do papel do Estado ao longo da história, e especialmente por conta da complexidade que o tema foi ganhando no século XX, foi-se modificando a noção de serviço público.

O francês Léon Duguit foi o teórico a quem se pode atribuir a iniciativa pela mudança de enfoque do direito público, que migrou da noção de soberania e "puissance publique" para a idéia de deveres do Estado, cujo cumprimento é pressuposto do exercício de qualquer poder. Em outras palavras, deslocou-se o foco para a noção de serviço público: "la notion de service public devient la notion fondamentale du droit public moderne". ${ }^{391}$

Para Duguit, nunca se pode governar por si mesmo: o importante não é a força material de quem exerce o direito, mas o modo como ele é exercido, e o que se encontra por trás dessa força. ${ }^{392} \mathrm{O}$ exercício do poder pelo Estado somente se legitima se tende a realizar os deveres impostos aos governantes, que se resumem à obrigação de assegurar, de maneira permanente, o funcionamento dos serviços públicos. ${ }^{393}$

O autor constrói, a partir de tais considerações, uma noção de serviço público baseada na solidariedade e interdependência sociais, defendendo que todos, desde o camponês mais simples até o monarca, devem contribuir sem interrupção, para que a

\footnotetext{
${ }^{389}$ GARRIDO FALLA, 1989, v. 2, p. 324-325.

390 JÈZE, Gaston. Principios generales del derecho administrativo. Buenos Aires: Depalma, 1949. v. 2, p. 29-37.

391 DUGUIT, Léon. Les transformations du Droit public, apud DUGUIT, Léon. Leçons de Droit public général. 2. ed. Paris: E. de Boccard, 1926. p. 152. Em tradução livre, "a noção de serviço público torna-se a noção fundamental do direito público moderno".

392 DUGUIT, 1926, p. 141.

${ }^{393}$ Ibid., p. 148, 150-151.
} 
sociedade não corra o risco de se desorganizar e perecer. ${ }^{394}$ Até hoje a concepção da interdependência social orienta a noção material de serviço público, como se extrai, por exemplo, da obra de Eros Roberto Grau. ${ }^{395}$

Duguit englobava, no conceito de serviço público, toda a atividade estatal, que, de início, identificava-se com a guerra, polícia e justiça, e, posteriormente, passava a abranger inúmeros serviços de caráter técnico, industrial e comercial, como a iluminação elétrica, telefonia e estradas de ferro, cuja manutenção era reconhecida como indispensável à vida nacional. $^{396}$

Para Gastón Jèze, que deu continuidade à Escola do Serviço Público inaugurada por Duguit, existem necessidades de interesse geral satisfeitas pelos particulares, pela Administração, ou por ambos, concorrentemente. A Administração, para satisfazer essas necessidades, poderia, em tese, usar procedimentos de direito privado e de direito público, sendo certo que o serviço público propriamente dito só tem lugar quando os agentes públicos, para atenderem certa categoria de necessidades de interesse geral, podem aplicar esse procedimento de direito público. ${ }^{397}$ Sob esse raciocínio, somente seria adequado o emprego da expressão "serviço público" nos casos em que, "para satisfacer determinada necesidad de interés general, los agentes públicos pueden recurrir, para los procedimientos del derecho público, a reglas que están fuera de la órbita del derecho privado", e não para casos em que se possa utilizar exclusivamente procedimentos de direito privado, hipótese em que se empregaria o termo "gestão administrativa" ou equivalente. ${ }^{398}$

O autor francês também prestigiava uma concepção bastante abrangente de serviço público, que incluía, por exemplo, a fabricação de pólvora, tabaco e fósforo, realizada em regime de monopólio, pois entendia que a atribuição de monopólio era um claro sinal de que o Estado considerava a atividade como serviço público. ${ }^{399}$

\footnotetext{
${ }^{394}$ DUGUIT, 1926, p. 150.

${ }^{395}$ GRAU, 2002, p. 165-166.

${ }^{396}$ DUGUIT, 1926, p. 151.

${ }^{397}$ JÈZE, 1949, v. 2, p. 3-4.

398 Ibid., p. 9-10. Uma possível tradução para o trecho copiado seria: "para satisfazer determinada necessidade de interesse geral, os agentes públicos podem recorrer, para os procedimentos de direito público, a regras que estão fora da órbita do direito privado".

${ }^{399}$ Ibid., p. 23.
} 
A conceituação original de serviço público apresentava, assim, os elementos orgânico, material e formal. $O$ primeiro consistia na idéia de que era o Estado quem prestava a atividade; o segundo baseava-se na necessidade de que o serviço se prestasse a satisfazer necessidades coletivas; e o último consagrava a concepção de que o serviço era exercido sob regime publicista, derrogatório do direito comum. ${ }^{400}$ A modificação desses elementos ao longo do tempo deu a tônica da evolução da noção de serviço público, havendo doutrinadores que emprestavam relevo ora a um dos critérios, ora a outro, e freqüentemente a todos eles, como sói acontecer ainda hoje.

Aos poucos, a acepção de serviço público se foi tornando mais específica, para designar não toda a atividade estatal, mas somente uma parte dela. Assim é que, de início, cuidou-se da especificação do serviço público como atividade da Administração, e portanto inconfundível com as funções legislativa e jurisdicional. O passo seguinte seria separar o serviço público de outras atividades levadas a efeito pela Administração.

Os autores italianos Guido Zanobini ${ }^{401}$ e Massimo Severo Giannini ${ }^{402}$ distinguem o serviço público da função pública. Para Giannini, a titularidade das funções públicas é necessariamente do Estado; já a competência sobre os serviços se define por razões técnicas, econômicas ou sociais, nada impedindo que sua gestão se dê por particulares.

Renato Alessi identifica o serviço público como a atividade estatal dirigida a produzir utilidade aos particulares, utilidade essa que poderia ser jurídica ou econômicosocial. $^{403}$

Ainda se encontra na obra de alguns autores pátrios, como Hely Lopes Meirelles, um conceito de serviço público que não permite uma rigorosa delimitação em relação a outras atividades da Administração. Para o citado autor, "serviço público é todo aquele prestado pela Administração ou por seus delegados, sob normas e controles estatais, para

${ }^{400}$ DI PIETRO, 2005b, p. 97.

401 ZANOBINI, Guido. Corso di diritto amministrativo, vol. I, 1947, p. 14-15, apud GARRIDO FALLA, 1989 , v. 2, p. 327-328.

402 GIANNINI, Massimo Severo. Lezioni di diritto amministrativo, vol. I, pp. 114/115, apud GARRIDO FALLA, 1989, v. 2, p. 327-328.

403 ALESSI, Renato. Diritto amministrativo, I, 1949, pp. 329 e ss., apud GARRIDO FALLA, 1989, v. 2, p. 327-328. 
satisfazer necessidades essenciais ou secundárias da coletividade ou simples conveniências do Estado". 404

Na Argentina, José Roberto Dromi entende compatível com aquela ordem constitucional a noção ampla de serviço público como "toda actividad del Estado cuyo cumplimiento debe ser asegurado, regulado y controlado". 405

Fernando Garrido Falla adota conceito mais restrito de serviço público, para contrastar com as atividades estatais de coação e fomento. Para ele, serviço público é a "actividad de prestación dirigida a proporcionar utilidad a los particulares, que viene impuesta cabalmente por razones de interés público". 406

Dadas as variações sofridas na acepção de serviço público ao longo dos anos, que refletiram, de regra, a tendência de reduzir a amplitude do conceito, ou de contrastá-lo com as inovações das técnicas de direito administrativo - as quais por sua vez espelhavam a evolução do papel do Estado -, muito se falou, no século passado, em uma "crise da noção de serviço público".

Ora, se o conceito de serviço público abrangia todo o direito administrativo, era evidente que qualquer mudança que se desse mais cedo ou mais tarde na estrutura desse ramo do direito provocaria um desajuste entre os termos, o que de fato aconteceu, sobretudo quando a Administração passou a se tornar gestora de empresas e atividades comerciais e industriais. ${ }^{407}$

Pode-se dizer assim, como Marcelo Harger, que as chamadas crises da noção de serviço público "apenas refletem o choque entre correntes ideológicas diversas procurando conceituar serviço público de acordo com a noção que cada qual possui acerca do papel do Estado perante a sociedade". ${ }^{408}$

Fazia mais sentido alardear a crise do conceito em países como a França, onde a noção ampla de serviço público cumpria também uma função delimitadora de

\footnotetext{
${ }^{404}$ MEIRELLES, 2003, p. 319.

${ }^{405}$ DROMI, 1996, p. 529.

${ }^{406}$ GARRIDO FALLA, 1989, v. 2, p. 328.

${ }^{407}$ Ibid., p. 329.

${ }^{408}$ HARGER, 2007, p. 33.
} 
competências jurisdicionais: servia para identificar as matérias afetas ao contencioso administrativo. Mais que isso, a atividade tida como serviço público era aquela que justificava a incidência das normas especiais de ordem pública, e daí a importância de seu reconhecimento como tal. ${ }^{409}$ Sendo assim, foi inevitável que a nova atividade mercantil e industrial do Poder Público, bem como a prestação de serviços tidos como públicos por particulares, abalassem as normas de competência, colocando em cheque a própria idéia de serviço público. ${ }^{410}$

No Brasil, particularmente, a noção de serviço público não é inócua, sobretudo quando se tem em vista a larga utilização constitucional do termo. ${ }^{411}$

Conquanto o conceito tenha sofrido mutações em seu conteúdo, pode-se afirmar que o serviço público traz sempre a idéia de prestação de titularidade do Poder Público que visa à satisfação de necessidades coletivas, ${ }^{412}$ e que se dá sob regime total ou parcialmente público. $^{413}$

O fato de tais atividades serem de titularidade do Estado não significa que não possam ser prestadas pelos particulares, por meio dos pertinentes instrumentos jurídicos de delegação de serviços públicos. Nos casos em que o ordenamento permite ao particular o exercício de certas atividades de interesse público sem a utilização desses instrumentos, tem-se entendido não se estar, propriamente, diante de um serviço público.

Ao contrário do que entende a maior parte da doutrina, para a qual essas atividades abertas à iniciativa privada só são consideradas serviço público quando exercidas pelo Estado, Eros Roberto Grau defende que também os particulares prestam serviços públicos quando atuam em áreas na área da saúde ou da educação, independentemente de concessão ou permissão do Poder Público. Trata-se do que ele chama de serviços públicos não privativos. Assim, a referida afirmação da titularidade estatal do serviço público seria

\footnotetext{
${ }^{409}$ JÈZE, 1949, v. 2, p. 12.

${ }^{410}$ GARRIDO FALLA, 1989, v. 2, p. 329-330.

${ }^{411}$ GROTTI, 2003, p. 88-89.

${ }^{412}$ CAMPOS, 2006, p. 91; GROTTI, 2003, p. 89.

${ }^{413}$ DI PIETRO, 2005b, p. 99.
} 
colocada em xeque. ${ }^{414}$ A questão encontra-se distante de uma solução doutrinária pacífica, e, por escapar ao objeto desta monografia, fica aqui apenas registrada.

Entre nós, atualmente, tem-se observado uma tendência à adoção de um conceito de serviço público que, ao passo que conjuga os clássicos critérios subjetivo, formal e material, ocupa-se em traçar a fronteira desse tipo de atividade estatal com relação a outras, desempenhadas tradicionalmente pelos Poderes Legislativo e Judiciário, assim como pelo próprio Poder Executivo. Assim fazem Maria Sylvia Zanella Di Pietro, para quem serviço público é "toda atividade material que a lei atribui ao Estado para que a exerça diretamente ou por meio de seus delegados, com o objetivo de satisfazer concretamente às necessidades coletivas, sob regime jurídico total ou parcialmente público"; ${ }^{415}$ Marcelo Harger, que embora se aproxime inicialmente de uma concepção eminentemente material, considera que é a Constituição que fornece os requisitos pelos quais uma atividade pode ser considerada serviço público, e conclui pela necessidade de reunião dos diferentes critérios aqui referidos para a sua conceituação como

a atividade de oferecimento de uma utilidade ou comodidade material aos cidadãos em geral, prestada pelo Estado ou por quem lhe faça as vezes, por intermédio de delegação, com o objetivo de atender a interesses individuais ou coletivos referentes à dignidade dos cidadãos ou evitar que os particulares que as desempenhem exerçam um poder excessivo sobre o restante da coletividade, e que, por essa razão, sujeitam-se a um regime jurídico especial, de Direito Público, mais rígido, que derroga as normas de Direito Privado; ${ }^{416}$

Celso Antônio Bandeira de Mello, que enuncia conceito ainda mais restrito de serviço público, excluindo atividades que não sejam diretamente fruíveis pelos

${ }^{414}$ GRAU, 2002, p. 153-154.

${ }^{415}$ DI PIETRO, 2005b, p. 99.

${ }^{416}$ HARGER, 2007, p. 35- 36, 59, 184. 
administrados; ${ }^{417}$ e Diógenes Gasparini, que, trabalhando sobre o conceito de Celso Antônio Bandeira de Mello, define serviço público como

\begin{abstract}
toda atividade de oferecimento de utilidade ou comodidade fruível preponderantemente pelos administrados, prestada pela Administração Pública ou por quem lhe faça as vezes, sob um regime de Direito Público, instituído em favor de interesses definidos como próprios pelo ordenamento jurídico. ${ }^{418}$
\end{abstract}

Pode-se notar certo consenso em torno da idéia de que o serviço público sempre visa à satisfação do interesse social. No entanto, como discernir quando se está diante do atendimento de um interesse social? Em outras palavras, como identificar um serviço público, no sentido estrito do termo?

Odete Medauar ${ }^{419}$ e Dinorá Adelaide Musetti Grotti ${ }^{420}$ ponderam - e de modo irretorquível - que a definição de uma dada atividade como serviço público é uma escolha política que remete ao plano do Estado e seu papel. Vale dizer, o serviço público é aquilo que os governantes de uma determinada época decidem que seja.

Com efeito, não parece haver um serviço público por essência. O serviço público é a atividade que a Constituição ou a lei ordinária definir como tal; cuida-se de decisão política. $^{421}$

No mesmo sentido, Fernando Garrido Falla entende que a definição de quando se dão as razões de interesse público a imporem a prestação de utilidades aos particulares é mais política que jurídica. ${ }^{422}$

\footnotetext{
${ }^{417}$ MELLO, 2006, p. 634.

${ }^{418}$ GASPARINI, 2006, p. 290.

${ }^{419}$ MEDAUAR, 2001, p. 369.

${ }^{420}$ GROTTI, 2003, p. 87.

${ }^{421}$ Ibid., p. 88.

${ }^{422}$ GARRIDO FALLA, 1989, v. 2, p. 328.
} 
Décadas atrás, Gastón Jèze ressaltava ser a intenção dos governantes que define o que é serviço público em determinada época, isto é, quais as atividades de interesse geral que devem ser satisfeitas mediante procedimentos de direito público. ${ }^{423}$ Essa intenção dos governantes se reconhece por meio de diversos indícios, ${ }^{424}$ não sendo possível ao jurista opinar sobre o que deve ou não ser considerado serviço público, algo que cabe unicamente aos governantes, restando aos doutrinadores, no máximo, lamentar. ${ }^{425}$

As palavras de Jèze ecoam no atual escólio de Dinorá Adelaide Musetti Grotti, para quem "a expressa referência constitucional de alguma atividade como serviço público elimina qualquer objeção que se pudesse fazer à sua identificação como tal" ${ }^{426}$

Seria possível dizer, então, que o legislador pode erigir qualquer categoria da atividade humana ao patamar de serviço público?

No Brasil, a resposta parece ser afirmativa em relação ao legislador constituinte. A interpretação do texto constitucional a partir de conceitos jurídicos pré-definidos, especificamente no caso da definição dos serviços públicos, nada mais seria que agir politicamente, a pretexto de se construir uma exegese do direito posto. Não parece razoável, sob esse raciocínio, que um jurista pretenda excluir do rol de serviços públicos uma atividade constitucionalmente definida como tal. Tanto pior que um juiz o faça, interferindo na opção daqueles que, supostamente, detêm maior legitimidade democrática.

No tocante ao legislador ordinário, é evidente que deverá observar as diretrizes estabelecidas no grau legislativo superior - a Constituição -, como aliás sói acontecer em qualquer ramo do direito. Não goza ele, portanto, de liberdade total para definir uma atividade como serviço público. $^{427}$

Sendo assim, o legislador deve atentar para as atividades que já foram qualificadas pela Constituição como serviço público, bem como para as restrições constantes da Lei

\footnotetext{
${ }^{423}$ JÈZE, 1949, v. 2, p. 19.

${ }^{424}$ Ibid., p. 22-24.

${ }^{425}$ Ibid., p. 19-20.

${ }^{426}$ GROTTI, op. cit., p. 101.

${ }^{427}$ MELLO, 2006, p. 607-610.
} 
Fundamental quanto às possibilidades de intervenção do Estado no domínio econômico, que apenas se pode dar em caráter excepcional. ${ }^{428}$

Autores há, no entanto, que entendem existirem serviços públicos e atividades as quais, ao revés, não podem ser catalogadas como tais por essência, cuja definição independe e se sobrepõe à vontade do legislador. ${ }^{429}$ Tal corrente, dita "essencialista", geralmente apóia-se na lição de Ruy Cirne Lima, para quem serviço público é

todo serviço existencial, relativamente à sociedade, ou, pelo menos,
assim havido num momento dado, que, por isso mesmo, tem de ser
prestado aos componentes daquela, direta ou indiretamente, pelo Estado
ou outra pessoa administrativa. ${ }^{430}$

Nota-se do conceito enunciado que o serviço público pode ser "havido" como existencial, relativamente à sociedade, "num momento dado". Ora, se interpretarmos que é o legislador quem pode tomar o serviço por existencial ou não, a idéia não difere das que viemos de expor. Não obstante, caso se entenda ser o próprio jurista quem pode considerar o serviço como existencial ou não, inclusive para impugnar eventual definição legal, a noção transcrita seria criticável, pois significaria avalizar a interpretação do direito posto a partir da doutrina, o que se nos afigura inaceitável.

\subsubsection{Titularidade e exercício das competências constitucionais}

${ }^{428}$ GROTTI, 2003, p. 102.

${ }^{429}$ Cf., por exemplo, ROCHA, Cármen Lúcia Antunes. Estudo sobre concessão e permissão de serviço público no direito brasileiro, p. 20-21, apud GROTTI, 2003, p. 103-104; FREITAS, Juarez. O Estado essencial e o regime das concessões e permissões de serviços públicos, In: FREITAS, Juarez, Estudos de direito administrativo, 1997, p. 33, apud GROTTI, 2003, p. 104.

${ }^{430}$ LIMA, Ruy Cirne. Princípios de direito administrativo brasileiro. 3. ed. Porto Alegre: Livraria Sulina, 1954. p. 82 . 
Os consórcios públicos, para se desincumbir da prestação associada dos serviços públicos eleitos como seu objeto, recebem competências dos entes federativos que o compõem. Estes só poderão delegar as competências privativas, e não as exclusivas. ${ }^{431}$

Em seu artigo sobre consórcios públicos, Floriano Azevedo Marques Neto analisa a delegação de funções entre os entes federados, que deve, segundo ele, respeitar certos limites, e defende especificamente a possibilidade de um ente da Federação titular de um serviço público transferir a competência material para organizá-lo e prestá-lo, inclusive a um consórcio público. ${ }^{432}$ Com efeito, as diretrizes constitucionais e legais a respeito não deixam dúvidas quanto a essa possibilidade.

A questão se torna mais complexa quando se enfoca o transpasse de competências materiais, pessoal e bens para um consórcio constituído sob a forma de pessoa jurídica de direito privado. Ainda assim, tendo em vista a enorme quantidade de restrições apostas ao regime jurídico dessas entidades, que se torna praticamente publicístico, impondo, v.g., inúmeras cautelas para com o patrimônio público, não nos parece haver incompatibilidade nas aludidas transferências.

Deve-se observar que, quando o repasse de competências se opera por meio de contrato de programa, não pode ser transferido ao contratado o exercício dos poderes de planejamento, regulação e fiscalização dos serviços a serem prestados, a teor do art. 13 , § 3. ${ }^{\circ}$, da Lei. Isso porque tais prerrogativas expressam "verdadeiros poderes de direção, que não comportam renúncia pelo ente titular do serviço". ${ }^{433}$

Ora, ainda que a lei não o previsse expressamente, é certo que qualquer transferência de competências constitucionais ou legais (seja através de delegação, seja por meio de contratação) não pode ser total, devendo sempre remanescer um mínimo de atribuições, consubstanciadas num "poder de direção" sobre o exercício da atividade transferida. Caso contrário, de nada valeriam as previsões constitucionais e legais de competências.

\footnotetext{
${ }^{431}$ Cf. item 2.2 supra.

${ }^{432}$ MARQUES NETO, 2005a.

${ }^{433}$ CARVALHO FILHO, 2009, p. 153.
} 
Aliás, como observado por Odete Medauar e Gustavo Justino de Oliveira, permitir a transferência, via contrato de programa, dos poderes de planejamento, regulação e fiscalização do serviço contratado significaria descaracterizar o ajuste, eliminando a própria gestão associada. ${ }^{434}$

Dessa forma, seria válido afirmar que, mesmo quando não se tratar de contrato de programa, os entes associados que transferem competências a um consórcio público, nos termos do art. 241 da Constituição, permanecem com determinadas atribuições que são indelegáveis, porque inerentes a sua autonomia federativa. Nesse sentido, merece interpretação restritiva o mencionado dispositivo constitucional, que possibilita unicamente a transferência de "encargos, serviços, pessoal e bens essenciais à continuidade dos serviços transferidos".

\subsubsection{Possíveis objetivos dos consórcios}

O elenco de possíveis objetivos do consórcio, que figurava de modo exaustivo no Projeto de Lei n. ${ }^{\circ} 3.884 / 04$, restou suprimido no texto final, deixando-se aos próprios entes que se associam a especificação do conteúdo do consórcio (art. 2. ${ }^{\circ}$, caput), respeitada a idéia de "gestão associada de serviços públicos".

Deve-se chamar a atenção, neste passo, para a necessidade de se interpretar o rol de possíveis objetos dos consórcios dado pelo Decreto n. ${ }^{\circ}$ 6.017/07 de modo conforme à Constituição Federal, que fala apenas em serviços públicos. ${ }^{435}$

A idéia central presente nos consórcios públicos costuma ser a de viabilizar a gestão pública nos espaços metropolitanos, nos quais a solução de problemas comuns só se pode obter por meio de políticas e ações conjuntas. Nesse sentido, os consórcios representam uma grande vantagem, permitindo que pequenos Municípios ajam em parceria e, em decorrência do ganho de escala, melhorem sua capacidade técnica, gerencial e financeira. De outro lado, o consorciamento justifica-se também em virtude da existência

\footnotetext{
${ }^{434}$ MEDAUAR; OLIVEIRA, 2006, p. 108.

${ }^{435}$ HARGER, 2007, p. 102.
} 
de regiões de interesse comum, delineadas por contingências naturais, como as bacias hidrográficas, ou artificiais, como os pólos regionais de desenvolvimento, nas quais se faz indispensável a gestão de serviços públicos de forma integrada.

Mas a acurada delimitação dos possíveis objetos dos consórcios públicos passa necessariamente pela exegese do conceito jurídico indeterminado de "gestão associada de serviços públicos" constante do art. 241 da Constituição Federal.

A leitura atenta do dispositivo permite concluir que os consórcios públicos só podem prever: (i) a gestão associada de serviços públicos; e (ii) a transferência de encargos, serviços, pessoal e bens essenciais à continuidade dos serviços transferidos. Como já exposto, o consórcio sempre envolverá serviços públicos, cuja acepção já foi objeto de exame. ${ }^{436}$ Note-se, de outra parte, que o exercício da competência de transferir encargos, serviços, pessoal e bens pressupõe que haja gestão associada de serviços públicos, uma vez que se condicionam tais transferências à sua essencialidade para a "continuidade dos serviços".

Importa indagar, a propósito, se a gestão associada autorizada pela Constituição alcançaria as "atividades-meio" da prestação de serviços públicos. A questão remete ao conceito de serviço público com que se trabalhe. Segundo Odete Medauar, tais atividades não se incluiriam na acepção técnica de serviço público. ${ }^{437}$

No entanto, o sentido de serviço público empregado pelos legisladores constituinte e ordinário para conformar os consórcios parece mais amplo que essa acepção técnica. $\mathrm{Na}$ verdade, se a intenção foi viabilizar a cooperação interfederativa por meio da gestão associada de serviços públicos, não faria muito sentido deixar de fora da atuação consorciada aquelas atividades que, embora não se qualifiquem, sob uma perspectiva mais restrita, como serviços públicos, revelam-se essenciais para a consecução dos objetivos do consórcio. Sob esse ângulo, seria possível defender que, ainda que o consórcio tivesse por objeto apenas atividades consideradas como "meios" para a prestação de serviços públicos, o que importa é que a entidade está servindo à missão para a qual foi concebida.

\footnotetext{
${ }^{436}$ Cf. item 8.2.1 supra.

${ }^{437}$ MEDAUAR, 2001, p. 369.
} 
Atualmente, as principais áreas de atuação dos consórcios são a prestação de serviços de saúde, envolvendo inclusive a construção e administração de hospitais, e a gestão do tratamento de lixo, água e esgoto da região consorciada. ${ }^{438}$

Dentre as possíveis atividades do consórcio público, avulta também a de realizar licitação em favor dos entes consorciados, expressa na alteração processada no art. 112 da Lei n. ${ }^{\circ}$ 8.666/93 por conta do art. 17 da Lei de Consórcios, que acrescentou àquele dispositivo outro parágrafo. Com efeito, pela nova norma inserida, os consórcios “poderão realizar licitação da qual, nos termos do edital, decorram contratos administrativos celebrados por órgãos ou entidades dos entes da Federação consorciados”. O art. 112 cuida dos casos em que o objeto do contrato em vista interessa a mais de uma entidade pública. Nesses casos, portanto, a licitação pode ser realizada pelo próprio consórcio, ainda que o contrato que dela decorra venha a ser celebrado pelo ente consorciado, e não pelo consórcio.

Deve-se interpretar o parágrafo acrescentado em harmonia com o caput do artigo em comento (112 da Lei n. ${ }^{\circ}$ 8.666/93), que trata de hipótese na qual uma entidade pública se encarrega de realizar licitação referente a futuro contrato que seja de interesse não só da entidade que realiza o certame, mas também de outras. Tal possibilidade significa sobretudo uma economia de recursos, evitando-se a realização de diversas licitações paralelas com o mesmo objeto. Ora, no $\S 1 .^{\circ}$ permite-se que um consórcio público assuma a realização do procedimento, de modo que o vencedor da licitação possa contratar com os órgãos ou entidades dos entes políticos consorciados, desde que tenha havido expressa previsão no edital.

Na verdade, tal permissão nem precisaria ter sido expressamente consignada. Como visto, os objetivos dos consórcios são relativamente amplos, abrangendo toda atividade ligada à gestão associada de serviços públicos, restando implícita, assim, a atividade de organização de certame licitatório visando à celebração de contratos administrativos, desde que estes se encontrem vinculados à sobredita gestão associada.

A propósito do tema, vale ainda citar o ensinamento de José dos Santos Carvalho Filho, para quem

${ }^{438}$ Cf. Capítulo 11 infra. 
a idéia de licitação compartilhada é de fácil percepção. Partindo-se da premissa de que o consórcio é constituído por entes federativos e, ainda, do fato de que o ente consorcial pode prestar serviços para seus próprios componentes, torna-se realmente mais célere e eficaz que, em determinadas hipóteses, uma só licitação seja realizada dando ensejo a várias contratações. ${ }^{439}$

A hipótese pressupõe, evidentemente, que os entes consorciados preferiram não transferir ao consórcio a própria celebração do contrato, o que se mostraria igualmente possível sempre que o objeto do contrato figurasse entre as atribuições do consórcio, e fosse consentâneo com seu gizamento constitucional e legal.

A partir de tais considerações, pode-se vislumbrar duas distintas formas de atuação dos consórcios quanto à contratação em favor de seus partícipes: em uma delas, o consórcio limita-se a conduzir um procedimento licitatório (por exemplo, para compra de material de escritório) até a proclamação do vencedor, que poderá contratar com cada um dos entes consorciados; na outra, o consórcio recebe de seus partícipes poderes para realizar a licitação, celebrar um contrato com o vencedor e fiscalizar seu cumprimento, procedendo, ao final, à liquidação e ao pagamento (naquele mesmo exemplo, o consórcio, após o certame, celebraria o contrato, assegurando-se de que os quantitativos fossem devidamente entregues a cada ente consorciado no prazo ajustado e conforme as especificações do edital e realizando, enfim, o pagamento, com seus próprios recursos).

Nessa última hipótese, pressupõe-se, logicamente, que a contratação esteja prevista no estatuto do consórcio, bem assim que os entes tenham, por meio de contrato de rateio, entregue ao consórcio as verbas necessárias para a contratação, proporcionalmente aos quantitativos pretendidos, e, finalmente, que sejam respeitadas as normas da Lei n. ${ }^{\circ}$ 8.666/93, de molde a não se prejudicar a competição entre os possíveis fornecedores, nem tampouco a seleção da proposta mais vantajosa à Administração de cada ente.

${ }^{439}$ CARVALHO FILHO, 2009, p. 167. 


\section{$\underline{\text { 8.3. Formas de prestação de serviço público }}$}

Ante a previsão do art. 241 da Constituição e o estatuto jurídico delineado na Lei n. ${ }^{\circ} 11.107 / 05$, permite-se aos entes federativos delegar ao consórcio público de que façam parte a atribuição de prestar serviços públicos. Os consórcios, por sua vez, poderão prestar os serviços públicos a si atribuídos de forma direta ou indireta.

\subsubsection{Execução direta}

Mesmo que o contrato de consórcio contenha autorização para que a entidade consorcial delegue a execução de serviços públicos a terceiros, ela poderá, se seus representantes entenderem mais conveniente, executá-los diretamente, ${ }^{440}$ inclusive lançando mão da prerrogativa de arrecadar tarifas e outros preços públicos $\left(\operatorname{art} .2^{\circ}, \S 2^{\circ}\right.$, da Lei n. $\left.{ }^{\circ} 11.107 / 05\right)$.

Para que o consórcio preste um serviço diretamente, é mister que tal serviço seja "objeto finalístico do referido consórcio", cabendo aos entes consorciados "lhe transferirem, por força de lei, recursos humanos e materiais para a consecução de tais fins". 441

\subsubsection{Execução indireta}

Dispõe o art. 2. ${ }^{\circ}$, $3 .^{\circ}$, da Lei n. ${ }^{\circ} 11.107 / 05$ :

$\S 3^{\circ}$. Os consórcios públicos poderão outorgar concessão, permissão ou autorização de obras ou serviços públicos mediante autorização prevista

${ }^{440}$ CANÇADO, Maria de Lourdes Flecha de Lima Xavier. Serviço público no âmbito dos consórcios públicos. In: PIRES, Maria Coeli Simões; BARBOSA, Maria Elisa Braz (Coord.). Consórcios públicos: instrumento do federalismo cooperativo. Belo Horizonte: Fórum, 2008. p. 250-251.

${ }^{441}$ ALVES, 2006, p. 77. 
no contrato de consórcio público, que deverá indicar de forma específica o objeto da concessão, permissão ou autorização e as condições a que deverá atender, observada a legislação de normas gerais em vigor.

A legislação de normas gerais a que se refere o dispositivo tem como marco a Lei n. ${ }^{\circ}$ 8.987/95 (Lei de Concessões), que estabelece, em obediência ao art. 175 da Constituição Federal, a obrigatoriedade de licitação precedendo a concessão ou permissão de serviço público.

$\mathrm{O}$ art. $4 .^{\circ}$ da Lei n. ${ }^{\circ} 11.107 / 05$, ao estabelecer as cláusulas indispensáveis do protocolo de intenções que deve preceder a formação de um consórcio público, inclui entre elas, no inciso XI, a de autorização para a gestão associada de serviços públicos, explicitando as competências cujo exercício se transferiu ao consórcio público, os serviços públicos objeto da gestão associada e a área em que serão prestados e a autorização para licitar ou outorgar concessão, permissão ou autorização da prestação dos serviços.

Portanto, verifica-se que os consórcios poderão prestar os serviços a eles delegados diretamente, transferi-los (por concessão, permissão ou autorização, sempre precedidas de licitação) para particulares ou delegá-los a entidades ou órgãos de um dos entes da Federação consorciados, desde que essa possibilidade se encontre prevista no contrato de consórcio, nesse caso por meio do contrato de programa. ${ }^{442}$

Isso significa que ambas as modalidades de consórcio - de direito público e privado - podem se valer das cláusulas exorbitantes para celebrar típicos contratos administrativos, que são os contratos de concessão.

Como nos lembra Vladimir Alves, "os contratos da Administração Pública se caracterizam como administrativos ou não em razão do seu conteúdo, e não da qualidade da pessoa que o celebra". ${ }^{443}$ Vale dizer, toda vez que pactuarem contrato de concessão de uso de bem público, por exemplo, os consórcios públicos estarão celebrando um verdadeiro contrato administrativo, independentemente da natureza jurídica do concedente,

\footnotetext{
${ }^{442}$ Cf. item 8.7.2 infra.

${ }^{443}$ ALVES, 2006, p. 56.
} 
uma vez que "estarão lançando mão da transferência de recursos públicos através de rateios ou repasses de contribuições ou subvenções". ${ }^{444}$

Da mesma forma, pode o consórcio celebrar parceria público-privada, que não deixa de configurar um contrato de concessão, seja na modalidade administrativa, seja na modalidade patrocinada.

Para Marcelo Harger, que diverge de Odete Medauar e Gustavo Justino de Oliveira, ${ }^{445}$ também os consórcios dotados de personalidade jurídica de direito privado podem celebrar PPPs, dada a abrangência do parágrafo único do art. $1 .^{\circ}$ da Lei n. ${ }^{\circ}$ 11.079/04. ${ }^{446}$ José dos Santos Carvalho Filho acompanha o entendimento, que julga mais adequado ao fato de os consórcios instituídos como pessoa de direito privado integrarem necessariamente a administração indireta dos entes federativos. ${ }^{447}$ De todo modo, se a própria lei dá aos consórcios, sem distinguir sua natureza, o direito de realizarem "concessões", não se pode restringir o termo para excluir as concessões patrocinadas e administrativas.

Por outro lado, ao falar em autorização para "licitar ou outorgar" concessão, permissão ou autorização da prestação dos serviços, a lei acaba por abrir margem à exegese no sentido de que o administrador do consórcio, caso decida por delegar a terceiro a prestação do serviço em questão, poderia fazê-lo sem licitação, desde que no protocolo de intenções constasse a autorização não para licitar, mas para "outorgar" concessão, permissão ou autorização da prestação de serviços públicos. No entanto, tal exegese deve ser deixada de lado, para que não se infrinja o art. 175 da Constituição Federal. A hipótese de outorga deve servir somente às autorizações, entendidas estas como institutos de transferência precária de direitos, incompatíveis com a formalidade da licitação.

\section{$\underline{\text { 8.4. Bens do consórcio }}$}

\footnotetext{
${ }^{444}$ ALVES, 2006, p. 56.

${ }^{445}$ HARGER, 2007, p. 37-38.

${ }^{446}$ Ibid., p. 104.

${ }^{447}$ CARVALHO FILHO, 2009, p. 54-55.
} 
A principal vantagem de se conferir personalidade jurídica aos consórcios talvez seja a possibilidade, que só assim existe, de se atribuírem à entidade direitos e obrigações, vale dizer, de se conceder ao consórcio um patrimônio.

Entre outras coisas, é dado ao consórcio acumular bens, entendidos em sentido amplo como os materiais e equipamentos direta ou indiretamente necessários aos seus objetivos prestacionais. Sob essa ótica, todos os bens pertencentes aos consórcios, tenham estes estrutura de direito público ou de direito privado, são bens públicos, afetados que estão à prestação de serviços públicos. A propósito, o próprio art. 241 da Constituição federal já sinaliza de antemão que a entidade consorcial receberá os bens "essenciais à continuidade dos serviços transferidos". 448

Tais bens podem ser adquiridos pelo consórcio ou havidos mediante doação ou cessão dos entes consorciados, realizadas quando da celebração do contrato de consórcio ou em momento posterior, por instrumento próprio.

\subsubsection{Transferência de bens}

A Lei n. ${ }^{\circ}$ 11.107/05 também estabelece que os entes consorciados poderão doar, destinar ou ceder ao consórcio o uso de bens móveis ou imóveis (art. $4^{\circ}, \S^{\circ} 3^{\circ}$ ). A previsão é essencial à persecução dos objetivos do consórcio e se harmoniza com a personalização da figura consorcial. Em se tratando de sujeito de direitos e obrigações, é natural que o consórcio detenha um patrimônio constituído por cessões e doações dos partícipes, patrimônio esse sobre o qual apóia sua estrutura administrativa voltada à gestão associada de serviços públicos.

A alienação de bens públicos aos consórcios não pressupõe sua prévia desafetação, uma vez que, tais como os dominicais, os bens de uso comum e de uso especial não se encontram alijados do mercado público, mas apenas do comércio privado. ${ }^{449}$

448 BARBOSA, Maria Elisa Braz. Os bens nos consórcios públicos. In: PIRES, Maria Coeli Simões; BARBOSA, Maria Elisa Braz (coord.). Consórcios públicos: instrumento do federalismo cooperativo. Belo Horizonte: Fórum, 2008, p. 226-227.

${ }^{449}$ BARBOSA, 2008, p. 217. Cf. DI PIETRO, Maria Sylvia Zanella. 2005b, p. 592. 
Se a destinação de bens ao consórcio se realizar por intermédio de contrato de programa, este deverá identificar os bens "que terão apenas a sua gestão e administração transferidas e o preço dos que sejam efetivamente alienados ao contratado" (art. 13, $\S 2^{\circ}$, V, da Lei de Consórcios Públicos).

Os bens transferidos ao consórcio, em princípio, não são objeto de reversão ou retrocessão ao patrimônio do ente federado que se retira da avença, salvo quando houver expressa previsão em contrário no contrato de consórcio ou no instrumento pelo qual se formalizou a transferência ou alienação (art. 11, $\S 1^{\circ}$, da lei). Homenageia-se com isso o princípio da continuidade do serviço público, evitando-se que a retirada de um ente federativo ponha em risco a prestação do serviço.

Quando o consórcio se extingue, os bens retornam "aos titulares do respectivo serviço" (art. 12, $\S 1^{\circ}$ ). Se existirem vários titulares do mesmo serviço público (por exemplo, num consórcio intermunicipal), deve-se extrair dessa norma que o bem retorna ao seu antigo proprietário.

\subsubsection{Desapropriação}

Para se desincumbir de suas tarefas relacionadas à prestação de serviços públicos, os consórcios com personalidade de direito público podem promover desapropriações e instituir servidões (art. $2^{\circ}$, II, da Lei de Consórcios).

Marcelo Harger defende que, embora o art. 2. ${ }^{\circ}, \S 1 .^{\circ}$, II, da Lei n. ${ }^{\circ} 11.107 / 05$, pareça restringir a possibilidade ao "consórcio de direito público", também os de direito privado podem promover desapropriações e instituir servidões, pela interpretação do dispositivo no contexto (artigo e parágrafo) em que se insere, e conjugado com a lei de desapropriações (Decreto-lei n. $\left.{ }^{\circ} 3.365 / 41\right){ }^{450}$

Com a devida vênia ao entendimento do autor, não nos parece que se possa proceder a tal interpretação conjunta com a lei de desapropriações quando se tem norma superveniente literal (art. $2^{\circ}, \S 1^{\circ}$, II, da Lei de Consórcios Públicos) no sentido de atribuir

${ }^{450}$ HARGER, 2007, p. 106-107. 
a possibilidade de promover desapropriações e instituir servidões somente aos consórcios de direito público, ausente tal previsão quanto aos consórcios criados sob as leis civis. Assim sendo, tem-se que eventual incoerência dessa opção legislativa em relação a outras normas de nosso ordenamento não tira dela sua eficácia - em outras palavras, pode-se discutir a inconveniência ou impropriedade da escolha do legislador, mas não sua validade jurídica.

Quanto aos aspectos procedimentais da desapropriação, tem-se que a autoridade competente para expedir a declaração de utilidade ou necessidade pública ou interesse social, no caso de consórcio entre entes de mesmo nível federativo, é o Chefe do Executivo do ente onde se situa o bem. Em se tratando de entes de diferentes níveis, o protocolo de intenções deve disciplinar qual o ente que realizará a desapropriação e pagará a justa indenização ao proprietário do imóvel. ${ }^{451}$

\subsection{Regime jurídico}

Conforme se pôde verificar em diversas passagens, o consórcio público, na sua configuração atual, é objeto de um confuso regime jurídico que oscila entre a disciplina publicista e a normativa reservada aos particulares. Em conclusão ao que foi até aqui exposto, bastaria ressaltar que a regra, no consórcio público, como o próprio nome diz, é o regime de direito público. Este incide plenamente no caso das associações públicas, embora o art. 15 da lei pareça sugerir o contrário.

Como é de todo sabido, o regime de direito público conta com regras especiais, exorbitantes do direito comum, que se justificam basicamente porque o interesse particular deve ceder ante o interesse geral. ${ }^{452}$ Tal consideração serve tanto para explicar as prerrogativas como as sujeições a que se submete a pessoa jurídica regida pelo direito público.

\footnotetext{
${ }^{451}$ Ibid., p. 108.

${ }^{452}$ JÈZE, 1949, v. 2, p. 5.
} 
Por outro lado, é igualmente sabido que a Administração, para fazer funcionar um serviço público, nem sempre é obrigada a adotar procedimentos de direito público. ${ }^{453}$ Assim é que se abre a ela mais uma vez, por meio dos consórcios públicos com personalidade jurídica de direito privado, a possibilidade de utilização do regime privado para a consecução de fins públicos.

No entanto, como vimos, os consórcios constituídos sob a forma de associação civil sofrem tamanho influxo de normas de ordem pública que mal podem ser considerados entidades sujeitas ao regime privado.

\subsection{Estrutura interna}

A legislação concede grande liberdade para os entes consorciados se organizarem internamente.

Nesse sentido, importante papel exercem os estatutos consorciais previstos no art. $8^{\circ}$ do Decreto Federal n. ${ }^{\circ}$ 6.017/07, os quais, desde que não infrinjam as disposições constantes do contrato de consórcio, poderão disciplinar a estrutura dos consórcios, prevendo o funcionamento de quaisquer órgãos entendidos convenientes.

O único desses órgãos que precisa obrigatoriamente ser criado é a assembléia geral, composta pelos próprios entes federados, que é a instância decisória máxima da entidade (art. $4 .^{\circ}$, VII, da Lei n. $\left.{ }^{\circ} 11.107 / 05\right)$. A assembléia geral é integrada por todos os entes federativos consorciados, que podem, entretanto, fazer jus a número diferente de votos nas deliberações $\left(\operatorname{art.} 4^{\circ}, \S 2^{\circ}\right)$.

Seria recomendável que o consórcio fosse composto também por um Conselho Fiscal ou órgão similar, a bem da higidez de suas contas e, conseqüentemente, do patrimônio público.

No mais, em atenção ao princípio democrático e participativo, afigura-se importante a previsão de representação popular nos órgãos consorciais, ou mesmo a criação de órgãos específicos que permitam o permanente diálogo com a sociedade civil,

\footnotetext{
${ }^{453}$ Ibid., p. 6.
} 
como um conselho integrado por cidadãos eleitos, ou representantes de entidades civis ligadas aos assuntos objeto do consórcio.

\section{$\underline{\text { 8.7. Recursos }}$}

Para a consecução de seus objetivos, o consórcio precisa, evidentemente, captar recursos, o que pode ocorrer das seguintes maneiras: repasse de verbas orçamentárias dos entes consorciados, por meio de contrato de rateio; cobrança de tarifa ou preço público pela prestação de serviços públicos; cobrança pelo uso ou outorga de uso de bens públicos que administra, ou de bens públicos administrados por ente consorciado, mediante autorização deste; repasse de verbas provenientes de convênios com outros entes; operações de crédito.

Por ser desprovido do poder de tributar, que é competência indelegável dos entes políticos, o consórcio não pode instituir taxas.

\subsubsection{Contrato de rateio}

Pelo contrato de rateio (art. $8^{\circ}$ da Lei n. $^{\circ} 11.107 / 05$ ), os entes federados integrantes do consórcio público repassam recursos oriundos de seus orçamentos para a entidade consorcial.

José dos Santos Carvalho Filho define o contrato de rateio como "o ajuste pelo qual os entes consorciados firmam relação jurídica no sentido de definir suas obrigações econômico-financeiras para com o consórcio público [...]". 454

Cada ente consorciado celebra esse ajuste com o consórcio, prevendo as verbas a serem entregues ao ente associativo, verbas essas que deverão ser devidamente incluídas no orçamento do partícipe.

${ }^{454}$ CARVALHO FILHO, 2009, p. 97. 
Trata-se de contrato bilateral e sinalagmático, no qual uma das partes visa a usufruir da participação no consórcio e a outra busca a vantagem financeira que lhe permitirá fornecer os serviços objeto do consórcio. ${ }^{455}$

A celebração de contrato de rateio, por sua própria natureza, prescinde de licitação, uma vez que só pode acontecer entre pessoas específicas - os partícipes do consórcio -, traduzindo assim hipótese de inexigibilidade (art. 25 da Lei n. ${ }^{\circ}$ 8.666/93).

Na prática, freqüentemente o contrato de rateio poderá ter vigência maior que a da dotação orçamentária que o suporta, já que é presumível que os programas e ações objeto do contrato ultrapassem um exercício financeiro e, portanto, constem do plano plurianual (art. 167, § 1. ${ }^{\circ}$, da Constituição Federal).

Dispõe o art. $8 .^{\circ}, \S 5 .^{\circ}$, da Lei $.^{\circ} 11.107 / 05$ :

$\S 5^{\circ}$. Poderá ser excluído do consórcio público, após prévia suspensão, o ente consorciado que não consignar, em sua lei orçamentária ou em créditos adicionais, as dotações suficientes para suportar as despesas assumidas por meio de contrato de rateio.

No entanto, deve-se atentar para a hipótese em que a suspensão ou exclusão seria mais prejudicial ao consórcio que a própria permanência do ente. Como exemplo, figure-se um consórcio composto por dois entes. Se um deles não prevê recursos para cumprir o contrato de rateio, tem-se que, em tese, deveria ser suspenso - mas isso inviabilizaria o consórcio. Caberia aqui perquirir a mens legis por trás dessa previsão de suspensão ou exclusão, que parece ser dúplice: por um lado, afasta-se o ente para não prejudicar ainda mais o consórcio; por outro, o afastamento se dá para garantir a obediência à responsabilidade fiscal. Considerada a primeira finalidade da norma, não faria sentido suspender o ente faltoso, o que acarretaria maiores problemas ao consórcio. A segunda finalidade, no entanto, mostra-se indisponível aos entes consorciados. Daí a justificativa para a penalidade, ainda que prejudique o consórcio.

${ }^{455}$ Ibid., p. 98-99. 


\subsubsection{Outras fontes}

O consórcio poderá auferir renda, ainda, a partir da remuneração pelo usuário do serviço público, quando optar pela prestação direta do serviço. Além disso, a Lei n. ${ }^{\circ}$ 11.107/05 cometeu aos consórcios públicos a prerrogativa de emitir documentos de cobrança e de exercer atividades de arrecadação de tarifas e de outros preços públicos pelo uso ou outorga de uso de bem público por eles administrado.

A entidade associativa pode também receber auxílios, subsídios e subvenções, ${ }^{456}$ assim como contratar operações de crédito, as quais se sujeitam aos limites estabelecidos no art. 52, VII, da Constituição da República, conforme estabelece - ou melhor dizendo, apenas enfatiza, já que a norma constitucional é inafastável - o parágrafo único do art. 10 do Decreto Federal n. ${ }^{\circ}$ 6.017/07.

\subsection{Pessoal}

O número de empregados do consórcio, bem assim as formas de provimento e sua remuneração, devem constar do protocolo de intenções (art. $4 .^{\circ}$, IX, da Lei de Consórcios). É de se prever a dificuldade que os signatários do protocolo terão para projetar, com exatidão, a quantidade de servidores necessários para o bom andamento dos trabalhos do consórcio, sem correrem o risco de se equivocar nos cálculos, sobrecarregando os funcionários ou desperdiçando dinheiro público.

Também a previsão da remuneração terá de ser objeto de cuidadoso estudo, e quiçá prévia consulta ao Legislativo, uma vez que representa criação de despesa corrente que deve ser acordada sem ressalvas por todos os partícipes do ajuste, sob pena de provocar desequilíbrio no custeio do consórcio.

${ }^{456}$ Sobre o tema, cf. detalhada análise de Odete Medauar e Gustavo Justino de Oliveira, op. cit., p. 38-43. 
A criação, transformação e extinção de cargos, empregos e funções públicas, como se sabe, é matéria afeta, de regra, à lei (art. 48, X, da Constituição Federal). Assim é que a ratificação, por lei, do protocolo de intenções é o instrumento hábil a criar os empregos públicos do consórcio. No entanto, considerando-se que cada ente compromissado promulga sua própria lei confirmando o protocolo de intenções e, com isso, aderindo ao consórcio, caberia questionar qual das leis representaria a efetiva criação jurídica de tais empregos.

A solução mais adequada parece ser a de que os empregos são criados quando do surgimento da personalidade jurídica do consórcio, ou seja, por ocasião da ratificação da última lei ou da ratificação da lei a partir da qual o protocolo de intenções determinasse a criação da pessoa jurídica. Isso porque, da mesma forma que a pessoa jurídica precisa ganhar existência simultânea para todos os entes consorciados, também os empregos públicos - e, ademais, tudo o que disser respeito à estrutura e ao funcionamento do consórcio - precisam surgir ao mesmo tempo, pois são os mesmos empregos sob ponto de vista de todos os consorciados.

De outra parte, assinale-se que toda modificação jurídica a ser operada quanto aos empregos públicos do consórcio, incluindo a alteração da remuneração, deve passar pelo crivo da assembléia geral e ser ratificada por lei de cada um dos entes consorciados para produzir efeitos (art. 12 da Lei n. $\left.{ }^{\circ} 11.107 / 05\right)$.

De forma similar sucede com as normas sobre contratação temporária sem concurso (art. 37, IX, da Constituição), que devem estar previstas no protocolo de intenções, a ser aprovado por lei de cada ente consorciado.

A Lei n. ${ }^{\circ} 11.107 / 05$ dispõe, em seu art. $6 .^{\circ}, \S 2 .^{\circ}$, que os funcionários dos consórcios criados como associações civis são regidos pela Consolidação das Leis do Trabalho (CLT). Tais agentes, assim como os pertencentes a consórcios com natureza de associação pública, devem ser considerados empregados públicos da administração indireta, só podendo ser investidos no emprego mediante prévia aprovação em concurso público, ex vi do art. 37, II, da Lei Maior e do próprio art. $6 .^{\circ}, \S 2 .^{\circ}$, da Lei de Consórcios Públicos.

Expressiva ainda é a possibilidade, já assegurada no art. 241 da Constituição, e reforçada pelo art. $4^{\circ}, \S 4^{\circ}$, da Lei n. $.^{\circ} 11.107 / 05$, de os entes consorciados cederem seus 
servidores ao consórcio público, ou, ainda, de entes conveniados com os partícipes (e não conveniados com o consórcio, como se extrai da redação do parágrafo em testilha) fazerem o mesmo. Para tanto, exige-se a formalização de contrato de programa, a teor do art. 13 da Lei n. ${ }^{\circ} 11.107 / 05$, o qual estabelecerá, dentre outras especificidades, o responsável por arcar com os ônus e os passivos do pessoal transferido (art. 13, § $2^{\circ}$, IV).

Conquanto a Constituição e outros dispositivos da Lei de Consórcios (como o art. 13) façam menção à transferência de servidores, deve-se observar que, nesses casos, não há que se falar propriamente em transferência, mas em cessão temporária, a qual deve atender também ao disposto nos estatutos das entidades cedentes. ${ }^{457}$

Em acréscimo a tudo quanto se disse, caberia assinalar a previsão do art. $8^{\circ}, \S 2^{\circ}$, do Decreto Federal n. ${ }^{\circ}$ 6.017/07, no sentido de que os estatutos do consórcio podem "dispor sobre o exercício do poder disciplinar e regulamentar, as atribuições administrativas, hierarquia, avaliação de eficiência, lotação, jornada de trabalho e denominação dos cargos". Referindo-se aos empregados públicos, a regra só pode ser interpretada de maneira que se compatibilize com o regime celetista, que é próprio da definição de emprego público. Doutra forma teríamos literalmente um regime estatutário onde o legislador impôs a observância da CLT.

Como já foi ressaltado, os funcionários do consórcio instituído com personalidade jurídica de direito privado são celetistas (art. 6. $.^{\circ} \S 2 .^{\circ}$, da Lei n. ${ }^{\circ} 11.107 / 05$ ). A lei, conquanto não seja expressa a respeito, parece estender o mesmo regime ao pessoal das associações públicas, na medida em que se refere, no art. $4 .^{\circ}$, IX - que trata de uma das cláusulas necessárias dos protocolos de intenções -, a “empregados públicos”. Edimur Ferreira de Faria fala apenas em servidores estatutários, no caso dos consórcios com personalidade jurídica de direito público. ${ }^{458}$

Atualmente, o Poder Público não pode contratar servidores em regime celetista para preencher vagas na administração direta, autárquica ou fundacional. É que a decisão cautelar do Supremo Tribunal Federal na Ação Direta de Inconstitucionalidade n. 2.135 restabeleceu o regime jurídico único dos servidores públicos da União, Estados, Distrito

\footnotetext{
${ }^{457}$ FARIA, 2007, p. 431-432.

${ }^{458}$ FARIA, 2007, p. 427.
} 
Federal e Municípios. ${ }^{459}$ Na prática, isso quer dizer que não mais se admite a convivência de regimes celetista e estatutário nessas esferas: só o último é permitido.

Destarte, as associações públicas, como autarquias que são, só podem admitir pessoal pelo regime de cargos públicos.

Independentemente da discussão sobre o regime jurídico único, que não se encontra definitivamente resolvida, e mirando-se também o caso dos consórcios de direito privado, é de se perguntar se não seria possível vislumbrar hipóteses em que o consórcio deva ter apenas servidores públicos estatutários, e não empregados. O Supremo Tribunal Federal, por um de seus Ministros, em exame cautelar, já decidiu que o regime de emprego público é incompatível com a natureza das atividades de determinados entes públicos. ${ }^{460}$

Parece razoável a tese de que certas atribuições, por envolverem a necessidade de uma atuação segura, dotada de independência funcional, não se coadunem com a falta de estabilidade de um emprego público. De todo modo, a hipótese parece mais afeta à realidade de agências reguladoras (como sucedeu na decisão citada) do que à de entidades prestadoras de serviços públicos.

\subsection{Atuação concertada}

De molde a perseguir seus objetivos, é lícito ao consórcio atuar em coordenação com outros órgãos públicos e em colaboração com particulares.

Nesse sentido, os consórcios podem, entre outras coisas, firmar contratos de gestão com Organizações Sociais e termos de parceria junto a Organizações da Sociedade Civil de Interesse Público (art. 4. ${ }^{\circ}, \mathrm{X}$, da Lei de Consórcios Públicos), ${ }^{461}$ devendo-se alertar apenas para que tais acordos não representem verdadeira burla ao regime de direito público.

\footnotetext{
${ }^{459}$ Rel. Min. Néri da Silveira, julgada em 02.08.2007. A decisão, que reconheceu vício formal no processo de votação da Emenda Constitucional n. ${ }^{\circ}$ 19/98, tem efeitos ex nunc, não afetando as situações já consolidadas e regulando o assunto até o julgamento de mérito da ação.

${ }^{460}$ Medida Cautelar na ADIn 2.310/DF, Rel. Min. Marco Aurélio, julgada ad referendum do Plenário em 19.12.2000. O referendo da cautelar foi posteriormente julgado prejudicado, por perda do objeto, em decisão monocrática do Relator Carlos Velloso, proferida em 07.12.2004.

${ }^{461}$ Cf. MEDAUAR; OLIVEIRA, 2006, p. 60-61.
} 
Para a celebração de tais ajustes, seguem-se, em princípio, as regras aplicáveis a qualquer entidade pública. Quanto à necessidade de realizar licitação, caberia registrar algumas particularidades, alinhavadas a seguir.

\subsubsection{Licitação}

As contratações celebradas pelos consórcios públicos, em regra, devem ser precedidas de licitação, ainda que seja ele pessoa jurídica de direito privado (art. 6. ${ }^{\circ}, \S 2 .^{\circ}$, da Lei).

O consórcio pode ser contratado pelos entes federativos consorciados, para prestação de determinado serviço público, sem necessidade de licitação (art. 2. ${ }^{\circ}, \S 1 .^{\circ}$, III da Lei). A hipótese se refere ao contrato de programa, a ser estudado mais adiante. ${ }^{462}$ Coerentemente com tal previsão, foi também determinada a alteração do art. 24 da Lei Federal n. ${ }^{\circ}$ 8.666/93 - que versa sobre os casos de dispensa de licitação -, criando-se o inciso XXVI, que dispensa da realização de procedimento licitatório a "celebração de contrato de programa com ente da Federação ou com entidade de sua administração indireta, para a prestação de serviços públicos de forma associada nos termos do autorizado em contrato de consórcio público ou em convênio de cooperação".

Para Marçal Justen Filho, cuida-se na verdade de inexigibilidade de licitação, já que o contrato de programa configuraria, tecnicamente, convênio, no sentido da conjugação de esforços e recursos por diferentes entes da Federação. De todo modo, para evitar dúvidas, preferiu o legislador qualificar o caso como de dispensa. ${ }^{463}$

Para Cleber Demétrio Oliveira da Silva, essa dispensa poderia significar desprestígio do princípio da seleção da proposta mais vantajosa para a administração, e também queda da qualidade do serviço, uma vez que ele não estaria sujeito a seleção através de certame licitatório. ${ }^{464}$

\footnotetext{
${ }^{462} \mathrm{Cf}$. item 8.7.2 infra.

${ }^{463}$ JUSTEN FILHO, 2005a, p. 271.

${ }^{464}$ SILVA, C. D. O., 2005 a.
} 
Todavia, às considerações do autor poder-se-ia objetar que a qualidade do serviço público é assegurada, em nosso ordenamento, por diversas disposições constitucionais e legais, e controlável por diversos mecanismos, não sendo possível atribuir-se à ausência de licitação o condão de franquear ao administrador público a contratação de um serviço de má qualidade. O que advém, sim, dessa dispensa de licitação, é uma margem de liberdade para que o administrador contrate a transferência ou assunção da prestação de determinado serviço público sem a necessidade de se prender aos estritos critérios impostos por uma licitação, podendo assim escolher a entidade pública mais adequada - e talvez a única adequada, caso em que a inexigibilidade se evidencia - para executar ou compartilhar a gestão do serviço em tela.

Na verdade, a constitucionalidade dessa nova hipótese de dispensa de licitação só pode ser debatida tendo em vista os princípios norteadores da Administração Pública, bem como a antiga discussão doutrinária acerca dos limites existentes para a atividade legislativa de estipulação de casos de dispensa de licitação. E sob esse aspecto, dificilmente seria possível afastar a nova regra, que, longe de ser aberrante, parece adequar-se ao interesse social.

Note-se que, em coerência com a inserção do inciso XXVI no rol do art. 24 da Lei de Licitações, operou-se também uma alteração no art. 26, de modo a corrigir uma antiga imperfeição na redação da norma. Com efeito, esta ainda se referia aos incisos III a XXIV do art. 24, não obstante a Lei 10.973/04 já houvesse acrescentado outro inciso ao dispositivo. Ora, não seria razoável imaginar que esses novos casos de dispensa de licitação não precisariam obedecer ao disposto no art. 26 (comunicação à autoridade superior e publicação na imprensa oficial). Assim, revelou-se mais adequada a menção a “inciso III e seguintes do art. 24”, permitindo-se ainda a aplicação da norma a hipóteses de dispensa que vierem a ser criadas, independentemente da necessidade de sua alteração. ${ }^{465}$

Além da hipótese de dispensa já tratada, a Lei n. ${ }^{\circ}$ 11.107/05 previu também, mediante a modificação dos arts. 23 e 24 da Lei n. ${ }^{\circ}$ 8.666/93, outras vantagens licitatórias de que podem usufruir os consórcios públicos.

${ }^{465}$ MEDAUAR; OLIVEIRA, 2006, p. 120. 
Por força de tais alterações, acrescentou-se o $§ 8 .^{\circ}$ ao artigo 23 da Lei de Licitações - o qual estabelece as diferentes modalidades de licitação (concorrência, tomada de preços ou convite) a serem adotadas em função do valor estimado do contrato. O novo dispositivo aumentou os limites para determinação da modalidade licitatória na contratação de compras, serviços e obras de engenharia por parte dos consórcios públicos, que passaram a ser "o dobro dos valores mencionados no caput deste artigo quando formado por até 3 entes da Federação, e o triplo, quando formado por maior número".

Os estímulos do legislador à instituição de consórcios públicos prosseguem com a alteração do parágrafo único do artigo 24 da Lei n. ${ }^{\circ}$ 8.666/93, permitindo aos consórcios dispensar a licitação quando o valor da contratação não superar $20 \%$ daquele previsto na alínea $a$ dos incisos I e II do art. 23, que é o valor máximo a permitir a utilização da modalidade "convite". Vale lembrar que os limites estabelecidos para a Administração Pública em geral são de $10 \%$. Ou seja, os patamares para dispensa de licitação em razão do valor são maiores para os consórcios públicos, em comparação com a maioria dos órgãos e entidades administrativas.

\subsubsection{Contratos de programa}

O contrato de programa foi introduzido no direito brasileiro pelo art. 13 da Lei n. ${ }^{\circ}$ $11.107 / 05$.

Nos termos da própria lei, trata-se de contrato por meio do qual se regulam

as obrigações que um ente da Federação constituir para com outro ente da Federação ou para com consórcio público no âmbito de gestão associada em que haja a prestação de serviços públicos ou a transferência total ou parcial de encargos, serviços, pessoal ou de bens necessários à continuidade dos serviços transferidos. 
Embora o instrumento possa ter encontrado inspiração nos contratos de programa franceses e nos contratos e acordos de programa italianos, ${ }^{466}$ com estes não se confunde. Com efeito, os contratos de programa franceses tinham por objeto liberar uma empresa privada da limitação de preços, desde que esta observasse o plano governamental quanto aos seus programas de produção e de investimento e sua política salarial, enquanto os acordos de programa italianos eram firmados entre a Administração central e coletividades locais objetivando "compatibilizar a atuação destas a planos nacionais ou objetivos nacionais". 467

O ajuste pode ser celebrado por entes federativos, por consórcios públicos (art. 13, caput) e também por entidades da administração indireta de entes consorciados ou conveniados, desde que previsto no instrumento de consórcio ou convênio (art. 13, § 5..$^{\circ}$ ). O contrato de programa não pressupõe necessariamente a existência de consórcio público, eis que a lei fala expressamente em "obrigações que um ente da Federação constituir para com outro ente da Federação ou para com consórcio público", ou seja, mostra-se perfeitamente possível que o contrato de programa seja celebrado para regular as obrigações constituídas entre dois entes federados, ainda que alheios a qualquer consórcio público, em função da gestão associada de serviços públicos autorizada por um convênio de cooperação - possibilidade essa que decorre do art. 241, caput, da Constituição e, implicitamente, do art. $13, \S 4 .^{\circ}$, da Lei n. ${ }^{\circ} 11.107 / 05$.

As obrigações reguladas pelo contrato de programa são aquelas "de cunho operacional, ligadas a encargos, serviços, pessoal e bens essenciais à implementação dos objetivos do consórcio firmado". ${ }^{468}$

O contrato de programa se dá quando o consórcio assume diretamente direitos e obrigações em face dos entes consorciados, como a prestação de um serviço público de interesse destes. No entanto, para Marçal Justen Filho, seria "muito mais adequado" que o contrato de programa fosse celebrado pelo consórcio com personalidade jurídica de direito privado, caso em que o instrumento seria, na verdade, imprescindível. ${ }^{469}$ Sem embargo de

\footnotetext{
${ }^{466}$ Cf. MEDAUAR; OLIVEIRA, 2006, p. 101-105.

${ }^{467}$ MEDAUAR, 2001, p. 276-277.

${ }^{468}$ CAMPOS, 2006, p. 108.

${ }^{469}$ JUSTEN FILHO, 2005b, p. 124, 132.
} 
tal opinião, conforme procuramos expor, ${ }^{470}$ temos que a gestão, por parte do consórcio, de um serviço público delegado pelos entes consorciados, já é objeto do próprio contrato de consórcio, tenha a entidade associativa personalidade de direito público ou de direito privado.

A natureza do ajuste é a de um verdadeiro contrato de direito público - ou contrato da Administração -, criador de obrigações recíprocas, ainda que seja plurilateral, conjugando interesses paralelos. ${ }^{471}$

Tal contrato se afigura, hoje, o instrumento jurídico apropriado para a transferência do exercício de competências constitucionais entre entes federativos, ou entre estes e entidades da administração indireta. Trata-se de mecanismo hábil, portanto, a substituir os contratos de concessão que costumavam ser celebrados para o mesmo fim, a exemplo daqueles habitualmente firmados entre municípios de São Paulo e a Companhia de Saneamento Básico do Estado de São Paulo (SABESP), sociedade de economia mista.

Mas quais seriam, de fato, as diferenças entre o contrato de programa e o contrato de concessão, quando celebrados entre entes públicos visando à transferência do exercício de uma competência material?

Sob uma perspectiva teórica, deve-se lembrar que o contrato de concessão pressupõe uma relação de alteridade entre as partes. O concedente, que é o ente público titular do serviço, exerce poderes de fiscalização sobre o empreendimento, fazendo jus a prerrogativas exorbitantes do direito comum, às quais se submete o concessionário - que por sua vez é, por excelência, um particular. Tal relação de subordinação tem motivos óbvios para causar alguma perplexidade quando opera entre entidades públicas, e mais ainda se o liame se forma entre entes federados, autônomos que são. Ainda assim, é a titularidade constitucionalmente outorgada de determinada competência que justifica que o concedente permaneça investido nas aludidas prerrogativas, responsável que é pelo cumprimento adequado das tarefas a ele cometidas pela Lei Maior.

${ }^{470}$ Cf. item 6.1.3.2 supra.

${ }^{471}$ Em sentido contrário, cf. CARVALHO FILHO, 2009, p. 130, para quem os contratos de programa têm a natureza de convênios. 
Como lembra José Maria Rodríguez de Santiago, não se pode negar "la existencia de relaciones contractuales de subordinación también entre Administraciones públicas”. Contudo, tais relações não podem ser consideradas normais, por dois motivos principais: aquilo que se pode contratar entre dois sujeitos públicos mediante um contrato de subordinação, muitas vezes "podría, también, com apoyo en el Derecho positivo, articularse a través de um convenio interadministrativo"; e nem sempre se poderá vislumbrar no ajuste entre duas Administrações a possibilidade de aplicação de "prerrogativas típicas de la contratación administrativa - por ejemplo, por que los bienes de cada Administración son inembargables también frente a las demás". 472

A bem da verdade, não seria despropositado afirmar que, na prática, não se verificam grandes alterações no regime aplicável a esse tipo de negócio jurídico, já que os contratos de programa devem observar toda a legislação de concessões (art. 13, § 1. ${ }^{\circ}, \mathrm{I}$, da Lei n. ${ }^{\circ}$ 11.107/05). Talvez a única inovação de destaque seja a possibilidade de transferência de bens e pessoal, prevista no caput do art. 13 da Lei de Consórcios Públicos, que por sua vez se fundamenta nitidamente no art. 241 da Constituição Federal.

Indo mais além, seria possível questionar se, em face do advento do contrato de programa, haveria ainda a possibilidade de se continuar a disciplinar por contrato de concessão ou de permissão a prestação de serviços públicos no âmbito da gestão associada. $^{473}$

$\mathrm{O}$ art. 13 da Lei n. ${ }^{\circ}$ 11.107/05 é categórico ao impor a celebração de um contrato de programa como "condição de validade" para a constituição de obrigações entre entes federados, ou entre estes e um consórcio público, quando houver "gestão associada" envolvendo prestação de serviços públicos ou transferência total ou parcial de encargos, serviços, pessoal ou bens necessários à continuidade dos serviços transferidos.

472 RODRÍGUEZ de SANTIAGO, 1997, p. 365-366. Permitimo-nos traduzir os excertos transcritos da seguinte forma, respectivamente: "a existência de relações contratuais de subordinação também entre Administrações Públicas"; "poderia, também, com apoio no direito positivo, articular-se através de um convênio interadministrativo"; e "prerrogativas típicas da contratação administrativa - por exemplo, porque os bens de cada Administração são impenhoráveis também frente às demais”.

${ }^{473}$ Cf., a respeito do tema, PORTO NETO, 2005. 
Dito de outra forma, o ajuste assume "a natureza de condição de validade para a licitude das obrigações que o ente federativo assumir com o objetivo de proceder à gestão associada na execução de atividades administrativas". ${ }^{474}$

Diante de tal exigência, que só prevê como exceção os ajustes dos quais não derivem obrigações jurídicas ( $\$ 7 .^{\circ}$ do art. 13) - que seriam atos informais de cooperação, protocolos, acordos em sentido amplo -, parece não haver ainda espaço para a celebração de um contrato de concessão entre entes federados, ou entre estes e um consórcio público. Mais que isso, torna-se ilícita a realização de qualquer ajuste entre entes da Federação, mesmo que denominado pelas partes "convênio", em que sejam previstas obrigações recíprocas no âmbito da gestão associada de serviços públicos, caso não siga as formalidades do contrato de programa.

Cumpre observar, entretanto, que tais ponderações dependem do que se entenda por "gestão associada". De qualquer forma, a redação do art. 13, caput, demonstra que a vontade do legislador foi a de centralizar na figura dos contratos de programa o regime da gestão e prestação de serviços públicos em atuação compartilhada por dois ou mais entes federativos, tendendo a reservar os tradicionais contratos de concessão para a esfera público-privada.

Assinale-se, por outro lado, que permanece possível a concessão de serviços públicos entre um ente federado e uma entidade da administração indireta, mesmo após a vigência da Lei n. ${ }^{\circ} 11.107 / 05$. Isso porque tais entidades não estão abrangidas pelo caput, de modo que escapam à obrigatoriedade nele contida. Ora, se o $\S 5 .^{\circ}$ do art. 13 exige previsão no instrumento de consórcio público ou de convênio de cooperação para que a entidade da administração indireta celebre contrato de programa, a contrario sensu conclui-se que, sem essa previsão, tais entidades estão proibidas de celebrar contratos de programa. No entanto, nada impede que, com esteio na Lei n. ${ }^{\circ}$ 8.987/95, elas transfiram (ou tenham a si delegada) a prestação de determinados serviços públicos por meio de um contrato de concessão.

Note-se que, caso o contrato de programa tenha sido celebrado por entidade da administração indireta de um ente consorciado ou conveniado, ele poderá vir a se extinguir

${ }^{474}$ CARVALHO FILHO, 2009, p. 131. 
de pleno direito, na hipótese de a referida entidade deixar de fazer parte da administração indireta do ente em questão (art. 13, $\S 6^{\circ}{ }^{\circ}$ ). Ou seja, a título de exemplo, se uma empresa pública que fora contratada, por meio de contrato de programa, para a prestação de serviços de manutenção de uma rodovia vier a ter seu controle acionário transferido à iniciativa privada, deixando, assim, de pertencer à administração indireta do ente que possibilitara a gestão associada do referido serviço, o contrato de programa será automaticamente extinto.

Tal disposição, bem de ver, contrasta com a disciplina legal estabelecida como regra, que pretendeu imprimir segurança às relações jurídicas derivadas da formação de um consórcio público e, especialmente, da celebração de um contrato de programa. Sendo assim, uma possível leitura desse dispositivo poderia levar à conclusão de que o contrato de programa envolvendo alguma entidade da administração indireta seria menos estável que o ajuste de mesma natureza que envolvesse somente entes federados.

Para atenuar essa regra, o Decreto Federal n. ${ }^{\circ}$ 6.017/07 previu, em seu art. 31, $\S 3^{\circ}$, que

$\S 3^{\circ}$. É lícito ao contratante, em caso de contrato de programa celebrado com sociedade de economia mista ou com empresa pública, receber participação societária com o poder especial de impedir a alienação da empresa, a fim de evitar que o contrato de programa seja extinto na conformidade do previsto no $\S 20$ deste artigo.

Vale anotar ainda a observação de Lílian Maria Salvador Guimarães Campos quanto à situação inusitada que a Lei de Consórcios Públicos gerou ao permitir que o contrato de programa enumere as sanções pelo inadimplemento dos encargos transferidos, quando isso costuma ser matéria restrita à lei, ao menos no tocante ao elenco aberto de medidas cabíveis. ${ }^{475}$

${ }^{475}$ CAMPOS, 2006, p. 109. 


\subsubsection{Convênios}

Além das formas de coordenação já expostas, aos consórcios públicos é facultada também a celebração de convênios, tanto de cooperação quanto de colaboração. A possibilidade encontra-se expressa nos arts. $2 .^{\circ}, \S 1 .^{\circ}$, I, e 14 da Lei n. ${ }^{\circ} 11.107 / 05$, mas já decorria do art. $10, \S 1 .^{\circ}, b$ e $\S 5 .^{\circ}$ do Decreto-lei n. ${ }^{\circ} 200 / 67 .{ }^{476}$

Ademais, não há novidade no uso do instituto, que, como se viu, ${ }^{477}$ é corriqueiro na prática da Administração Pública brasileira.

\section{$\underline{\text { 8.10. Responsabilidade }}$}

O consórcio, como pessoa jurídica que é, responde pelas obrigações assumidas com seu próprio patrimônio.

Ressalte-se, a respeito, que os bens afetados à prestação do serviço são impenhoráveis e insuscetíveis de aquisição por usucapião, tenha o consórcio personalidade jurídica de direito público ou de direito privado.

De outra parte, pode-se afirmar que a execução contra o consórcio se faz pelo regime de precatórios (art. 100 da Constituição Federal), em se tratando de associação pública. Já o consórcio de direito privado sujeita-se à legislação processual civil, ressalvada a sobredita impenhorabilidade dos bens relacionados diretamente com os serviços públicos objeto da gestão associada.

A responsabilidade dos consorciados em relação às obrigações assumidas pelo consórcio é subsidiária, em decorrência do veto presidencial ao art. 10, que tinha a seguinte redação:

\footnotetext{
${ }^{476}$ MEDAUAR; OLIVEIRA, 2006, p. 114.

${ }^{477}$ Cf. item 3.3 supra.
} 
Art. 10. Os consorciados respondem solidariamente pelas obrigações assumidas pelo consórcio.

Nas razões do veto, defendeu-se que "a intenção do legislador, aparentemente, era dizer que os consorciados respondem subsidiariamente; contudo, constou que os consorciados respondem solidariamente".

Pelo texto originariamente previsto no art. 10, seria facultado ao credor exigir o cumprimento da obrigação indistintamente do consórcio ou dos entes federados que dele participem, o que levou o Chefe do Executivo federal a alegar prejuízo aos princípios da segurança jurídica e da estabilidade fiscal.

Em face do veto, aplica-se a regra geral da responsabilidade subsidiária da administração indireta, ou seja, o consórcio é quem responde, em princípio, por suas obrigações. Apenas quando não o faça, acude a responsabilidade do Estado, que se afigura, por isso mesmo, subsidiária.

Atingindo-se a responsabilização subsidiária dos entes consorciados, respondem estes solidariamente, "até que haja decisão que indique os responsáveis por cada obrigação [sic]" (art. 12, $\S 2^{\circ}$, da Lei n. $\left.{ }^{o} 11.107 / 05\right)$. Aquele que arcar com a dívida tem direito de regresso contra o ente federado que beneficiou ou deu causa à obrigação.

A solução adotada é a mais natural em face do nosso direito administrativo. Note-se que de modo idêntico funciona, quanto a esse aspecto, o consórcio público na Argentina país cujo direito administrativo compartilha dos mesmos pilares do brasileiro -, onde os terceiros prejudicados podem, mediante prévia incursão no patrimônio da entidade consorcial, acionar os consorciados, que entre si respondem solidariamente. ${ }^{478}$

Ademais, ressalte-se que os agentes públicos encarregados do gerenciamento do consórcio também podem ser responsabilizados, caso pratiquem atos em desconformidade com a lei ou disposições estatutárias (art. 10, parágrafo único).

É da teoria geral do direito que, em regra, os patrimônios (conjunto de direitos e obrigações) das pessoas físicas não se confundem com os das pessoas jurídicas das quais

${ }^{478}$ DROMI, 1996, p. 495. 
sejam sócias ou associadas. A exceção a essa regra se materializa na atual concepção da responsabilidade pessoal do sócio ou administrador que extrapole os poderes a ele conferidos pelo estatuto social. A teoria da responsabilidade ultra vires foi tradicionalmente consagrada, entre nós, no direito societário (arts. 117 e 158, I e II, da Lei n. ${ }^{\circ}$ 6.404/76, e arts. 1.016 e 1.080 do Código Civil) e no direito tributário (art. 135, III, do Código Tributário Nacional).

Aplicação clara dessa teoria, a norma do art. 10, parágrafo único, da Lei de Consórcios Públicos deve ser interpretada em conjunto com a do art. $37, \S 6^{\circ}$, da Constituição Federal, que estabelece a responsabilidade objetiva das pessoas jurídicas de direito público e de direito privado prestadoras de serviços públicos pelos danos causados por seus agentes, respondendo estes, por sua vez, perante a Administração, mas somente se restar comprovado terem agido com culpa ou dolo.

Assim, é possível concluir que os agentes públicos administradores do consórcio, tenha este personalidade jurídica de direito público ou privado, respondem pelas obrigações decorrentes de atos que tenham praticado em contrariedade à lei ou a disposição do estatuto, bem assim por qualquer obrigação derivada de dano causado dolosa ou culposamente a terceiro - mas a Administração, em face do terceiro prejudicado, responde independentemente de culpa.

De outra parte, é certo que tais agentes podem ser responsabilizados também por improbidade administrativa, caso promovam a gestão associada de serviços públicos sem observar as formalidades prescritas na lei (art. 10, XIV da Lei n. ${ }^{\circ} 8.429 / 92$ ) ou celebrem contrato de rateio de consórcio público sem suficiente e prévia dotação orçamentária, ou em desacordo com a forma estabelecida em lei (art. 10, XV da mesma lei). Com efeito, tais condutas passaram a constar explicitamente da Lei de Improbidade Administrativa, por força do art. 18 da Lei de Consórcios Públicos.

A rigor, qualquer ato administrativo que se desvie das normas ou princípios que regem a administração pública configura prática de improbidade administrativa, a teor do art. 11 da Lei n. ${ }^{\circ} 8.429 / 92$. No entanto, a depender da gravidade de tais atos, eles podem se enquadrar nos arts. 9. ${ }^{\circ}$ ou 10 da mesma lei, para os quais são previstas penalidades mais severas que as cominadas para as condutas descritas no art. 11. 
Portanto, ao inserir dois novos incisos no art. 10 da Lei de Improbidade Administrativa, o legislador parece ter buscado mais do que a simples qualificação dos atos descritos como ímprobos, para o que já bastava a previsão do art. 11. A intenção foi a de caracterizar tais atos como causadores de prejuízo ao erário, eis que se encontram no rol exemplificativo de condutas desse tipo.

No entanto, autores como Maria Sylvia Zanella Di Pietro, ${ }^{479}$ Odete Medauar e Gustavo Justino de Oliveira $^{480}$ observam que a prática descrita no inciso XIV não necessariamente acarreta prejuízo ao erário, de modo que o exemplo não se coaduna com o caput do dispositivo. Em conseqüência, poder-se-ia afirmar que tal conduta do administrador do consórcio somente se sujeita às penas do art. 12, II, da Lei de Improbidade se restar devidamente comprovado o prejuízo ao erário. Caso contrário, tratar-se-ia de ato subsumível ao art. 11 e, assim, passível de punição nos termos do art. 12, III, daquele diploma legal.

A esse entendimento poderia ser objetado que a intenção do legislador, ao acrescentar o inciso XIV ao art. 10 da Lei n. ${ }^{\circ}$ 8.429/92, teria sido a de criar uma presunção absoluta de que tal conduta causa prejuízo ao erário. Em outras palavras, teria ele resolvido sujeitar tal comportamento do administrador às penas de maior gravidade, ainda que não se venha a demonstrar o referido prejuízo - hipótese que, em tese, não poderia ser de plano desconsiderada.

Na verdade, se essa foi a intenção do legislador, a maneira de concretizá-la não parece ter sido a mais adequada. O caput do mencionado art. 10 deixa clara a definição de "ato de improbidade administrativa que causa lesão ao erário", assim descrito como a “ação ou omissão, dolosa ou culposa, que enseje perda patrimonial, desvio, apropriação, malbaratamento ou dilapidação dos bens ou haveres" de propriedade pública, "e notadamente", passando a enumerar casos em que o prejuízo se revela de forma explícita ou implícita. Ora, criar uma presunção de que a celebração de contrato ou outro ajuste tendo por objeto a gestão associada de serviços públicos sem observância das formalidades prescritas em lei é ato de improbidade que causa lesão ao erário revela-se expediente no mínimo inusitado. Se o legislador quisesse submeter o autor de tal conduta a penalidades

${ }^{479}$ DI PIETRO, 2006, p. 440-441. 
mais severas que as do art. 12, III, melhor seria que tivesse deixado clara essa intenção, inserindo, por exemplo, um parágrafo ao art. 12 da Lei de Improbidade Administrativa, esclarecendo que também se sujeita às penas do art. 12, II, o administrador que incorrer na prática acima descrita, independentemente da comprovação de prejuízo ao patrimônio público.

Quanto ao novel inciso XV do art. 10, não se colocam maiores indagações, uma vez que a celebração de contrato de rateio não lastreado em dotações orçamentárias inevitavelmente ocasionará prejuízos ao erário, notadamente ao patrimônio do próprio consórcio público.

A responsabilização dos dirigentes do consórcio pode se dar também no campo penal. Ganham relevância sob essa ótica as condutas infringentes de normas financeiras, notadamente as tipificadas nos arts. 359-A, 359-C, 359-D, 359-E e 359-G do Código Penal:

Art. 359-A. Ordenar, autorizar ou realizar operação de crédito, interno ou externo, sem prévia autorização legislativa: (Incluído pela Lei $\mathrm{n}^{\circ} 10.028$, de 2000)

Pena - reclusão, de 1 (um) a 2 (dois) anos. (Incluído pela Lei n 10.028, de 2000)

Parágrafo único. Incide na mesma pena quem ordena, autoriza ou realiza operação de crédito, interno ou externo: (Incluído pela Lei $n^{\circ} 10.028$, de 2000)

I - com inobservância de limite, condição ou montante estabelecido em lei ou em resolução do Senado Federal; (Incluído pela Lei no 10.028, de 2000)

II - quando o montante da dívida consolidada ultrapassa o limite máximo autorizado por lei. (Incluído pela Lei n ${ }^{\circ} 10.028$, de 2000)

$[\ldots]$

${ }^{480}$ MEDAUAR; OLIVEIRA, 2006, p. 123. 
Art. 359-C. Ordenar ou autorizar a assunção de obrigação, nos dois últimos quadrimestres do último ano do mandato ou legislatura, cuja despesa não possa ser paga no mesmo exercício financeiro ou, caso reste parcela a ser paga no exercício seguinte, que não tenha contrapartida suficiente de disponibilidade de caixa: (Incluído pela Lei $n^{\circ} 10.028$, de 2000)

Pena - reclusão, de 1 (um) a 4 (quatro) anos.(Incluído pela Lei no 10.028, de 2000)

Art. 359-D. Ordenar despesa não autorizada por lei: (Incluído pela Lei ${ }^{\circ}$ 10.028, de 2000)

Pena - reclusão, de 1 (um) a 4 (quatro) anos. (Incluído pela Lei nº 10.028, de 2000)

Art. 359-E. Prestar garantia em operação de crédito sem que tenha sido constituída contragarantia em valor igual ou superior ao valor da garantia prestada, na forma da lei: (Incluído pela Lei $n^{\circ} 10.028$, de 2000)

Pena - detenção, de 3 (três) meses a 1 (um) ano. (Incluído pela Lei $n^{\circ}$ 10.028, de 2000)

$[\ldots]$

Art. 359-G. Ordenar, autorizar ou executar ato que acarrete aumento de despesa total com pessoal, nos cento e oitenta dias anteriores ao final do mandato ou da legislatura: (Incluído pela Lei $\mathrm{n}^{\circ} 10.028$, de 2000))

Pena - reclusão, de 1 (um) a 4 (quatro) anos. (Incluído pela Lei nº 10.028, de 2000)

Ademais, o Presidente da República, ao representar a União em um consórcio público, e os Governadores sujeitam-se às normas incriminadoras estatuídas na Lei de Crimes de Responsabilidade (Lei n. ${ }^{\circ}$ 1.079/50), da mesma forma que os prefeitos submetem-se aos dispositivos penais do Decreto-lei n. ${ }^{\text {2 }}$ 201/67.

Além disso, não seria despiciendo acrescentar que todos os funcionários de um consórcio, tenha ele personalidade pública ou privada, enquadram-se na categoria de funcionários públicos para os fins penais (art. 327 do Código Penal), advindo daí a 
possibilidade de figurarem como sujeitos ativos de crimes próprios dessa categoria, como o peculato, a prevaricação, a concussão e outros. 


\section{ALTERAÇÃo E EXTINÇÃo DO CONSÓRCIO PÚBLICO}

\subsection{Modificação}

Toda alteração do contrato de consórcio público depende de lei. Nem poderia ser diferente, uma vez que as cláusulas originárias foram ratificadas por lei. Logo, dispensar a ratificação legislativa implicaria permitir a fraude à vontade do legislador, já que o protocolo de intenções poderia ser apresentado e aprovado pelo Legislativo com uma determinada configuração para, em seguida, ser modificado livremente pelos representantes do consórcio na assembléia geral, podendo vir a tomar forma completamente diferente da que fora inicialmente autorizada.

A alteração e a extinção do consórcio público precisam também ser aprovadas pela assembléia geral de associados.

Para Marcelo Harger, caso um dos consorciados não ratifique a alteração ou extinção do consórcio, este continua a existir sem qualquer modificação, a não ser em hipótese de retirada voluntária ou exclusão de ente. ${ }^{481}$

Dentre as modificações que podem se abater sobre os consórcios públicos, avultam aquelas que dizem com sua própria composição.

Como nos lembra Marçal Justen Filho, “a autonomia intrínseca à Federação assegura aos diversos entes federados a competência para a estruturação de sua administração indireta [...]", compreendendo "não apenas o poder de associar-se como de desligar-se do consórcio". ${ }^{482}$

Embora a lei silencie a respeito, a interpretação sistemática de seus dispositivos leva a crer que a entrada de um novo ente é permitida, desde que este submeta a seu Poder Legislativo, para ratificação, o próprio contrato consorcial a que pretende aderir, e desde que os demais entes também aceitem, por meio de lei, a alteração. Nesse sentido, assim estatui o $\S 6^{\circ}$ do art. $6^{\circ}$ do Decreto n. ${ }^{\circ} 6.017 / 07$ :

${ }^{481}$ HARGER, 2007, p. 162-163. 
$\S 6^{\circ}$ Dependerá de alteração do contrato de consórcio público o ingresso de ente da Federação não mencionado no protocolo de intenções como possível integrante do consórcio público.

Por outro lado, parece desbordar do regramento legal a previsão, também contida no regulamento federal, que considera automaticamente integrantes do consórcio os novos entes federativos resultantes de criação, fusão, incorporação ou desmembramento de ente já consorciado. ${ }^{483}$

Em contrapartida, conforme já foi visto, o ente consorciado que não destina as verbas necessárias ao cumprimento do contrato de rateio pode ser excluído, após prévia suspensão (art. 8. $.^{\circ}, 5^{\circ}{ }^{\circ}$ ).

Além desse caso, nada impede que haja outras hipóteses de exclusão previstas no protocolo de intenções. Assim entende também Marcelo Harger, pela aplicação do art. 57 do Código Civil. ${ }^{484}$

Nesses casos, também há modificação do contrato de consórcio, em seu aspecto subjetivo. Logo, a princípio, também a exclusão precisaria contar com a ratificação legislativa de cada um dos entes participantes do consórcio. No entanto, seria necessária lei do próprio ente excluído? Em relação a ele, opera-se a extinção do consórcio, que também demanda ratificação por lei (art. 12, caput), até porque significa a eliminação de uma entidade da administração indireta que fora instituída por lei. Mas, ao mesmo tempo, parece incoerente esperar que o próprio ente expulso venha a editar lei ratificando sua saída, a qual se teria dado, provavelmente, contra a sua vontade. Desse modo, forçoso concluir que a exclusão de ente consorciado exige deliberação da assembléia geral do consórcio ratificada por lei de cada um dos partícipes, com exceção do excluído. A lei deste último que autorizava sua participação no consórcio público continua vigente, porém sem eficácia, dada a decisão tomada pela assembléia consorcial.

\footnotetext{
482 JUSTEN FILHO, 2005c.

${ }^{483}$ HARGER, 2007, p. 168.

${ }^{484}$ Ibid., p. 166.
} 
Já a previsão de retirada voluntária do ente consorciado (art. 11) possibilita a livre denúncia do ajuste, a qualquer tempo. Isso não significa, entretanto, negar sua conformação contratual. De fato, a existência de obrigações recíprocas não se mitiga com a possibilidade de retirada voluntária do consórcio, mesmo porque tais obrigações persistem contra o ente que se retira (art. 11, $22^{\circ}$ ). Longe de infirmar o caráter contratual do acordo, a previsão do art. 11 se compatibiliza com o princípio da autonomia da vontade e, neste caso especificamente, com o postulado da autonomia dos entes federativos.

Vladimir Alves observa que não se faz necessária a edição de lei específica disciplinando os "termos da retirada", como o tratamento a ser dado aos bens envolvidos, mas tão-somente prevendo o recesso em si, podendo os demais assuntos ser regulados no contrato de consórcio público ou no instrumento de transferência ou alienação dos bens. ${ }^{485}$

A estabilidade do consórcio público, que se procurou conquistar com a sua personificação, decerto sofre um abalo com a possibilidade de retirada incontinenti do ente participante. Porém, cabe reconhecer que outra não poderia ser a solução da lei, eis que impedir a retirada de um dos partícipes feriria o princípio federativo.

De todo modo, a própria lei acaba por minimizar esse conflito latente entre a autonomia dos entes federados e a estabilidade da atuação consorciada, prevendo, especialmente no $\S 2^{\circ}$ do art. 11, que, de um lado, as obrigações do ente que se retira, incluindo aquelas decorrentes de eventual contrato de programa em execução, persistem, e, de outro, a extinção dos deveres assumidos não se opera senão quando acompanhada do pagamento das indenizações porventura devidas.

Destarte, intenta-se garantir, de certa forma, a segurança das relações jurídicas protagonizadas pelo consórcio público, sem, no entanto, afetar-se a autonomia das entidades federativas.

O ato de retirada voluntária é formal, isto é, depende de instrumento a ser apresentado à assembléia geral.

${ }^{485}$ ALVES, 2006, p. 144. 
Segundo Marcelo Harger, o direito de retirada deve ser disciplinado no protocolo de intenções ou na lei que regule a participação do ente federado no consórcio, para que neste não coexistam diferentes formas de exercício do direito de retirada. ${ }^{486}$

O caput do art. 11, ao falar na necessidade de lei, refere-se a norma do próprio ente que se retira. ${ }^{487}$ Lembre-se, outrossim, que todo ato de modificação da estrutura administrativa estatal - no sentido de criação ou extinção de pessoa jurídica integrante dos quadros da Administração - deve pautar-se em previsão legal. Em se tratando da criação ou extinção de uma autarquia (incluindo uma associação pública), mostra-se necessária não simplesmente uma lei autorizadora, que bastaria no caso de empresas públicas, sociedades de economia mista e fundações instituídas e mantidas pelo Poder Público, mas uma lei específica para a situação concreta, a teor do art. 37, XIX, da Constituição Federal. É dizer, em regra, somente por meio de lei se pode criar uma autarquia e, por raciocínio análogo, eliminá-la do arranjo estatal. ${ }^{488}$

Sendo assim, e considerando-se que a associação pública integra a administração indireta de cada um dos entes consorciados, ${ }^{489}$ sua supressão da estrutura estatal do ente que se retira, a qual seria conseqüência inevitável da própria retirada, dependeria de lei específica.

Ocorre que o art. 11 da Lei n. ${ }^{\circ} 11.107 / 05$ exige tão-somente que a saída voluntária do partícipe (e, em decorrência desta, a extinção da associação pública - ao menos em relação à estrutura administrativa da entidade que se retira) seja exteriorizada por "ato formal de seu representante na assembléia geral, na forma previamente disciplinada por lei”. Ou seja, para a extinção da associação pública seria suficiente a manifestação formal de seu representante, desde que conte com autorização legal para tanto.

É de se questionar, todavia, a constitucionalidade dessa norma, frente ao disposto no art. 37, XIX, da Constituição Federal.

${ }^{486}$ HARGER, 2007, p. 163-164.

${ }^{487}$ Nesse sentido, MEDAUAR; OLIVEIRA, 2006, p. 97.

${ }^{488}$ SUNDFELD, Carlos Ari. Reforma do Estado e empresas estatais: a participação privada nas empresas estatais. In: SUNDFELD, Carlos Ari (Coord.). Direito administrativo econômico. São Paulo: Sociedade Brasileira de Direito Público: Malheiros Editores, 2000. p. 282.

${ }^{489}$ Cf. item 6.1.3.1 supra. 
Talvez para resolver tal situação, o art. $2^{\circ}$, IV, do Decreto n. ${ }^{\circ}$ 6.017/07 veio a exigir lei que ratificasse o ato de retirada do consórcio, solução que nos parece mais acertada. Ainda assim, no entanto, a questão não se encontra pacificada, havendo quem acuse a previsão regulamentar de inconstitucionalidade, justamente por exigir requisito (ratificação legal) que não constava da Lei n. ${ }^{\circ} 11.107 / 05 .^{490}$

Quanto aos consórcios públicos constituídos sob a forma de associação civil, a retirada do partícipe também depende de manifestação formal autorizada por lei, eis que o art. 11 da Lei de Consórcios Públicos não faz distinção no tocante à natureza do consórcio.

Se o consórcio com personalidade de direito privado é considerado integrante da administração indireta do ente consorciado, ${ }^{491}$ a necessidade de autorização legislativa para sua extinção já emana do art. 37, XIX, da Constituição, bem como do próprio princípio da legalidade. E mesmo que se entendesse que o consórcio não faz parte da Administração Pública de nenhum dos entes participantes, a retirada de um deles ainda assim precisaria de autorização legislativa, não só porque a lei expressamente a exige, como também porque a instituição do consórcio dependera de ratificação legislativa, afigurando-se coerente e necessário que sua eliminação também passe pelo crivo do parlamento. ${ }^{492}$ Outrossim, nunca é demais recordar que o Poder Público só pode fazer o que a lei expressamente permite (princípio da legalidade estrita), de modo que, uma vez afastada a questão da inconstitucionalidade da exigência de autorização legislativa para a celebração de um contrato de consórcio público, ${ }^{493}$ revela-se apropriada tal autorização também para a denúncia do ente consorciado.

\subsection{Extinção}

\footnotetext{
${ }^{490}$ HARGER, 2007, p. 163. Nota de rodapé n. 358.

${ }^{491}$ Cf. item 6.1.3.2 supra.

${ }^{492}$ Pela necessidade de lei autorizando a retirada, sobretudo pelo fato de ter sido necessária lei para admitir a participação do ente no consórcio, cf. CAMPOS, 2006, p. 105.

${ }^{493}$ Cf. item 7.4 supra.
} 
A extinção do consórcio pode se dar, basicamente, pela consecução de sua finalidade institucional, pelo exaurimento de seu prazo de duração, por livre decisão conjunta das partes, ratificada por lei, ou pela retirada ou exclusão de membros, de modo que reste apenas um deles ou nenhum.

Além disso, é de se ter em conta também a hipótese de, em se tratando de associação civil, o consórcio ser dissolvido nos casos previstos no estatuto (art. 54, VI, do Código Civil), ou mesmo judicialmente, em caso de inexeqüibilidade.

Em caso de extinção, os bens, direitos, encargos e obrigações decorrentes da gestão associada de serviços públicos custeados por tarifas ou outra espécie de preço público retornarão à responsabilidade dos entes federados titulares dos respectivos serviços (art. $12, \S 1^{\circ}$, da Lei de Consórcios Públicos).

\subsubsection{Obrigações remanescentes}

Quando cessam as atividades do consórcio público, nem por isso desaparecem suas obrigações, o que seria temerário para os princípios da segurança jurídica e da continuidade dos serviços públicos.

Assim, dispõem os arts. 11, § 2. ${ }^{\circ}$, e 12, § 1. ${ }^{\circ}$, da Lei de Consórcios Públicos:

Art. 11.

$[\ldots]$

$\S 2 .^{\circ}$ A retirada ou a extinção do consórcio público não prejudicará as obrigações já constituídas, inclusive os contratos de programa, cuja extinção dependerá do prévio pagamento das indenizações eventualmente devidas.

Art. 12. 
$\S 1 .^{\circ}$ Os bens, direitos, encargos e obrigações decorrentes da gestão associada de serviços públicos custeados por tarifas ou outra espécie de preço público serão atribuídos aos titulares dos respectivos serviços.

Verifica-se que, da mesma forma que sucede em caso de retirada de um ente consorciado, buscou-se resguardar a segurança das relações jurídicas também contra a própria extinção do consórcio. Logo, mesmo que o consórcio público deixe de existir, permanecem as obrigações já formalmente assumidas, incluindo eventual contrato de programa.

Em que pese a redação imprecisa do art. $12, \S 1^{\circ}$, é certo que tal dispositivo dirigese apenas às hipóteses de extinção do consórcio, ou de alteração que elimine a gestão associada de serviços públicos, e não a qualquer modificação, como se depreenderia de uma leitura à luz do próprio caput do artigo. Isso porque, quando a alteração não impedir a subsistência da gestão associada ou prestação do serviço público objeto do consórcio como, por exemplo, no caso da retirada de apenas um ente de um consórcio composto por mais de dois, ou mesmo da singela modificação de uma cláusula relativa à remuneração do pessoal -, não há motivo para se atribuírem os bens, direitos, encargos e obrigações aos titulares dos respectivos serviços.

\subsubsection{Subsistência dos contratos de programa}

Além da regra inscrita no art. $11, \S 2^{\circ}$, da Lei de Consórcios Públicos, também a norma do art. $13, \S 4^{\circ}$, que consagra a autonomia do contrato de programa em relação ao contrato de consórcio público, demonstra a consistência que se pretendeu imprimir a tal instrumento de atuação associada.

Segundo ensina José dos Santos Carvalho Filho, “a lei privilegiou a continuidade do contrato de programa em virtude das obrigações que foram contraídas, inconfundíveis com as que advieram do anterior instrumento de autorização". 494

${ }^{494}$ CARVALHO FILHO, 2009, p. 154. 
Com efeito, a previsão de que o contrato de programa permanece em vigor mesmo quando extinto o consórcio público ou convênio de cooperação que autorizou a gestão associada de serviços públicos homenageia os princípios da segurança jurídica e da proteção da confiança legítima, ${ }^{495}$ fornecendo bases sólidas para que os diversos entes federativos, órgãos e entidades públicas lancem mão dessa nova forma de prestação compartilhada de serviços públicos, com larga vantagem, nesse aspecto, em relação aos tradicionais convênios administrativos.

Além disso, a sobrevivência do contrato de programa busca garantir ainda a continuidade da prestação dos serviços públicos envolvidos, eis que, "se de serviço público se trata, não pode o mesmo sofrer solução de continuidade em detrimento dos usuários". 496

Em que pese possa parecer, de certo modo, pouco comum a idéia de ultratividade de um contrato, mesmo com a extinção de uma de suas partes, cabe observar que, especificamente em relação ao contrato de programa, o ordenamento jurídico oferece suporte a essa possibilidade por meio de expressa previsão legal.

${ }^{495}$ Cf., a respeito do princípio da tutela da confiança legítima, BAPTISTA, Patrícia. A tutela da confiança legítima como limite ao exercício do poder normativo da Administração Pública: a proteção das expectativas legítimas dos cidadãos como limite à retroatividade da norma. Revista Eletrônica de Direito do Estado (REDE), Salvador: Instituto Brasileiro de Direito Público, n. 11, jul./set. 2007. Disponível em: <http://www.direitodoestado.com.br/rede.asp >. Acesso em: 14 ago. 2008.

${ }^{496}$ CARVALHO FILHO, 2009, p. 155. 


\section{FISCALIZAÇÃo DO CONSÓRCIO PÚBLICO}

\subsection{Considerações preliminares}

O consórcio público sujeita-se a um complexo sistema de controle, interno e externo. Controle interno, segundo a doutrina, é aquele realizado pela própria entidade controlada, sendo externo o efetuado por outra entidade. ${ }^{497}$ Geralmente se diz externo do controle feito por um Poder sobre outro, assim também como do controle exercido pela administração direta sobre a indireta. ${ }^{498}$

Como se viu, o consórcio público é pessoa jurídica pertencente, simultaneamente, à estrutura administrativa de mais de um ente da Federação. Nessa condição, submete-se a controle por parte de órgão integrante de sua própria estrutura, e também por parte da administração direta de cada consorciado, assim como do Legislativo e do Judiciário. Ao primeiro tipo de controle chamaremos interno, sendo os demais considerados, para efeito deste estudo, modalidades de controle externo, ainda que possam originar-se do próprio Poder Executivo.

\subsection{Controle interno}

O estatuto deve prever o funcionamento de órgão técnico responsável pela fiscalização interna dos atos emanados do consórcio. Embora a lei não o diga expressamente, é certo que a existência de órgão dessa natureza seria vital no atendimento aos primados de legalidade, moralidade e eficiência da atividade administrativa. De mais a mais, o próprio Decreto n. ${ }^{\circ}$ 6.017/07 menciona o controle interno, ao tratar do contrato de rateio. $^{499}$

${ }^{497}$ GASPARINI, 2006, p. 887.

${ }^{498}$ DI PIETRO, 2005b, p. 638.

499 “Art. 13. Os entes consorciados somente entregarão recursos financeiros ao consórcio público mediante contrato de rateio. 
O órgão de controle interno - um Conselho Fiscal, por exemplo - terá condições de determinar a revisão de atos tidos por inválidos, inconvenientes ou inoportunos, ou mesmo propor a solução à Assembléia Geral.

\subsection{Controle externo}

Além de se submeter, na qualidade de entidade da administração indireta de todos os entes consorciados, à tutela emanada da administração direta de cada um deles (e que, no caso da administração federal, fundamenta-se no art. 19 do Decreto-lei n. ${ }^{\circ}$ 200/67), o consórcio está sujeito também à fiscalização dos Tribunais de Contas, por lidar com dinheiro público (arts. 70, caput e parágrafo único, e 71 e incisos da Constituição Federal e 9. ${ }^{\circ}$, parágrafo único, da Lei n. $\left.{ }^{\circ} 11.107 / 05\right)$. No entanto, pode ocorrer que nem todos os partícipes do consórcio se sujeitem ao mesmo Tribunal de Contas, como no caso de um consórcio composto pela União, por diversos Estados e por Municípios contidos no território de um desses Estados. Em hipóteses como essa, diversos tribunais teriam, em tese, competência para fiscalizar a gestão financeira do consórcio, o que geraria um indesejável conflito.

A Lei de Consórcios, em seu art. $9^{\circ}$, parágrafo único, procura resolver a questão determinando como competente o tribunal que o é para apreciar as contas do Chefe do Poder Executivo representante legal do consórcio.

Mas a disposição, mesmo com a ressalva trazida em sua parte final, ${ }^{500}$ revela-se em evidente confronto com os arts. 70 e 71 da Constituição Federal, que estabelecem, de modo geral, o sistema de controle externo da administração, a ser levado a efeito pelo Poder Legislativo, com o auxílio do Tribunal de Contas. Ora, é nítido, por exemplo, que o dispositivo legal passa ao largo da previsão do art. 71, VI da Lei Maior, que concede ao

\section{[...]}

$\S 3 .^{\circ}$ As cláusulas do contrato de rateio não poderão conter disposição tendente a afastar, ou dificultar a fiscalização exercida pelos órgãos de controle interno e externo ou pela sociedade civil de qualquer dos entes da Federação consorciados."

${ }^{500}$ No sentido de que a fiscalização se daria "sem prejuízo do controle externo a ser exercido em razão de cada um dos contratos de rateio". 
Tribunal de Contas da União competência para "fisscalizar a aplicação de quaisquer recursos repassados pela União mediante convênio, acordo, ajuste ou outros instrumentos congêneres, a Estado, ao Distrito Federal ou a Município”. Da mesma forma, é inequívoco que uma autarquia federal não pode escapar à fiscalização do TCU (art. 71, incisos II, III e IV, da Constituição Federal). Mesmo se instituído sob a forma de associação civil, o consórcio de que participe a União se submete à referida Corte, por manipular verbas públicas federais.

Com o devido respeito às opiniões divergentes, dentre as quais as de Odete Medauar e Gustavo Justino de Oliveira - para quem o art. $9^{\circ}$, parágrafo único, da Lei n. ${ }^{\circ}$ 11.107/05 "está harmonizado com as disposições constitucionais que regem a fiscalização contábil, financeira, orçamentária, operacional e patrimonial das entidades públicas e das entidades privadas que realizam a gestão de recursos públicos", ${ }^{501}$ e de Lílian Maria Salvador Guimarães Campos, para quem a fiscalização por um único Tribunal de Contas é solução inteligente, mas que depende "da criação de um sistema de controle externo nacional, a fim de que a autonomia fiscalizatória dos Tribunais de Contas não seja violada", ${ }^{502}$ acredita-se inevitável permitir que concorram, para o controle externo do consórcio, diferentes Cortes de Contas, a depender da composição da entidade associativa, sob pena de se violar a Constituição Federal.

Certamente a fiscalização pelos Tribunais de Contas consiste em problema grave a ser enfrentado na prática dos consórcios públicos, motivo pelo qual Marçal Justen Filho sugere a possibilidade, que endossamos, de se celebrar um convênio entre as diferentes Cortes envolvidas. ${ }^{503}$ Tal convênio poderia ao menos fornecer uma organização dos métodos a serem adotados, talvez indicando as atribuições que cada um dos Tribunais preferencialmente exerceria, sem a possibilidade, ressalte-se, de excluir a competência daqueles que a detêm por mandamento constitucional.

A fiscalização dos consórcios, quanto aos aspectos financeiros e administrativos, passa pela possibilidade de responsabilização dos agentes administradores da entidade por atos de improbidade administrativa, ou mesmo por crimes cometidos no exercício das

\footnotetext{
${ }^{501}$ MEDAUAR; OLIVEIRA, 2006, p. 94.

${ }^{502}$ CAMPOS, 2006, p. 105.

${ }^{503}$ JUSTEN FILHO, 2005b, p. 124.
} 
funções, relacionados à malversação de recursos públicos. ${ }^{504}$ Atua nesses casos o controle exercido externamente pelo Poder Judiciário, mediante provocação de qualquer cidadão que tem à sua disposição a ação popular - ou das entidades legalmente legitimadas para tanto, dentre as quais deve-se destacar, pelo alcance de sua legitimação extraordinária e pelo papel constitucionalmente conferido, o Ministério Público.

${ }^{504}$ Cf. item 8.8 supra. 


\section{OS CONSÓRCIOS NA PRÁTICA DA ADMINISTRAÇÃo BRASILEIRA}

\subsection{Considerações gerais}

O Brasil, como se sabe, é um país que apresenta enormes desigualdades sociais e econômicas, que se refletem no intenso desequilíbrio entre suas regiões mais pobres e mais desenvolvidas. Tais desigualdades se repetem também nos milhares de Municípios existentes.

Como se nota das informações trazidas por Lílian Maria Salvador Guimarães Campos, ${ }^{505}$ baseadas no estudo de Luiz César de Queiroz Ribeiro, ${ }^{506}$ em nosso país convivem Municípios como São Paulo, com mais de 10,6 milhões de habitantes, e Borá, também no Estado de São Paulo, com cerca de 800 moradores. Além disso, é igualmente revelador o dado de que

embora pouco mais de $20 \%$ da população brasileira viva em municípios com até 20 mil habitantes, estes representam $73 \%$ do total de municípios existentes no país. No outro extremo, em apenas $0,6 \%$ dos municípios, ou seja, 32 deles, residem 48 milhões de brasileiros, o que representa $27,8 \%$ da população do país. ${ }^{507}$

Tais diferenças entre Municípios demonstram que a auto-suficiência de alguns deles, assemelhados a verdadeiros Estados, contrasta com a hipossuficiência das comunas que sequer contam com população suficiente para contribuir com os tributos mínimos a viabilizarem sua auto-administração.

${ }^{505}$ CAMPOS, 2006, p. 80.

${ }^{506}$ RIBEIRO, Luiz César de Queiroz (Org.). O futuro das metrópoles: desigualdades e governabilidade. Rio de Janeiro: Revan: Federação de Órgãos para Assistência Social e Educacional (FASE), 2000. p. 23-25.

${ }^{507}$ RIBEIRO, 2000, apud CAMPOS, 2006, p. 80. 
Esse quadro é cenário propício para o desenvolvimento de mecanismos de auxílio mútuo com vistas à gestão de serviços sob a forma associada.

Além das vantagens econômicas evidentemente percebidas pelos entes locais que se reúnem em consórcio, caberia ressaltar ainda dois fatores de estímulo político e social sublinhados por Solange Gonçalves Dias: o aumento da transparência das decisões públicas, eis que, "ao envolver vários centros de poder, suas decisões têm viabilidade ampla em cada localidade e também no âmbito regional"; e "o potencial de aumento do poder de diálogo, pressão e negociação dos Municípios frente aos governos estadual e federal ou frente a instituições sociais ou organismos internacionais". 508

Atentos ou não a tais ganhos, fato é que centenas de consórcios administrativos já funcionam no país. Conforme já foi assinalado, o IBGE dá notícia de que no Brasil, até 2005, havia 4.537 registros de consorciamento intermunicipal, sendo 1.906 apenas na área da saúde. ${ }^{509}$

Conquanto os consórcios carecessem, até 2005, de regras claras para sua formação, a necessidade prática, aliada à engenhosidade dos governantes municipais, levou à estruturação de consórcios bastante complexos, guiados por regras próprias similares às que seriam introduzidas pela Lei n. ${ }^{\circ} 11.107 / 05$.

Em Minas Gerais, por exemplo, o Consórcio do Alto São Francisco, que reúne 26 Municípios objetivando a prestação de serviços de saúde, há mais de uma década formouse mediante a elaboração de projeto de lei submetido a cada uma das Câmaras Municipais participantes, que autorizavam, com isso, a destinação de verbas para o consórcio. Em seguida, foi elaborado o estatuto consorcial, submetido aos prefeitos dos municípios consorciados, ocasião em que se definiu ainda a cidade-sede do consórcio, bem como seu presidente. Além disso, constituiu-se uma associação civil para administrar o consórcio, criando-se os órgãos responsáveis pelas diferentes atribuições administrativas. A

\footnotetext{
${ }^{508}$ DIAS, 2006, p. 78.

${ }^{509}$ COORDENAÇÃO de população e indicadores sociais. In: INSTITUTO BRASILEIRO DE GEOGRAFIA E ESTATÍSTICA (IBGE). Perfil dos municípios brasileiros: gestão pública 2005. Rio de Janeiro, 2006. Disponível em: <http://www.ibge.gov.br/home/estatistica/economia/perfilmunic/2005/munic2005.pdf > Acesso em: 11 nov. 2008. Cf. item 4.2 supra.
} 
formalização da pessoa jurídica contribuiu para que o programa continuasse mesmo com a troca de gestões municipais. ${ }^{510}$

Desde 2005, tem crescido a perspectiva de formação de consórcios, diante da novel legislação a respeito do tema. Com efeito, "pode-se afirmar que existe um conjunto positivado de regras essenciais aos consórcios que, ainda que não esteja completamente aperfeiçoado, pode ser denominado de regime consorcial". 511

A Lei 11.107/05 não alcança os "convênios de cooperação, contratos de programa para gestão associada de serviços públicos ou instrumentos congêneres que tenham sido celebrados anteriormente a sua vigência" (art. 19). Isso não quer dizer que não seja mais possível a constituição de um consórcio administrativo, ou seja, de um consórcio destituído de personalidade jurídica. Com efeito, nada impede que os entes federados firmem ajustes para cooperação em bases mais precárias, sem a instituição de uma pessoa jurídica. Tal instrumento, contudo, seria formalizado à margem da disciplina dos consórcios públicos, não apresentando outra natureza senão a de um tradicional convênio administrativo.

Nesse sentido, Hely Lopes Meirelles - ou, mais precisamente, os atualizadores de sua obra - esclarece remanescerem "os consórcios administrativos sem personalidade jurídica, conceituados como acordos firmados entre entidades autárquicas, fundacionais ou paraestatais, da mesma espécie". 512

Se, de um lado, o advento de um norte legislativo para a formação de consórcios públicos pode exigir maior cuidado dos administradores ao buscarem a cooperação interfederativa - que agora se sujeita a inúmeras regras -, fazendo com que o consorciamento se torne mais complexo e, quiçá, menos freqüente, de outro, é certo que os consórcios públicos que surgirem tendem a ganhar em eficiência, eis que se erguem em sólidos alicerces normativos.

Para se valerem das vantagens trazidas pelo novo regime jurídico dos consórcios públicos, os consórcios administrativos já existentes começam a se mobilizar para adequarem seus estatutos.

\footnotetext{
${ }^{510}$ SOARES, Ana Paula Macedo. Consórcio intermunicipal de Saúde: Fundação Perseu Abramo. Disponível em: 〈http://www2.fpa.org.br/portal/modules/news/article.php?storyid=2606>. Acesso em: 11 nov. 2008.

${ }^{511}$ SILVA, C. D. O., 2005 a.
} 
De acordo com levantamento do Instituto Brasileiro de Geografia e Estatística IBGE, ${ }^{513}$ existe no Brasil um número impressionante de consórcios constituídos entre diferentes entes federativos, algo que só se poderia implementar após a Lei n. ${ }^{\circ}$ 11.107/05. São 7.103 registros de consorciamento entre Municípios e Estados. O número é maior que a quantidade de Municípios existentes no Brasil, o que se explica pela metodologia usada pelo IBGE: foram remetidos questionários aos representantes municipais, que responderam se os respectivos Municípios participavam de consórcios nas mais diversas áreas. Assim, cada edilidade poderia apontar a participação em mais de um consórcio (por exemplo, nas áreas de turismo e educação), o que de fato se deu.

Também no levantamento dos consórcios entre Estado e Município destaca-se a área de saúde (1.167 casos), seguida por educação (1.116) e assistência e desenvolvimento social (867). ${ }^{514}$

Igualmente significativa é a prática de consorciamento entre Municípios e União, que soma 4.152 contratos, com destaque para educação (767 casos) e assistência (660 casos). ${ }^{515}$

Como exemplo da adaptação à nova legislação de regência, tem-se que os representantes do Consórcio Intermunicipal de Saúde CIS/AMUNPAR, que congrega 28 municípios do noroeste paranaense, decidiram, em assembléia realizada em julho de 2007 , adaptar-se às novas regras sobre consórcios públicos, tendo em seguida elaborado protocolo de intenções que aguarda aprovação pelo Legislativo de cada um dos partícipes.

De fato, é de se presumir que a criação das pessoas jurídicas consorciais traga maior estabilidade e segurança jurídica para a condução das atividades associadas, mormente sob o ponto de vista negocial.

Além disso, se a forma escolhida for a de associação pública, que de fato se mostra a mais condizente com o nosso ordenamento jurídico, o consórcio usufruirá ainda das prerrogativas inerentes ao Poder Público, como os maiores prazos processuais (art. 188 do

\footnotetext{
${ }^{512}$ MEIRELLES, 2006, p. 425-426.

${ }^{513}$ COORDENAÇÃO de população e indicadores sociais, 2006, p. 154-161.

${ }^{514}$ Ibid., tabela 38 , p. 156-157.

${ }^{515}$ Ibid., tabela 39, p. 158-159.
} 
Código de Processo Civil), a prescrição qüinqüenal das ações que impugnem atos seus (art. 1. ${ }^{\circ}$ do Decreto n. ${ }^{\circ}$ 20.910/32), o juízo privativo (art. 109, I da Constituição Federal e dispositivos das diversas leis de organização judiciária estadual), a inalienabilidade, impenhorabilidade e imprescritibilidade dos seus bens (arts. 100 do Código Civil, 649, I do Código de Processo Civil, 100, 183, § 3.․, e 191, parágrafo único, da Constituição Federal), a possibilidade de inserção, nos contratos que vier a celebrar, de cláusulas exorbitantes (art. 58 da Lei n. ${ }^{\circ}$ 8.666/93), o procedimento especial para execução de seus créditos (Lei n. ${ }^{\circ}$ 6.830/80) e débitos (art. 100 da Constituição Federal; arts. 730 e 731 do Código de Processo Civil), a imunidade tributária (art. 150, VI, $a$ da Lei Maior), dentre outros. 


\section{CONCLUSÃO}

A análise dos consórcios públicos no direito brasileiro demanda a compreensão da dimensão federalista do fenômeno, em especial das bases sobre que se assenta o federalismo cooperativo no século XXI.

A evolução do modelo federal tem mostrado a tendência de as unidades subnacionais se interligarem gradativamente, espelhando a necessidade sentida pelos governos locais de enveredar pela trilha de um arranjo político-administrativo que permita o desempenho mais eficiente das tarefas atribuídas pela Constituição.

O incremento da coordenação converge também das modificações havidas no direito administrativo, relacionadas às mudanças sobre a concepção do papel do Estado junto ao mercado e à sociedade de modo geral.

Em conseqüência, entre outros fatores, dos avanços científicos e tecnológicos havidos no último século, a sociedade vem passando a enxergar o Estado e a Administração Pública não mais como instrumentos de grupos ou classes, mas como garantes e executores de interesses gerais. ${ }^{516}$ Surge uma "sociedade pluriclasse", a qual, segundo Diogo de Figueiredo Moreira Neto, é a sociedade da era das mobilidades - social, financeira, da produção e da informação. ${ }^{517}$

Assim, com a derrocada do Estado de Direito e, após, do Estado Social, surge o Estado Democrático (ou Estado de Direito Democrático e Social), caracterizado pela maior participação popular no processo político, nas decisões de Governo e no controle da administração pública. ${ }^{518}$

Em meio a esse contexto, a reforma do aparelhamento administrativo veio reduzir a máquina estatal, com a proposta de torná-la mais ágil e eficiente. Para tanto, multiplicaram-se as formas de coordenação gerencial na Administração Pública, inclusive estimulando-se a gestão associada de serviços públicos.

\footnotetext{
${ }^{516}$ CAMPOS, 2006, p. 3.

${ }^{517}$ MOREIRA NETO, 2001b, p. 37-38.

${ }^{518}$ DI PIETRO, 2008, p. 14.
} 
Nesse sentido, os contratos, convênios e consórcios, no âmbito das relações internas ao Poder Público, apresentam-se como verdadeiros instrumentos dessa gestão associada. $^{519}$

Os consórcios públicos receberam, entre nós, um novo tratamento normativo, voltado a reforçar a cooperação que sempre esteve presente no instituto, funcionando assim como marco legislativo irradiador de estabilidade e segurança às administrações interessadas, embora não sem proporcionar alguns embaraços jurídicos.

Em resposta ao desafio lançado ao final do Capítulo 2, temos que a atual formatação jurídica dos consórcios públicos compatibiliza-se, sim, com o modelo federal adotado no Brasil, em especial no tocante ao equilíbrio e à harmonia entre as unidades federadas. Mais que isso, pode-se dizer que, mesmo com todas as falhas do regramento pátrio, as inovações representaram o aguardado primeiro passo rumo a um grau de coordenação administrativa que já é realidade em diversos países.

Sempre haverá obstáculos à consecução dos objetivos consorciais, muitas vezes decorrentes das próprias contingências políticas de cada localidade, com entes federados governados por partidos políticos diferentes, defensores de pontos de vista conflitantes. ${ }^{520}$ Nesse sentido, todavia, a personalidade jurídica conferida aos consórcios tem o papel fundamental de emprestar-lhes uma administração mais autônoma, apta a enfrentar mudanças de governo e abalos políticos sem desviar dos objetivos visados.

Pode-se dizer que os consórcios públicos, embora tenham passado por uma radical transformação em seu delineamento legal, revelam-se mais do que nunca um dos principais instrumentos de atuação conjunta escorada em finalidades comuns, configurando-se como típico mecanismo de cooperação interfederativa.

No mais, só se pode aguardar o desenrolar da implementação do instituto na prática, implementação essa que, pelo singelo motivo de ser levada a efeito por seres humanos, é imprevisível, sujeitando-se em grande parte à interferência da predisposição cultural de cada um.

\footnotetext{
${ }^{519}$ CAMPOS, 2006, p. 54.

${ }^{520}$ DURÃO, 2004, p. 103.
} 
A esse respeito, convém recordar a advertência de León Duguit, que, no início do século XX, já anunciava que "tout gouvernement qui ne remplit pas sa mission, qui n'assure pas la paix par la justice, suivant la belle formule de l'ancienne France, est condamné à disparaître". 521

${ }^{521}$ DUGUIT, 1926, p. 145. Em tradução livre, "todo governo que não cumpre a sua missão, que não garante a paz por meio da justiça, segundo a bela expressão da antiga França, está condenado a desaparecer". 


\section{REFERÊNCIAS}

ABRÚCIO, Fernando Luiz; SOARES, Márcia Miranda. Redes federativas no Brasil: cooperação intermunicipal no Grande ABC. São Paulo: Fundação Konrad Adenauer, 2001. (Série Pesquisas, n. 24).

ALMEIDA, Fernanda Dias Menezes de. Competências na Constituição de 1988. 3. ed. São Paulo: Atlas, 2005.

ALMEIDA, Fernando Dias Menezes de; MEDAUAR, Odete (Coord.). Estatuto das cidades. 2. ed. São Paulo: RT, 2004.

ALVARENGA, José Eduardo de. Consórcio: a nova pessoa jurídica da administração indireta. DireitoNet. Disponível em: <http://www.direitonet.com.br/artigos/x/22/54/2254/>. Acesso em: 08 maio 2007.

ALVES, Ricardo Luiz. O Brasil é uma Federação?: alguns subsídios conceituais para a construção de um novo modelo do pacto federativo. Jus Navigandi, Teresina, v. 9, n. 771, 13 ago. 2005. Disponível em: 〈http://jus2.uol.com.br/doutrina/textoasp?id=7049>. Acesso em: 15 out. 2007.

ALVES, Vladimir. Comentários à lei dos consórcios públicos. São Paulo: Universitária de Direito, 2006.

ARAÚJO, Edmir Netto de. Curso de direito administrativo. 3. ed. São Paulo: Saraiva, 2007.

. Do negócio jurídico administrativo. São Paulo: Ltr, 1999.

ARAÚJO, Luiz Alberto David; NUNES JÚNIOR, Vidal Serrano. Curso de direito constitucional. 4. ed. São Paulo: Saraiva, 2001. 
BAPTISTA, Patrícia. A tutela da confiança legítima como limite ao exercício do poder normativo da Administração Pública: a proteção das expectativas legítimas dos cidadãos como limite à retroatividade da norma. Revista Eletrônica de Direito do Estado (REDE), Salvador: Instituto Brasileiro de Direito Público, n. 11, jul./set. 2007. Disponível em: < http://www.direitodoestado.com.br/rede.asp>. Acesso em: 14 ago. 2008.

BASTOS, Celso Ribeiro. Curso de direito administrativo. São Paulo: Celso Bastos Editor, 2002.

BERCOVICI, Gilberto. Desequilíbrios regionais: uma análise jurídico-institucional. 2000. Tese (Doutorado) - Faculdade de Direito da Universidade de São Paulo, São Paulo.

Dilemas do estado federal brasileiro. Porto Alegre: Livraria do Advogado, 2004.

BERGER, Renato; TOZZINI, Syllas. A finalidade das associações no novo Código Civil. Jus Navigandi, Teresina, v. 7, n. 66, jun. 2003. Disponível em: <http://jus2.uol.com.br/doutrina/texto.asp?id=4126>. Acesso em: 12 jan. 2008.

BLANQUER, Jean-Michel. Le projet de Constitution européenne: entre pacte fédératif et ordre constitutionnel coopératif. Revue du Droit Public et de la Science Politique en France et à l'Étranger, Paris, n. 5, p. 1275-1279, sept./oct. 2003.

BORGES, Alice González. Os consórcios públicos na sua legislação reguladora. Revista Eletrônica de Direito do Estado (REDE), Salvador: Instituto de Direito Público da Bahia, n. 3, jul./set. 2005. Disponível em: <http://www.direitodoestado.com.br $>$. Acesso em: 20 nov. 2005.

CAETANO, Marcelo. Direito constitucional. Rio de Janeiro: Forense, 1977. v. 2.

CAMPOS, Lílian Maria Salvador Guimarães. Consórcios públicos na administração pública brasileira: em busca de uma administração pública consensual. 2006. Dissertação (Mestrado) - Universidade Federal do Paraná, Curitiba: 2006. 
CANÇADO, Maria de Lourdes Flecha de Lima Xavier. Serviço público no âmbito dos consórcios públicos. In: PIRES, Maria Coeli Simões; BARBOSA, Maria Elisa Braz (Coord.). Consórcios públicos: instrumento do federalismo cooperativo. Belo Horizonte: Fórum, 2008.

CANOTILHO, José Joaquim Gomes. Direito constitucional. 6. ed. Coimbra: Almedina, 1993.

CARVALHO, André Regis. Reengenharia federativa: a questão dos consórcios intermunicipais. In: FIGUEIREDO, Carlos Maurício; NÓBREGA, Marcos. Administração pública, direito administrativo, financeiro e gestão pública: prática, inovações e polêmicas. São Paulo: RT, 2002.

CARVALHO FILHO, José dos Santos. Consórcios públicos. Rio de Janeiro: Lumen Juris, 2009.

COORDENAÇÃO de população e indicadores sociais. In: INSTITUTO BRASILEIRO DE GEOGRAFIA E ESTATÍSTICA (IBGE). Perfil dos municípios brasileiros: gestão pública 2005. Rio de Janeiro, 2006.2 Disponível em: 〈http://www.ibge.gov.br/home/estatistica/economia/perfilmunic/2005/munic2005.pdf $>$. Acesso em: 11 nov. 2008.

COSTA, Alex de. The corporations law and cooperative federalism after the Queen vs. Hughes. The Sydney Law Review, Sydney, v. 22, n. 3, p. 451-467, Sept. 2000.

CRETELLA JÚNIOR, José. Dos atos administrativos especiais. 2. ed. Rio de Janeiro: Forense, 1998.

. Direito administrativo municipal. 2. ed. Rio de Janeiro: Forense, 1981.

. Tratado de direito administrativo. 2. ed. Rio de Janeiro: Forense, 2003. v. 3. 
CUSTÓDIO FILHO, Ubirajara. As competências do Município na Constituição Federal de 1988. São Paulo: Celso Bastos Editor, 2000.

DALLARI, Adilson Abreu; FERRAZ, Sérgio (Coord.). Estatuto da Cidade. São Paulo: Sociedade Brasileira de Direito Público: Malheiros Editores, 2002.

DALLARI, Dalmo de Abreu. Parecer sobre a proposta legislativa de criação de consórcios públicos. Disponível em: < $\underline{\text { http://www.planalto.gov.br/ }}$ CCIVIL_03/revista/Rev_72/pareceres/consorcio_DalmoAbreuDallari.pdf > . Acesso em: 14 nov. 2005.

DEO, Marta Luiza Reimão de. Contratos, convênios e consórcios na prática da administração pública brasileira: paralelo. EDP: Estudos de Direito Público, São Paulo, v. 5, n. 9, p. 69-92, jul./dez. 1986.

DEVOLVÉ, Pierre; VEDEL, Georges. Droit administratif. 11. ed. Paris: Presses Universitaires de France, 1990.

DI PIETRO, Maria Sylvia Zanella. O consórcio público na Lei $\mathrm{N}^{\circ}$ 11.107, de 6.4.05. Boletim de Direito Administrativo, São Paulo, v. 21, n. 11, p. 1220-1228, nov. 2005a.

. Os consórcios e os convênios como instrumentos de gestão. In: ENCONTRO NACIONAL DE PROCURADORES MUNICIPAIS, 24.: 1999: Porto Alegre. [Anais]. Porto Alegre: Instituto Brasileiro de Direito Municipal: Prefeitura do Porto Alegre, 1999. p. $119-125$.

Direito administrativo. 18. ed. São Paulo: Atlas, 2005b.

. Direito administrativo. 20. ed. São Paulo: Atlas, 2006.

. Parcerias na administração pública. 6. ed. São Paulo: Atlas, 2008. 
DIAS, Solange Gonçalves. Possibilidades jurídico-institucionais dos consórcios públicos. 2006. Tese (Doutorado) - Faculdade de Direito da Universidade de São Paulo, São Paulo.

DROMI, José Roberto. Derecho administrativo. 5. ed. Buenos Aires: Ediciones Ciudad Argentina, 1996.

DUGUIT, León. Leçons de droit public général. 2. ed. Paris: E. de Boccard, 1926.

DURÃO, Pedro. Convênios e consórcios administrativos: gestão, teoria e prática. Curitiba: Juruá, 2004.

ENTRENA CUESTA, Rafael. Consideraciones sobre la teoría general de los contratos de la administración. Revista de Administración Pública, Madrid, n. 24, p. 39-74, 1957.

FALCÃO, Alcino Pinto. Aspectos da cooperação horizontal no federalismo. Revista de Direito Público, São Paulo, v. 7, n. 33, p. 23-30, 1974.

FARIA, Edimur Ferreira de. Curso de direito administrativo positivo. 6. ed. Belo Horizonte: Del Rey, 2007.

FERRARI, Regina Maria Macedo Nery. Direito municipal. 2. ed. São Paulo: RT, 2005.

FERRAZ, Luciano. Parceria público-público: contrato de programa e execução de serviços públicos municipais por entidade da administração indireta estadual. Revista Eletrônica de Direito Administrativo Econômico, Salvador: Instituto de Direito Público da Bahia, n. 10, maio/jul. 2007. Disponível em: <http://www.direitodoestado.com.br/redae.asp >. Acesso em: 14 dez. 2007.

FERREIRA FILHO, Manoel Gonçalves. Comentários à Constituição brasileira de 1988. São Paulo: Saraiva, 1990. v. 1. 
Curso de direito constitucional. 25. ed. São Paulo: Saraiva, 1999.

FIGUEIREDO, Lúcia Valle. Curso de direito administrativo. 6. ed. São Paulo: Malheiros Editores, 2003.

GARCÍA de ENTERRÍA, Eduardo; FERNÁNDEZ, Tomás-Ramón. Curso de derecho administrativo. 8. ed. Madrid: Civitas, 1997. v. 1.

GARRIDO FALLA, Fernando. Tratado de derecho administrativo. 10. ed. Madrid: Tecnos, 1989. v. 2.

GASPARINI, Diógenes. Direito administrativo. 11. ed. São Paulo: Saraiva, 2006.

GIANNINI, Massimo Severo. Diritto amministrativo. 3. ed. Milano: A. Giuffrè, 1993.

GRAU, Eros Roberto. A ordem econômica na Constituição de 1988. 7. ed. São Paulo: Malheiros Editores, 2002.

GRESS, Franz. Interstate cooperation and territorial representation in intermestic politics. Publius: the Journal of Federalism, Easton, v. 26, n. 1, p. 53-71, 1996.

GROTTI, Dinorá Adelaide Musetti. O serviço público e a Constituição brasileira de 1988. São Paulo: Malheiros Editores, 2003.

GUERRA, Rafael. Projeto de lei: consórcios públicos. Brasília: Câmara dos Deputados, Centro de Documentação e Informação, 1999.

HARGER, Marcelo. Consórcios públicos na Lei $n .^{\circ}$ 11.107/05. Belo Horizonte: Fórum, 2007.

HORTA, Raul Machado. Reconstrução do federalismo brasileiro. Revista de Direito Público, São Paulo, n. 64, p. 15-29, out./dez. 1982. 
Tendências atuais da federação brasileira. Cadernos de Direito Constitucional e Ciência Política, São Paulo, v. 4, n. 16, p. 7-19, jul./set. 1996.

HORVATH, Estevão; OLIVEIRA, Regis Fernandes de. Manual de direito financeiro. 3. ed. São Paulo: RT, 2000.

JÈZE, Gaston. Principios generales del derecho administrativo. Buenos Aires: Depalma, 1949. v. 2.

JUSTEN FILHO, Marçal. Comentários à Lei de licitações e contratos administrativos. 11. ed. São Paulo: Dialética, 2005a.

Curso de direito administrativo. São Paulo: Saraiva, 2005b.

Novos sujeitos na administração pública: os consórcios públicos criados pela Lei Federal n. ${ }^{\circ}$ 11.107. In: OSÓRIO, Fábio Medina; SOUTO, Marcos Juruena Vilela (Coord.). Direito administrativo: estudos em homenagem a Diogo de Figueiredo Moreira Neto. Rio de Janeiro: Lumen Juris, 2006.

. Parecer elaborado sobre a proposta legislativa de criação de consórcios públicos. Revista Eletrônica de Direito do Estado (REDE), Salvador: Instituto de Direito Público da Bahia, n. 3, jul./set. 2005c. Disponível em: 〈http://www.direitodoestado.com.br $>$. Acesso em: 14 nov. 2005.

_. Teoria geral das concessões de serviço público. São Paulo: Dialética, 2003.

LIMA, Ruy Cirne. Princípios de direito administrativo brasileiro. 3. ed. Porto Alegre, Livraria Sulina, 1954. 
LOVATO, Luiz Gustavo. Federalismo e federalismo fiscal: controvérsias sobre o sistema brasileiro de desenvolvimento regional. Jus Navigandi, Teresina, 31 mar. 2006. Disponível em: 〈http://jus2.uol.com.br/doutrina/textoasp?id=8179>. Acesso em: 15 out. 2007.

MÂNICA, Fernando Borges; OLIVEIRA, Gustavo Justino de. Organizações da sociedade civil de interesse público: termo de parceria e licitação. Fórum Administrativo - Direito Público, Belo Horizonte, v. 5, n. 49, p. 5225-5237, mar. 2005.

MARQUES NETO, Floriano Peixoto de Azevedo. Os consórcios públicos. Revista Eletrônica de Direito do Estado (REDE), Salvador: Instituto de Direito Público da Bahia, n. 3, jul./set. 2005a. Disponível em: 〈http://www.direitodoestado.com.br >. Acesso em: 14 nov. 2005.

- Outorga de concessão de serviços de limpeza urbana por consórcio intermunicipal. BDA - Boletim de Direito Administrativo, São Paulo, v. 13, n. 10, p. 681687, out. 1997.

_. Parecer sobre a proposta legislativa de criação de consórcios públicos. Disponível em: <http://www.planalto.com.br/ CCIVIL_03/revista/Rev_72/pareceres/consorcio_FlorianoAzevedo.pdf $>$. Acesso em: 14 nov. $2005 b$.

MAXIMILIANO, Carlos. Hermenêutica e aplicação do direito. 14. ed. Rio de Janeiro: Forense, 1994.

MEDAUAR, Odete. Convênios e consórcios administrativos. BDA - Boletim de Direito Administrativo, São Paulo, v. 11, n. 8, p. 451-461, ago. 1995.

Direito administrativo moderno. 5. ed. São Paulo: Revista dos Tribunais, 2001.

MEDAUAR, Odete (Org.). Coletânea de legislação administrativa. 5. ed. São Paulo: Revista dos Tribunais, 2005. 
; OLIVEIRA, Gustavo Justino de. Consórcios públicos: comentários à Lei 11.107/2005. São Paulo: RT, 2006.

MEIRELLES, Hely Lopes. Direito administrativo brasileiro. 28. ed. São Paulo: Malheiros, 2003.

Direito municipal brasileiro. 14. ed. São Paulo: Malheiros, 2006.

MELlO, Celso Antônio Bandeira de. Curso de direito administrativo. 21. ed. São Paulo: Malheiros Editores, 2006.

Interesse público primário e secundário: convênio entre União e Estado, dever de indenização (parecer). Revista de Direito Público, São Paulo, n. 75, p. 55-61, jul./set. 1985.

MORAES, Alexandre de. Direito constitucional. 12. ed. São Paulo: Atlas, 2002.

MOREIRA NETO, Diogo de Figueiredo. Coordenação gerencial na administração pública. Revista de Direito Administrativo, Rio de Janeiro, n. 214, p. 35-53, out./dez. 1998.

Curso de direito administrativo. 12. ed. Rio de Janeiro: Forense, 2001a.

. Mutações do direito administrativo. 2. ed. Rio de Janeiro: Renovar, $2001 \mathrm{~b}$.

MOREIRA, Vital. Administração autónoma e associações públicas. Coimbra: Coimbra Ed., 1997.

MUNICIPAL cooperation guide: MRSC Report, n. 27, Sept. 1993. Washington: Cooperation Guide Research and Services Center of Washington, Intergovernmental Agreements, $1993 . \quad$ Disponível em: <http://www.mrsc.org/Subjects/Planning/intrgov.aspx >. Acesso em: 22 out. 2007. 
PAULO, Vicente; ALEXANDRINO, Marcelo. Direito administrativo. 12. ed. Rio de Janeiro: Impetus, 2006.

PEREIRA, Luiz Carlos Bresser. Exposição no Senado sobre a Reforma da Administração. Cadernos MARE da Reforma do Estado, Brasília: Ministério da Administração Federal e Reforma do Estado, v. 3, 1997. 42 p.

PORTO NETO, Benedicto. Parecer sobre a proposta legislativa de criação de consórcios públicos. Disponível $\quad$ em: CCIVIL_03/revista/Rev_72/pareceres/consorcio_BenedictoPortoNeto.pdf > . Acesso em: 14 nov. 2005.

RAMOS, Dircêo Torrecillas. O federalismo assimétrico. 2. ed. Rio de Janeiro: Forense, 2000.

RANIERI, Nina Beatriz Stocco. Federalismo cooperativo e garantia de padrão de qualidade de ensino: o caso dos estabelecimentos de educação infantil jurisdicionados ao sistema escolar do Estado de São Paulo. Revista da Faculdade de Direito da Universidade de São Paulo, São Paulo, v. 98, p. 359-378, 2003.

REALE, Miguel. Parecer sobre consórcios públicos. Disponível em: <http://www.miguelreale.com.br>. Acesso em: 22 out. 2005.

RODRIGUES, Nina Trícia Disconzi. Novos rumos para o federalismo: contribuições para a sua melhoria. 2007. Tese (Doutorado) - Faculdade de Direito da Universidade de São Paulo, São Paulo.

RODRÍGUEZ de SANTIAGO, José María. Los convenios entre administraciones públicas. Madrid: Marcial Pons, 1997. 
SILVA, Cleber Demétrio Oliveira da. Considerações sobre a futura regulamentação da lei geral dos consórcios públicos. Disponível em: 〈http://www.rzoconsultoria.com.br/artigo_desc.php?id=17>. Acesso em: $14 \mathrm{dez} .2007$.

. O consórcio intermunicipal de saúde e a contratação de agentes comunitários de saúde (ACS). Jus Navigandi, Teresina, v. 10, n. 1004, 01 abr. 2006. Disponível em: $\langle$ http://jus2.uol.com.br/doutrina/texto.asp?id=8182〉. Acesso em: 08 maio 2007.

. Lei n. ${ }^{\circ}$ 11.107/05: marco regulatório dos consórcios públicos brasileiros. Jus Navigandi, Teresina, v. 9, n. 705, 2005a. Disponível em: $<$ http://www1.jus.com.br/doutrina/texto.asp?id=6872 >. Acesso em 25 nov. 2005. . A regulamentação dos consórcios públicos à luz do projeto de lei n. ${ }^{\circ} 3.884 / 2004$. Disponível em: 〈http:|lwww.ampcon.org.br/doutrina.htm〉. Acesso em: 14 dez. 2007.

A simetria conceitual existente entre a teoria de justiça de John Rawls e os consórcios públicos. Jus Navigandi, Teresina, v. 9, n. 816, set. 2005b. Disponível em: $\langle$ http://jus2.uol.com.br/doutrina/texto.asp?id=7344>. Acesso em: 24 nov. 2005.

SILVA, José Afonso da. Curso de direito constitucional positivo. 25. ed. São Paulo: Malheiros Editores, 2005.

SOARES, Ana Paula Macedo. Consórcio intermunicipal de Saúde: Fundação Perseu Abramo. Disponível em: $\langle$ http://www2.fpa.org.br/portal/modules/news/article.php?storyid=2606 $>$. Acesso em: 11 nov. 2008.

SUNDFELD, Carlos Ari (Coord.). Direito administrativo econômico. São Paulo: Sociedade Brasileira de Direito Público: Malheiros Editores, 2000. 
SZKLAROWSKY, Leon Frejda. Os convênios administrativos, convênio, consórcio administrativo, Constituição Federal, Dec-lei 2.300/86 e legislação pertinente. Revista dos Tribunais, São Paulo, v. 80, n. 669, p. 39-46, jul. 1991.

Convênios, consórcios administrativos, ajustes e outros instrumentos congêneres. Revista do Instituto dos Advogados de São Paulo, São Paulo, v. 2, n. 3, p. 107-112, jan./jun. 1999.

TAVARES, André Ramos. Curso de direito constitucional. 2. ed. São Paulo: Saraiva, 2003.

ZIMMERMAN, Joseph F. National State Relations: cooperative federalism in the twentieth century. Publius: the Journal of Federalism, Easton, v. 31, n. 2, p. 15-30, 2001. 